

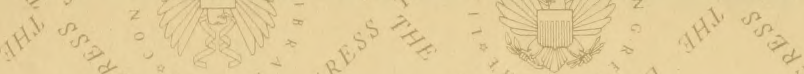
$\mathrm{APOP}^{2}$,

난?

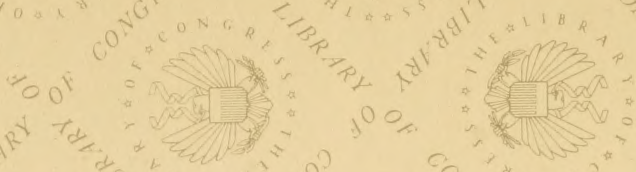

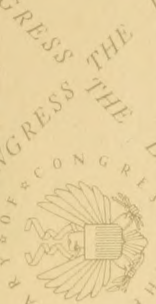
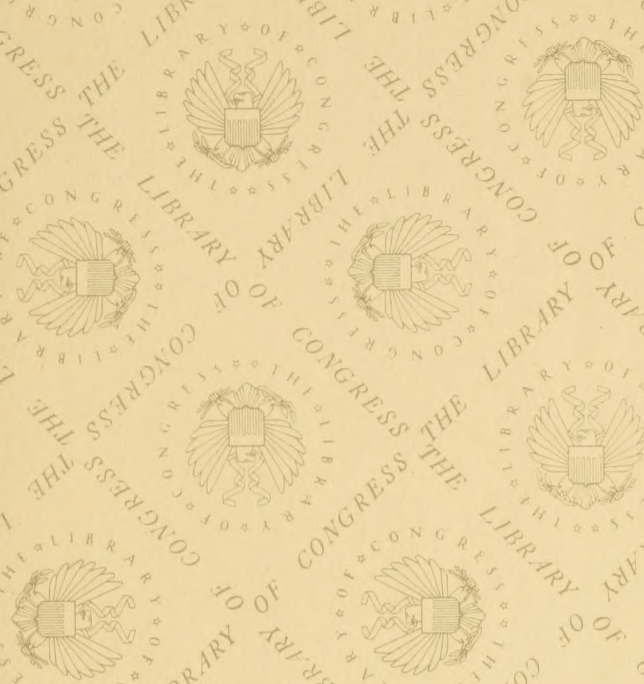

100

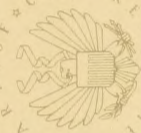

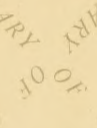
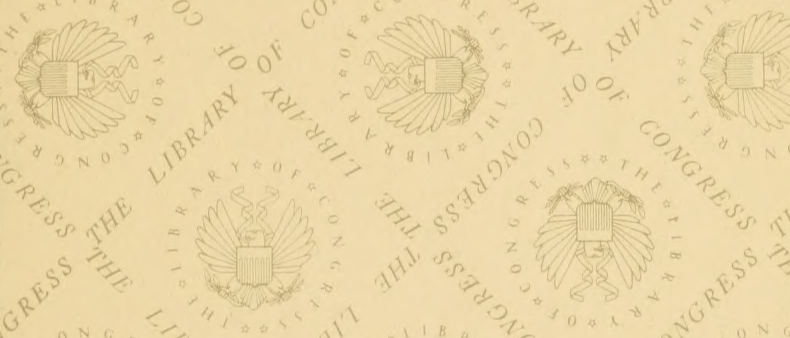

at of

कर्या है।

is. $x^{-10}$

100 ,

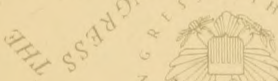

(1) क क

-

$=$
$=8$
28

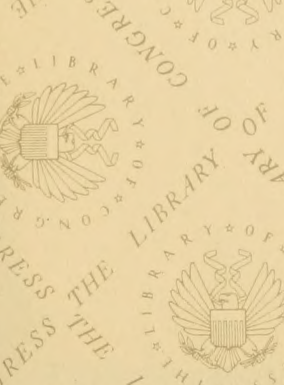

$0^{\circ}=$
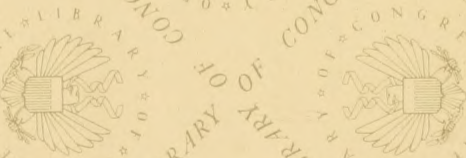

$100 x$
$=B^{2}{ }^{2}+\frac{1}{2}$

"०o

(1) ${ }^{2}{ }^{1 / 2}$

96 ㄱ.

(2)
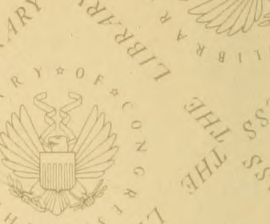

a) के

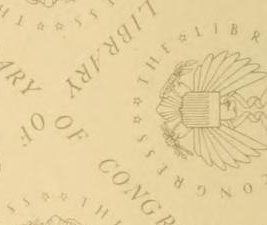

$\frac{x}{4}$

is $x$

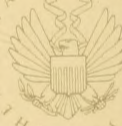

$0^{\circ}+4$

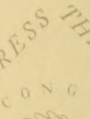

$=9+\frac{1}{6}$

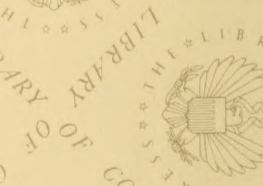
$\mathrm{O}_{2}$

(i) ह

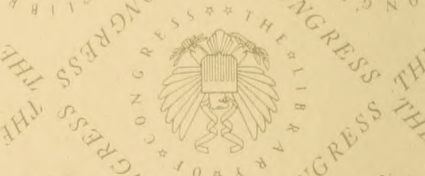

t.

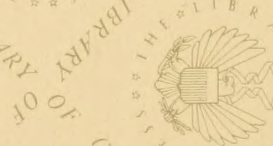

,

$1 / 001$
$1^{2}$

$\mathrm{C}^{\circ}$ 
(1)

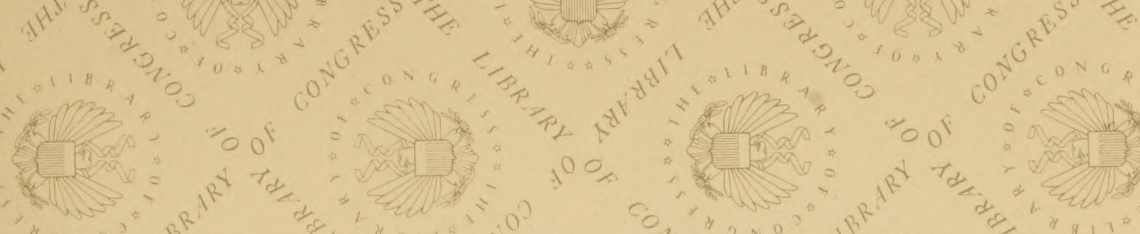

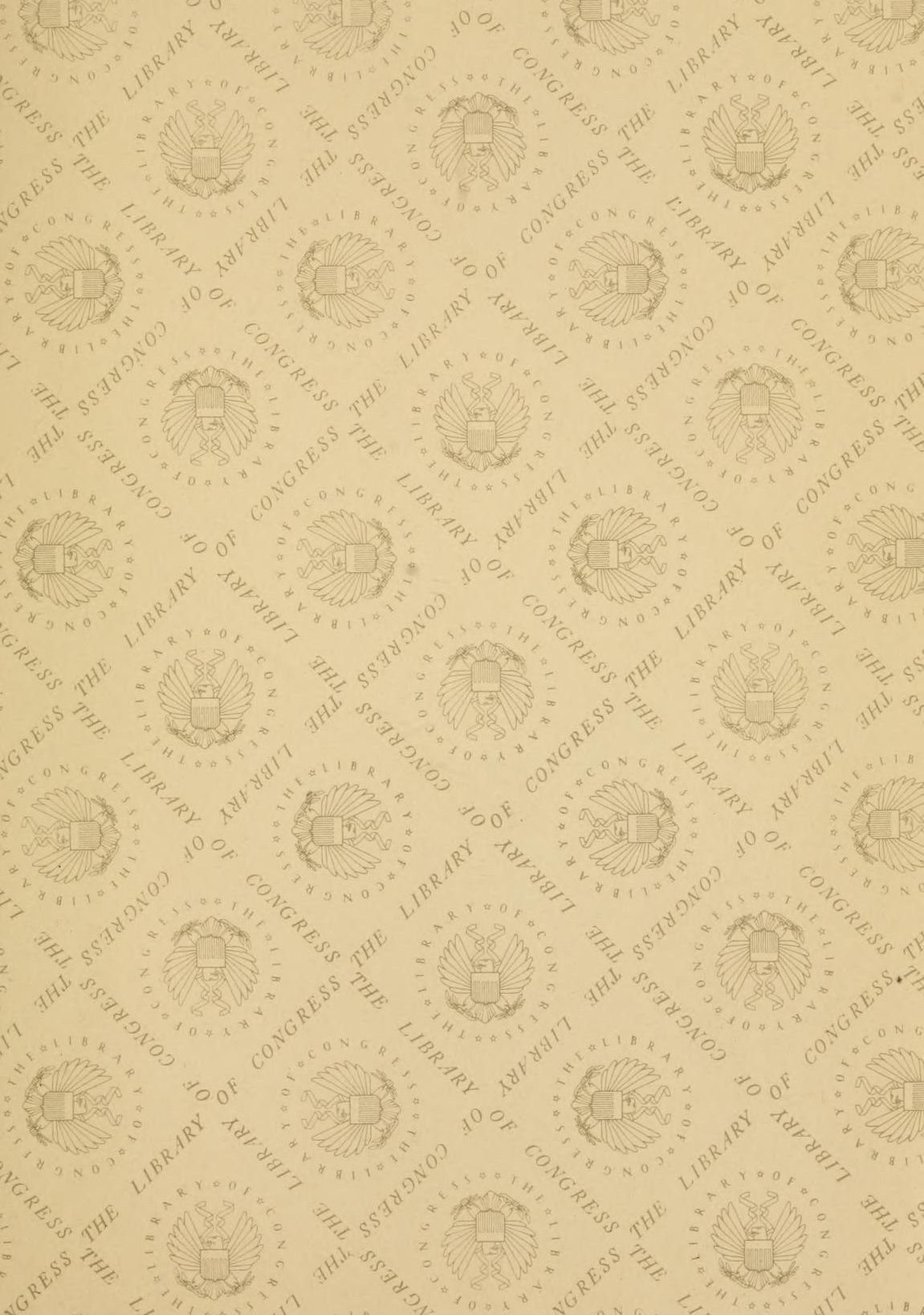





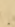

. 



\section{SPORTING SKETCHES}




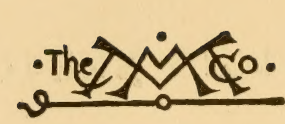





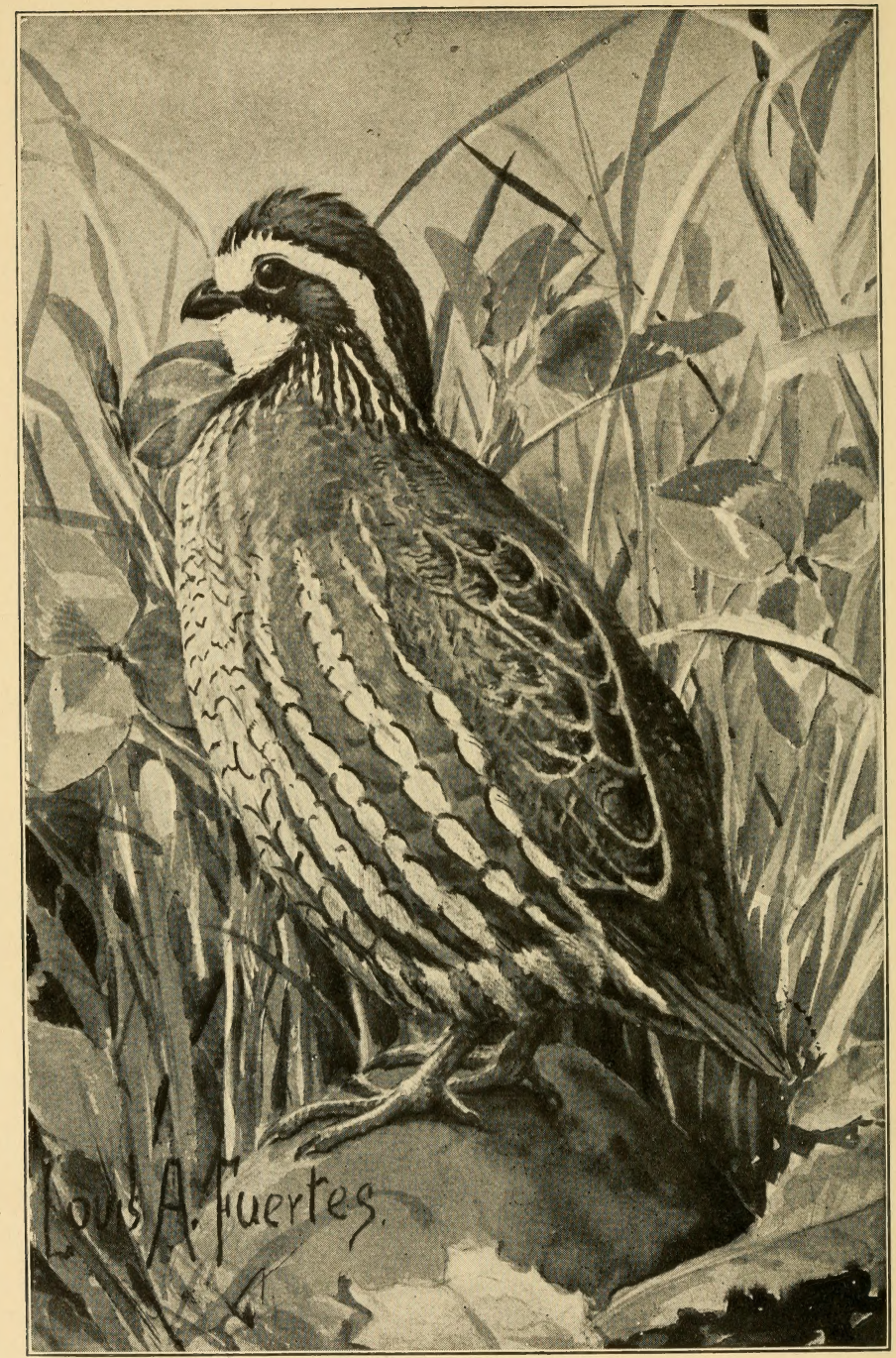

BRAVE BROWN BOB 


\section{SPORTING SKETCHES}

BY

EDWYN SANDYS

AUTHOR OF "UPLAND GAME BIRDS," "TRAPPER

'JIM,", "SPORTSMAN 'JOE,'" ETC.

J

THE MACMILLAN COMPANY

LONDON : MACMILLAN \& CO., LTD.

1905

All rights reserved 


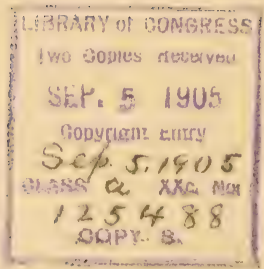

Copyright, rgo5,

By THE MACMILLAN COMPANY.

Set up and electrotyped. Published September, 1905.

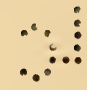




\section{CONTENTS}

CHAPTER

PAGE

I. ThE Witchery OF WA-WA . • • • . I

II. With aND against the Grains . • • • I8

III. The Wizard of the Wetlands • • • 38

1V. BEACH-COMBERS • . . . . . . . 55

V. A BIT OF RIVER. . . . . . . . . 68

VI. The Fishing of The FreE FolK • • • • $8_{3}$

VII. The Fishes of OUR Boyhood • • • • $\quad .98$

VIII. Some Truths about Trouting • • • . II5

IX. The Best of The Bass . . . . . . I26

X. A Matter of Mascalonge . . . . . 142

XI. A Bit of Sea Fishing • • • • • . I 55

XII. RaIl AND ReEd BIRD . . . . , . I63

XIII. A DAY With THE WoOdcock • • • • 173

XIV. Bluefish and Blue Waters • • • • . 187

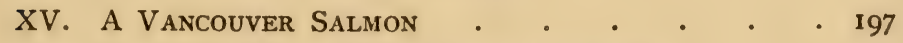

XVI. WoOd-DUCK AND Wood-DUCK Shooting • • . 205

XVII. A RED-LETTER DAY • . • . • • . 22 I

XVIII. Picked from the Prairie Province • • 233

XIX. The Conversion of Trapper Lewis . . . 260

XX. FOUR OF A KIND . . . . . . . 274

XXI. The Ruffed Grouse and Grouse Shooting • . 284

XXII. ROBERT WhIte, JR. . • • • • • 300 
XXIII. A SKIRMish With SQUirRels . . . . . 317

XXIV. TURKeY - With Thanksgiving . . . 33 I

XXV. A Cold Trall . • . . . . . . $34 \mathrm{I}$

XXVI. The White Wolf of the North • • 354

XXVII. In the Haunts of the HaRe . . . 364

XXViII. Fishing through the ICE.$\quad \cdot \quad \cdot \quad 379$ 
Many of these sporting sketches originally appeared in Outing. For the privilege of present use I am indebted to the courtesy of that best of sporting magazines.

E. S. 



\section{SPORTING SKETCHES}





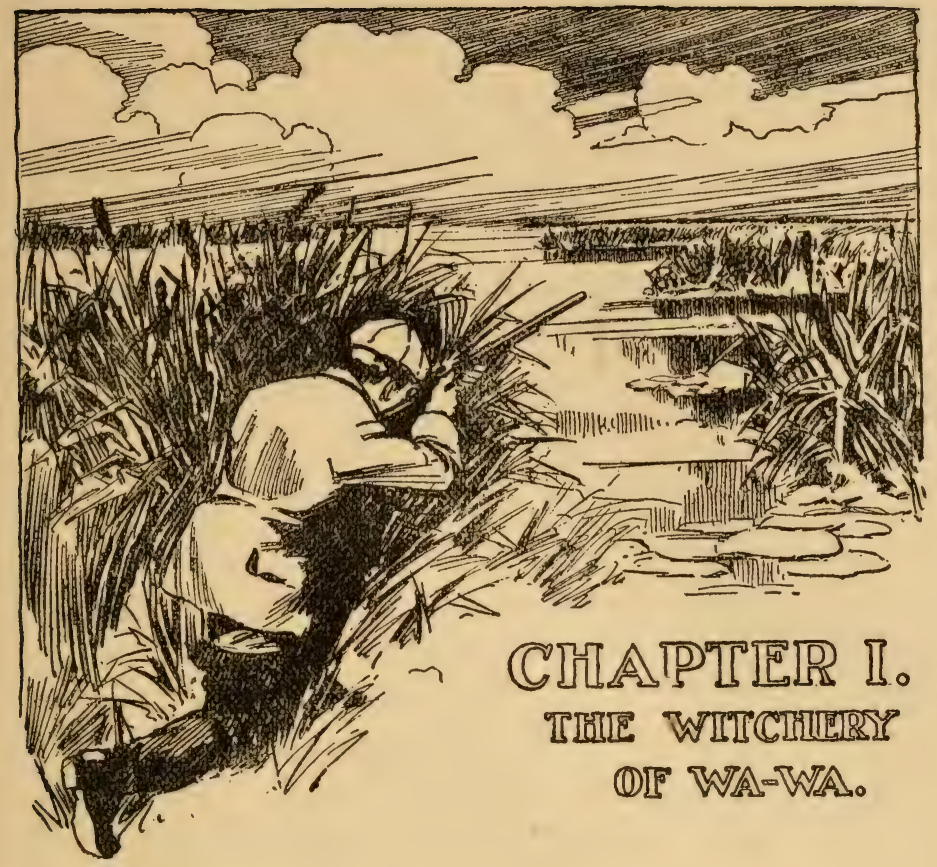

IN the North the spring comes in a day. For four long months the white paw of the Arctic bear holds everything in icy clutch. The tread of it flattens all minor growths, the iron claws of it hook into vale and ravine, and at their touch the singing waters cease their foamy play and chill and stiffen in the coldness of a deathlike trance. On stream and pond flashes the crystal breastplate of the Frost King's service. To them comes the Captain Bear. "Sleep" is the monarch's order, which the captain must enforce; so he travels far and wide, treading with creaking weight on snowy feet. His "grand rounds" mean rest, the ceasing of all strife, the temporary triumph of the forces of the North upon that bloodless field which must in turn be won and 
lost forever while the seasons roll. The ear may trace his progress by the straggling salute of smallarms from the sentinel trees, which fire and stiffen to attention; by the long, booming roll of big guns from icy plains in obedience to the order, "Salute and solidify." Upon the roof of a trout pool the bear halts. His round ear has caught the whispering giggle of water playing under the shelter of some kindly root. The keen white nose is lowered to the cavity; the "Woof!" of the blasting breath thrills the interior, and the player ceases.

Under the ice lie the trout, waiting, listening for the tread of the bear which they know will surely come. When the light above fails and the icebatteries boom, they feel his presence, and turning noses to the failing stream, they bide the issue. To them come mink and otter. Only these two can outwit the bear. They know certain unfilled rivetholes in the icy armor and its occasional flaws. Through these they slide to harry the helpless quarry.

But the bear has orders to obey. His business is to see that the Law of the North is heeded. When the rallied forces of the South again rush northward, he must slowly fall back, disputing every league of field until the last furious charge drives him to the berg-piled, impregnable stronghold of his king.

Over the war-worn field stream the restored folk, singing and making merry. But not far from its southern rim they halt, half afraid, as the signs of recent conflict are yet too fresh for timid hearts. They halt and peer this way and that. "Is it a 
trick? Has the White Bear really gone north?" ask the little people.

"He has! He has!" shouts the prideful, loudvoiced stream. "I have defeated him - see me hurl his broken bonds to crashing confusion!"

"Cheer-up — cheer-up — he's-away-in-defeat-in-defeat!" chortles a fat robin.

"Luck-y-thing - luck-y-thing!" adds a glistening grackle, lightly clashing his cymbals. "He-e-e? Gone to sea!" flutes a redwing. "May-bee - maybee," mutters a flycatcher. "I-think-think-think-hehas-gone-to-sea," trills a modest sparrow.

"Wrong! - all-wrong! — Cranks! - all-wrong!" suddenly shouts a mighty voice; and behold! the great gray goose, captain of all Northern raids the war-worn Wa-Wa. Wizard of wastes of sea and land, pioneer of prospecting poleward; better than all he knows the shift of season and the northward mystery. His scoutings have extended to the last wan berg, and his trumpet has thrilled the remotest corner of the White Bear's den. Like most great captains, he is curt, while loud of speech.

"Tarry awhile," he says; "if within two weeks I come not back, then for-'ard all!" Through his brazen trumpet he blares a thrilling order, and prompt and silent his gray-clad troop falls in. "En avant!" The clang of it stirs the blood of all, for each has heard the tongue in old Quebec and in the farther wastes, and the sound of it recalls the joys of sweet new pasturage, of love-making, and happy summer homes in Daylight Land.

"En avant!" Like the head of a mighty arrow shot poleward, the drilled battalion hisses through 
the cold, thin upper air. Wa-Wa himself is leading, for none other so well understands how best to wedge opposing airs, or when to rise above, or to dip below quarrelling winds. He also best knows the route, for he has been over it, to and fro, each spring and fall; ever since that wonderful first autumn when his parents shepherded him and his brothers and sisters from Arctic meadows down to the lazy, locked lagoons of the South.

"En avant!" He loves to give that order. For many years he has set the pace, yet each succeeding season has found him keener for the northward flight. He may dawdle when southward bound, but going north is different. Then he always follows the old trail, stooping to this plain and that lake, and tarrying only for food and rest, or while temporarily storm-bound, until he reaches a certain point. From this he bears west-by-north until the forest dwindles and below him spread two big lakes with a little lake between. Into this little lake runs a big river and out of it runs another big river. The little lake is ringed with marshes, beyond which, upon one side, lie leagues of level fat-lands, squared with withered corn and the green of winter wheat. Here he always halts for rest and refreshments. He may stay a week or a month. It matters not, for it is the loveliest spot, save one, along the route. The other spot is his birthplace, away up in a Manitoba muskeg. Its real merit is its privacy, - otherwise it is a rotten bad place, - but then everybody knows what a goose a goose is apt to be over goose affairs!

Wa-Wa has another and a private reason for halting by the little lake. Years ago, during his 
third visit, he was leading his battalion in to feed at gray dawn, when a long-legged, lathy-looking, brownfaced boy suddenly rose from a pile of corn-fodder and shot at him. Wa-Wa felt something hot slice across his breast, and for a moment his strong flight wavered. Then he recovered himself, and, shouting defiance at his foe's single-barrel, he led his honking troop five miles away to a safer ground. But before departing he took a good look at his enemy, and the mental picture never faded. The long, lean figure, the smooth, swart face, the black hair, and the great, staring eyes were unmistakable, and Wa-Wa vowed to get even or, as he put it, "hunk!"

For weeks the wound bothered him, but at last it healed. Yet the mark of it remained. Whenever Wa-Wa reared his long body upright and bent his snaky black neck to arrange his lower plumage, he saw a snow-white streak amid his dressy gray. And every time he saw it his eyes would gleam and he'd hiss savagely and snap at the grass.

"Why do you brood over it, dear? That miserable boy is not worth remembering," his wife would say. In her heart she was rather proud of Wa-Wa's badge of having been in action, and she almost wished that the shot could have raked both sides alike, for a white line on both sides would have been so dressy and so different from anything worn by any of the other ganders. She used to declare that she loved to stand upon Wa-Wa's left, for then the white line exactly matched the crescent-shaped white cravat which she always wore. She never said so much to Wa-Wa but once. That time he looked at her with a perfectly horrible stare - then 
waddled off, hissing until he found a couple of the toughest old ganders on the grounds.

When next he led his followers to the little lake, he changed his tactics. All pitched in the open lake, and after they had "washed-up" and become eager for young wheat, Wa-Wa ordered them to stop where they were, while he flew in to spy out the land. They were somewhat astonished, but no goose ever disobeys; so they waited, wondering what new wrinkle was bothering their wise old leader.

Wa-Wa flew slowly in, keeping one hundred yards above the wet fields and carefully scanning every yard of possible cover. The sun was just rising, and the first ray to touch the ambush of the last year waked a flare of red and a dazzling white flash. Wa-Wa well knew that a human face in such light shows very red, and that a gun-barrel flashes white. A few seconds later he almost screamed with rage, for there lay his foe-eyes, hair, long figure, and all. Slowly and steadily Wa-Wa drifted in, till he saw his foe spring to his knees. Then Wa-Wa climbed straight up, as he well knew how to do. A double report sounded dully from below, but nothing happened. "He can shoot twice now," thought Wa-Wa, as he swung wide. Then he shouted as loudly as he could, "Hunk! - gethunk-hunk!" and bore away to his friends, whom he led to a point some three hundred yards from the danger zone. Telling a trusty young gander to keep a keen watch upon the skulker, Wa-Wa hastily fed, then relieved his sentry. Slim-necked, erect, and tall, he stood, his small, angry eyes never shift- 
ing from his foe. Finally, after all had fed, he gave the order to rise as straight up as possible and to follow him. In a grand, sweeping curve he led them till they were directly over the foe. Two puffs of smoke sprang upward and a spatter of harmless stuff touched a few flight feathers.

"Mark him well - never nearer!" ordered Wa-Wa, and his merry troop chattered back a jesting assent. Then Wa-Wa twisted his neck downward and roared, "Hunk!-get-hunk-hunk!"

Day after day Wa-Wa played his game of coming in alone and spying till he had located the peril, then leading his troop as closely as he dared, until the smoke leaped up. The last morning of his stay was so warm that the troop was lazy and wanted to fly low. Wa-Wa, however, had a surprise for them as a result of his scouting. His first glance over the wheatfield where they fed had detected a disturbed spot. Passing high over this, he saw the upturned brown face and fierce eyes he knew so well. Without a sign of recognition he went back to his troop, explained the novel trap, and then led the way directly over it. Again the twin puffs of smoke sprang up, and Wa-Wa, almost stopping, shouted directly into the barrel, "Hunk! - get - hunk - hunk!" That night he led the way northward.

The next spring came, and with it Wa-Wa and his new troop. Again he warily scouted, but for a time, search as he might, he could not uncover the ambush which he felt was somewhere below. The spot where the barrel had been he distinctly recalled - the wheat was there as usual, but the barrel was not. The only thing worthy of notice 
was a small, thin fringe of dried weeds, which marked a spot where the wheat had failed. Twice Wa-Wa looked at it, then suddenly he remembered that snow always flattens such weeds - indeed, all other weeds lay flat. Then his marvellous eye made out the dim outline of a prone figure, which so closely matched the scant cover that no other gander would ever have noticed it. For a moment Wa-Wa was almost frightened. There was something so devilishly crafty about the thing that the bare idea of it made him shudder as he swung slowly around it at a safe distance. Presently he detected the slightest of movements and then a glint of red. Instantly his wrath blazed hotly, for there were the well-remembered hated eyes, fairly flaming with savage eagerness.

Back to the troop went Wa-Wa. Every member had been told what to expect when they reached the place - indeed, the story of Wa-Wa's enemy had been honked and hawked from mouth to mouth from the Arctic to the South. After explaining the situation, Wa-Wa led the way directly over the weeds. Once again the expected smoke arose, but this time the shower of stuff pattered smartly - so smartly that one young girl of a goose yelled "Ker-ouch!" as loud as she could. Bidding the rest go on, Wa-Wa circled and again passed over the weeds. To his amazement, two more puffs of smoke belched up and something whizzed mighty close to his head. "He can shoot more times and farther now," thought $\mathrm{Wa}-\mathrm{Wa}$, and with the thought came a decidedly uncomfortable feeling. The next instant he was furious, and he fairly screamed his farewell, "Hunk! 
-get-hunk-hunk!" Then he rejoined the troop and led the way to a field fully a mile distant.

"My dear," said his wife, that evening, as they rocked side by side on the baby waves of the little lake, "I don't wish to bother you, or to meddle in any way, yet I would like to ask you a straight question, What's wrong with you to-day?"

By way of answer Wa-Wa hissed savagely and drove his snaky head into a curling ripple. Then he said, "There's nothing particular the matter you wouldn't understand if I told you."

"But, my dear!" she persisted, "there is something the matter. You can't fool me - I know you too well. You're crusty and worried - and - and -I believe-it's-all-about-that-man-in-the-field - sothere!"

Wa-Wa hissed again and his small eyes blazed with fury, but beyond a low rattle in his throat he made no immediate answer.

"Don't act so," she continued; "it's unlike you. Besides, I've really got to speak to you - it's been on my mind to do so for some time; but you've led us so long and so well, dear, that it almost breaks my heart to say it, but I must! Look out for that man - he'll do you an injury yet. Can't you see that he comes nearer and nearer to doing it every time? Why! that last time almost lamed Gozzie's wing. It hurt the child and frightened her half to death - and - you know, dear, such a thing never happened before. I was thinking that p-e-r-h-a-p-s we might go to some other place - say the other plains - they're just as convenient, and it would 
be a pleasant change - the children have never been there, you know, dear, and - "

"For wheat's sake, shut up and don't meddle! You can honk faster than any goose I ever saw!" roared Wa-Wa, and the wife drifted a yard away, for this was the first time he had showed real temper to her.

He was angry, too, for the old gander is lord of the lot and never tolerates the slightest interference. But back of it all lay an uneasy feeling - an indefinable dread, which, try as he would, he could not entirely banish. By dawn, however, he was himself again; but this time he did lead to a spot far to one side of the dangerous weeds, and where there was no cover for hundreds of yards all about. He had not troubled himself to see if the foe was in the hide; but as all hands swung lazily lakeward, he looked back and distinctly saw the hated form erect above the weeds. That very afternoon he gave the order for the North.

${ }^{*}{ }^{*}{ }^{*}{ }^{*}{ }^{*}{ }^{*}{ }^{*}{ }^{*}{ }^{*}$ world was white - white as the soul of a child. Bells jingled unceasingly, rich robes swept the snow, and big wood sleighs, laden with young fir trees, went groaning along the streets. At the window of a big house, almost buried among huge snow-laden pines, stood a winsome wee lady, looking down the straight path which led to a distant gate. The glow from a huge open fireplace played upon crimson curtains and brought the dainty figure into sharp relief. Almost childish in stature, it required a second glance to detect the tiny cap, the silver strands in the wavy black hair, and certain 
lines about the mouth which hint where Time marks up his score. She evidently was expecting somebody, and she didn't have long to wait.

As she watched, the space above the gate was suddenly filled by a hurdling figure, which flew the trifling barrier as though it were a mere print in the snow, and sped with long leaps along the path. In her excitement she rapped the big pane so hard that it flew into clashing spears; but that one pane was the only thing of that name in any way connected with that particular reunion.

"Time!-breakaway!" he managed to gasp a few moments later, and when he had got free he added solemnly, "Mater, if you persist in hugging and punching when clinched, I'll give you the heel." He towered above her as a greyhound towers above a rabbit, but the Rabbit didn't appear to mind. In fact, it showed a decided tendency to force the fighting, fouls and all, but he straightened up, which most effectually prevented the Rabbit's getting its favorite hold.

"Think of it - whew!" he presently said; "this Christmas actually ends the infernal grind, and I can loaf for a year - a whole year! if I want to." She said never a word; her face assumed a comical attempt at sternness, and she held out a wee hand.

"Um-er-yes - that's so!" he stammered, as he pretended to fumble in search of the proof that he had been actually doing a trifle of work between athletic events.

"There's the condemned thing, and I hope you'll prize it, for the cost has been frightful!" he concluded, with a forced calmness; for he felt like 
yelling, or trying a hitch-kick at the ceiling, or any old thing that would let off steam. After one swift glance, the Rabbit betrayed a sudden fierce determination to mix matters in a final rough-and-tumble, but he side-stepped and repeated his warning.

"A prize indeed!" exclaimed the Rabbit, and, with an arch look, she added: "A prize to the Lady, and a Sir-prize to the Gentleman is but fair. Won't your Majesty enter the Royal Chamber?"

"Same as ever, I s'pose?" he queried, though well he knew that nothing in that room ever was disarranged, nor would it be so long as the Rabbit bossed the burrow. "Come, let's go see!" he suddenly exclaimed, and as he spoke his long arms shot out in a way that only boxing can teach. The terrified Rabbit had been hoping for, yet dreading, this very movement; for, womanlike, at that instant, she was wondering if he had forgotten. Not a bit of it! Up in the air she rose until she was seated on his shoulder; then all she could do was to bury her small fingers in his thick hair and hang on, quivering a bit, yet glorying in his supple strength. The stairs he found easy, as of yore, and the room precisely as he had left it; but on the army cot lay a long, narrow, boxlike package.

The marks on the package told of a sea-trip, and he promptly got rid of the wrappings. "English oak - brass-bound," he muttered. "Must have cost - Why! - you - little dev-I mean darling this thing - c-c-cost a hundred pounds!"

"What of it?" philosophically remarked the Rabbit. "This thing that I got cost years of hard work!" 
To put it together and swing it a bit occupied only a few moments. Then he knew that somebody had told her the weight, stock, and drop, for these were exactly right. Who had done the telling and ordering he at once guessed, for few men have many such close friends. It was indeed a beauty, and after he had settled for it in the only coin that would pass, he suddenly exclaimed, "Mater mine, won't I do things to old scar-bel - I mean Wa-Wa - when he comes north!"

"Who's Scarbel, or Wa-Wa? - I thought 'Wa-Wa' was Indian for wild goose - Longfellow says so," quoth the Rabbit.

For a moment he was too busy pointing the gun the other way to answer, and the dainty weapon shook in a manner which suggested a vast amount of nerve-racking overstudy on his part. Then he pulled himself together and answered with preternatural gravity:-

"Anser - a goose - scarbellerificus - buckshoticus - arcticus - etcetereticus - a goose of the Arctic, remarkably hard to get. Humanum est errare," he added reflectively. "Oh!" said the Rabbit.

"Listen, Mater," he continued. "For years I've laid for a certain wise old gander on the plains. Every trick I know I have played on that old rascal. Once I hit him, but he was a bit too high - I was a poor judge of distance then. Every chance I've had since I've tried for him and failed. He knows me and I know him, but now I'm wiser. I have learned how to 'call' from a New Brunswick chap, and I can do it well. I'll make and paint a few profiles (decoys, you know), and when Wa-Wa comes, 
with the help of your superb gift - I'll get him! Really, I must get him!"

Two months later the decoys were made and painted. He knew how to paint, and he knew the birds better than most men know them. The profiles were life-size, of half-inch stuff, and dressed down to a knifelike thinness along all upper edges. Seen from directly above, they were mere sticks upon the ground, but from a distance they were geese, and when set up with one pointing to each quarter, two always were visible.

When the birds came back, he was ready, and one night he said, "By-by, little one, I'm off after Wa-Wa." Fully equipped, with the profiles knapsack-fashion, he started on the long tramp. It was the softest of spring nights. The air was shaken with the peep of hylas and the brazen ripple of frogs. The storm of it before him calmed at his passing and burst anew in his rear. For mile after mile he tramped, till the east flared redly and the breath of the huge open came to him. A pair of blue wings hissed past, and from the darkness came the hoarse queries of black duck, the clearer tone of mallard, and the querulous chatter of pintail. Once, from far away, came a faint honking, and at the sound of it he hastened.

To arrange the decoys was a simple task, but as he thrust the last support into the soft wheat-land, his ear caught a mournful "Hunk! - hunk- hunk!"

"I'll go a hundred yards below to make sure," he muttered, as he turned to look at the really excellent decoys. Where receding waters had left a stranded 
raft of dry weeds, he sat down and waited. The good old pipe kept him content, and he listened to the voices of feathered folk. Ducks of several sorts kept streaming over, heading for distant corn-fields. Then a rasping scaipe! - scaipe! caused him to nod his head knowingly. At last a flash of yellow light gleamed across the level, and black shadows trailed westward from every slight projection. Presently a distant honking, a clamor of many voices, betrayed the fact that geese had taken wing.

He twisted an old corn-tassel into the cross-strings of his cap, tossed a few weeds over the gun-barrels, then laid down and stayed down. He was dressed right and he knew it, so with chin upon hand he lay, his eyes, shadowed by the visor, fixed upon the western sky. Soon a black thread drifted into view and at the first glimpse of it his head sank lower, but his heart beat higher. On and on came the thread, changing to a cord, then to a cable, lastly to a row of big black beads.

"Hunk - get - hunk - hunk - aw - hunk!" he sung out, then snickered to himself. The brazen rasp of it was startlingly correct, and a confident repetition of it caused the flock to head directly for him. Not another sound did he utter, but he lay face down like a dead man, although muscles twitched and his heart thumped audibly. At last, from almost overhead, sounded a suspicious croak and the wiff-wiff of mighty pinions. In an instant he was upon his knees, and the new gun fairly leaped to his shoulder.

As he rose, a long line of geese wavered, parted, and the two sections fell away to either side. In 
the space left, one remained alone - a huge, thicknecked old gander, with a conspicuous white welt across his left breast. The other geese need not have worried. The trim tubes sought the white cravat not forty yards away and swung truly with it. The gander lurched, half turned, and before he could recover, the hail from the second barrel struck him full broadside. He reached the mud with a "whop!" which might have been heard for half a mile.

"Hunk-got-hunk-hunk!" chuckled the man, as he laid down the gun and started for his prize. Naught cared he for other geese-he had got hunk!

Three hours later, the little woman watching from the doorway sees again the tall figure at the gate. But such a change! no flying leap and springy stride this time, for in truth he scarce could have hurdled a match. The drawn, sweat-lined face was gray with weariness, yet the eyes still blazed with the spark of a hard-won triumph.

"Well, your gun's a beaut - here's old scar-bel - I mean Wa-Wa!" he grunted, as he suffered the great gray form to fall from his aching shoulder to the piazza.

"Ugh!" she gasped in sudden terror, for from the dead throat slipped a hollow croak - a wraith of late clarion honking.

He well knew 'twas merely air driven by the fall through the great windpipe, yet he glanced curiously at the fowl, then started slightly. As the gander lay, the body and neck were in shadow, the head in full sunlight. In that light, the small, dead eye flamed 


\section{The Witchery of Wa-Wa}

like a ruby, and seemed to stare with undying hate and defiance.

"That's funny," he muttered. "Guess old scarbel - Nothing! never mind," he hastily added in reply to her questioning glance. Then he gripped the long neck and strode away to illustrate that misquotation, "The goose hangs high." 


\section{CI几ADTIER III. WITII AND AGAINSTI TIUIE CERAIINS。}

Every style of fishing has its earnest devotees and its special claim to prominence in the minds of certain men, who are ever ready to maintain the superiority of the branch of the sport they follow.

The tarpon fisher considers himself as much above the salmon fisher as the latter holds himself above the man who bothers with sea-trout, or anything less noble than salmo salar, and who finds his wand of magic to be a single-handed rod. The slayer of acrobatic ouananiche scorns speckled trout as the true trout fisher pooh-poohs black bass; while the admirers of the big-mouthed, dusky gladiator stoutly maintain that he is boldest and best on hook or on board. So it runs downward through the list.

The fly-fisher scoffs at squidding, trolling, baitfishing, spearing, and at anything and everything, save fly-fishing, and still old "Ike" ne'er preached such a creed. There are plenty of enthusiasts who declare that trolling for bluefish in a spanking breeze, or hauling lusty sea-bass by main force from foamy breakers which soak one from sole to crown, are the only styles of fishing worth following. Others find their keenest excitement in winding a 
shark ashore with winch and chain tackle; in lolling upon a wharf and taking slimy catfish, or other ignoble prey; or even in the lawless method of exploding a dynamite cartridge under water and lazily picking up a few of many fish destroyed.

I make no attempt to decide the merits of these many opposing claims. Each supporter is partly right and partly wrong. Fishing of any kind (barring the dynamite) is good enough for me, and in my humble opinion, whatever kind fate allows one to enjoy, is, or should be, the best of all - while it lasts.

One method of fishing, almost invariably sneered at by anglers of high degree, is spring spearing; yet it frequently affords a deal of fun and requires no small measure of skill on the part of its successful votaries.

I have heard men who had no aversion to spearing through the ice rail against spring spearing as unworthy of any decent man's attention, yet they never mentioned the one good argument, i.e. that the sport encouraged the destruction of fish while on their way to the spawning beds. Undoubtedly spring spearing is not beneficial to the fish speared, nor is the killing of a roe-laden fish on her way to spawn calculated to increase the number of young fry.

But the decriers of spearing overlooked this and contented themselves with rash statements to the effect that it required no science and was merely "slopping about" anyway. The true causes of their dislike were, that the successful spearer must travel long distances over wearisome, muddy foot- 
ing; must frequently wade in cold water and think naught of a ducking, and must be able to handle his grains, or spear, for thrust or throw, as skilfully as a Zulu warrior handles his deadly assegai.

Stealing along a trout brook, or fishing from boat or punt, doesn't develop these qualities, and as the swell angler hasn't got them, perforce, in his opinion, they are no good. Be that as it may, we of the old restless, rough-and-tumble crowd learned to handle grains before we could cast a fly, and many a day's fun we enjoyed; for spearing is preëminently a sport for country boys and men.

When April's tears and smiles prevail against icy fetters and let the prisoned waters run, comes the brief spring season for the grains. On Northern waters the ice is generally rushed away to the lakes by heavy floods, which spread far over the lowlands bordering the streams. For a brief period rivers are many times their normal size; every tributary creek and streamlet is a swollen, discolored contribution to the volume of the larger streams, and every ditch is bankful or overflowed. Once the ice is carried off and the outlets are free, the great waterways lower as rapidly as they rose, and all overflows, and back-waters sweep back to the main channels. Naturally, the waters of the creeks, brooks, and ditches run clear in a short time; and while a river may be several feet above its average level and as opaque as pea soup, its tributaries may be pure and transparent as springs.

Just after the ice goes and the floods begin to subside, the "run" of fish for the spawning beds commences. Nets are put into active service in the 
turbid rivers, for clear water is not required for them; and while the fishermen haul their catches of mullet, pickerel, pike, suckers, etc., would-be grainers keep close watch upon the creeks and ditches. Soon comes the day when the bottoms of creek and ditch may be seen through swift, sparkling currents, and the word is passed round that "spearin's good."

Our favorite game was the pike - the mottled, shovel-nosed rascal, called "pickerel" in Jersey and in many other places. I do not claim that our name was correct, but it was used to distinguish the fish from its more valuable relative, the pickerel (as we called it), or dorè. The latter fish, the wall-eyed pike, "ran" in great numbers in the rivers and was taken by netting. I never saw one in the smaller streams.

Our "pike" were persistent explorers. They ran up-river in schools, and whenever they discovered the current of a creek or ditch pouring in, some of them would leave the main stream and work their way up the tributary as far as they could swim. Hence it was not unusual to find one or more big pike in a flooded furrow half a field away from a main ditch. If the water suddenly lowered, countless numbers of the fish were sure to be prisoned in ponds and water-holes, where, as all retreat was cut off, they sooner or later perished. They were given to pushing up the creeks to their sources in wet woodlands, where they would wander through shallow, amber-tinted pools for rods on either side of the channels.

Here half-submerged logs and fallen stuff afforded 
many places of concealment, and sharp eyes were necessary to discover lurking fish. If one stirred in the shallows, it was easily followed by the ripple it caused on the otherwise dead surface. The fish, as a rule, moved about in pairs, or perhaps three together, after the spawning grounds were reached, and we used to wade in search of them, examining every possible shelter and keeping our eyes open for any ripples.

Most of the town and country blacksmiths could tinker a grains with three or more barbed tines, and different styles more or less elaborate were sold by hardware dealers. We favored the three-tined pattern, as less liable to make two useless fragments out of a good fish too roughly struck. Many of the young fellows prided themselves upon their skill in throwing the grains $\grave{a}$ la spear, and a few, myself included, after breaking a tine, would file off the stump and the opposing tine and spear away like good 'uns with the centre double-barbed point.

The length of handle for the grains varied greatly. Some were fourteen to eighteen feet long and correspondingly heavy and clumsy. The "old heads " favored these and did good work with them, too, but we would have none of them. We didn't care a button for the fish secured: we, wanted sport and to throw the grains at every opportunity, so we secured handy sticks from eight to twelve feet long. To such short staffs a cord was frequently fixed to aid recovery when thrown into a broad, rapid current; but the simplest method was to throw the spear anyway, and then to walk right into the water after it, in case it could not otherwise be recovered. 
More than once I have seen a grains thrown recklessly at a fish a dozen yards from the bank of the swollen, ice-cold river, and as it floated with the current its owner would have no choice but to plunge in and secure it with as little tarrying and as few strokes as the law allowed. Whether he lost his grains by funking a frigid swim, or regained it by a fearless dash, we guyed him just the same, and his best policy was to grapple somebody whose raiment was dry and strive to get warmed up in the struggle the dry one was certain to make to get away from the damp embrace.

Among the devotees of pike spearing two methods were popular: One was to lie in wait where the clear current of an outflow joined the turbid main stream, or upon a fallen tree or bridge, and spear the fish with long-handled grains as they passed, bound upstream. This method was popular with the veterans. It was restful and not necessarily a dirty or wet procedure, and the watcher had chances at all fish that sought that stream while he was on deck. It had disadvantages, inasmuch as the run of fish was always uncertain, and a man might watch for hours in vain. All fish already past that point were lost as far as that grains was concerned; and while there was nothing doing at the outlet, there might be rare fun farther above and at the headwaters. At such ambushes the spearing could also be done at night if a fire could be built so as to cast a strong light on the water, or if the grainer had a lantern equipped with a good reflector.

The second method offered the most variety, and appealed to the restless ones. This was to follow 
the windings of the water for miles, taking mud and slop as they came, to wade when needful, to get wet and outrageously dirty as a matter of course, and to finish off with wading through the headwaters and tramping home as best one could. The shorter grains, easy to throw, were most serviceable for this work. By following the stream thoroughly, one stood a chance to find all fish that had passed up, and a miss with the grains might be rectified later on, for a missed fish was certain to go upstream, and might be overtaken and tried again if it kept to the channel.

The best costume for this method was the oldest and most useless clothes one possessed, for the man who couldn't afford to get covered with mud was safest at home. Many grainers wore long rubber waders, but the value of these was doubtful. One was almost certain to fall over or off of something ere the trip was done, and waders wet inside are an abomination. Besides, they are unpleasant things to walk across country in during a return tramp. I used to rig my feet with old stout boots, with enough cracks in them to let water run in or out at will. Any kind of ancient trousers was good enough, and a pair of strong leggins amply protected the shins. Thus equipped, I would walk into the first water I reached, to get wet and be done with it. After that it was easy to take what came, and if one slipped and fell into the mud, a wade through deep enough water fixed matters first rate.

For carrying the fish, we invariably used a longish supple switch, with a short stub left near the lower end to keep the first fish put on from slipping 
off. The switch with its fish could instantly be dropped from the left hand if occasion demanded, and there was no danger of a newly taken captive making off, for a fish removed from grains has not much music left in it.

Successful use of the grains after a fish was discovered was not so easy, despite statements from the opposition that no skill was required. Of course, almost any fool could strike a fish if it lay quiet in very shallow water. Under these conditions a rap from a club would be just as efficient as a spearthrust. But pike are not given to half stranding themselves for the accommodation of their pursuers. Fish seen lying motionless were generally at the bottom of some deep pool, or beneath some log or other shelter likely to interfere with the grains. When a man could get directly over a fish, the spearing was easy, provided the man worked cautiously and correctly estimated the depth of water. The surest way, in anything more than a foot and a half of water, was to silently dip the spear till the points were within about six inches of the quarry's shoulders. A swift jab would then be almost certain.

But woe to the man who fiddled too long, or was careless in his movements. A fish can get away from a standing start with astounding speed, and our pike is one of the sprinters of his kind. Lean, long, and slimy, he is a javelin of fishdom, and his lightning dart will baffle all but the best trained eyes.

Throwing the grains so as to strike a moving fish requires a ready arm and quick, accurate calcula- 
tion. Stationary or moving, a fish is apt to appear from four inches to a foot nearer to the surface than it actually is, the amount of refraction varying with the depth of water. The grains must, therefore, be aimed ahead of and seemingly below a moving fish to strike true. When the game is stationary and offers only a side shot, careful allowance must be made, or the points will pass above their object. I have seen a big pike run a gantlet of four spears, guarding a stretch of water perhaps ten yards wide and two feet deep. One weapon after another struck, "chug - chug — chug - chug," while a flying furrow on the surface told of a swift shape speeding unharmed below it. In this case, though we were all experienced, we miscalculated the depth of water and overshot the best fish seen that day.

A friend, son of one of the "river farmers," as we styled the owners of fat bottom-lands, had asked me to join him for a day's slopping round. I was to reach the farmhouse about evening, and we were to turn out at sunrise next morning, and try a long creek which drained an extensive tract of woodland. The mouth of this creek was near my friend's home, so I concluded to travel along the river bank till I reached the smaller stream, and to have a look at the water for myself. As the river was very high, and the going muddy, I wore long rubber waders, for I could not change clothes until I returned.

When I started on my four-mile tramp the afternoon was warm and bright, and I poked along, not caring to reach the house before supper-time. Wading through shallow overflows kept my rubbers cool 
and comfortable until I reached the mouth of the creek. Here I found the outrunning water perfectly clear, the clean current extending for a couple of yards into the roily river. It was a capital place to watch for fish, and as I had time to spare I concluded to bide a wee.

Out of spearing distance in the river, fish were running famously. The quick strikes of the pike rippled the gliding surface continuously, and now and then the reddish fin or caudal of a mullet showed where some big fellow was struggling against the powerful, discolored current. In time a red tail waggled for a second within reach, and I drove the grains into the water a couple of feet ahead of where the tail had disappeared. A grinding jar told that the points had struck a fish well forward, and as the shaft whirled round with the flood, I pulled it back and landed a heavy mullet.

The writhing eddy just below the confluence of the two currents seemed to entice many wearied fish, and every few moments I'd catch a glimpse of a fin or tail. But the stream was far too muddy for sure work, and many a "water jab" resulted. Once in about five thrusts the points would touch a fish, and at longer intervals victims were secured. It was quick and interesting work, and supper-time rolled round before I had given a thought to the venomous Old Party with the scythe. I had killed four good fish and a couple of worthless suckers when I realized that farmers' wives invariably make fussy preparations for "town fellers," and that decency demanded that I should make an effort to be on time. 
So I cut a switch, strung my mullet, and picked up the spear preparatory to starting. A glance into the water of the creek caused me to drop the fish and stare in astonishment. About a foot below the surface, and not more than a dozen feet away, a long, gleaming shape was plainly visible. Wickedlooking yellow eyes glared from one end of it, and a broad tail sculled softly at the other. At first I thought it was surely a muskallonge, but the season was too early. A second scrutiny proved it to be a pike - and such a pike! It had seen me before I noticed it, and it was ready for one of its electric rushes at an instant's warning. I cautiously edged round into a good position, thinking meantime of the lusty "jacks" of ancient moat and fen, for this was the largest pike I had seen.

"Blame you, you most scared me! You must weigh over twenty pounds," was my thought as I got the spear into position. Then I hesitated. Should I essay a sneaking side thrust or stand up like a man and hurl the grains? The first was tempting - but 'twas a noble fish worthy of knightly feat, and, besides, I was not at all sure that it would tolerate a nearer approach. The doubt decided me, and, little by little, I raised the spear and got into position. Once I sighted, twice I sighted; then involuntarily exclaimed, "Now!" and drove the steel truly at a point below the glaring eyes. As the shaft left my hand a laughing voice echoed, "Now!" then changed to a yell of astonishment, which wound up with, - "Great Cæsar's ghost! Wha-a-t a fish!"

I knew the voice and guessed that Jack had am- 
bushed me, expecting to find me at the creek when I failed to appear at supper-time. All that I saw for the moment was a great, foamy swirl of water, a struggling, burnished body, seemingly as large as my leg, a glint of the grains near a broad, flapping tail; then the staff floated idly toward me.

"He's loose! He's upstream! Run him, man!" shouted Jack, as I grasped the grains and sped away. A wake in the water now and then hinted where the fish was, and I belted along as fast as the waders and treacherous footing would allow. At the end of a hundred-yard burst I had enough, and at the same time saw that further chase was useless, for the creek suddenly broadened into a deep pond. As I pulled up I caught a glimpse of the fish near the bank, and within reasonable throwing distance. It was moving slowly, and a white scar near the tail showed where a tine of the grains had failed to hold. With a last desperate effort I hurled the shaft again. It left my hand all right, but an unnoticed twig caused it to swerve, and the steel struck the water a yard from its mark. The startled fish disappeared in the pond like an arrow of light, while I thought hard things of luck in general and this kind of luck in particular.

Naturally the adventure made us keen, and as soon as I could escape from the overplus of pies, etc., we went back to the creek. A big fire of driftwood was soon started, its red glare showing far upon the river. With grains in hand, we watched many a passing fish, and once in a while we struck mullet and suckers. Time slipped away; duck clove the darkness overhead with hissing wings; owls 
"How-do-ed?" to one another across the river, and finally a wailing "bla-a-a-at" from a big tin horn warned us that Jack's father considered it time to lock up his house for the night.

If there is one thing I dislike more than getting into bed, it surely is getting out again, and Jack had to haul me bodily to the floor in a queer half-light, which he termed morning. He had chores to do before we were free to go, so, after plunging my head into cold water, I bore a hand and helped him out. The rapidity of the feeding process must have delighted and amazed the stock - but we wanted to go spearing! Jack moused round and fixed up two goodly bowls of bread and milk, and as the sun climbed above the woods we were ready to depart. At this juncture Jack thought of an evil thing, and exclaimed: "Say, how'd some hard cider catch you 'fore startin'? Ole man's got a barrel of it, and it's bully!"

I rather fancied the scheme, and we sneaked into the cellar and put at least a quart apiece on top of our bread and milk. It was mild, palatable stuff, and it slid so meekly out of the old tin dipper that I trusted it implicitly. Jack spied an empty quart bottle, and, with many low chucklings, we cribbed the full of it and made off. We went first to the mouth of the creek, and found the water in prime condition. Jack, however, was eager to get upstream, to look for our lost big fish, and he urged me to lose no time, as other spearsmen might be up from town and at the headwaters before us. When we reached the place where the fish had disappeared I halted, while Jack hurried ahead to where the 
creek flowed in. Considering that the fish was slightly wounded, it might still be in the pond, so the best plan was for me to wade in, and try and drive it upstream to the ambushed spear.

I beat the pond thoroughly, striking the water with the spear-shaft as I went, but no big fish passed Jack. Three small pike gave him a chance, which yielded one victim; but when I reached him, he agreed that the big one must have gone farther up the creek.

Then followed a long, patient hunt. We moved abreast, one on either side of the water, searching every possible cover, and jabbing our grains into every pool too deep and dark for eye to penetrate, but for a long time found no trace of the big fish with the white scar near his tail. Other fish of fair size we occasionally routed out, and several were secured and placed on our respective switches.

One capture will show what quick work may be done with the grains. At a point where the creek was less than four yards broad and perhaps two feet deep, we noticed a decided wake on the surface. Jack ran ahead and shouted: "Look out! I've turned three good ones." Then he made a few steps forward and speared a fine fish. A mimic wave rushed down on me, and I caught a glimpse of the two pike, one a yard or more in the lead. This was the smaller fish, but I had to strike it, or suffer it to reach a difficult piece of water. As it dashed abreast of me I struck it near the head, and at once heaved on the shaft à la pitchfork, following with a sharp, twisting, backward jerk as the steel was above my head.

The fish tore free of the tines, and went sailing 


\section{Sporting Sketches}

yards away into the field. The larger fish had paused for a second or two as its leader was struck, and gave me time to whirl the grains into position for a throw. The fish had passed, but a swift shot after it landed the tines in its back, and we got all three.

This was such a lucky performance that Jack produced his bottle of hard cider, and we made "two bites" of it, to save lugging the flask farther. The sun had by this time gained full power, the surface of the water seemed to be brighter and more dazzling than usual, and some way or other we seemed to laugh more over the capture of our three prizes than was really necessary. I know, of course, that I was laughing mainly at Jack, and my mirth did not decrease when he began to talk about the big fish and what he'd do if some son-of-a-gun from town happened to get it before we could find it.

In time we reached a small log bridge spanning the stream, and here we paused to bask in the pleasant sunshine and to get pipes going once more. Somehow I felt strangely lazy and drowsy, and Jack, while he did an enormous amount of talking, failed to interest me overmuch, or to mouth his words in his usual crisp style. We sat till I caught myself actually nodding; then we laughed some more and got upon our feet. Before leaving the bridge I proceeded to examine the water below it, and made an important discovery. Under a large log lay a long greenish form with fins that wavered slowly, and a tail that sculled with just sufficient power to keep its owner in his hiding-place despite the current. Near the big tail a white scar showed distinctly, and I knew that at last we had found our lost friend of 
the evening before, though fully two miles from where I had missed him. He must have picked up a comrade while travelling, for on looking again I plainly saw two huge pike and, mirabile dictu, each had a scar near its tail! I gravely asked Jack to gaze upon this mystery of the waters. He took one look, then exclaimed: "Sufferin' cats! Ram it hic! - to - the - hull - three of - 'em!"

I sighted carefully at the biggest, yet hoped to spear both, and drove the grains with unnecessary power. My arm felt an unexpected jar, but I whooped out: "Hurra! I've got one anyhow!"

"Got nuthin'! There they all go - You speared the log, you - hic - fool you - yer full!" politely commented Jack. After I had fiddled for some minutes trying to get the grains free of the $\log$, and had calmly stepped into water that came inches above the tops of my rubbers, I realized that Jack had evidently cultivated the power of observation. Hard cider was peculiar stuff surely, so I wet my head and splashed water into my face, then stumbled ashore. The ducking improved matters a bit, but I screamed with laughter when Jack blurted out: "Well, hic - you're - nice - feller - to - go spearin'! Let's take after'm - they all run upstream."

"There was only one fish, Jack," I ventured.

"Oh, shut up!" he said. "Bad enough to miss the hull three without trying to lie out of it. I hic - hate a feller'll squeal when he makes - a fool - of - hisself! "

We soon found the fish again. It must have been severely hurt, for by some half-submerged 
scrub I saw the familiar shape and the white scar. This time - thanks to the cold-water treatment the fish was alone. I warned Jack, and then stole upon the quarry. A few yards above where it lay was a very shallow little rapid, the water sliding, six inches deep, over a sort of slope of hard blue clay. There Jack stationed himself in a rickety sort of way to head off the fish in case I missed it. As he left me he said, "Ef you mish um again - an' I bet you do - you watch me nail um ef he tries to monkey with me!"

To be candid, I did miss him. How or why the cider can explain. I had a fair, open chance; the fish never stirred till after the grains plunged into the water at least six inches to one side, but it was a palpable "lost bird." The big pike was slow in its movements, and Jack had plenty of warning before the shovel-nose showed in the rapid right at his feet. He jabbed once, twice, thrice, with short, swift movements, like a yellow hen pecking corn, but he missed. I could have run to the scene in time to have tried a shot myself, but the picture was altogether too funny for me to tamper with. As he missed the third try, he ran forward into the water, stumbled, and landed on his feet and hands. He got pretty wet, but was up in an instant and, as the fish showed at the very head of the little rapid, he swung his spear aloft, and brought it down with a smashing two-handed blow, as an old dame handles an axe. The shaft snapped, but the grains happened to land flat on the pike and left it dead. The next swirl of water brought the long, mottled body to Jack's hand and he stumbled to terra firma with 
his prize. As we felt averse to exertion, we lay down to smoke.

Trouble of an unexpected nature was brewing. We had barely got our pipes going when we heard voices and soon saw three hard-looking citizens approaching. They had grains, but only one small fish, and were using pretty rough language. They knew me well enough, and one of them presently hailed me and asked, "What luck?" Jack grunted out, "Don't bother with that truck - they're no good." It seemed that the men had raided his father's orchard and melon patch so many times that they had got themselves disliked. However, I held up first, my lot, then Jack's, then the great fish which had not been put on the switch. The two strings caused some profane.comment; but the size of the big fish raised a whoop of surprise, and through the creek they came for a closer inspection. When they reached us, I saw they'd been drinking more or less, so just to turn matters into a safe channel, I gave the two fishless fellows a fair-sized pike each. This was a veritable boomerang. Instantly two flasks were produced, and each man swore that I was a good fellow and must drink.

Now, I had not yet entirely shaken off the hard cider, and I knew better than to put straight rye on top of it; but it was very difficult to beg off. I jollied the trio as best I could, and might have smoothed things famously if Jack had kept his mouth shut. But suddenly, to my horror, he sprang to his feet, shook his fist at one man and roared: "You're a blank thief! I know you. Now you get right out of here!" 
This meant "scrap" for sure, and I didn't like the prospect a bit. Three to two, and every man armed with grains, was nasty. The three could certainly do us if they wanted to, as there was little to choose between any two of the party, so far as I knew. The man spoken to merely stepped off a few paces to one side, drove his spear into the ground, shed his coat, and came back saying, "Jest as soon tackle you as eat." If it hadn't been for Jack's hard cider, I would not have worried much about him, for he was a powerful, though clumsy, fellow, trained by plenty of hard work. The chance of the others mixing in was promptly settled by one of them saying to me, "You keep back on your side, and we'll do the same." I presume that I should have done my best to check hostilities, but, honestly, I didn't feel called upon to start a Sunday-school just then. So long as they scrapped fair and wanted to, and I didn't have to get punched or speared, I was quite willing to look on.

There was no pretence at science. They slugged each other, bang-bang, half a dozen times, missed with many wild swings, and then Jack went down in a very wet spot. As he picked himself up I advised him, "Best clinch him, Johnnie," and was promptly told to "shut my trap" by the other spectators. Jack heard, however, and soon they were all snarled together, kicking up ground and milling away at a great rate. In the roll around they got mixed up with the fish and we shifted the grains well out of reach, for both were now pretty well scraped and punched and screaming mad.

It was an even thing until they broke apart on 
the ground. Just then Jack ran his nose against a hot one aimed at random, and as he sat back his hand chanced to light on the big pike's head. With a yowl like a mad cat he leaped up and whirled the long body of the fish hissing through the air. The tail landed with a swat, like two boards struck together, fair on his foe's mouth, only to rise and whistle again and reach the jaw with a fearful crack. This blow broke the fish into fragments, and Jack, with a quarter section of head and battered flesh clutched tight in his right "maulie," piled into his fallen enemy and belabored himself lustily. From below the Gatling of fishmeat presently came the required squeal, and the fight was done.

Jack left fish and grains and marched straight across country, madder than a wet hen. As the defeated one washed at the creek the three sinful spectators rolled on the ground and howled with boundless joy, and I had finally to grab the fish and grains and flee as best I could for laughter from insistent proffers of flasks. When three fields from the battleground I could hear the two yelling with delight, and I'll lay that the fighter appreciated the force of "save me from my friends" before they got through with him. 


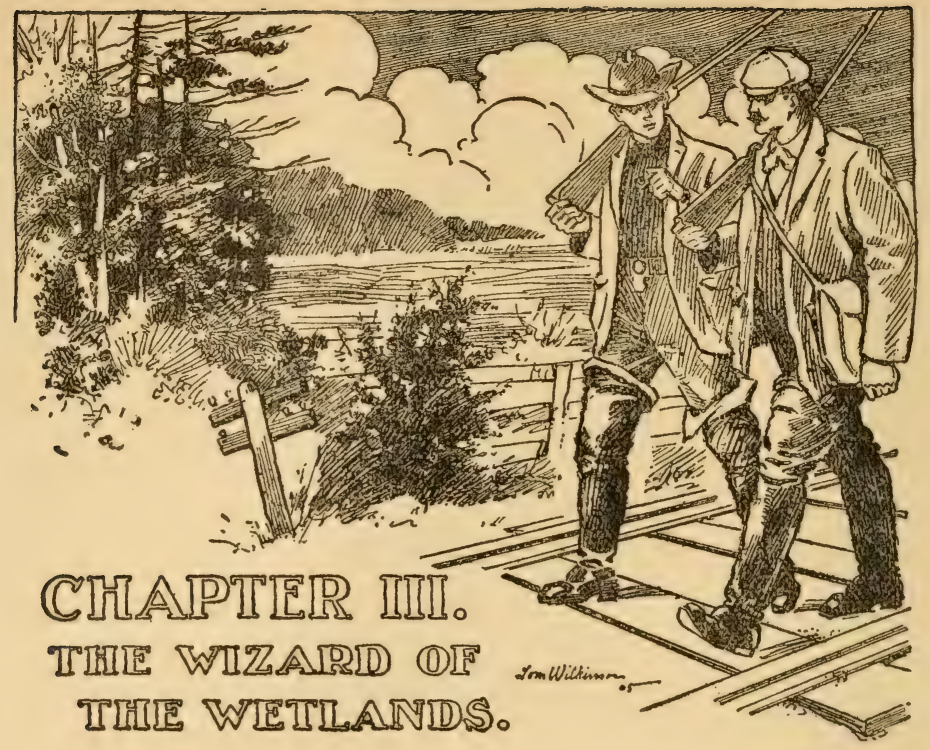

WHy a wizard? Yankee-fashion I might retort with, Why not? When a bit of brown bird life only about eleven inches long can cause a six-foot man to do all sorts of crazy stunts, I should say the wee fellow at least possessed peculiar powers. That the snipe can make a lazy, heavy sleeper rise at gray dawn and go toiling across weary leagues of bog, morass, and muddy mess for perhaps eight or ten hours at a stretch is a well-known fact. That he can make a temperate man drink, a truthful man lie, an accurate man miss, and a good man curse, he has repeatedly proved, while at the same time with a mere wave of a wing he can cause a sinking heart to leap with joyous pride and a weary eye to flash with sudden fire. These things, and a few others which need not be dwelt upon, backed by a flight of the now-you-see-it-now-you-don't - the-quickness- 
of-the-wing-deceives-the-eye order, appear to warrant the title herewith bestowed.

And with all his eccentricities he is a good little wizard and one of the best loved of all our lesser game. Once a snipe shooter always a snipe shooter might be truly said, for it is questionable if even the Bob White has more valiant champions than stand ready to defend the honor of the long-billed, bentwinged master of the mud.

The snipe, properly Wilson's snipe, Gallinago delicata, but commonly known as English snipe and wrongfully called half-a-dozen other names, is a widely distributed species. It visits every state at some season; its northward migration extends within the Arctic Circle, while it is known to go southward to northern South America and the West Indies. Comparatively few of the birds which move northward from February until May breed south of the international line. It is quite true there are breeding grounds at various points of the Northern states, but the great breeding range extends from latitude $42^{\circ}$ north to some undetermined point much nearer the Pole than most sportsmen will venture.

Some time in September the first south-bound bircls pass below the Canadian grounds, and soon most of the suitable marshy bits of East and West have their share of long-billed prizes. Then begins an astonishing attack, which extends from ocean to ocean and gradually sweeps southward from Canada to California. Probably tons of lead, half of which is wasted, are fired at the artful dodger.

The sexes are alike, the description being as fol- 
lows: Top of head, black, with three buff stripes; neck, buff, lined and spotted with black; back, black, feathers barred and margined with rufous and buff, the latter giving a striped effect; rump and upper tail coverts, rufous, barred with black; wings, sooty black, feathers barred with rufous and margined with white; primaries, blackish, web of first white nearly its length, edged with white at tip; tail, usually of sixteen feathers, the three outer whitish with narrow black bars, the others black with rufous bar and tipped with pale buff ; chin and upper part of throat, pale buff, lower throat and breast, buff, spotted with sooty brown; flanks, white, barred with black; abdomen, white; under tail coverts, buff, barred with sooty black; bill, legs, and feet, greenish. Length, IO $\frac{1}{2}$ to II $\frac{1}{2}$ inches; wing, about 5 inches; tail, $2 \frac{1}{4}$ inches; bill, $2 \frac{1}{2}$ to 3 inches.

Many sportsmen of the gray-headed brigade still insist that, like the woodcock, the snipe lives by what they term "suction." Better-informed people, of course, know that both birds eat worms, and an astonishing number of them, and that the worms are secured mainly by probing (boring) for them with the peculiarly sensitive bill, the upper mandible having a very flexible tip by which the worm is felt, seized, and drawn from the earth. By this, however, is not meant that snipe and cock invariably bore for their food. Both will take worms crawling upon the surface, and both frequently feed in thickets and on almost dry ground, where they secure the prey by turning over fallen leaves.

When migrating the snipe travels by night, and while some excellent authorities have claimed that 
a moonlit journey is necessary, or at least preferred, my experience has taught otherwise. More times than can now be recalled I have catnapped through the black monotony of a steamy spring night so as to be on precisely the proper spot when the first flight of geese came in to feed at gray dawn. And at intervals throughout such nights I have heard the wings and voices of myriad snipe hissing and rasping across the black mystery as the first comers of the year sped to the fat muck of thousands of acres of wetlands. Moreover, I have toiled till dusk over fenceless fields of black tenacity and seen never a bird, nor a boring, nor a chalking, nor anything that is his; have turned in dead beat at some farmhouse, been literally hauled out, against the grain but in accordance with positive instructions, before dawn, and have later found the birdless ground of the previous evening to be swarming with silent, skulking snipe, which if not weary from a long flight certainly acted like resting new arrivals.

I have heard snipe moving by moonlight, and that many times; but the night of nights to bring the northward-bound birds is dark and damp with a puff of warm breeze from the south and a dash of warm rain. Upon such a night I have known the snipe pour in so that wings or voices were audible nearly every moment. Pretty good snipe grounds? Indeed they were. When "Frank Forester" first tramped them, he could, with a muzzleloader, bag twenty, thirty, and forty brace in a day; and not many seasons ago the keen men who worked those grounds took each one hundred shells for one day's sport. And this did not mean that each bird required a 
deal of shooting. On the contrary there were men who might average fully three-fourths of all their birds and who were able to grass snipe after snipe without a mistake upon days when things worked just right. I have seen a private match at twenty birds per man result in a straight score for the winner, while the loser missed but twice.

While the great flight of snipe extends well to the northward of New England, occasional nests have been found in Connecticut and Pennsylvania. A slight hollow in the ground, or a tuft of rank grass, holds the three or four eggs, which are olive-gray washed with dull brown and spotted and scribbled at the larger end with deep brown and black. The courtship is peculiar, the male and female frequently rising high in air and sweeping about in swift circles, then diving earthward at full speed, at the same time producing a queer rolling sound impossible to represent on paper. This "drumming," as it is termed by sportsmen, is also frequently performed by single birds and late in the season as well as during the period of courtship. A drumming snipe not seldom ascends until almost invisible, then seemingly flies straight down at an amazing rate, whereupon is heard a loud humming, presumably caused by the rushing of the air through the primaries. An empty, corkless ink-bottle swiftly thrown will produce a similar sound, and the old schoolboy trick of making a nail hum is no bad imitation.

The snipe occasionally takes to some large, horizontal limb, more often alights upon the top rail of a fence, a stump, or big log, and I once saw one standing on the top of a stout post which supported 


\section{The Wizard of the Wetlands}

wire. Another bird was seen to pitch on a small stack which was surrounded by water, and yet another upon the roof of an old outhouse. There was no mistake in either case, for I flushed and killed the bird on the stack and had a close view of the other before it left the roof.

The names by which the snipe is known in various localities are rather numerous and some of them quite curious. While the correct one is Wilson's snipe, we find "American snipe," "common snipe," "snipe," "meadow snipe," "little wood-snipe," "English snipe," "bog snipe," " marsh snipe," "Jack snipe," "alewife bird," "shad spirit," "shad-bird," and "gutter snipe." It is " a snipe or snite, a bird lesse than a woodcocke," in Baret's "Alveary," I 580 ; and in Drayton's "Owl," I 604, occurs, "the witless woodcock and his neighbor snite." Other sometime crumbled old parties speak of "simpes" and "simps," and I sincerely trust their shooting was a lot above the average of their spelling. The name "Jack snipe," so persistently used by some writers who ought to know better, is misleading, as it rightly belongs to a smaller bird which so far as may be learned from authentic records has been taken only upon the other side of the Herring Pond. One excellent authority refers to it as "a twiddling jack" and unworthy of the rotice of sportsmen.

The flight of the snipe is swift, vigorous, and usually for the first few yards erratic. The bird gets under way smartly and as a usual thing goes boring up-wind in a style rather suggestive of a feathered corkscrew. A series of electrical zigzags gets him to top speed, whereupon his progress stead- 
ies a bit and he darts away in something more like a straight line. As a general rule, a flushed bird springs a few feet into the air, hangs for the fraction of a second, then begins to twist and dodge as though the Old Boy was at his tail. It would be very interesting could we discover the original cause of the dodging. Possibly some ancient foe, now long extinct, was best baffled by that mode of flight, for there usually is some such explanation for peculiar actions by wild things. Because the flight happens to be puzzling to a gunner is no guarantee that the bird dodges for that purpose - such an explanation would imply a deal more intelligence than the entire tribe of snipe is possessed of. Snipe, of course, dodged on the wing long prior to the appearance of firearms, and it is extremely unlikely that the erratic flight has anything in the nature of protective tactics against the devices of human foes.

The fame of the bird as an object of the sportsman's pursuit has been fairly earned. Swift, small, erratic, he presents the most difficult mark of all our game of shore and upland. In my opinion only teal and canvasback are harder propositions, and with them the real difficulty is apt to be more of weather conditions and the methods usually employed rather than the speed of the fowl, great though it be. The shooting of the snipe is unlike that of any other bird. Some men attain truly wonderful skill at it, and as a rule such men are referred to as "crack snipe shots," instead of the broader term "crack shots."

To me there is a trifle too much of sameness about it. I am no shirker in the field, yet there is 
a tinge of monotony about marsh lands and unending mud and water which cannot hold me as does the infinite variety of conditions, the marvellous beauty of turning foliage, and the clean, vigorous action of sport on the uplands. In point of fact I could enjoy six days per week of grouse, quail, and cock; but it is questionable if the charm of snipe shooting would wear equally as well.

And now the actual shooting. The best gun is a light, close, hard shooter, because the mark is swift and small and half the chances at longish range, the average rise being yards farther than is the rule in Bob White shooting. I use number eight shot, because to my notion the popular number ten is apt to mean too many pellets in the meat and consequently too much lead for busy teeth later on. The quantity of smokeless powder will depend upon the gun - I believe in using plenty, all the gun can burn properly, for the large percentage of long shots demand all possible power. When birds are few, a free-ranging pointer or setter is an invaluable helper; where birds are very plentiful, a reliable spaniel, that will keep at heel until ordered out, is all the dog required. I am not overfond of running a fine pointer or setter all day on wet mud. It is hard upon his feet and coat, and unless he be carefully washed and thoroughly dried so soon as the shooting has ended, he is apt to have a miserable time of it during the long ride home and be all stiffened up in the morning. Very frequently, too, a fine dog, unless broken on snipe, is apt to try to get too close to his birds and so cause flushes. When snipe are wild, as often happens, a dog must point at long 
range. Dogs broken on Bob Whites, and in every way reliable on the uplands, could not be expected to understand this, and some of them require days to master the peculiarities of the long-bills.

A great many men employ Bob White tactics when after snipe, especially in regard to beating upwind. This I do not advise, because it means a lot of birds boring into the wind's eye and dodging like mad while offering the smallest possible marks. A cross section of a snipe going straight away is much smaller than many people imagine. The vitals of a bird so going might be covered by a silver dollar, the head is apt to be covered by the body, while only the edges of the wings are exposed, which means an extremely narrow surface. Because the bird loves to bore up-wind, I walk down-wind, thus securing a quick chance as he curves into the wind in front, or else a square crossing shot as he passes up-wind at either side. In these positions the effect of his dodging is minimized, while I still retain the privilege of making a half turn and using the second barrel at a straightaway or almost a straightaway bird that has got through dodging and is trusting solely to speed. In all these shots the gun has a better chance, in a straightaway after the turn, while, of course, the side shots mean all one side of the bird and most of the long wings fully exposed. This gives the gun a rather large target instead of a very small one, and practically does away with the saving erratic flight.

The reason why some men work up-wind is because they imagine the straightaway shot to be easier. They fail at crossing shots, not because the 
shot is difficult, but because they have not learned how to make it - in other words they never have mastered the highly important points, allowing a fast bird plenty of lead and pulling trigger without checking the steady swing of the gun. Unless one is holding a tremendous distance ahead, to stop the swing of the gun means to miss through shooting behind. Quickly as shot travels there is a fractional loss of time between the beginning of the movement by the trigger finger and the arrival of the pellets at any point; - for convenience say thirty or forty yards from the muzzle. During that interval, brief though it be, a snipe will travel a certain distance, and that distance is precisely what the gun should be ahead of him when the trigger finger starts to pull.

Those who have not actually experimented with the pattern of guns and the matter of leading fast birds according to distance, might with advantage make a few patterns at twenty, thirty, and forty yards, using a thirty-inch circle upon large sheets of paper. The results will show a spread of pattern as the distance is increased, and let us hope an even and fairly close distribution of the pellets, for that means a useful field-gun. The twenty-yard pattern will show the shot so closely bunched that no snipe within its circle could escape instant death. At the distance, then, the one necessary thing is to get any part of that pattern on him; but correct shooting would demand his being exactly centred. To insure this the gun would have to be held just ahead of him and kept swinging at exactly his speed and not stopped as the trigger was pulled. At thirty yards 
it is still more important that he be centred, because the charge has loosened considerably, while the most pellets, hence the smallest gaps in the pattern, are in the centre. For the same reason that necessitated holding just ahead at twenty yards, the lead must now be increased one-half to insure the best results at the ten yards of increased range. At forty yards the pattern has opened sufficiently to allow free passage to an object the size of a snipe at several points toward the outer limit, yet there remain enough closely placed pellets at the centre to do the work. If a second smaller circle be now described, which includes all of the paper which shows no dangerous gap, the deadly portion of the charge will be determined. To make sure of a snipe, that portion must cover him at forty yards, and to insure its reaching the proper spot at the exact moment, the gun must be held ahead just twice the distance which the twenty-yard range demanded. In other words, as the shot leaves the muzzle, the latter should be some inches ahead of the bird and swinging in true time with the mark. At greater distances the lead must be increased in proportion; but other possibilities now creep in, because, as the charge spreads more and more, too large gaps may appear almost anywhere, which means the extreme reliable range of the gun has been passed.

A few, possibly successive, extremely long shots prove nothing beyond the fact of the gun's being a hard shooter, as at the same time the patterns might be poor. I have killed snipe when they seemed beyond the range of the gun; but such kills are merely accidental. No wise man would dare wager upon 
such shots because he knows the pellets might not again find the mark once in ten attempts, although given the proper allowance for the distance.

There are two deadly methods of shooting straightaway snipe. One is lightning-fast, the next thing to out-and-out snap shooting. The other is to wait until the bird has completed his shifty first flight and give it to him the moment he steadies. Both are scientific. I prefer the former, because, being naturally very quick with my hands, I can get on a bird before he has time to begin dodging. Were it not for this, I certainly should wait. A man to shoot at all evenly must do one or other, for any attempt at a compromise will leave him neither quick nor slow and prone to fire at precisely the wrong moment, when the wizard of the wet lands is in the midst of his little trick wherein the quickness of the wing deceives the eye.

And now a glimpse of snipe shooting in which the characteristic sameness of leagues of wide wet lands and successive springing, dodging, scaiping sprites was a bit varied. Unto me spake long Tom, and his words were crisp and as follows:-

"Now will you be ready at 3 A.M. and game to foot it out?"

"I will!" said I.

I meant it, and I had need to, for when long Tom got through with you, other things also seemed long, notably that awful final homeward mile. Our campaign necessitated a gray-dawn start, because it began with a six-mile tramp in cold blood along a railroad track. We might have driven to one corner of the ground, but to take a horse also meant 
that which we both detested - a fixed point to which we would have to return at evening. And when you take a horse snipe shooting the birds invariably are most abundant farthest from where you tie the brute, and at nightfall you are apt to find yourself only five miles from home, but eight miles from the horse. Then, of course, you have to but, reader, you understand!

We started at dawn, and so soon as we had reached the railroad Tom tersely remarked:-

"Come, shake those long legs. I've got you where I want you now!"

This was pregnant with fell intent, and I grinned defiance, for we were about the same age and weight, in fact, six-foot two-hundred-pounders, and about even all around. As is usual when a couple of behemoths get to playing, there was considerable pounding of gravel.

Before us spread miles of ground, of all degrees of consistency between semi-liquid and putty-like stiffness. A strip of it, perhaps two miles long by one-half broad, began near our feet and ended near a dim blue mass which betokened higher ground and forest, and near those trees was a broad creek.

"Come on! I've got you now!" chortled Tom, and I thought of Kilkenny cats and sighed for the things which I knew would happen and unwittingly for one thing of which neither of us dreamed. For half a mile the footing was fairly good, and, as we both wore ordinary walking boots and leggins, we escaped the harassing drag of the customary waders, which are good enough when one intends to drive home, but worse than useless for a long tramp 
on dry going. Presently we began to get a bit anxious and to more than half wish for the canines left securely kennelled at home. Upon such ground, with birds plentiful, dogs are unnecessary, but where, as sometimes happens, the snipe are broadly scattered, the conditions are reversed.

We were some thirty yards apart, when suddenly I heard the well-known whip-hip-hip of bent wings and the "Scaip-sca-ip!" as an artful dodger flushed before Tom. Old "Take-your-Time" was a picture as he flashed the beautiful arm into position, then waited those straining seconds till the dodging ceased. Then came the puny "squinge" of smokeless, and somebody's long bill was settled in full. Breaking the gun as he went, and never taking his eyes off that one spot of a thousand similar spots, Tom moved forward thirty yards and retrieved. The whole performance was a perfect illustration of the deliberate method of which he undeniably was a master.

"That long brute's dead-on to-day," was my inward comment, as I moved ahead.

"Whip-hip! Whip-hip - Scaip-sca-ip!"

A brace of unpatented corkscrews were ready to bore holes in the whence, but the light gun just cleared its throat a couple of times and both birds hearkened to the warning, and that before the second had time to make one decent twist.

"I'll mark the last one," said Tom, as I went to the first bird. Right well he knew how I'd completely lose track of one the moment I left the firing point, and he followed the best method, to stand in his tracks and keep his eyes on the spot and direct 
the search for the second. When shooting alone, or far from a comrade, and a double is made, I reload before stirring a foot. This leaves two empty shells on the ground, to indicate my exact position, and this, with the memory of the turn or partial turn made for the second, gives a close line on its whereabouts. Very frequently this saves a bird and valuable time, for, at the worst, it will guide to within a few yards of the game, and every yard saved in beating foot by foot through grass is important. Hat or handkerchief dropped at the firing point also makes a useful mark when grass is tall. A snipe breast upward is easily seen, but only about half of them fall in that position. Back upward, the striped effect blends curiously with grass and its shadows, and a winged, or otherwise, wounded, bird seems to know this, and to act accordingly. Men trained on the wet lands acquire a marvellous knack of marking down, and a mighty useful accomplishment it is.

Moving on, Tom flushed a brace on bare ground and scored, the last bird falling full fifty yards from the gun. I marvelled, for it was a long, clean kill. Before he reached these, two single chances were offered and accepted, and a third bird went careering away, rising higher and higher, like a winddriven leaf. As Tom's birds lay upon easy ground, I kept my position, more from habit than with any idea of being of service. A wave of his hand directed my attention to the late towering bird, which, as they frequently will, had decided to return. Like a plummet it fell some thirty yards away, and, as an experiment, I held about four feet under, and it hit 


\section{The Wizard of the Wetlands}

the mud with a resounding spat. It was a great shot, and Tom's emphatic "Broke its own neck" was merely his way of expressing keen appreciation.

For an hour after this there was very pretty shooting. The birds were nicely distributed, rising singly and well within range, and only a trio proving the truth of the oft-repeated "Scaip - scaip!" Finally a missed bird pitched in a broad patch of short stuff, which showed a springlike greenness, and Tom turned after it.

"Look out there! Where the mischief ye goin'?" I yelled; but it was too late. In an instant, it seemed, he was down and floundering, and the whoop he uttered might have been heard for miles. If any of my readers have attempted to run in snipe ground, they will understand my task. Luckily it was short. To skin out of the coat, drop gun and hat upon it, and start for him, was the work of very few seconds. His face was ghastly white, and the treacherous ooze was up to his belt, and he was slowly sinking. After his first wild scramble, he had wisely ceased all effort, but he was scared clear through. So was I, for that matter, for it was a nasty situation. He had his gun, but I dared not venture near enough for that to be of use; besides, I questioned if either of our grips would stand the pull upon such poor holding.

The belt and corduroys! Glory be! 'Twas a noble inspiration - Nay! The very thing I was panting for - such things are made long for sixfooters. Those who have attempted to take off trousers while standing on snipe ground will under- 
stand why I presently cursed and sat down upon cool, moist mud; but the legs were full measure and the material stout. The seam never would stand the strain; but the good old belt, made fast to the upper part of one leg, carried across the seat and again made fast, would take the direct pull. In a few moments the tackle was ready, and I reached for his gun. He hated to let go of it, and I didn't blame him.

"Here's your life-line, remember they cost a tenspot," I ventured, as I tossed him one leg of the trousers. The way his hand clutched the cloth was a marvel to see, and I at once realized that he had to be got out, or I'd have to paddle home without any panties. "Steady now; wiggle your legs a bit," I grunted as I cautiously put on the strain. There was one moment of agonizing doubt; then Thomas began to come, and finally, with a sort of regretful sucking sigh, the awful trap let go and he came slithering out of that.

Mud! I mined into a pocket till I found paydirt - otherwise his flask, cleaned it with grass and we halved the contents. Then we looked at each other and laughed in a semi-hysterical sort of way, for each knew, and well, too, how serious a thing had passed. 


\section{CI几APTIER IV. BIEACIR COMIBIERS.}

Somewhere across the vast dome of blue which arches in flawless beauty above the Great Lakes on fair May days are unblazed, mystic, invisible trails. Unseen by human eye, unknown to human brain, understood only by a marvellous God-planted instinct, these trails extend now, as they have extended for uncounted ages. The microscopic eye of science scans the distant blue in vain for trace of them, or for the unknown signs by which these trails are followed with unerring certainty by uncounted hosts of airy voyageurs. The scientist knows of the existence of the trails and of their myriad travellers; he knows that somewhere in the glowing south and somewhere in the lonely north the unblazed trails begin and end, and that they are marked here and there, at proper intervals, by resting-places, for the trailers.

Some day, beyond the misty clouds of counted years, ere brain's first feeble thought was rudely scratched or chipped upon time-defying stone, the God who made the birds held two of each race in mighty hands and lovingly whispered to them the secrets of sky-paths and of their wondrous journeyings to be. And with that knowledge, and with the power to transmit it to their kinds, flew forth the earliest pairs to test together the trails from south to north 
and from north to south, and in the first testing to prove their teacher true and kind.

For ages the rivers of nervous life have flowed to and fro atween shadowy banks with unfailing regularity as the ordained seasons change. In the soft spring nights the hurrying pilgrims pass unseen, but earthward from the trails sink sounds of life at speed. The hum and hiss and flick of busy wings, the queries of many tongues questioning and answering anent the way, fall in musical whispers upon the trained ear of science hid in the blackness far below, and tell who press the trails so fast, from whence and whither bound.

There are other trails than those above the region of the Great Lakes. East and west, above Atlantic and Pacific shores, above the great plains and forests, are trails traversed by their own multitudes - convenient routes for feathered offspring of certain sections of country. The peoples that swarmed these many trails in the past and unfortunately only traverse them in decreased numbers now, represent mainly the two great orders of birddom, - the Grallatores and Natatores; in plain North American, the tribes of waders and of swimmers. Nearly all the species embraced within the two orders are considered worthy victims for the true nimrod's weapon, and it is to be regretted that to the sport-affording and edible qualities of many of them must be attributed their present scarcity in districts where not many years ago they absolutely swarmed during their periods of migration. The order of Grallatores comprises such families as the herons, cranes, bitterns, snipes, plovers, phalaropes, 


\section{Beach Combers}

sandpipers, and rails, while among the Natatores are the swans, geese, ducks, loons, cormorants, sheldrakes, gulls, terns, gannets, guillemots, grebes, petrels, auks, and puffins.

Greater or lesser numbers of nearly all of these families annually flew (and many of them still fly) the airy trails above the Great Lakes and halted at the several resting-places which the nature of the country afforded. Prominent among these restingplaces for the ofttime weary and storm-driven pilgrims were the sandy reaches now known as Toronto Island, opposite the city of Toronto, situated upon Toronto Bay, an indentation of the shore of Lake Ontario. This formed a perfect paradise for shore and aquatic birds, and to-day the bars, in spite of being overlooked by a city of about two hundred thousand population, are frequented by a variety of the families of both the orders.

It seems that in the past the island, beaches, and bars of this bay formed one of the most important "road-houses" for feathered travellers along the northward route, and many a rare and valuable specimen unknown to the average sportsman has been there secured. Birds rarely found in Canadian collections, such as the ruff, red phalarope, avocet, and stilt, now and then fell to the guns of men who sought the island before break of day, and who lay patiently in wait till evening shadows closed. A few decades ago one gun might bag anywhere from one hundred to upward of half a thousand plover of various kinds in a single day's shooting, and even now men who understand the annual flights of migrants can bag respectable lots of "black-hearts" 
(red-backed sandpipers) and other waders in the spring.

Among the rarer birds known to have been killed on the island and adjacent marshes are the white pelican, trumpeter swan, white-fronted goose, snowgoose, king eider, that rava avis the harlequin duck, canvasback, and sandhill crane.

Another famous resort of these migrants was the marshy country about Lake St. Clair, the link between Lakes Huron and Erie, and on these grounds, a few years ago, when I was completing one of the finest collections of birds in Canada, I saw, handled, mounted, or shot specimens of the white pelican, white heron, sandhill crane, avocet, red and gray phalarope, cormorant, brant, trumpeter swan, and snow-goose, and other rara aves, among a miscellaneous assortment of swimmers and waders.

Some of these birds have been questioned by well-informed ornithologists, but the best possible evidence of their occasional presence in the resorts referred to can be shown in the mounted specimens which exist to-day as perfect as when they left the taxidermist's hands. No expert can mistake the phalaropes if he is familiar with the foot of the bird, or the avocet if he knows the bill, and in regard to the white pelican and white heron, the specimens are not only preserved in good condition, but were kept for some time at my home alive, the birds in question being secured wing-tipped by lucky shots.

Still another resting-place - and those who shot there a few years ago will not soon forget its swarming feathered guests - is the beautiful Rond Eau harbor, on Lake Erie. Here a grand land-lacked 
expanse of water, connected with Erie by the narrowest of navigable channels, extends inland like a great, almost circular pocket. Between it and the lake are miles of narrow sand-bars, ideal coursing grounds for Charadrida and Tringine, and ringing the open water are belts of rice and rush, broad and fretted with lily-laden channels and spangled with shallow ponds, beloved of Anatina. Beyond the marshy borders stands a semicircle of forest growth of varying size, where, underneath great elms, currentless creeks choke in sheer laziness with lily-pads and varied weeds and form delightful retreats for wood-duck, teal, and rail. The soil of this forested part finally becomes dry and elevated some distance from the harbor, but in the main it is moist and black and fat - the kind best of all suited to King Woodcock's taste.

A list of the waders and swimmers of interest to sportsmen, which were regularly or occasionally taken at Rond Eau, would give a good idea of what a magnificent shooting-ground the place formerly was, and it must be borne in mind that a number of varieties haunted the place in clouds.

Sportsmen will readily understand what such a varied game-list implied, and as it was as true of Toronto Island and Lake St. Clair as of Rond Eau, and possibly also true of Long Point on Lake Erie, it may be safely said that these four localities offered in the past the finest mixed shooting in all Canada. But, alas! the glory of nearly all has departed. Long Point and the best grounds of Lake St. Clair are strictly preserved, Toronto Island has met the fate of all such grounds within sight of a city, and 
Rond Eau, though still affording a certain amount of shooting, has been practically ruined.

For plover, curlew, and kindred varieties, the best season for sport was toward the close of May. "Black-hearts" and such feathered dainties usually put in an appearance about the twenty-fourth of that month, and a week of capital shooting was almost certain to follow. A description of one of many outings at the Eau will illustrate the fun we had.

Larry - a comrade for the trip in question - and I were bank clerks then, and enjoyed few holidays. On the twenty-third of May we held earnest conference. The twenty-fourth was the late Queen's birthday and a national holiday, when no good Canadian would deign to toil at any price, or do aught save what pleased him best.

We decided to drive twelve miles or more, to the bar of Rond Eau harbor, and see and shoot what was visible and shootable while going, while there, and while returning. The road thither was in excellent condition; so a trap was ordered for some time before daylight, and other preparations were speedily completed. We started at gray dawn. In the trap were the twelve-gauges, securely cased in oak and sole leather, respectively; a bag of oats for our steed; a plentiful supply of grub and shells for ourselves, and our waders and oilskins. Luckily we were given a good nag that pulled us along at a spanking clip.

What a drive that was! Two weary drudges let loose for one brief day to revel as they pleased! It was a perfect May morning, and we bowled along between farms apparently unending, where vaguely 
defined, mist-laden fields spread away to seeming boundless space. The great slumbering world paid no heed to us, for the signal-fires of coming dawn yet flared redly in the east, and even farmers and their dogs and fowl snatch sleep at times. It was good to just sit in the trap and bowl along, sniffing the wondrous spices of spring in the air, and watching the light gain power and the mist-curtains roll away. Long ere we had traversed the great clearing of farms, lances of yellow light flashed from the east and clove their way through mists and shadows and roused a myriad lives to hail the sun.

Birds appeared like magic, and rills of sweetest song bubbled and jingled from every copse and cover, telling the joy of the fresh-green, flower-spangled world. Big grackles, with black wedge-tails twisted awry, rasped and "Ska-arred" as they flew heavily from fence-post to twig. Starlings, with ebony coats and ruby shoulder-straps, queried "Cheer-cheer?" and voiced their musical "Konk-re-lay," a bird yodel of strange sweetness. Meadow-larks buzzed to and fro in brief, straight flights, and sent long-drawn whistling questions to each other. Bobolinks, in half mourning of creamy plush and velvet black, hung overhead and drifted o'er the fields, gushing forth golden cascades of song, as though the marvellous artists had stolen and blended the ripple of waters, piping, fluting, and the jingle of sleighbells into one tangled braid, and were trying to say "Whortle-berries" through it all as fast as possible. Bluebirds, sparrows, swallows, - all were there, singing as though their wee throats would burst with gladness, or gliding through scented airs at will. 
Staid robins bounced along the grass in measured hops, and now and then a liquid fluting and a flash of orange and ebon betrayed the Baltimore.

In time we reached a portion of the road where ancient woods opened but a narrow track for our passage, and where great trees locked arms above our heads. Banks of blossoms, like lingering drifts of tinted snows, were piled in careless masses here and there, and from the cool, moist shades came breaths of incense shaken from tiny censers swinging above cushions of moss and from drooping boughs. Once a scarlet splash, against a wall of green, rested a moment, like a cardinal flower, then darted into friendly cover - the first tanager.

In time the silver of Erie's restless breast flashed in front, and we drove down to the wet line of ripples upon the sand, and thence for miles along the beach, to where the sand-spit narrowed to fifty yards, and the Eau lay on our left and Erie on our right, so near that one might cast a stone from one to the other.

A rough little fishing-shanty furnished temporary shelter for our weary horse, and he was soon made comfortable. Then we lifted out gun-cases, shells, and waders, and prepared for sport. While Larry was changing his foot-gear I unlocked the oak guncase, and had barely got the "twelve" together when a storm of "black-hearts" drove down on us, flying but a few feet above the water. I had just time to shove in one shell, and as they passed about twenty-five yards distant, I stopped a few and proceeded to gather them up. When I returned, Larry was hot all through. He had forgotten his keys 
and could not open his fine sole-leather gun-case. It seemed a shame to cut the case, and we debated upon the possibility of both using my gun, turn about.

A moment later the question was settled. Chancing to glance lakeward, I spied a wavering dark cloud, not unlike the smoke from a steamer's stack. "Larry, look! Curlew, by all that's glorious!" Larry's knife was out, and he was down on his knees carving the prized leather case in ten seconds, and he couldn't cut the tough leather fast enough. Finally he got out the gun, and we walked along the sand-spit, one following the edge of the Eau and the other that of Lake Erie. We did not care for the "black-hearts" and little sandpipers, but with the larger plover and curlew it was another story.

Birds were astonishingly numerous, coursing over the sand ahead and driving along its shore line in scattering bunches; but at last we had thoroughly roused and driven most of them away to the bars beyond the impassable channel which connects the harbor and the lake. This fact worried us not a bit, for sooner or later they were bound to come trooping back, for we were on the best feeding-grounds. Our clothes matched the sand beautifully, and we lay down about fifty yards apart, where some short, dead stuff furnished the little cover required.

We lay and smoked and talked across to each other in lazy comfort, enjoying a sun-bath and keeping an erratic lookout for any stray curlew. A "robin-snipe" undertook to pass over me, and I pulled him down, for his kind are rare in that 
locality. Then Larry got four or five chances at passing pairs of black-bellied plover, and knocked the big fellows over famously, much to his satisfaction, for they are good birds.

At last a double gun sounded from the direction of the bars whither we had driven the flocks, and soon an irregular fire proclaimed that others were busy, and that our fun would shortly begin. We lay low and waited, and soon the advance guard appeared. At first in scattering flocks, then in one long procession came waders of many varieties, and we took reasonable toll of the finer sorts.

All this time we had seen nothing of the wishedfor curlew, but at last Larry hailed me and pointed lakeward. There, sure enough, was a distant cloud of birds, and I moved over to the lake side of the bar and lay down to watch. For how long we lay there staring out over the shining expanse of lake I do not know, but we had distant vision of a tremendous flight of curlew, all apparently bound for resorts on Lake Ontario. Dark cloud after dark cloud, like puffs of smoke against the distant blue, showed, passed, and vanished, as though following some selected route, and it seemed as though the curlew had utterly forgotten the existence of our tempting bars. While we watched, uncounted plovers and sandpipers flew over, or in front of, or pitched behind us near the place I had forsaken, but we had enough of them.

It has been truly said that naught can escape a patient watch and vigil long, and our turn came at last. Low down and far away over the water we saw a dark, writhing, changing line that veered and 
tacked from left to right, but grew plainer every instant.

"Here they come right for us - flatten out and wait!"

Nearer and nearer they sped until we could catch the faint music of five hundred whistling throats. Louder and louder grew the clamor till the air seemed to quiver with a storm of "Whewew-whew-whew-ew." When the long, droning, quavering, blended cries struck like a cascade of noise as though the fowl were tonguing in our very ears, we leaped up. Almost over us was a cloud of screaming birds, brown of bodies and as large as pigeons. We gathered in nine shapely prizes with stilted legs and long-curved bills like sickles.

Straightway we hunted for slim, stiff weed-stalks to hold the birds' necks in lifelike position, and soon half-a-dozen decoys were in proper array. For two hours longer we waited, and then a pair stooped to the decoys and were promptly attended to. Half an hour later another great flock clamored in, to pay tribute to four barrels. Then again we lay and watched till the sun told us it was late afternoon. In the dim distance other flocks followed the hosts that had passed, but no more came our way, and Larry finally arose and in a loud voice informed all fowl within earshot that he was hollow all the way through, and would eat or know why.

We tramped the long way back to our trap and got out the lunch and fed, feeling at peace with all the world. Then we had a comfortable smoke, and after that smoothed our birds, stowed guns in cases, and placed all in the trap. Larry led the nag down 
to the water and a few minutes later he was hooked up, and I sat in the trap holding the lines while Larry loaded his pipe.

I have heard men groan under stress of mental and bodily anguish or bitter disappointment when they put their souls into their work, and there was no fooling; but I do not think that I ever heard one single sound in which sorrow, anger, disappointment, and general disgust were so powerfully blended as in the voice of Larry as he exclaimed, "Oh, murder, look at that now!"

I turned on the seat and glanced hastily along the sand-spit we had left. There, in great fluttering clouds, in hundreds - nay! thousands - were the curlew we had seen a-wing during the day. Every one, apparently, of the many distant flocks we had longed to be within range of had changed its course and headed for the Eau bar. On the very spot where we had lain so long were curlew standing, while above them hovered fluttering hordes; and on-coming flocks were visible stringing far out over the lake. In time they all pitched and formed a grand army of curlew, such as we had never dreamed of seeing. Could guns have been hidden within range of them, and four barrels emptied in the mass as the birds rose, a world's record for curlew would surely have resulted. We could do naught but look, and look hard, which we did while thinking unutterable things.

"By all the confounded luck that ever two duffers endured, why didn't we stop there an hour longer?" asked Larry. "Why, great Cæsar! we'd have downed a hundred at least, if - "I interrupted him 


\section{Beach Combers}

by speaking very crisply to the horse, and we sped away. The near wheel bumped savagely over something ere we had covered ten yards. What that something was I did not care, nor did I look to see, but I fancy it must have been Larry's terrible - the always terrible "If." 


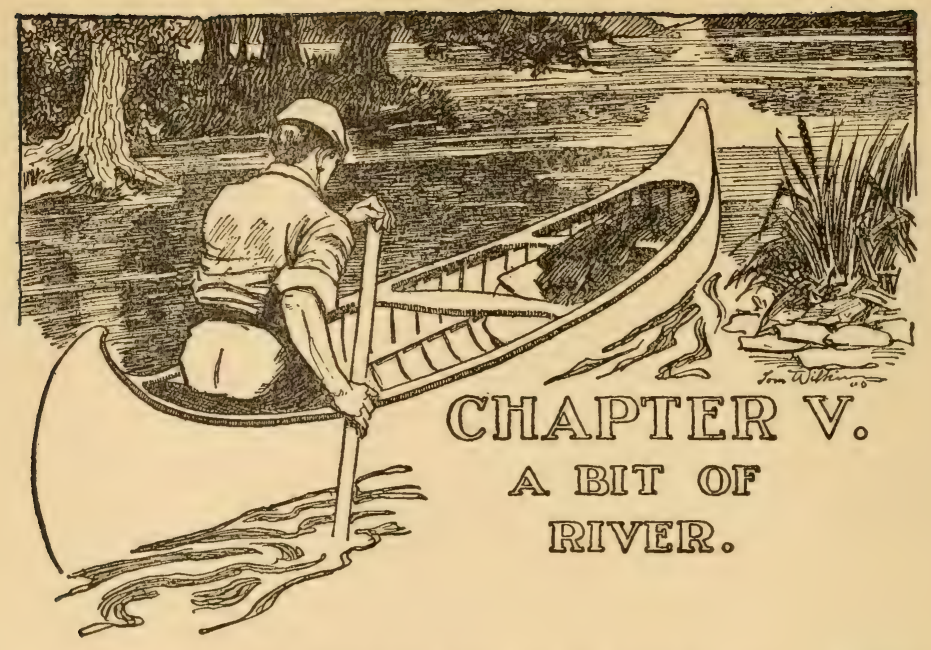

'Tis a far cry from end to end of our river. Starting in a birch canoe from where the young stream first gathers volume to float that dainty craft, one may cruise for more than two hundred miles before sighting the broad lake into which our river flows; and while yet a dozen leagues from the lake, one will find the erstwhile puny stream to change into a goodly waterway. Here it is a fair rifle-shot from bank to bank, while beneath the canoe lie twenty feet of cool, green glooms.

Perhaps few have gazed into the cradle of this river. Far inland, where the rock crops out upon the rounded hills, spreads a long side-slope closegrazed by nibbling sheep. At the foot of this slope rises an abrupt wall of clay, riprapped by nature with round white boulders. Above the wall roll long waves of ancient forest, their green surf swinging to and fro along their airy coast-line. Near one end of the wall and screened by spreading branches is a shallow pool. A glance at it will detect traces 
of man's labor, for a damp spot has been shaped into a reservoir for benefit of thirsty beasts.

All above this pool seems dusty dry, yet a keen eye can detect a tiny white furrow extending from the pool to a clump of willows at the end of the wall. Does anything other than surface water ever fill this furrow? Ask those five points of flame which mark the furrow's course; the cardinal flower knows the secret of the stream. Follow the furrow to where it enters the willows, part their tangled fronds and - Flip-flap! whew-ee-ee-ew !

A woodcock. Always one woodcock herenever more. Shoot him, and you may knock over his double at every subsequent visit, though there does not appear to be another suitable haunt within two miles. Why he never has a wife to share his retreat, or a friend to visit him, nobody knows.

Here, in the centre of the willows, lies a yardwide basin of moist black loam, which never is drier than you see it. In the spring it broadens to a pool, which at midsummer, may have shrunk to a mere damp spot ; yet it never actually dries. August's sun may curl the willow leaves and sear the hillside grasses, but this spot under its leafy dome ever maintains its cool moisture. White splashes all over it and innumerable holes bored in its plastic surface prove the woodcock's presence, for which there is good reason. If you wanted bait when it was scarce elsewhere, and turned up one spadeful of that black stuff, I'd warrant you'd find worms a-plenty. The big-eyed woodcock knows.

Nor does the friendly care of the willows above keep the spot moist. Yonder a tuft of fern and a 
clump of dock leaves conceal a willow root. Put a hand under that root - startlingly cold in there, is it not? Under the root is a wee cavern no larger than the crown of your hat, its bottom the whitest, finest sand. If you wanted a drink and had the hollow stem of a weed, you might suck up your fill of the purest water; nor would there be danger of exhausting the tap, for in that tiny cavern is born our big river. Farther it does not extend; all above is bone-dry.

How may one know this trifling cavern to be the source of a river? Easily enough. Our baby stream surely is born here, but he is somewhat of an improvement upon the ordinary run of babies, inasmuch as he is very silent and retiring. From this, his parent pool, he slyly creeps through an underground crevice to the riprap of the wall. Crawl along the wall, put an ear to the boulders, and you will hear him gurgling and whispering over his hidden play. He seems to be having rare fun in there, for the only sound he makes is like the ghost of a laugh. By ear you may trace him to the end of the wall.

Here in the sunlight smiles a larger pool, perhaps two feet across, and a trout pool in miniature. The rock ledges about it are some six inches high; the green growths stand a foot or more; the rock boulders are marble-like in size; the fall at the outlet might measure one inch, yet you see everything which lends the charm to the big trout pool one hundred miles below. The tiny fall has its whisper of song, its trace of snowy foam. If we could magnify one hundred times and in true proportion 
every feature of this absurdly small scene, we should behold something very like the great forest-bordered, rock-ribbed pool so many miles away. Then our gallon or so of amber water would be a darkly deep expanse, our insignificant green stuff stately trees, our wee ledges and marble boulders picturesque shelves and time-worn masses, our whimpering over-trickle a roaring cascade, with tumults of shifting spume and streamers of glittering bubbles. The small pool and the great have been formed by the same means and in the same way. Could we so place ourselves so as to be able to scrutinize the larger pool through a powerful glass, reversed, the picture so reduced would be this first pool where the baby river steals forth to brave the sun.

From this pool our river's erratic course is plainly defined. First, a thin line of green amid sun-browned slopes; lower down, twin green lines, farther and farther apart, till they reveal flashes of water between; a bulrush here, a willow there, with docks and lush growths thick below, till a foot-broad stream curves into the kindly shadow of the woods. Hidden springs have feebly aided our river across the sunny open, and at the edge of the woods a sturdier ally joins the onward march. From under the mossy roots of a giant maple rises a purl of liquid melody, and immediately below our river welcomes his first important tributary. At their confluence is a quite imposing pool, fully as broad as a foot-bath and at least six inches deep.

The old water-spider finds her trip from shore to shore to be something of a journey, and she narrowly 
escapes being drawn into the wrathful six-inch cascade below. Let us turn over a pebble, half buried in the damp mould, and see if there be not a red, hairlike worm under. He is in the stuff sticking to the stone. Now let us drop him into the pool - it's a trifle rough on the worm, but the true quest for knowledge knoweth not conscience. Did you see it that small point of light which seemed to flash from nowhere in particular and to lose itself - and the worm - in some mysterious fashion? Now is our river indeed a living stream, for that tiny flashing thing was a trout. An inch-long, fairy fry was he, but a trout for all that, with his full share of the headlong dash and courage of his noble race. Can he be taken? Nay! we could not find him in a day's careful search, and such elusive morsels are not to be grasped by hand. Hook him we could not, for while he might bunt at a bait, the hook is not made for those microscopic jaws.

From here our river must journey on alone. We have seen its birth and a something of earlier growth, and we shall again see it one hundred miles to the westward. It will traverse this winding corridor of greenery where the tanager and the cardinal flower glow like guiding lights; where the water-thrush rocks like a toy mandarin upon mossy boulders; where the sly mink prowls from pool to pool; where the laugh of the crested flycatcher and the wail of his lesser relative help to drown the hum of wild bees and the summer drone of insects innumerable. At the farther side of the wood sings another tributary stream, and our river glides on and on, gaining volume from many sources as it goes, till at last it 
plunges, shouting in reckless power, into the great trout pool.

Thus far it bears itself as the strong, riotous child of rocks and hills, but not far below the great pool its character changes. Left behind are the pomps and vanities of rollicking falls, gemlike bubbles, and foamy wreaths. Left behind, too, are the rocks and sudden steeps which tempt a woodland stream to daring plunges and merry racings. Henceforth its course winds through fat lowlands, mighty forests, and broad clearings; thence through leagues of fens and marshes, till at last our river, now slow, deep, and wide, finds its long-sought lake.

When it left the rock lands - the region of evergreen-clad slopes and maple-filled intervales - the river bade farewell to its trout. No jewelled aristocrat could tolerate the long, lazy reaches of almost currentless water, the weedy margins, the slopes of clay, down which every summer shower sends yellow cascades to stain the languid flood for hours after. The trout reigns in the upper waters, where the cold springs pump unceasingly, where the water knows no rest, where new-born insects try their wings and clumsy larvæ slip and fall from lofty twigs. There, like ancient robber of the Rhine, Sir Trout holds his own by prowess and lives by the right of might.

In the lower river are many fishes - so many that the absence of the trout does not greatly matter. The deep placid water suits numerous species which never seek the upper stream except to spawn, and even then never penetrate to the haunts of the trout. Any angler of the lower river will tell you that it is not all, or one-half, of fishing to take trout. $\mathrm{He}$ 
has muskallonge, wall-eyed pike, pickerel, several species of bass, mullet, carp, perch, drum, dogfish, catfish, garpike, and others for his special amusement. Of these he takes great strings and enjoys greater fun, for he is the true angler. He may or may not take bass with the fly. He can do it, if so inclined, for he knows fishing from gill to caudal. $\mathrm{He}$ is wise in the matter of baits, and has as many as the trout fisher has flies. He knows where, when, and how to take one and all of his prizes; how to keep in condition the fattest minnows; how to coax worms to the surface during hot, dry nights; how to secure the crayfish, the bee-larvæ, the white grubs from sod or rotting logs; how to best use the small frog, young mouse, grasshopper, cricket - in fine, how to use everything capable of tempting a fish. He also knows exactly what to do with tempted fish.

These bait fishers are apt to be the shrewdest students of fish-lore, for to be successful one needs must be well informed. While the trout fisher exercises much skill both in casting his lures and playing his fish, yet he has comparatively few details to master. Once he has learned how to use his tackle and to recognize good trout water, he is upon the highway, or waterway, to success, for he is after but one variety of quarry. The impetuous dash of the trout also simplifies matters. With the bait fisher conditions are very different. He may be intent upon the capture of specimens of half-a-dozen species which differ in habits, haunts, and food. During one day he may be compelled to employ several distinct methods and many varieties of bait, and be it known that an intelligent use of bait 
demands as much skill and vastly greater all-round knowledge than does fly-fishing. This, to some, may appear rank heresy, yet it is true.

Of course, in this class of expert bait fishers are not included those cheerful idiots who select a spot because it is shady, or offers a comfortable seat, then plop in the bait, set the pole in a crotched support, and perhaps read, while waiting for something to happen. That, beyond question, is still-fishing, also beautifully restful. A comical feature of it is that every now and then it proves partially successful, for even a duffer may blunder upon the proper spot at the right time, while almost any one knows enough to heave upon a fish-pole when the signs say that something has managed to hook itself !

The real bait fisher, however, would scorn so lubberly a method, and by bait fisher is meant the man who fishes the river, instead of some six square yards of it. He knows every bit of good water for miles, where to expect each species of fish, what baits to use and when, and what to change to should a sort usually tempting happen to fail. His method somewhat resembles the fly-fisher's, for he keeps moving from one promising spot to another, and if any one catches fish, he is apt to be the guilty party. And this sort of fishing is the more interesting because it affords both variety and full scope for the exercise of one's craft, for it calls for something of the observation and resourceful skill of the stillhunter, rather than the putty-like patience of the ordinary still-fisher. Among the experts of our river are past masters of this branch of the gentle art. The great charm of our river, however, does not 
of necessity have scales on it. While fish certainly have much to do with the pleasures of fishing, still the surroundings are important factors in rounding out the charm of a day's sport. A glance at a threemile stretch of the river should give an idea of the typical surroundings.

At the starting-point the stream is eighty yards wide and about twenty feet deep. Near either bank extends a bronzy-green mat of trailing growths, grasses, lily-pads, with here and there small belts of rushes and reeds. Owing to the level country, the river's course is very erratic, and if we follow one bank, we find a shallow and a deep channel alternating at every bend. One side filling up, the opposite cutting away, is the rule, and the graybeards know that at many points the river once ran one hundred or more yards from its present bed. Many a noble tree has been undermined and swept away when the spring floods came down.

The banks vary at every bend. At one they are almost sand-flats; at another, easy, well-wooded slopes; at yet another, soft curves of richest green, swelling up to the farms above, and next to these are miniature cliffs of yellow, sandy clay. Not seldom two of these types are opposed, especially the low flat and the cliff-like formations, which prove how the river deposits and cuts away. The vegetation presents a rich variety. Here towers a mighty sycamore, its grand trunk sheathed in silver mail, its strong arms stretching far to slender twigs, from which the oriole swings his hammock. In vain does the bare-footed urchin longingly eye that treasure pouch - the glistening bark is treacherous, 


\section{$A$ Bit of River}

the river waits below. For how long has that grand old tree remained on guard? Older than the civilization it overlooks, the tooth of time has bitten deeply into its upper trunk. The wolf has howled at its foot when the sand bore fresh imprint of the deer's dainty tread. The canoe of the savage has drifted beneath those limbs and startled the wild turkey from its lofty roost, yet the old tree stands firm. Now the red-headed woodpecker bores where the sap has ceased to flow, the purple martin and white-bellied swallow wheel at will about the round black holes, and flocking grackles rest awhile before the last long flight to the distant marshlands. Year after year one hundred fledglings have loved this tree as home.

The sycamore has goodly company. Broad, leafy basswoods, far-reaching Norway maples, paletinted butternuts, rich-wooded walnuts, rough chestnuts, shivering willows, dark-looking mulberries and elms, shapely maples and oaks, are ranged in stately columns. Below them crowd alders and ferny sumachs, among which blaze the golden stars, dear to country maids. In places, too, the vines run riot. The creeper trails its graceful length from many a limb, the wild grape's tough rigging stays a hundred living masts, and the clematis bursts its smoky balls till they hide the bushes in hazy clouds.

Well do the birds and small beasts love such sanctuary. The morning chorus swells with the voices of many species. The kingfisher rouses his rattle and drops like a plummet upon his prey. The flicker enjoys his airy canter from trunk to trunk and shouts his lusty challenge to following 
friends. The sandpiper curves outward from his strip of beach while his trembling pinions seem to shake from them his sadly sweet refrain of weet-weetweet-how-sweet. Big grackles, with tails awry, cluck gruffly in homeward flight, or, perching, raise shoulders and rasp out their metallic greetings. Where the willow's rotting stub has shrunk turtle-like within its outer shell, the dainty wood-duck hides her ivory treasures till downy fluffs of wild life are ready to be carried to the kindly stream. Sedate old robins bounce across the green and shape their cottage mud-walls so near the path that the prowling urchin scorns to harry such easy treasure. At dusk and dawn, from highest twigs, the thrasher fills the air with difficult passages from bird classics, while from the scrub below, his slaty cousin, the catbird, flirts his nervous tail as he mocks the feathered star above, or renders an original selection to prove that he, too, is worthy the name of minstrel.

Above, where the hay-fields warm in yellow sunshine, the bobolink loiters on ebon wing, while his tinkling cascade of liquid notes need but a slight effort of fancy to be transposed into a silver tributary of the river. Under the denser growths, the towhee scratches among the dying leaves, while now and then a note, fuller, richer, than all, floats up from nowhere - as though the spirit-hand of some great master had touched again his sweetest chord. That rare brown poet, with spangled breast and soft dark eye, speaks from velvet shade straight to the heart. Only the wood-thrush has mastered the witchery of musical brevity.

There are many others. The caress-like pleading 
of the bluebird, the sharp, insistent exclamation of the yellow warbler, the cheer-cheer, or cadenced fluting of the redwing, the low contralto of the cuckoo, the exquisite, though sorrowful plaint of the dove, the well-beloved tinkle of the song-sparrow, the better-rounded effort of his gifted cousin, the white-throat, the hiss of the cowbird - these do not exhaust the list of performers, but are they not enough to entitle our river to rank as a river of song?

The banks, as banks should, hold treasures. Where the feet of cattle have printed the sand flats, lie pear-shaped eggs, seemingly twice too large for the sandpiper which guards them. When those eggs shall have warmed to life, we may find stiltlegged, downy youngsters, still guarded by the trim, everlastingly nodding mother, who, with all her melodious pleadings and silly curtseyings, knows quite enough to simulate lameness to tempt an invader. Helplessly as she may flutter, and aimless as her crippled efforts may appear, they always lead away from the sand-matching young. Pursue her, and the sweet farce will end the instant she considers the young safe.

About cliff-like banks hovers a cloud of martins, forever entering and leaving their clustered tunnels. Do they ever become confused and enter the wrong openings? It is unlikely. You, unless you were club-confused, might be trusted to find your own house in a row of similar houses. The martins are even more clever, for they never hesitate, look for a number or mark - they simply fly straight home and creep in at the one hole in the colander-like 
arrangement they care anything about. Thrust a hand far into a burrow and you may feel the wee, snowy eggs softly bedded in goose feathers looted from far and near. If the bird be at home, you may feel her tiny mandibles nibbling feeble protest at your fingertips.

In a quiet nook of a higher bank, where overhanging sod and roots form a generous eave, is a larger burrow, the home of the kingfisher. Never mind about putting your hand in there. In all probability the burrow is longer than your arm; and if not, Alcyon can bite, and she will not hesitate over using her fishing-gear in an attempt to teach you better manners.

At one mile-long reach, where the river, for once, manages to keep straight, the scene rises above ordinary beauty. It presents a superb corridor, domed with richest blue, walled with living green, and floored with flawless crystal. The trees rise straight from the water's edge, and only at midday can the sun strike fairly upon the waveless flood. During early and later hours the shadow of one mass of trees stretches almost, if not quite, to the foot of the opposite wall. This is a paradise for vines. Creepers, clematis, ivy, and innumerable grape-vines so bind together trunks and branches that, in a breeze, the whole sways like a single growth. The squirrels revel in such a magnificently appointed gymnasium. Long tight-ropes, great swings, handy loops, and rings are there for every furry athlete, and they seldom are idle. Such balancing, daring runs, bold swinging, and reckless leaping as go on there cannot be surpassed outside a tropical forest where 
the gargoyle of the human athlete, the monkey, holds undisputed sway.

Nor does our river lose its charm upon the death of the day. The most brilliant songsters may become silent, but the night creatures are active and interesting. If one drifts between the darkened walls in a canoe as the harvest moon peers across misty fields, he will hear much that is worth hearing. The leaves hang motionless, wearied of allday dancing. The water spreads like oil into black, uncertain shadows. The trees upon one bank stand like silhouettes against the growing light, while the opposite foliage brightens with countless silvery flashes.

From bank to bank wages Cicada's endless dispute over Katy's alleged indiscretion, interrupted every now and then by a bellowing "B'ject!" from some lawyer frog who fancies the prosecution is transgressing. A long, hissing fall, ending in an explosive "Boo-oom!" tells where the night-hawk is playing in the moonlight, while his cousin, whippoor-will, sobs for satisfaction from every dusky point. High above, a singing of wings betrays the course of a party of belated wood-ducks, and a pair of great horned owls prolong gruff throaty argument over the affairs of the night. A startled killdeer makes musical protest against some unknown intruder; a sandpiper takes up the case as a family matter, which rouses a sleepy sparrow, which, from sheer force of habit, tinkles a thread of song ere again dropping off.

A broad-fanned gray heron questions another ghostly form regarding the fishing farther up, and 
a few sociable raccoons are holding a clam-bake at the rear of a quiet cove. Muskrats are busy trading from port to port, while some, more adventurous than their brethren, go gravely steaming in the open and plough long, silvery furrows to distant shores. Fish are constantly leaping, and the trained ear can detect the nervous upward shoot and sounding fall of the flat-bodied bass, the lazy, oily roll of the catfish, and the sharp strike of the lance-like pickerel.

The canoe makes no sound to interfere with one's observations; in fact, the rasp of the Cicada is an uproar in comparison with the velvety slide of the silent craft. From start to finish of the voyage attentive ears may catch secrets from air, tree, and water, for nature is forever tattling to those who have learned how to listen. Through all the varied night voices thrills one mysterious note. The water seems to quiver with it - it never varies, and it apparently comes from directly under the canoe. Miles make no difference to that low, unvarying grunt - the endless drone of the fresh-water drum. 


\section{CIIAPTIRR VI。 \\ TIIIE IISIIING (OIF \\ TILIE FRIEE TFOLR。}

IT may appear crude, this fishing of the Free, but in reality 'tis as smooth as the favorite waters, and not seldom a deal deeper than the casual observer might suspect. Because it lacks the action and tinsel of the so-called higher forms of the art, it rarely receives attention from those wizards of pen and pencil who have made the fame of the fly.

It is true that its bare-footed exponent might be unable to deliver an address upon the why and wherefore of the many curious things he does, but he catches fish, which, after all, is about the limit of the most scientific possibilities. The typical fisherladdie of fresh water is a peculiar small chop with a wise little head crammed with all sorts of scrappy information. He himself never could tell where he obtained the half of it, yet he has it, and he knows how to use it.

It may be he sees a grub fall into the water, and a sudden swirl suggests that some unknown fish took that grub. There may or may not have been time to identify the grub; but one thing is certain, - the grub could not fly, hence it must have tumbled from the foliage above. Our laddie, being a barefooted, agile varlet, can climb, or go where he wills, and presently he discovers a grub, the like of which 
he never had noticed. Upon his hook and into the water where the other fell it goes, and because the fish is lurking near by for just such another windfall, there presently is something doing.

"Got a new bait for bass," or whatever it is, says the boy to himself, and he searches for more grubs.

The fish of the free folk in question include the large and the small mouthed black bass; the rockbass, or red-eye; the crappie; the calico-bass; the sunfish; the white bass; the yellow perch; the pickerel; the wall-eyed pike; the sauger; the bullhead; the catfish; the drum; the dogfish, or bowfin, and the garpike.

The tackle of the free folk must be either the long handline, or the shorter and finer cord which is attached to pole or rod. A thirty-yard handline would be a very fair length, and it appears to lie naturally on a reel carved from a portion of a shingle. It is not wise to merely wind a long line upon a bit of slim stick, for the inside of the ball thus formed retains moisture which soon rots the line at the very worst place, i.e. near the shore end. To the other end is made fast the sinker, which must be just heavy enough to nicely carry out the line and no more. Too heavy a sinker is a clumsy drag when one is pulling in, and it makes too noisy a splash when sent out. The ker-chug of too much sinker will cause one of the free folk fifty yards away to turn his head and grin derisively, and, possibly, he may sweetly inquire why one doesn't tie a brick-bat to his string. He himself would cut a short length of alder half an inch in diameter, punch out the pith till the inside was clear, stick the little tube into some 


\section{The Fisbing of the Free Folk}

sand, melt shot or scrap lead in a big iron spoon, and pour it into the mould. The hook is a most important point. It must have a well-rounded curve, and if the barb has a twist to one side, so much the better. It must have an eye. To the free folk, the eyeless hook is an invention of the Evil One, and no free fisher is blind to the material advantages of an eye. A hook having an eye can instantly be made fast as desired and the entire shank be left free for bait. Any one who knows anything understands that a length of fat worm slid up the shank is a heap better than string, knotted or wrapped, so there you are. The sinker being at the end, the hook, or hooks, must go on above it; so they are attached to foot-long lengths cut from the line and tied to it where wanted. If the lower hook hang a foot above the sinker, and the upper a couple of feet above the first, they will be about right. Usually, the free ends of the short lengths and the line proper are together looped into a hard knot which cannot slip. Sometimes, and it's no bad way, a hard knot is made at the end of the hook tackle, which is then passed through a single knot in the line. This, once drawn tight, will hold like a vise, yet may be worked loose when desired by a trifle of judicious picking.

The casting of this tackle is very simple. For short distances the line is held just above the upper hook and tossed where wanted. When it is desirable to get out a lot of line, the same hold is taken and the sinker whirled a few times before the cord is released. Nothing but practice can teach just how hard to whirl the lead, and when to let go, to insure a long, smooth cast. An experienced hand 
frequently sends the line out the first time to straighten kinks and get it wet, then recovers it hand over hand, letting it fall upon itself in easy coils, then baits and sends it out for fish.

The rod or pole outfit is preferable for streams in which the water is deep near the bank; indeed, many boys esteem it above the handline for fishing. Because the average boy cares little for, or cannot afford, a fancy rod, that article need not be dwelt upon. Cheap jointed rods are a nuisance, and neither so good nor so satisfactory as a springy cane, or a trim, wiry pole cut by the fisher's own hand. The line should be about twice the length of the pole. It is best made fast near the butt, then carried with a few turns round the pole to the tip, and then again made fast. Thus rigged, a broken pole does not necessarily mean lost tackle, or even a lost fish. Many boys scorn a float, yet it is a very useful thing. An old cork split half through is away ahead of a store float. It can be attached or detached in a moment, and as easily shifted along the line; it costs nothing, and cannot be very well injured. The sight of a cork tied fast crosswise of a line is a hint of greenness which no free fisher will fail to observe.

The actual fishing of the free folk is a thing so subtle, yet comprehensive, so broad, yet full of detail, that it is not to be speared offhand by a smooth-nibbed pen, nor marshalled into serried columns of hard-featured type. It is, however, possible to follow even an active boy's erratic trail for a few miles, so let us attempt the task.

It is a flawless morning, and the air is rich with the magical sweetness of the spring. In garden, 
copse, and wood everything is thrilling with new life and song.

It isn't altogether laziness which keeps me dawdling over breakfast till the clock marks half-past eight. Too much hurry is a serious sin, especially in connection with fishing. It is all very fine for some folk to prate about "gray-dawn starts" and unholy things of that kind; but the fact is, one seldom takes any fish worth taking very early in the day. My experience goes to show that from about ten till noon, and from about four till sunset, are the best hours of the twenty-four for the sort of fishing herein referred to. Later in the season it might be worth while to get to work soon after sunrise; but that is another matter.

Because there has been a lot of recent digging about the grounds, the big bait-keg contains hundreds of fat worms well covered with moist earth, so the filling of the bait-box is a simple matter. But, all unsuspected, there is an ordeal to be passed. Crouched at the gate, his quivering nostrils emitting a thin, wiry whining, is Don. His lemon head and snow-white body tell of the stout old pointer blood, while his strategic position indicates a thorough knowledge of what is in the wind. $\mathrm{He}$ has been ready for hours, and he wants to go. Upon the dining-room table stands a good-sized basket, and beside it, as keen and watchful as Don, stands a trim, girlish figure. Evidently she too wants to go, and, according to her custom, she has got ready before asking, and baited up the lunch-basket in a deadly way.

It is contrary to law that both girl and dog go, 
and they know it. Because no living mortal possibly can fish and keep track of a well-trained dog and a half-broke girl at the same time, he wisely leaves one or the other at home. Neither means to do anything wrong, but they invariably play the mischief when they get out together. It is true that the dog never would think of spitting on a stick and throwing it for the girl to fetch, nor would he say: "Come to me, you poor thing. I'll love you when your nasty boss is cross with you. You may run and splash as much as you have a mind to." To be candid, I think the dog would be all right, but then there's the lunch-basket. The upshot of the matter is that the dog receives a crisp order which causes him to tuck his tail and slink to the back premises, where he will sulk and hate the girl for at least twenty minutes. He will make no attempt at sneaking after. He knows better than that. But he will sit outside the gate and gaze far up the road from midafternoon until he sees two distant figures emerge from the tangle of a hedge.

But to the fishing. Because the ancient order of things was that all females should do all the uninteresting work, because the girl has filled the basket, and because she's duffer enough to stand for it, I just let her carry it. This glorious privilege is fairly jumped at. She'd gladly carry the two rods as well, but they are not like lunch. They are man's tackle, and only the lordly masculine paw understands just how they should be clutched. It is the same with the bait-box. No self-respecting baitbox ever would stay shut in any but a masculine pocket. In a skirt-pocket, it just opens and lets 
loose the worms. Why, I don't know, but sooner or later those worms will get loose, and you'll hear about every single worm. So far as I know, only women, mice, bumble-bees, and those small, jumpy grass-frogs thoroughly understand the mysteries of a girl's short skirts. It is sad, but so.

Where a couple of ancient bars mark the faintly defined path, we leave the road and pass between twin snarls of briers and saplings down to the river bank. At the end of the path is a goodly cove, deep and still dug by the chafing current, which, two springs ago, undermined the stately basswood which now lies, hugely heavy and dark, in its cool, green tomb. A black, well-like hole shows between the rotting roots and their old anchorage, and the unerring instinct of the free folk tells me 'tis a likely spot for a swart rock-bass or an overgrown "sunny."

The girl meekly places the basket upon the ground, and I make ready the rods. The lighter and shorter one is rudely ornamented with long spirals and stars cut in the smooth bark. Either I was in an unusually kindly mood, or I had just completed a shrewd dicker for a new knife when I took all that trouble. "Bait up!" I order, with the curt savageness of a chief of the free folk; but the sole response is an appealing glance from the big fawnlike eyes. "Dern a girl, anyhow," I mutter as I rapidly loop on a couple of pretty fair worms, after sagely picking over some much better ones which surely will go on the other hook. The girl makes no comment - she couldn't, for her mouth is all pursed up, and she is working her jaws like a rabbit chewing a short straw. 
"Here's your old bait - now spit on it for luck spit straight, or you won't catch nothin'!" I sternly command, and she gives a little shudder and strives to obey. None of them ever does it right. Perhaps she's afraid to hold the writhing worms near enough to her mouth, or it may be she fails to comprehend the grave importance of accurate spitting. Anyway she don't half spit, which, to a leader of the free folk who, when he had lost a tooth, could nail a bumble-bee at five yards' range, seems something like a crime. "I - I - tried my best, and I did put a little on one end," she almost whimpers; but a scornful "Umph!" is all the satisfaction she gets.

In a minute, more and better worms are adorning my own hook and are artistically spat upon. Then the split-cork float is shifted just so, and the bait is noiselessly dropped near the upstream side of the log. The cork has drifted barely a foot when it halts in a suspicious manner, goes almost under, then steadies. Brown paws clinch upon the rod; brows lower to a savage frown, and eyes glare at the cork as though they would set it afire. It is an awful moment.

"Where'll I fish? - please tell me," says a meek voice.

"Shut your head-you'll scare him! Drop your old hook-in-hole-right-front," I fairly hiss, for the free folk don't like to be bothered when there's something doing. A solemn plunk tells that her bait has gone somewhere. But my cork is nodding again. Tug-tug-plop!-under it goes, and in a moment the pole bends. There is a brief zig-zag 
resistance, then a shiny thing whizzes through the sweet air and hits the bank with a sounding wallop. I spring tiger-like upon the fish and jam a nervous finger through its gills, for it is, indeed, a mighty rock-bass, nearly a foot long, and as nearly a pound in weight. You don't take more than one such rock-bass in a week so, naturally, I am jubilant and rather chesty as I string him and make him exceedingly fast to a handy root.

"That's the way to snake a big fish!" I proudly exclaim as I proceed to bait-up. "Hank Jones 'lowed he'd landed the boss rocky last week, but his'n wa'n't a minny 'longside mine. Why, a girl could catch a bigger fish than Hank's. Why, you might do it some day, after you've learned the A B C of it. You just watch me and -"

The sentence has never to my knowledge been completed. All the girl said was, "Oh! ah! ah!" in queer little jerky gasps; but she clung to her carved pole and heaved like a navvy at a tremendous something which lashed the water into suds. I distinctly remember seeing her put her small shoe into six inches of water and not notice it; also, that she gave a final strong heave and sat backward upon the bank, and that an immense bronzy shape followed straight into her lap. It seems to me that she spread her knees very wide under her skirt, then slapped them together and folded her arms across, and bent over as though she had a pain or something. Because the free folk don't wear skirts, they never try to catch things in their laps nor spread their knees. If they had to make a try at it, they'd first get their knees together, 
then grab with their hands. It's the difference of apparel does it.

When I come out of my temporary trance I notice three things. Two of them are stockings, or, rather, liberal portions thereof, while the third is a square fish-tail, a good deal broader than my hand. It flaps a bit and curves in a straining sort of way; but it might as well take things easy, for its owner has about as much chance as a dead fish of getting free from that sadly mussed frock. When I finally get hold of the prize, I hardly know whether to feel mad or glad. It proves to be a black-bass, so large that I cut its spine near the head before daring to trust it to the string. The flush of delight upon the girl's face helps to mollify my outraged feelings, but the Old Adam prompts me not to tell it is useless to fish longer in that lucky hole. I compromise with my sense of right by really putting on a better bait, which is a bit too late to do any good. She is perfectly satisfied, and as she watches her idle float I try other spots about the tree. Two more rock-bass are soon taken; then comes a brief idle period, and, true to the creed of the free folk, I order a change of base.

Because a girl's only a girl, and somebody might pass in a boat, I carry the big bass, while she fags along behind with the two rods. She hasn't said anything about her wet foot, but I can hear her steps go pat-squiz-pat-squiz as she humbly follows. Some two hundred yards above, a few snaky-looking black roots mark another fallen tree. It is a very bassy spot, and immediately above lies a sandybottomed cove, where nobody who had any sense 
ever would think of fishing except with a very long handline. "Now, I'll freshen up your bait real nice, and you'll trot to that clean sandy place, and mebbe you'll catch another big bass. I'm sure there's one right there," I calmly remark. Good as gold and easy as a gudgeon away she goes, and I grin with unholy glee as she drops in her line and stands, rod in hand, like a pocket Patience.

My bait is barely well sunk before the cork goes under, and in a moment a fair rock-bass is flipflapping on the bank. She smiles and nods her little head, then fixes her trusting eyes upon her float. In my heart I feel it's a shame to fool her so - yet her fish is very large and fine. A couple of rock-bass, followed by a really large "sunny," are added to my score; then I try farther out, and presently hook a big drum. For a moment he feels like a bass, and I gloat, but the flash of a silvery side tells the truth. Half angrily, I yank him out, twist free the hook, and, according to the code, mash his head and secure the two lucky stones. By the unwritten law of the free folk, she is entitled to one, so I take it to her, mainly because to neglect this would entail bad luck. She is delighted, and, with due humility, she brings in her hook and asks me to please look at her bait, because she knows how superior my knowledge is of such matters. I loop a worm afresh and return to my own water. Half-a-dozen tries only raise one small "rocky," so finally the hook is brought to hand, given a turn around the butt, and I am ready for another shift.

While untying the tethered fish, I hear a sudden 
splash, and look up to see a wonderful picture. The slim, girlish figure is stiffly braced, her hat is hanging on her shoulders, her face is very red, and she is lifting for dear life. I know the rod, and one glance at its curve tells how big is the fighting captive. I hardly can believe my eyes, for, as I look, a great, green thing springs from the water and falls back amid a shower of spray. There is barely time to shout, "Stop! - you goose! - play him!" before she turns and runs up the bank, dragging rod, line, and fish bodily after her.

"That's a dickens of a way to play a fish!" I growl half savagely as I unhook the biggest bass of the year.

"I - I - don't - care - I - I - gottim - anyhow!" she gasps, and I have to laugh in spite of myself.

But the blood of the free folk is mighty near the boiling point, for nobody ever took a bass in such a spot, and nobody but a chump of a girl would try to.

"It's the 'lucky' you gave me," she says softly, "and the lovely place you let me have. Next time you must have the good place."

Something in her rosy color and shining eyes checks a fierce impulse to chuck her bodily into the river, and the angry pride of the free folk humbles itself. At the next good spot she gets a fair chance, and at this and others small fish are added to the string. At last she seats herself upon a log and remarks:

"It's too lovely for anything, but we'd best eat. I've got sandwiches and pickles, and, oh! let's cook a fish - do - please," she says. 
“All right!" I reply. "S'pos'n' I fix your big bass and build a fire and cook him?"

The big eyes are clouded, and she sighs softly. But in a moment she is again all brightness. She nods merrily and says, "All right! cook him if you wish."

Of course I didn't. Had I caught that fish and some big duffer tried to cook it before I got it home and displayed it, he'd have had to whip me first, and the free folk will stand for their rights till their fish poles are worn down too small for clubs. So, instead of the prize fish, two small rockies are scaled, cleaned, and stuck upon a couple of stiff switches.

"You cook mine. I don't know how to do it like you," she says sweetly, as she busies herself with the basket. Ah! the craft of it.

Feed the brute! A half-dozen prime sandwiches backed by a fairly good rocky will bury jealousy so deep you can't find it with a skewer. There is a bottle of tea, too, sugared just right, and the last swig of it floods the sandwiches, the rocky, and my soul with human kindness. We idle over everything; the birds sing cheerily; but at last a sharp splash brings us to alert attention.

"See the ring he made. Go catch him - I'm tired," she says; and I slip down the bank, for a broadening ripple near a stump suggests that a blackbass has chased a minnow. In such a case worms may, and may not, score, and alas! I have neither minnow nor minnow-tackle.

As feared, the worms prove unattractive, but the wisdom of the free folk suggests something else. It is too early for grubs, but a crayfish might do; so I 
cautiously turn over some sunken trash. A little nipper darts backward for deep water, followed by an angry growl. She comes down, too, and prowls along the margin, her bright eyes scanning every possible bit.

"Here, quick! under this - see his horns!" she excitedly whispers, and I steal a hand over a bit of bark and press it down. Someway the crayfish wiggles into my hand, and, not having a sure hold, I hastily sweep him ashore. By unlucky chance he lands upon his back only a few inches from the water. Like a flash she grabs him and promptly shrieks, "Oh! he bites - take him off!"

A big blue claw is savagely nipping a finger, but I soon make it let go. Then the finger goes into her mouth, the hook goes into the crayfish, the crayfish into the water; and, apparently, into the midst of a bully bass. A great fight follows, but when the fish is flung far up the bank, it proves a pound lighter than her grand fellow. However, it is a fine fish - quite large enough to make one of the free folk positively genial.

The short cut homeward is easy; but wonderful is thy tact, O woman! Just as we reach the one stage where people can see us, she suddenly grows too tired to carry those fish one step farther.

Nay, reader, it is not false pride, nor anything small; it is bigger and broader than even the liberal code of the free folk, this thing which suddenly causes the sore finger to throb and the sturdy little arm to lose power. It is the stuff which later makes the self-sacrificing mother; it now prompts her to surrender the prizes, to meekly fall to the rear with 
the rods, while a bull-necked chief of the free folk haughtily leads past houses and staring eyes. Young as she is, the she in her truly tells her how dearly the he in him prizes that brief triumphal march past. And if later the scales fall from her eyes, and, a past mistress of other angling, she makes him follow, as he should, and before a heap more folks, too, I'll not blame her one bit.

"Don't you go and tell about my wet foot," she hoarsely whispers at the door. "If you don't, I won't get croupy." And lest any one should get away with a wrong impression, it's only fair to say that the bargain was strictly fulfilled on both sides. 


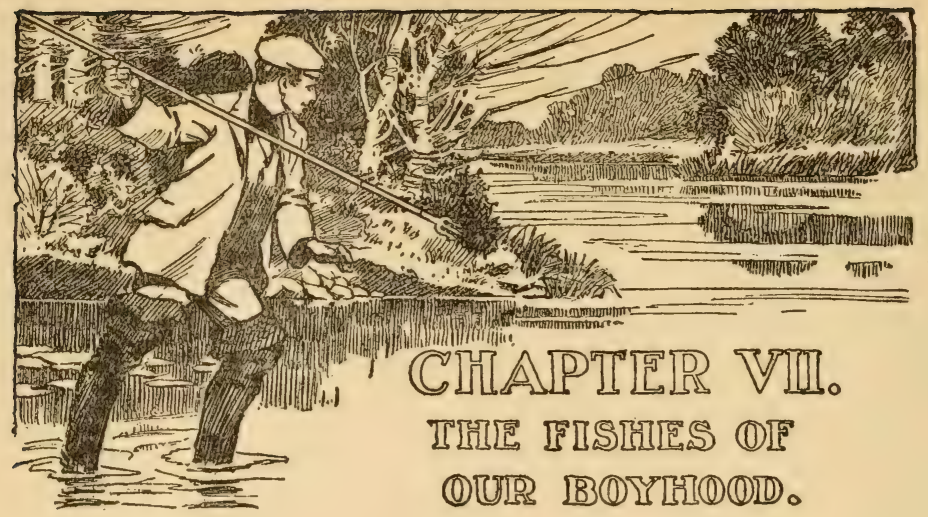

There was not a trout in our country. The region of rock, tumbling falls, and swift brooks ended miles to the eastward. But we had waters a-plenty, - deep, calm, slow-moving rivers and creeks, which took their own time about reaching the big lakes which half surrounded our territory. With the exception of the banks of waterways the country had few slopes. For miles one would not find a stone. The great levels of fat land bore alternate growths of ancient forest and bountiful crops. It was not a trout country.

Of the old crowd of boys, who knew the ways of every beast, bird, and fish indigenous to their sporting ground, possibly not one ever set eyes on a trout, until he had travelled considerably beyond the confines of his native district. What the eye does not see the heart does not crave, so we troubled ourselves not at all about the trout.

Our waters teemed with other fish. There was fishing in plenty, and good fishing at that, so, perhaps, after all we were better off without the trout. In a trout country, as a general rule, one fishes for 98 
trout and for nothing else. Not seldom the trout is the only available fish; hence the youth of that region, while apt to learn a lot about trout, remain in ignorance of a dozen other species of most interesting fish.

In our country things were different. In order to be a successful angler and so command the respect of one's associates, one had to know more or less about a dozen species of fish, as many sorts of baits, and also the methods by which the fish and the baits might best be brought into close connections. The old boys knew about these things, and many other things not to be found in books. They could tell you when, where, and why to try at a certain spot for some particular fish, and what bait to use. Then if you did not take the fish, they'd borrow your tackle and speedily prove the correctness of their knowledge.

Those were glorious old days! From sunrise to sunset, care-free; then nights of dreamless sleep. We were forever busy, on, in, or about the water. To rise, feed, and flee to the river; back, feed, off to the river, was the daily programme. We knew every foot of bank and shallow, and, for that matter, most of the depths. Where the turtles buried their eggs, when the muskallonge might be expected, when the pickerel followed the overflows - in fact the waters had no secrets. When a new boy came, as he sometimes did, with tales of the trout fishing of distant parts, we listened in mock humility. Then some one of us licked him, and if he took that with becoming knightly fortitude, we later took him fishing and so to our gentle hearts. If he chanced to 
lick one of us - but come to think of it, there was no provision in our by-laws for the impossible! When we took him fishing, he presently was convinced that what he knew about trout wasn't a circumstance to what we knew about fish.

And such fish as they were! Strings upon strings of captives large and small, tied here, lugged kicking there, by happy, sun-browned, bare-footed boys, who found no weariness in miles of wading, perching, prying along the banks - stealing marches on each other, using every resource of knowledge and ready adaptability in order to finish " high hook" at the close of the day. The boys were no minnow fishers, and few indeed were the blank days. Fine fish, up to five pounds in weight, rewarded the youthful toilers; indeed, not seldom a few plump bass stopped awkward questions concerning truancy and saved certain jackets from vigorous dustings.

As a course before the fish, two forms of life may be discussed. Both were very interesting, the one as bait, the other as an unfathomable mystery. The bait was the crayfish, the miniature lobster of fresh water. Abundant in shallow water near the banks, in creeks, ditches, and certain bush-ponds, the crayfish, at times, is deadly bait for the basses and a few other species. The boys preferred crayfish of medium size, and instead of spitting them crosswise upon the hook, as is commonly done, they forced the hook in at the mouth and out through the tail. So hooked, and allowed to sink quickly, the bait gives an irresistible imitation of the live crayfish's backward, wavering rush to shelter.

The best thing for securing such agile bait is a 
boy's deft, brown paw. The nip of the formidablelooking claws really is a trifling matter. The crayfish are found under stones and sunken rubbish near the margins of streams, and under sodden bark and leaves of bush-ponds. Crayfish burrows, capped by curious little mud-towers, are familiar objects to those who go much a-field. When not easily obtainable elsewhere, the crayfish may be taken from its burrow by overturning the mud-tower, lowering a bit of flesh tied to a string and jerking when the sure-to-follow nibbling is felt. The boys also "churned for 'em," by breaking a switch with a ragged end, manipulating this in the burrow till the outraged crayfish took hold, then jerking him from his bomb-proof.

The creature referred to as a mystery is what is termed the "horse-hair snake," in reality a hairworm. It is found in all of our waters, and it greatly resembles a black hair from a horse's mane. Most boys are willing to swear that this hairworm really is a horsehair turned into a snake, and many grown persons will back up the claim. People have declared that they have placed a horsehair in a bottle of water, corked the bottle, and kept it so till the hair had turned into a snake and swam about. Science, however, accepts no such testimony. The truth is, the so-called "snake" is a gordioid nematode worm, so named from its structure and characteristic habit of snarling itself up. Its first stage of life is as a parasite, the hair-like form representing the adult. It swims like a snake. It may be found in shallow water, perhaps lying upon the bottom like a snarl of black thread, or smoothly 
coiled like the hair-spring of a watch, or twisted around a stem of water-grass. Where horses are in the habit of drinking, genuine hairs and the hairworms are sure to be found in close proximity, and this no doubt satisfactorily accounts for the hairsnake story.

Among the fish, the largest and most difficult to capture was the great king of the pike family, the muskallonge. Just how large these noble fellows ran was an open question. About forty-five pounds might have been the limit for trolling with the handline and spoon. Much heavier specimens occasionally were speared or shot. Most of the larger fish were secured by spearing through the ice. The heaviest of these might weigh from sixty to seventyfive pounds.

During late May and early June the muskallonge made their way up the larger streams to spawn, two fish, male and female, usually travelling together. The old Leatherstockings and the boys knew all about this; and while ordinary tackle was not to be depended upon, there were spears and firearms for such work. From gray dawn till an hour or two after sunrise was the best time, as then the fish were apt to be swimming near shore, or playing over the bars. Usually the first intimation of a fish's approach was a strongly defined wake stretching far upon the placid surface as the huge fish moved a few inches below. Then the important thing was to get to a commanding point well ahead of the apex of that spear-shaped wake. To accomplish this without scaring the fish was none too easy, as it frequently demanded some lively skirmish- 
ing through brush and up and down wooded banks. Sometimes gunner or spearman would chase the watery sign, losing and finding it again and again for a couple of miles, and then fail to get a good chance at the fish.

Not a few of the old hands at this work had favorite points where they would perch themselves like overgrown kingfishers and wait for fish to pass. This method demanded much patience, and it had a disadvantage in the fact that fish might be playing beyond the bends above and below and the watcher not know it. As a rule, the odds were in favor of the man who cautiously stole along the bank and kept a keen eye upon the water ahead. During the best part of a morning, he could cover several miles of stream and, perhaps, have as many as three or four chances.

In practised hands the long-handled spear did excellent service, but woe was the portion of the duffer who attempted to use one. Badly scared fish and a much-astonished mortal were the almost certain results of clumsy work, and fish once scared seldom gave another chance that day. Many of the country lads used cheap rifles, which were all right where the opposite banks were sufficiently high to stop glancing balls, but still there remained the chance of a ball speeding somewhere upon a dangerous errand. A rifleball glancing from water, or an unnoticed trunk, or bough, is a peril to the end of its flight, because it may strike creature or object at an apparently impossible distance to one side of the original line of fire. Knowing this, the fisherman, as every man should be, was extremely careful. 
A reliable shot-gun is as deadly to the fish, not nearly so dangerous in other directions, and much handier for quick work.

The pickerel, little brother to the muskallonge, was not held in great esteem. These fish ran from a pound to about fifteen pounds in weight, were full of bones, and the flesh was rather insipid. When the streams overflowed their banks in the spring, the pickerel sometimes invaded the lesser tributaries and ditches in astonishing numbers. Then the short spears and the guns were busy day and night, and great was the fun. By the light of torches, lanterns, and bonfires many large pickerel met their fate. Later in the season, pickerel were taken by troll and handline, by whipping with rod and spoon, or other artificial lure, and by live bait, such as the "shiner" minnow, grass frogs, and others.

An excellent fish, termed by the boys "pickerel," in reality the wall-eyed pike, was greatly prized for the table, but could not be depended upon for a day's sport. There was a heavy run about spring freshet time, when tons of them fell victims to the seines. At that time, too, numbers were speared in the discolored eddies; but later, during the regular season for the rods, only one or two would be found among a day's catch of good fish. Specimens weighing five or six pounds were not uncommon, while the seines took much heavier ones.

Three peculiar fish were taken solely for the pleasure of playing them, for none of the boys ever would carry them home. Most abundant of these was the "sheepshead," - the fresh-water drum, — a goodlooking, silvery fish, in appearance like the more 
valuable lake shad. They ran large, ranging from one to ten pounds, took various baits, especially crayfish and worms, and fought fairly well upon light tackle. All their upper parts were of a pretty, silvery blue, which below shaded off to a dead white, like white kid. In the head of this fish, also in the head of at least one seafish, are two enamellike substances. These, in the drum, are roughly circular, flattish, and in large fish about the size of a nickel. These substances are by the boys termed "lucky stones," and the boy's first business after landing a "sheepshead" was to crush its skull with his heel, or something as convenient, and extract those two precious affairs. One or more of them lurked in every boy's pocket, for were they not equal to the famed rabbit's foot of the South? No boy cared to hook and lose a sheepshead, and none would think of casting away the useless dead body without first "gettin' his luckies." The "stones" were marked upon one side with a design which suggested a pollard willow with a badly bent trunk, the rough resemblance of this bent trunk to a letter $L$, presumably being the origin of the luck theory.

I have caught scores of these fish, yet never tasted one, and I have yet to meet a white man who has eaten sheepshead. It is believed that the fish is astonishingly tough and flavorless, requiring a power of chewing. This may or may not be true. It certainly is a fine-looking fish, and, quite possibly, the boyish prejudice, like many another, really had no sound foundation. Occasionally a negro would take home a large specimen, but the majority of the dusky Waltonians declared the fish "pizen fo' 
shuah." At certain points we used to kill from a half dozen to twenty sheepshead in a day, the fish freely taking worms and crayfish, being so eager for the latter that not seldom a bait intended for a choice bass got into the wrong pew.

The second of our odd fish was the garpike, as a rule very abundant. This also was declared "pizen," and none would taste of it. To the boys, the gars were "swordfish," and only good for battle. A big gar, with his round, tapering body, stilettolike jaws, sharp teeth, and wicked-looking eyes, was an unpromising customer, specially designed for biting. During warm weather the gars floated at the surface for hours, and their trim lines suggested speed, power, and something of relationship to marine torpedoes. The bony structure of their long, lean jaws usually baffled efforts at hooking them, and, if hooked, their teeth were apt to cut anything but gimp. I have, however, taken them with minnows; but, contrary to appearances, they afford but poor play. A specimen a yard long would be considered a large one in our water. While the adult gar is decidedly ugly, the young are very beautiful. The very small ones look like golden bodkins, while one the size of a lead pencil, with his bronzy tinting, snow-white belly, and gleaming gold eye, is very attractive. These smaller fish may be found floating among the bent water grasses, and so closely do they match their surroundings, that only sharp eyes can detect them before they dart for shelter. One flick of the tail, always slightly curved for instant action, causes the smooth, slim body to vanish. We used to take these fellows by stealthy work 
with a small landing net made of mosquito bar, the gars being interesting for aquariums.

The third of the freak fish was prized for his decided method of taking bait and his stubborn resistance when hooked. He never was eaten, everybody agreeing that he surely was "pizen." This fish, the bowfin (Amia calva), was termed "dogfish," and he was an ugly-looking fellow, with a greenish yellow body, a big, toothy mouth, and a most evil eye. He would bite a finger for nothing, so nervous boys cut him loose and sacrificed a hook, also their prestige. Other boys beat $A$. calva to death with sizable clubs, regained the hook, and added to their fame.

Early in the spring the short spears killed many mullet. These red-finned, olive-backed, foolishlooking fish were held in fair esteem for the table; that is, about three good ones might purchase exemption from a whaling. When the water was at the muddy stage, the red fins were about all one could distinguish as the fish rolled in the eddies. Then one had to be quick and accurate with the spear, also able to tell by the fin exactly where to strike. With the mullet came the pallid-looking suckers - bony, worthless affairs, deemed unfit to carry home. Certain people, in whom much of the Old Adam still lingered, placed these suckers at the roots of cabbage plants, but the offer of one to some typical lad, or an invitation to dine off it, usually meant a tossing aside of hats and - the inevitable!

After clouded waters had run clear and regained their normal level came the season of seasons. 
Then the bass were on the feed, and the sport they afforded unrivalled. There were plenty of bass large and small mouth, black fighters, weighing from one to six pounds; square-built rock-bass, sometimes over a pound in weight; shapely white bass, not much as fighters, even when a foot long, yet dainty for the pan; and, lastly, the calico or grass bass, a showy, small fellow, and a quick, jerky fighter, and his distant relative, the small boy's pride, the beautiful little sunfish, or "punkin-seed."

Upon many days a catch would include all of these and other fish, such as catfish, bullheads, etc., which invade the chosen haunts of the bass. The best places were about old piling, submerged trees, where trees hung over deep water, and near lilypads and mats of grass. Among the baits were crayfish, minnows, white grubs, frogs, grasshoppers, larvæ of bees and wasps, very young catfish, and worms. They were esteemed about in the order set down, and if any one of them did not promptly tempt a fish, some other was substituted. The boys knew where to obtain all in their season. The fishing never was confined to one spot, nor did the boys believe that silence was either golden or necessary; in fact, they noisily chaffed each other and chattered at will. Their rule was that one place was good only so long as bites were not too far apart, and when water within reach had been thoroughly tested, a move was in order.

A small-mouth black bass was the prize first tried for, say about a submerged tree. For him, minnow, crayfish, frog, or grub was deftly cast a few yards from and all about the supposed stronghold. If two 
or more of the baits failed, the conclusion was that the bass, if there, was not in a biting humor. Then a rock-bass was voted good enough, and the bait was sent down as close as possible to the submerged trunk and into all likely-looking holes. The rockbass, all honor to him, seldom failed to be there and ready for business. So one promising place after another would be tried, the sport ending perhaps miles from the starting-point.

The rock-bass, for his size, was a good fighter, and better when properly cooked. He, also called "red-eye" and "goggle-eye," frequently showed as black as one's boot, always blacker than the true black bass, which really is of an olive-green above and lighter below. The boys called the rock-bass the black bass, while large and small mouth black bass were termed "green bass." Now and then great catches of white bass were made. I once took, where a creek discolored by rain joined the river's clear flood, more than one hundred white bass within one and one-quarter hours. I fished standing in a shooting-skiff, dropping the fish behind me as fast as they could be removed from the artificial lure. The rod was short and stiff, and there was little or no playing. Many more fish might have been taken, but the skiff began to leak, and I got ashore with wet feet. Presumably the muddy water of the creek brought down so much food that all the fish in the neighborhood were attracted to the common spot. They took the bait before it was two yards below the surface, and just as it passed the line between muddy and clear water. Another good fish for sport, while fair for the 
pan, was the yellow perch. These handsome fellows frequently travelled in large schools, which meant lively work. They would range from half a pound to three times that weight, and the best bait was the worm, although other baits sometimes proved useful. On a good day, and these were none too frequent, the catch might range from twenty to three times that number.

A very beautiful prize was the sunfish, for which every boy has a warm corner in his heart. A large one would weigh about three-quarters of a pound, but specimens one-fourth that weight are much more frequently taken. They are greedy biters and game in their own way, but their mouths are too small for ordinary bass hooks and baits. A very small hook bearing a portion of worm will at once be taken if the sunfish be there, and he is there in almost every stretch of our old waters. He delights in sunny shallows, in pools among the grasses, and he also is addicted to lying beside roots and rubbish near shore. It is a common sight to see these fish poised with wavering fins above their spawn, where the sand and gravel are only a foot or so below the surface. When a boy marks sunfish so engaged, these fish are as good as caught. They will not forsake the spawn, and they will bite, in hunger or anger, at anything dropped too near their precious charge. This fish, with the shiner and young perch, shares the doubtful honor of being first victim of pin-hook wiles.

Among rarely taken species were the young whitefish and the herring. These were delicate mouthed but most palatable, yet they played minor 
parts in our sport. When they did take the hook, the bait was a worm.

Catfish and bullheads, however, always could be depended upon - thirty or more of them during an evening. What the boys called "channel-cats" were taken from midstream by long handlines which had a sinker at the end and two hooks bent to short lengths of line above the sinker. Worms were deadly bait, and shortly after sunset was the best time. The catfish were of all sizes, from fingerlings with more horns than body, up to great bewhiskered ruffians of twenty odd pounds. With the exception of the head, repulsive with huge mouth, small eyes, and long appendages, the smaller channel-cat is a handsome fish. The body is clean cut, the fins well proportioned, while the silvery, scaleless, slippery skin is not unattractive. Fish of about one pound weight were excellent eating, although many people would not touch them. A half dozen of them, entombed in jelly, which also contained vinegar, hard-boiled eggs, sprigs of parsley and icecold, was - but those days have passed away!

These fish had to be very carefully removed from the hook. The long horns, or feelers, were harmless, but in the fins near the gills were awful, serrated spikes which could inflict most painful wounds. If allowed, the slippery cat would swing his head vigorously, whereupon the captor's hand or wrist was sure to suffer. The small mud-cat, or "bullhead," also has these weapons with a complete knowledge of their use. Frequently wounds from them caused a severe inflammation, which was apt to extend to both the temper and talk of the victim. 
When fishing for cats after dark, the boys often started a big bonfire. A lot of fun is mingled with the ashes of those old fires. A row of handlines stretched to the outer darkness, and the boys sat more or less patiently, each holding his cord. A whispered "Got a bite" would stop all conversation, and then would come the quick strike and the unerring snatching as dirty hands flew through their task of recovering the line. If the resistance told of a heavy prize, muttered grunts and inarticulate exclamations added tenseness to the situation, till the big fish thrashed the surface within the fire's light. Then would go up such a yell of triumph that our folks in near-by houses would not know whether we merely had caught a good one, or had all tumbled into the river. If we eventually turned up, they were, or pretended to be, glad to see us. Sometimes a boy did fall in and win as many yells as a fish, though the yells lacked the ring of true enthusiasm. We were such water-dogs that nobody bothered much.

At intervals a boy got a bite which puzzled him, though those hands could feel and recognize any fish through forty yards of line. Upon these occasions the excitement was keen. The last heave surely would land either a mud-turtle or a mudpuppy. Both of these were awkward customers. The turtle can bite like fury, and fingers had no business near those cutting jaws. The shortest way was to cut free the hook and allow the turtle to keep it as a souvenir.

The mud-puppy was different. No power on earth could induce a boy to touch that slimy, writh- 
ing, slate-colored shape. The fate ever was the same. The cord was cut, and into the fire went the hapless puppy. This creature, by the way, is a most repulsive-looking water-lizard. His four stumpy legs, heavy body, apparent lack of eyes, and bunches of external gills were neither understood nor appreciated by his captors. He was "pizen," and no respect was due those who rightly claimed he was harmless. He would bite, or at least try to, for never, to my knowledge, was he allowed even half a chance to illustrate his capacity in that direction. His appearance was quite sufficient. Peace be to his ashes! for he suffered much.

A lamprey, too, could cause quite a commotion. This creature the boys never could understand, and they were more or less afraid of it. At rare intervals, one was seen attached by its sucker mouth to a bass. The lamprey, or "lamper-eel," may once have been considered a delicacy, but the boys would have none of it. It might have killed an uncertain king, but it would kill no positively certain boy if he saw it first. This eel was from a foot to a foot and a half long, and possessed a circular, sucking mouth, with a palate well supplied with small, sharp teeth. Behind the mouth, upon either side, were seven small openings, which greatly puzzled the boys.

I have more than once seen bass thrashing about with one of these suckers firmly attached, and the fish's actions either indicated pain or a deadly fear of its comrade. One bass which I shot, and from which I detached the lamprey, showed an ugly-looking raw spot where the sucker had been. I have seen many bass bearing similar marks. Once, when 
some of the boys were wading in a pond left by high water, a lamprey fastened upon a bare leg. That boy did more stunts in one minute for no reward than he would attempt now for five thousand dollars! The thing finally let go, and only a slight mark remained.

So much for the fishes of boyhood, and, incidentally, for the boys themselves. Of that happy party, some have since learned about the fishes of the Shadow River. The others are scattered far and wide, some glad with human hopes, some, alas! gray with human griefs. Some have seen the great salmon pools and trout waters of remotest wilds, and have learned the science of modern tools and perfected methods. Perchance their barefoot training has ofttimes stood them in good stead. It may be that the survivors would gladly cast aside their modern improvements for the privilege of once again assembling by the old bonfire; to see the lines leading into the darkness, the floating captives upon their separate tethers, the mud-puppy roasting upon his pyre, and some thoughtful spirit calmly carving his initials upon a hapless, hissing "turkle." Quien sabe? 


\section{CCIADTIER VIIII \\ SOME TIRUTIS \\ ABOUT TROUTING}

Iт is wonderful how the first moistly warm breath from the south affects an old trout fisher. Even in that infernal city Cañon - a cobbled trail between sheer cliffs of soulless brownstone, mortgaged and otherwise, and inhabited by a brand of cliff-dwellers whose favorite form of angling is the playing of suckers - the magic of the south wind can assert itself.

Through my open window streams God's glorious oxygen, and upon the floor is a huge square of gold, painted by that mighty brush which traces the ebon shadows of huge trunk and hair-like twig upon the failing drifts and glassy surface pools of the North. Perched upon the very sash is a cock-tailed, bullheaded, thoroughly British sparrow, and he eyes me with an impertinent intentness which might earn for him a small, cold bottle that lately held ink, were it not that I love all feathered things from ostriches to oars. The rascal knows it, too, and besides he is full of spring and absolutely irresponsible. I know what his heart craves of me. There are some foolish strips of paper bearing nothing more valuable than a mere writer's silly notes, and, possibly, a few shreds of yarn are dangling from the right cuff of the hardworked jacket. Such things make a noble mess, 
when conspicuously packed against some inaccessible masonry, and the naturalized citizen wants them with that keen craving for small things which seems to possess the majority of imported citizens.

The song of the beggar is as exasperating as his insolent small person. He seems to "Chir-uff-chirrchirr-chirr-up," but woven through it is an undertone which distinctly says, "Ow! come out o' that, you bloomin' beggar; chuck away that bally pen; stop meddlin' with the blawsted stationery; it's spring out 'ere."

Only the old-time teaching, that not a sparrow shall fall, keeps me from flicking at him with the trout-tackle. And, as if he were not sufficiently exasperating, there is the everlasting New York boy, proud of new rubber boots and a handy puddle. I'll bet two dollars on that boy: one that he wishes he was a centipede so he could demand a whole lot more boots, and the other that he has attended one of the sportsmen's shows. Do you see that motion with the bit of lath? That is his idea of fly-casting. In his mind that lath is nine feet long, tapered, pointed, reeled, and lovely like the things he saw at the show. To his ghost-wand is attached a silken dream-line, and that puddle is foam-flecked and thrilling with stream music. That one out-ofplumb cobble-stone is a big rock, and that bit of banana peel is a trout - a two-pounder, mind you ! - and that silent, earnest, wading boy is going to get him. When? Never mind when. Sometime - perhaps in the Adirondacks, Maine, Wisconsin, or Quebec - the dream will come true. How do I know all this? Because that boy is allowed to come 


\section{Some Trutbs about Trouting}

over and play with me two mornings each week, and I never yet played with a boy without poisoning his young mind to the limit. "Spare the rod and spoil the child " may be true; but there's an old rod which can be spared for him, so soon as he can be pried loose from his mother long enough for an easy trek nor'rard.

And why not? There is no whisper of any evil in the song of the stream, nor one germ of harm in its hurrying flood. The heavenly music of the bobolink's golden bell shaken hither and yon above perfumed meads is only rivalled by the mirthful chuckle or rippling laugh of the trout stream playing its ceaseless game from sun to shade of its magic way.

Boys and tomboys should be given opportunity and encouragement to fish, because scientific angling is one of the cleanest, most instructive, and most fascinating of all our out-door sports. It embodies the true poetry and refinement of sport and this without any approach to the over-delicate or unmanly. Keen devotee of the gun as I am, yet I would hesitate to rank shooting as a refined sport above angling. It is possible, by the strictest observance of the true sporting code, to so elevate shooting that it becomes no unworthy rival of angling; but, unfortunately, too few men ever attempt to make work with the gun the clean, wholesome, educational thing it ought to be. As a rule, there is far too much killing and far too little intelligent study.

But to the trouting. Your old hand knows that the first few days after the snow-water has run out are apt to be the best. He also knows that it is 
possible to get a bit of sport on Long Island; better sport and more of it in the Adirondacks and some parts of Pennsylvania and the best of all the Northern states in Maine. Beyond that are the many Canadian waters of New Brunswick, Quebec, and northern Ontario. These offer sport unsurpassed amidst the wildest of romantically wild surroundings, and there are leagues upon leagues of rare good waters.

The north shore of the St. Lawrence alone offers ample scope for a life-long study of the brook trout and its ways, and few indeed are the men who have thoroughly tested the cold, swift streams of even the one stretch of the north shore between Montreal and Quebec, to say nothing of that region extending from north of Quebec to and about Lake St. John. Then there is the north shore of Superior, with its storied Nepigon and its dozens of minor lakes and streams, the latter short and fairly tumbling down rock-bound steps to the huge ice-cold basin, which floats no dead to its sternly hewed strand.

Among the gleaming network of waters flung over the country from Maine to Labrador, from Atlantic tide-water to the snowy surf of the Great Inland Sea, from the wonderful new country of the upper Ottawa down to the longer-settled slopes of the lower, one can find trout fishing unsurpassed in the world and, perhaps, only rivalled by the cream of the sport of the cloud-swept tarns and glacierborn streams of the Rockies and neighboring ranges. Thousands of miles of trout waters in all, and many of them practically unfished. Well might the scientific angler devote his life to them. 
But, perhaps fortunately, we are not all scientific, hence a few hints to the raw enthusiast may prove useful. In the first place, let him dismiss the notion that all, or for that matter one-eighth, of our trout waters offer unlimited facilities for all sorts of longdistance casting, for they do not. For artistic fly-fishing one needs must have plenty of space behind as well as in front, for the back-cast is the real difficulty. Here and there, in forest lakes, are reefs and shallows where one may wade and find plenty of room, but as a rule some craft, or raft, is necessary to enable one to get away from the shore. On the stream one finds room for action by wading up or down. This owing to the fact that comparatively few streams can be properly fished from the banks. Hence, stream fishing means wading, which demands a proper equipment, unless the fisher be one of that foolish-fond brigade who believe that a reckless defiance of cold water denotes the proper spirit.

But the wise man knows that long-continued wading and getting wet are bad for the human machine - that what may be laughed at to-day may be heard from later on, when the rich sporting blood has cooled a bit. It is all very fine to depend upon that broken reed, the flask, or that much-abused and seldom-understood thing, one's constitution. Both fail at times. A distillery couldn't remedy some of the possible damages due to foolish exposure, while the Constitution of the United States would be no guarantee against rheumatism or other evils. That a few men have been wet time and again for hours at a stretch is no proof that you can stand the same ordeal, and the trouble is that you have to do 
the sum to prove it. If you moved into a house just vacated by a doctor and found a small vial containing some unknown mixture, would you swallow that mixture just to learn if it were deadly or harmless? And in this connection, be not too readily guided by the statements of that too-prevalent old reprobate who is forever yarning of the old-time fishing and the heroic manner in which he and his friend just ploughed through everything and got wet every day from heels to midriff. It's just possible that he may be a fluent liar, because rumor saith that anglers are not exempt.

Because wading is the best way to get trout, and downstream the best way to wade, I do both, but before starting I do several other things which are rather important. The first of these is to don allwool underwear and thick woollen socks, because they are the best-known safeguards against a chill or taking cold. Over the woollen wear should go a gray flannel shirt, or sweater, and any old pair of gray trousers. If the weather demands it, an old gray coat should be added, while for the head there is nothing so good as an old, soft, gray felt hat - an old "Fedora," or a "wide-awake," is the very thing. Either of these will properly shade the eyes - a needful thing on sunlit water - and at the same time furnish a convenient place for the supply of hooks. For the feet, especially during the early season, there is nothing better than the rubber waders, which come well up to the fork and fit snugly to the thigh. They may be turned down to below the knee, which greatly aids one to cool off upon a warm day. 
Here, then, is the fisher dressed in a workmanlike and thoroughly comfortable suit, which, because the tree-trunks beside the stream, and also the rocks, present a general grayish tone, admirably blends with the surroundings, and fairly melts into the shadows early and late in the day. The next best color is the "dead-grass" shade of the regulation shooting-suit, but for the stream the gray is unrivalled. And I firmly believe the matter of costume is of more importance than some anglers are willing to admit. Long ago I made a study of the subject of shooting-gear, and from geese and other wary gentry learned the true value of closely matching the costume with the natural surroundings. Later, the color scheme for trout was taken up, and certainly results have proved that close attention to these fine points is good medicine. It is quite true that men garbed any old way can and do kill trout in some waters; but that by no means applies to all waters, especially those that are low and crystal clear. There are fool trout and educated trout, and the man who craves the valedictorian trout, or, for that matter, the sweet-girl-graduate trout, will do well to observe the common-sense rule, which reads, Dress as inconspicuously as possible.

A man once asked me if I really believed in the importance of correct dressing, which implied that fish could, as he put it, "see out of the water," meaning that a fish in the water could see objects upon the bank. I wondered, for that man had killed perhaps hundreds of trout which had leaped inches above the stream when taking his flies. I have seen a small trout not only jump for, but hook 
itself, in its effort to seize a fly carelessly left hanging against the side of a mossy boulder and several inches above the water. The eye is not always reliable, but I gravely suspect mine has seen a big trout gather in a white moth flitting a foot or more above the stream. This would not only suggest an ability to see out of the water, but to see most amazingly well, for a moving mark the size of a miller demands deadly accuracy. Furthermore, the neatness and despatch displayed by a big trout in getting into deeper water the instant a man appears upon the bank, shadow or no shadow, is strongly suggestive of an ability to see.

The advantage of fishing downstream is twofold, i.e. the fly or bait comes to the fish with the stream, as the fish has learned to expect prey to come. Hence, to meet pleasant possibilities, he is lying with his nose to the current, which can be made to assist in getting the lure where desired. Also, the man on any ordinary stream should have the needful space behind, while retaining the power to cover every yard of water below. The sole disadvantage of fishing with the stream is that accidental disturbance of stones, etc., may be carried to fish directly below, while sometimes one's extended shadow may cause trouble. The wise man, of course, does not make a habit of suffering his shadow to shift over every pool, but the trouble with shadow of man and rod may be overcome by shifting from side to side of the water as occasion may demand.

In regard to lures, the truth is that only a small proportion of early fish are taken with the fly. It is true that a host of anglers glorify fly-fishing and 
condemn bait; but it is equally true that a number of those very anglers use both bait and artificial lures other than flies upon those numerous days when trout are not keen for the fly. I have not the slightest desire to belittle fly-fishing, nor have I any hesitancy over saying that I have used most of the obtainable baits. Unquestionably, when fly-fishing is good, it is preferable, but unfortunately it is not always good, or even fair; nay, more often than not it is utterly unreliable and not seldom impossible. At such times, instead of fretting and stewing over it, I go get bait, and, incidentally, trout.

It may be the proper caper to sneer at bait, but to use it on fine tackle may demand the fly-fisher's skill and something more. The expert bait-fisher must know what the trout are taking and why, also where that thing is to be obtained and how. He has more to do than to reach for his hat or book, and if he cannot procure the exact thing, he must know of one, two, or half-a-dozen possible substitutes, and just where and how they are to be obtained at short notice, which is apt to mean he must get them for himself. After the fish is once hooked, the same skill is required to play and land it, no matter if it rose to a hackle, a worm, a grub, a young mouse, a natural insect, or even that oft-used old reliable a small section of some soulful sow. Hence it is not all of fishing to cast flies, nor is it all of sound sense to go without fish when you want 'em, simply because the poetic way to take trout happens to be by means of a bunco bug, fashioned out of barbed wire and millinery, and bearing only a questionable resemblance to any honest insect. 
But when the water, surroundings, day, and fish are as they should be, then indeed is fly-fishing the artistic and fascinating thing of which enthusiasts have raved ever since the introduction of fine tackle and its necessary fine art. The trail of the trouter must penetrate the picturesque - nay! it is one long gallery hung with the scenic masterpieces of East and West. Forever before one winds, or spreads, the silver pathway of the brook - the flashing shield of the lonely lake. Forever in one's ears is liquid melody of cold, sweet water, always singing to woody aisles of shadow, or breaking in foamy music about the feet of stony sentinels whose everlasting duty is to guard the gem-like lakes of all the forested North.

But trout fishing is not always the delicate play of fairy tackle upon baby streams and bantam lakes. Where the purple battlements of Superior's shore repel the white-maned cavalry of the queen of freshwater seas, there is trout fishing unrivalled for scope and grandeur of accessories. Where a big bay curves in behind the outer cliffs and leaves the tumult of surfy assault to leap, break, and retreat from its hopeless task, I have stood of a summer evening and wondered. A full half-mile of calm, crystalclear water, cold as the sweat of a dying glacier, was ringed and dimpled everywhere by the play of rising trout. The first big drops of a summer shower might produce a similar effect. And, to avoid a possible misunderstanding, let me say that brook trout are meant, and not "lakers" or any other fish peculiar to large waters. In the bays, coves, and at intervals along the north shore, the brook trout finds con- 
genial haunts. The Height of Land is only a short distance inland, hence all the good streams of that side of Superior are short, as they mostly are outlets of small near-by lakes. Even the famous Nepigon River, which might be termed the continuation of the St. Lawrence beyond the Great Lakes, is only about thirty-one miles long from its hasty exit from its parent, Lake Nepigon, at Flat Rock, to its final plunge into Nepigon Bay, an indentation of the north shore of Lake Superior. The chief merit of these north-shore streams is that they practically are natural fishways connecting many small forest lakes with the fresh-water sea. 


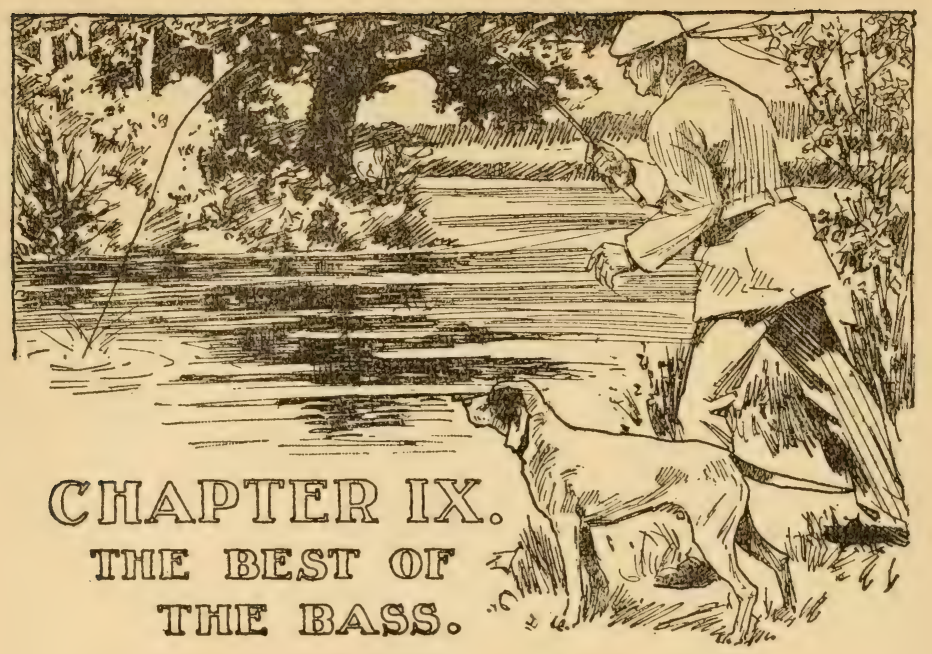

I GOT home about midnight - or somewhere in that latitude. Grounds and house alike were one black mystery; but where the gate was supposed to be, a dull white spot showed. I knew it would be there. Others of the family might pass in and out, they might leave early and return late, yet see nothing; but when I came home it was different. Just as sure as I neared that gate, no matter how long after midnight, just so sure was I to see that whitishlooking spot. Cold and damp made no difference - it would be there.

"Your wretched, neglected wife!" says my lady reader.

No'm, not the same. My wife hasn't got ribs like a spiral spring, nor four legs. I am referring to a D-o-g! D'ye s'pose I'd want my wife out there keepin'-tabs-and-gettin'-cold-feet and - but I digress. Not until I was within a step of him did the grand fellow move; then he slowly rose upon his hind feet and placed two dappled paws upon my breast, while 
his shapely muzzle sought my lowered face. For a moment my hand played with the silky softness of his thin ear, then as he regretfully slid down I asked, "Want to go, old fellow; want to go?"

Did he want to go! Such caperings, fool pranks, and fancy steps! Did he actually understand? Aye, right well. In his strange dog wisdom he knew that within four hours something would be doing, and just so sure as I went up for that much sleep, just so sure would he sleep on the door-mat instead of in his kennel, and be lying there quivering and shuddering, pointer-fashion, in an ecstasy of anticipation when I stole down 'twixt the dawn and the day.

How could he know? Don't ask me. I cannot explain, though I have my theories. Good dogs know much more than most people imagine. Educated dogs, that are made close comrades, especially those which have been owned, trained, and handled from puppyhood to their prime by only one man, get to know that man, his moods, and methods as few people know each other. This dog could read my face and interpret every shading of the voice. I could make his ears drop with one glance of mock severity, or set him bounding with a mirthful chuckle.

As usual, I was sitting up and rubbing my eyes before the clock gave its first warning skir-r! It's funny about that clock. If I didn't wind and set it, I'd oversleep till any old time; but after solemnly fixing the infernal machine, the appointed hour will find me staring at it, face to face, with exactly spare seconds enough for me to grab the thing, stuff it 
under the bedclothes, and sit on it to smother its tirade, lest others be needlessly disturbed.

It was a perfect morning. Through the wideopen window crept the rare breath of summer, a-tremble with bird music and rich with the sweetness of garden, orchard, and pine below. One glance at the flaming east told the story, then a plunge into cold water, a scramble into flannel shirt and knickers, a fumble with the other things, and I stole downstairs. I say stole down advisedly. This getting down was ticklish business. On my feet were lacrosse shoes - partly for comfort and silence, but chiefly for the sake of the canoe they would shortly be in. One door was hard to pass. One hundred times had I essayed to do it, and exactly one hundred times had I failed. But the rubber soles would fool her - I was almost past.

"That you, my son?"

"Yep."

"Going to dig that bed for me? - so good of you."

"Yep; goin'-to-dig-out-right-now."

"Did you say dig out or out-to-dig?"

Then I skipped.

Did I dig garden? Sure! I dug about four yards square, where the worms were good and plenty. Then I snatched a breakfast, gave the dog a bite, packed a snack - and fled from the wrath to come! Not until the good canoe had slid well around the first bend did the wicked cease from paddling. Then the pipe was set going, and Don and I straightened up and looked at each other. He knew - the villain! But she couldn't get either 
one of us till night - and she never could hold anything against a fellow for more than three minutes and a half.

For miles the land was level and the stream lazy. In such a country there could be no swift water, and this one dawdled along with almost no perceptible current. Yet it was no mere trickle of moisture, but a river full eighty yards broad and twenty feet deep. A few miles lower down its banks dwindled to nothingness, and the broadening waters drowsed through marshy wastes suggestive of Lincolnshire fens in olden days. But above my starting-point the land gradually rose higher and higher till it formed cliffs of rich clay, twenty feet and more high. The windings of the stream were so erratic that in one stretch of sixty miles by an air line the actual distance by water was one hundred and twenty odd miles. Nearly every mile of water was good fishing, but to a lazy canoer the upper reaches, being more wooded, were more attractive. Every one of the innumerable bends presented a picture of a steep, tree-covered bank upon the one hand and opposite a brushy flat of greater or less extent. This was caused by ages of the cutting away of the bank toward which the current happened to set, and a corresponding deposit of silt and rubbish by the slack water opposite. Such an apparent mystery on a lazy stream was naturally explained by the spring freshets. Then the water rose twelve, fifteen, or twenty feet and went raging lakeward, jamming miles of ice which uprooted hundreds of trees and ploughed like a glacier into every opposing bank. After the frost was out, the soft, undermined bank 
slipped here and there, and pitched grand trees, top first, into the stream. And where they fell they lay, perhaps for several seasons, until an unusually heavy flood tore them from their anchorages and flung them, battered and whitening, against some projection lower down, there to await the fiercer mood of an angrier torrent.

Such wrecks occurred at short intervals, and he who knew the river knew what to do at such points. With one tree already well-nigh submerged, and its fellow bending far over it and only awaiting a wind from the proper point to complete its fall, the bass found ideal quarters. The submerged tree was a fortress, from which dusky freebooters might raid at will. The overhanging trees cast a shadow of velvet darkness, fit screen for piratical deeds, and well! you know some grubs and larvæ are ridiculously fat and careless, and bound to slip from the smooth twig now and then. And young birds, too! It's simply awful the pace infants go these days. A young, naked thing, with its eyes barely open, actually trying to fly! and it comes down through the leaves with a spat-spat, its silly, pink-meaty abortions of wings spread and its wretched little bare legs kicking, and it lands - in the water? Occasionally. Sometimes it lands directly in a bass, and again the bass has to make a rush of a yard or so, to save the bird from drowning.

And then, again a few feet of the overhanging sod break away. Those mice are so silly! They will nest in the eave, as it were ; and then they must bore up so as to let down the surface water when the rain is busy. And then the whole affair tumbles in, and 
they wonder why. The sod makes a splash which no fish could help but hear. Then the earth melts away and leaves a big ball of dry grass, which floats and floats and rocks about till some kind-hearted bass takes a bunt at it, to find if it needs any assistance. And it loosens up, and a half dozen or more little pink things fall out, and go wavering, twisting, and shuddering toward the bottom. And kind Mr. Bass sees how it is, - he has babies of his own, - and he gathers in the small castaways, where neither the nasty wet river nor the horrid black mud will ever touch them again.

And then there are the frogs, grasshoppers, and crickets. Let a man, or even an old cow, but move along the bank above, and all these three must needs start a-jumping. Nobody's going to touch them, but they will jump, and they never look where they are going. Over the bank - then, of course, plop into ten feet or more of water. And the poor bass, trying to enjoy a little peace and quiet under his $\log$, has to hustle out and save life. Things even very foolish things - cannot be suffered to drown right at one's door. And the crayfish! Perfectly safe under the sunken stuff if they only would stop there. But no! out they go, backward at that! never looking where they are going - flip - flip flip - in a crazy rush; actually jostling decent, wellmannered bass; even striking them in the face, in their vulgar impetuosity. What can a poor bass do with folk like these? No rest for him! His life is one long struggle to teach his neighbors sense. But through all his toil and patient, uncomplaining effort, he at least has one satisfaction - his mis- 
sionary work is peculiarly effective. Never a one of them all — be it bird, beast, or bug - ever requires a second course of his potent pedagogy.

The man who knows his craft as he should thoroughly understands all these minor points. He knows what the large and small mouth black bass will take, and why, and when. He knows that the fish seldom, if ever, feed freely before the sun has got well above the trees, and that from about seven o'clock till eleven is the best of the morning. Why then the early start, do you say? Oh! well, it enables one to dodge all work about the place, to enjoy the best part of the day on the water, and to secure certain requisite baits. Some half mile from the starting-point the canoe halts, where a small stream flows into the river. Here is a tiny bay, already golden with sunlight, and a trifle up the stream is much water-logged rubbish. A can and minnowtackle are produced, and, while the old dog goes prowling after a possible woodcock, I take a dozen plump shiners. The next move is for crayfish. These are found under the sunken stuff, but the taking of them is an art known only to the experienced. Fragment after fragment of rotten wood is cautiously raised and every now and then " nipper" is exposed. The hand steals toward a victim, which is deftly secured. These lobsters of fresh water bite a bit, or nip, or whatever their pinching process may be termed, but they inflict no serious damage. Now and then one takes hold along the soft side of a finger, but rarely is the skin broken. A dozen are soon secured and then the trip proper is resumed.

I now have these baits, - worms, minnows, and 


\section{The Best of the Bass}

crayfish, and all are good at their proper time. Bass are very capricious feeders. Some days they will greedily take what they may have refused the previous day. A knowledge of this, and of what baits may prove tempting, is invaluable. One of the deadliest of baits is a big white grub found in rotten logs and sod. The larvæ of the bumble-bee and wasp, very young mice, grasshoppers, and small frogs are all tempting upon occasions. The fry of the catfish, too, is in some waters a reliable bait. Upon the stream in question I preferred crayfish, white grubs, minnows, and worms, in order as mentioned, and I always endeavored to have at least three of these. Now and then the fly tackle was called into play, but it was always unreliable.

The places where bass are sure to be include all types of submerged trees and snags, well-shaded spots under overhanging trees and banks, and mats of water-grasses and lily-pads. In the stream in question a fish is seldom taken from open water above a clean bottom. In swift streams having rocky bottoms the conditions would be entirely different, but I am speaking of one stream, not of bass fishing in general. The advantage of a thorough knowledge of the water is of the greatest importance. For instance, a mile upstream a big stump just shows above the surface. The current sets in there, and the spot is good for one fish, or two, if one doesn't make too much row over the first. Two bends above, on the opposite side, a big basswood hangs over - two or three fish there. A half mile farther, right in midstream and apparently open water, is a fine spot. Not a visible vestige of a 
snag or shelter of any sort, but twenty feet below an old tree lies on the bottom. Above that again is a small bed of weeds. At first glance it is no good, but there used to be a brickyard above, and the stumps of two piles broken off below water yet remain. About these is a lot of broken brick, all unseen, and it is a good place. And so it goes from point to point for fully ten miles. Almost invariably the fish lie on that side to which the current sets. The veteran knows this and changes from side to side of the stream as its course changes. A novice probably would select a pleasantly shaded, bay-like spot on the wrong side and fish there for hours, taking drum, catfish, dogfish, mullet, or sunfish, but at the most only an occasional, wandering bass. The black fellows lie in the current, with noses upstream, because they are strong pirates and they know the running water will bring prizes their way. When a bass is taken at some unlikely-looking spot, that spot should be kept in mind. There probably is some unsuspected shelter below which even the tackle may not find. In any event, a good lair for one bass is apt to prove equally good for another later on.

But to return to the canoe. A clay cliff throws a shadow upon deep water which might repay a trial. The cliff is bored with rows of black holes, and a cloud of sand-martins wheels on tireless wings. The soft muttering of dainty throats fills the air as the gentle little communists weave to and fro. The rod is shipped up and a plump shiner selected. The point of the hook is passed in at the mouth, out behind the gill-cover, and under a strap of skin behind the back fin. I use the bait so, because I 
have found it works well. Of course a bass swallows a minnow head first, but I don't want him to swallow it. That means a mangled bait and more or less trouble to recover the hook. The number of minnows is limited; therefore I want, if possible, to make one minnow kill two fish. When a bass grabs my minnow, I strike smartly and take chances. A fish so hooked forces the minnow up the gimp and out of the way, and so may preserve it for another turn. The third cast provokes a faint strike, not at all like the aggressive dash of the bass. A turn of the wrists makes a swift commotion of waters, followed by a peculiar steady strain. At the first purr of the reel the dog cocks his ears and eyes the wavering silk with keen interest. The rod goes steadily backward, and foot after foot of silk rises from the water. Then the gimp, and then a long, olive-green form, trim as a torpedo boat. Two long, snipy jaws, a lean bony head, a glowing eye, and - flick! The mangled minnow follows the slack line into the sunlight as the fish vanishes with a marvellous sweep. A gar, and where two or three of this kind are gathered together is no place for a decent fisherman with only a dozen minnows. The gar is a curious but utterly useless fellow, a loafer and a provoker of scaly language withal. Seldom will a hook hold in his bony jaw, and should it hold he affords but brief play. When recovering your hook his mouth feels like a barbed-wire fence, with a cat-brier hanging to it; so wise folk only shoot, spear, or heave rocks at him. The dog is disgusted - he knows all about gars and the talk which they incite. He also has a shrewd idea of what is coming. 
The paddle strokes are firmer and a purl of music whispers from the bow. We are nearing, hey! old $\mathrm{dog}$, and never have we rounded this bend without a thrill of genuine pleasure. Look at it and say can this be the North? The liquid floor narrows away like a mighty lance-head pointing to a glory of dazzling sunshine, and the soft-draped walls receding in perspective true, lower and soften to a golden haze of the distant open. Huge velvet shadows hang like windless banners; each tree seems rooted to a tree inverted, and over all is flung a living mesh of vine and creeper, bloom and bud and burnished leaf. It must be fairyland! From tents of green sound silver pipings and tinkles of tiny revels. A pause, and the flutter of foliage surely is the clapping of wee hands. It is fairyland! Yon sun-dried pebble by the water's rim takes flight and curves away on trembling pinions which shake sweet music from them as they go. A sandpiper? Nonsense!

Hark! - Tick-turr! tick-tick-turr! A fairy clock hid midst those leaves, its ruby pendulum swinging in plain view? Absurd! The clock has stopped, and yonder the pendulum, a dart of fire winged with ebon smoke. 'Twas the tanager swinging on a living cord. That rattle a snare drum? See where the quick ring broadens. 'Twas Alcyon striking the silver galleons of the dreamy sea of this our land of Spain. Can grief be here? A sobbing sweet and low, a hopeless misery floating from a tender breast too rudely torn; a mother peering through the dingy pane, racked by raw memories and the joys of others which she may not share. Oh! actor dove, we know thy sweet deceit. Thou sham of arms 
bereft; thou widow of one dry eye, with t'other roving for a comforter; thou male with female voice and gentle wile. Aye! Pat thy fat side with crafty wing and bow thy shapely head in mock humility - all's fair in love. But that same wing can whistle in arrow-flight, and strike full lustily should swearing trooper squirrel thrust his bold nose above the twig-wove platform where two white eggs lie. A rasping jar - a cymbal lightly clashed; a form of steel and bronze o'erlaid on jet, a heavy flight, a gleam of an eye like a diamond flashing from its kindred coal; a tail awry which seems to drag like an idle oar - the grackle. From an unseen meadow above floats a sound as though some sprite had stolen a string of gold and silver bells and was madly racing hither and thither from keen pursuit. But let us leave the bobolinks, and their neighbors the larks and sparrows, the orioles, thrushes, catbirds, warblers, finches, climbers, and what not. The air is vibrant with their voices, but we are not a-birding to-day. Here is the spot, it is the hour, and Don and I are the people.

A $\log$ -

Half sunk in the slimy wave,

Rots slowly away in its living grave,

And the green moss creeps o'er its dull decay

Hiding the mouldering dust away

Like the hand that plants o'er the tomb a flower

Or the ivy that mantles the fallen tower.

Don is all expectancy as the canoe is drawn up and the tackle adjusted. Next to actual shooting he loves fishing, and he sits with wrinkled forehead in such patience as he can muster. I decide to try 
minnow first, and while I am arranging the bait there comes a sudden splash as though from somewhere a brick had fallen. Out of the tail of one eye I see a shiner skip over the surface from the immediate vicinity of a heavy swirl. Good enough! It's minnow he's after, so the bait is right anyhow. In a moment my minnow is out far beyond the ripple and coming in with a wavering motion produced by slightly shaking the rod. But the cast is a blank. Another, too, fails, so I study for a moment. That fish is under the log, is the decision; so the minnow is cast perilously near the shelter. Another failure. At this moment I notice something. Looking from the dense shadow toward the sunlit outer water, I mark an unexpected snag some yards to one side. Mebbe he's there, I think, as the minnow again goes out. Still no result. Now comes the advantage of a variety of baits. A crayfish is impaled, and at once there's a sharp strike and the rod arches. A moment's feel of things proves that whatever is on the hook is no black bass. A brief struggle, and a square-built rock bass comes to the surface. Don is dancing with excitement, but a word sends him down. His time is not yet. The big-eyed captive is promptly killed, then the pipe is lit, the water meanwhile getting a few moments' rest - always a wise plan. As I hook a crayfish by passing the barb through the mouth and out through the tail (which gives the natural curve and insures the bait going downward tail first, as it should) the same bait serves twice, it having slipped up the gimp out of the way. But it fails. Another bait is wanted, so I climb the bank and find a half-rotten log. To 
heave this over is the work of a moment, and as the fragments fall apart three or four fat white grubs are revealed. I impale one of these and cast it to the edge of the shadowed water. Whether the bait is actually pitched into a bass's mouth is problematical. It certainly looks that way. A strike so savage as to make me fairly jump, and the fight is on. This is the best of the bass! With a rush he goes for his lair, and with a twitch I plant the steel and feel it take hold. A second's breathless pause, and then the royal fellow realizes what has happened. Whiz! and he is away like an arrow, while the silk hums through the guides, and the reel voices a startled shriek. Well I know there is no fray anywhere, so gradually the check is put on. Tense as wire stands the silken tether, while the rod arches till it seems as if something surely must give way. Five anxious seconds - then whish! up he comes fairly into the sunshine. A gleam of bronzy mail, a bristle of angry fins, a patter of falling drops, and plunk! - he has gone. But not far. Wise man never yanked at fish like this, so instinctively I have eased him down and away upon his second run. A fierce zigzagging, a worrying, backward pulling, a vain effort to bore to the log below, another dash, then up he comes again.

Have you seen him - the length and the breadth and the mad of him - and is this business, or is it not better than pawing coin or thumbing bills? The dog is a picture. He stands trembling with excitement, his blazing eyes following every movement. As the fish leaps he stiffens in every fibre; as it falls back his muscles slacken to the fear that 
the prize is lost. Heart and soul he is with his master in a game he cannot fathom, and he can barely contain himself. A leap and a grab might help, but he has not been called upon, so he suffers and whimpers and dances in an agony of uncertainty. But the headlong scrimmage slackens to an obstinate resistance. "You've asked for it, you beauty; now you'll get it," I mutter as I shake him up. One minute of doubt, and slowly, proudly, like the king he is, he yields, and a white ray flashes from his snowy belly.

A low cluck electrifies the dog - 'tis a well-understood signal. With a visible effort he restrains his impulse to rush, and steadily marches to the water and in up to his shoulders. Cautiously the fish is towed within his reach, and wise from a previous experience with fins, he grips it by the belly and carefully bears it ashore. Is he proud? Does he understand? Look at him! He has waited long for this, the crowning moment, and as the released victim flip-flaps in the grass, he dances an accompaniment of quadrupedal joy unmeasured. Then he shakes himself, takes a roll, and comes twisting and mincing, with deep, gusty breaths which say as plain as words, "We caught that bass!"

There were other battles and other triumphs five more in all - but let the one suffice. Great fish they were, too, as they tugged the cord which bound them in a shadowed nook. But only a half dozen? Aye! Why more? Two for friends, three for home, and room for one inside. A tiny fire mid the green, a lounge and a smoke on a scented couch, a search of a thicket for information 
of interest to man and dog; then hey, for the chase of the paling west into the evening land. Let the fragrant shadows creep, who cares? The bow is singing a foamy lullaby, the craft is skimming o'er liquid gold, the white puffs swiftly float astern; 'tis well, my lords.

But your feet are wet! - who cares? Your breeches are all green from grass and moss! What of it - it's what they're for - who cares? But you haven't done a stroke of work to-day! Who cares? But there's the garden patch not dug yet! Who cares? That big fantailed bass weighs plump five pounds - goldfish wouldn't buy forgiveness like that fellow! Do you understand? 


\section{CIIAPTIER X。 \\ A MATTTER \\ OIF IIASCALONGEI}

MuCh-NAMED, not infrequently much overrated, and not seldom much-abused, this fish occupies a rather ambiguous position among those species, which by virtue of certain fighting qualities have earned recognition as game-fish. Greatest of our pike, and a veritable freebooter of fresh water, he has his full share of that strength, speed, and voracity which have earned for his relatives the rather doubtful notoriety they enjoy. The term "wolf of fresh water" is not so far amiss as at first glance it might appear. Scientific authorities have decided that the mascalonge and its near relative, the great northern pickerel, shall be respectively known as Lucius masquinongy and Lucius lucius.

The 'lunge is found in the Great Lakes, their tributaries, the waters of the St. Lawrence basin, and the Wisconsin lakes. Wherever its habitat, it is the same old lusty pike, the savage of unsalted seas, and a holy terror to any other fish small enough to fit inside of it. Just how large the 'lunge grows probably is an open question - eighty odd pounds would be about the limit. I have seen one which scaled a trifle over fifty pounds.

The sportsmanlike methods of taking this fish are trolling with the rod and the long handline, and 
both frequently afford the liveliest of lively sport. Occasionally a medium-sized specimen surprises some angler who is using live minnow bait for bass, but such an event would be somewhat in the nature of an accident.

The variations of the name are rather curious, but they may be at least partially explained by the uncertainty whether the original name was Chippewa, French, or a mongrel blend of the two tongues. The Indians call it "maskinonje," the French "masque allonge," and these throughout the extensive range of the fish are varied into mascalonge, muscalonge, muskellunge, muskallonge, maskinonge, and masquinongy. For convenience, anglers use the abbreviation "'lunge."

The fish is subject to much variation in color, but this is a matter of locality and by no means to be depended upon should one be asked to decide if some big captive is a 'lunge or a specimen of the closely allied great northern pickerel. The membrane of the lower margin of the gill-cover is more reliable. In the 'lunge, it is furnished on either side with seventeen to nineteen bony rays to facilitate closing and opening the gills. These bony rays, termed branchiostegals, spread and furl the membranes at the fish's pleasure, somewhat as the ribs of an umbrella or the sticks of a fan perform their function. The great northern pickerel has from fourteen to sixteen of them, while the eastern pickerel ( $L$. reticulatus), and the western, or grass pickerel (L. vermiculatus), have twelve or thirteen.

An easier identification mark, however, is found on the cheeks and gill-cover. In the mascalonge 
the upper half of cheek and gill-cover is scaled, while the lower half of both is naked. The pike has a gill-cover scaled like the 'lunge's, but the entire cheek is scaled. The eastern and grass pickerel have cheek and gill-covers scaled all over. Hence if only the upper half of the fish's cheek is scaled, it is a 'lunge; if the entire cheek and half the gill-cover show scales, the specimen is a great northern pike. Young mascalonge are distinctly spotted with blackish on a greenish or grayish ground. The mature fish shows less distinct markings, although they usually are discernible in the region of the tail. I have, however, seen big, old fish upon which the eye could detect no spot, the general color being grayish green with a few dim reflections. Again, I have seen fine fish of a nondescript tint, as like that of an old, dry rubber boot as anything I can think of. The young and old of the great northern pike have the sides marked with oval whitish or yellowish spots, several shades lighter than the ground color - hence, a fish with spots darker than the ground color is a 'lunge; with lighter spots, a northern pike. I have dwelt upon these distinctive marks in the hope that what has been said may aid in clearing away a bit of the misunderstanding concerning these two fine fish. If the inexperienced angler will remember about the scales of the cheeks and gill covers and the color of the spots, he should make no error in his identification.

The 'lunge and his nearest kin are remorseless destroyers of other fish. Like so many old-time robbers of the Rhine, they have their strongholds from which to dash forth and raise havoc with the 


\section{A Matter of Mascalonge}

unfortunate wayfarer that may chance within view. The piscivorous habit is strongly suggested by a startling array of teeth, long and sharp, of various sizes, and so arranged that any fish fairly seized can see his finish without half looking.

There is something tigerish about the method of this grim destroyer. Is there a big nest of water weeds, or a handy clump of rushes, such as might readily conceal a few feet of huge rubber hose? Then swim wide of that spot, ye fat, lazy, fool fishes, for this particular brand of rubber hose is open only at one end, and that end carries a contrivance that grippeth like a bear trap with freshly filled teeth, and moreover, the trap seems to be always set.

The crafty 'lunge knows how well his long body blends with all water growths; that one sweep of his always ready, mighty caudal will send him speeding forth as though shot from a mortar, and that nothing upon which his wide jaws can make good their deadly grip is too big for him to tackle. Silent, motionless as a set spring, he waits in his ambush until a sizable victim drifts within range. The cruel eyes glow like wee incandescent lamps, but the careless prey sees them not, or if he does, mistakes them for two sparks of sunlight filtering through the tangled greenery. It is wondrous pleasant there in the velvet shade cast by the whispering rushes forever writing at the grand blue scroll above. From this same well-found shade, too, he can peer far out through the sunlit water and maybe make a small raid on yonder fairy fleet, where the silver galleons of the shiners drift on their lazy course. "I will tarry awhile," thinks the visitor fish. 
Indeed he will! Whish! Zip! The startled rushes sway and twist as the big, bent tail sweeps through its marvellous stroke; a swift hollow forms upon the oily surface, the sleepy, vertical shadows suddenly wake and dance in frenzy; there is a thrill of action for yards about, above; below, there is bloody murder! A tiny silvery bubble rises to the surface, bursts, and leaves an iridescent patch. That much slipped out between the gripping jaws. A few feet under, a dim greenish form drifts back from outer shades and lazily noses its way through the cover until it is again headed toward the open. Then silently, like the shadow marking the sun's decline, it rises among the yielding stems till at a certain point all motion ceases. The trap is reset!

Perhaps again and again will the drama be repeated, for the 'lunge is a gluttonous feeder. While it, of course, is impossible to figure out the destruction with any like accuracy, it must be no trifle. And the worst part of it is that the bulk of the victims are good-sized fish, old enough to reproduce their kind, hence of infinitely greater value than mere fry.

The unsportsmanlike methods of taking the 'lunge are shooting and spearing. The shooting usually is not so murderous as it might appear; in fact it is none too easy when the work is done with a rifle. A slowly moving or even a motionless fish is a very deceptive mark owing to the fact that it almost invariably appears to be about four inches above its actual position. The refractive power of water has caused many a good shot to miss what should have been an easy mark, and of course, the 
greater the distance and the sharper the angle, the more difficulty about driving lead into the water. In point of fact, a green hand will earn no glory shooting 'lunge, for, unless he can get almost directly above his fish, he will be very apt to blunder.

Nor will a keen and experienced man accomplish any serious destruction, for a single good fish would be a notable result of a day's skirmishing along the stream. Big 'lunge are only occasionally seen, and a glimpse of one is no guarantee of a sure chance to follow. The man with a rifle wants only big fish, and he may watch a stream all day and nearly every day for a month and not get one fair chance. When the 'lunge are running upstream the position of a heavy fish usually is betrayed by a steadily advancing furrow on the surface. With his eye upon this telltale, the man with the rifle skirmishes along the bank, keeping well concealed and always endeavoring to gain some commanding point from which he may look, and should circumstances warrant, shoot down.

Such points may be few and far apart, and the 'lunge may take a notion to swim deeper, or hug the farther side of the stream while passing, which demands that the man shall shift ground and endeavor to plan another ambush farther up. This sort of thing may be continued during an entire morning and no chance be offered; in fact, the odds are always in favor of the fish. A missed fish seldom gives a second chance. As it is quite possible to follow the wake of a fish for miles, to see the intended victim in the wrong place perhaps a dozen times, and eventually to lose him because 
you feared the risk of one or two doubtful chances, the shooting of the 'lunge is a feat seldom performed.

Spearing during the same season is well-nigh as uncertain. Some old hands at the game take very long-hafted spears and go sit at some handy spot from about dawn till as long as they can stand it. Others take chances with the short throwing spear, and, needless to say, seldom take much more than the chances.

The spearing through the ice inside a dark shanty is another method of the market fisher. He sits there smoking and playing the decoy and praying for "Night or Blucher," and Blucher may be afar off and hotly engaged in some unknown corner of what is doomed to be a sure enough Waterloo. Meantime the watcher peers steadily down into a mystery of green vagueness, through which extend ghostly growths like the wraiths of tropic forests. Flashes of silver light wink like aquatic fireflies and tell where burnished fry are playing, and possibly a yellow perch lances across the view and instructs the young idea that rod, pole, and perch are measures of deadly accuracy when used in finny schools. And after the fisher has grown to feel like the brown man of old, upon whose original invention his method is a glaring infringement, there comes a change.

The small fry disappear in some mysterious manner best known to themselves. There is a sort of glow in the water and from under the ice slowly slides a peculiar something. If the man with the spear be wise and ironed instead of nerved, he will 
play the decoy between his feet and coax the fish six inches farther. Right where his neck, if he had one, would be, is the spot, and one must not be afraid of hitting him too hard. I've heard - of course it's mere hearsay and perhaps untrue - there's a way of putting a bit too much strength to it, missing the fish, and following head-first after the spear. I cannot recommend this. There's a lack of ventilation and a prevalence of cold and damp down under there which are undesirable, if not positively dangerous. Getting wet up to his ankles may be a trifling matter to a robust man, but I suspect a good deal depends upon which end of him he measures from. A man may wet two of his soles with impunity, but the third never requires water unless but maybe that's getting too far ahead.

In trolling for 'lunge the old-fashioned handline and spoon-hook may be depended upon, but the method lacks the science which the use of a trolling rod demands. I have done a lot of it, and I prefer to go alone and do my own paddling, or rowing. A turn of the line around the thigh enables you to feel all attacks on the lure, while leaving both hands free for the paddle, or oars; and at the same time the line is where you can find it without loss of time. This is important, for the resistance of a heavy fish, aided by the forward motion of the craft, will tauten a line to the danger-point before you have time for many motions of your hand. While paddling, I make fast the paddle by a short cord, so it can safely be dropped at any point of the stroke. When once fast to a good fish I seldom bother about the paddle for turning, as there is a way of 
swinging a light craft head on to a taut line which is understood by all familiar with canoes and skiffs. An old pair of gloves is no bad protection, for a line sometimes cuts bare hands.

It is impossible to give anything like detailed instructions regarding the playing of a fish on a handline. A small fellow may be unceremoniously hauled in hand over hand; a big one must be humored. I believe in keeping at a fish all the time, taking no too pronounced liberties and allowing him none. So long as a firm, even hold be maintained on him, he is doomed, if the hooks are planted where they should be. Anything like jerking should not be allowed at either end of the string, for one stiff jerk may play havoc. Only over-excitement or rotten tackle is responsible for the loss of a well-hooked fish. On a handline a big fish might demand ten or fifteen minutes of play - I should say an allowance of about one-half minute per pound would be about his limit. I know many men tell of much longer struggles, but I never have seen them. The fact is a man fast to a big 'lunge is apt to be mighty poor indeed as a judge of time. It's like the answer of the benedict to the bachelor who asked if statistics showed that married men lived longer than single men - "Mebbe it only seems longer."

A good rod for "lunge is a high-grade split bamboo, or an ash and lancewood, nine feet long and weighing twelve ounces. This, with a multiplying reel of good make and about seventy-five yards of plaited "No. 3," or "E" silk line, and a No. O-3 Sproat, tied on gimp, will do the business. A large minnow, or a frog, makes a deadly bait, but 
many prefer a large trolling spoon having a single hook. Triple hooks for 'lunge are a nuisance. All baits for 'lunge should be moved slowly; a common fault of trollers with the handline is sending the boat along too rapidly. An excellent rule is to make as little noise and fuss as possible. From a boat pulled silently about twenty-five yards outside the weeds the bait can be cast to their very edge and slowly drawn away; I prefer, however, to troll along the edge, and by this method cover the most water with the least disturbance. Because a fish does not strike is no guarantee that it is not there, and for this reason I return to a good-looking place after a reasonable interval.

As soon as possible after the 'lunge bites is the time to strike, and the moment the fish is hooked the rower should make for open water. If this be delayed, there may be trouble, for the 'lunge is apt to play the deuce if he can get to cover. A good boatman will watch every move of the game and take full advantage of every chance to assist the angler. Too few men are reliable with the gaff. It should be cautiously passed under the fish - this cannot be done too slowly and carefully - and then sent home into the throat, with a smoothly swift, upward sweep. So soon as the fish has been boated it should be rapped on the head and a knife blade passed through the spine just back of the head. This most effectually will prevent any unexpected flopping about, for a fish so treated is dead - not merely stunned.

The best fish ever I killed was taken in Rondeau Harbor, on the Canadian side of Lake Erie. While 
from appearances the Eau should be an ideal water, comparatively few, but usually large fish are taken from it. Upon the day in question I had trolled with the handline around one end of the harbor, a distance of several miles. There was a broad border of marsh, and plenty of weeds in the water, but the great trouble was an overabundance of bass. These were fine fish, but I felt like Hiawatha, and craved the big fellow.

When I reached the entrance to the harbor, the lighthouse keeper hailed me, and after refusing some fish because he could catch more than he could use, he asked :-

"Why don't you try at the inner end of the piers for a big fellow ? Anybody could kill them things!" - the things referred to being some very fair bass. For a moment I fancied he was putting up a job, for the spot indicated was unpromising for 'lunge, but he was in earnest and I knew better than to dispute his knowledge. If you are going to do a thing at all, you may as well do it thoroughly - so I did. For an hour I paddled back and forth, taking a couple of good bass, but receiving no word from the desired big fellow. At last, when I had about decided to give it up, the keeper hailed me.

"You go too fast," he said. "Work clear down past that big clump of rushes, turn it, and come back here and see what you do. Go slow, now," he concluded.

It seemed a foolish task, but I went as directed, slipped round the rushes and headed back. Somebody must have applied for a stay of proceedings, for on a sudden everything was brought up standing. 
"Strange there should be a snag out here," was the first thought; for the line had tautened like a harpstring. But just then the snag got busy, and I grabbed the string and hung on to everything but a yell which broke away and ripped the sun-kissed silence plumb to the distant woods. Had I not known that horses didn't graze so deep, I might have imagined that I had hooked up somebody's three-minute stepper.

There was no mistaking the nature of the captive, for the way he fought for the weeds betrayed him, while nothing in that water save a sturgeon or a 'lunge could pull as he did. Headed off in his rush for cover he presently steamed for open water, and the way the canoe followed was a caution to behold. For minute after minute he pulled and I hung on, getting a foot or so of line now and then. Eventually he appeared to abandon all hope of getting to the weeds, and made for the end of the piers. I knew there were stones and snags in that vicinity, and so handled him as roughly as I dared, but he had almost entered the danger zone before he gave any sign of weakening. Finally his efforts became erratic, then feeble, and he drew, log-like, close alongside, though still refusing to keel over and expose that white badge of surrender which I was mighty keen to spy.

"Gaff him, man! Quick!" shouted the keeper; but I had no gaff.

The 'lunge was so big he almost scared me. His bristling teeth were too horrible to contemplate in connection with fingers through his gills, and for a moment I hesitated. Then, grasping the paddle, I 
lifted steadily with one hand, while the paddle went slowly over my shoulder. It was risky, but it had to be.

“Don't! Don't! You-condemned-fool-you'lllose-!" howled the keeper, but his protest was unheeded.

In all probability the strain I was under somehow got into my arm, for the only fish that possibly could endure such a clip must surely be a fossil and one of the toughest propositions in its line. As it was, the thin-edged paddle bit clear through the spine several inches back of the head instead of where I aimed, but I cared little about that. It wasn't my spine, but it was my paddle and my fish, and when a man can't paddle his own fish the way he has a mind to, things have got out of stroke.

The light keeper didn't like it. He said that nobody but several sorts of blank fools ever landed fish that way. When I assured him I'd have landed harder if I could have got more of a swing, it didn't improve matters.

"Why didn't you grab his gills? Them there teeth look sassy, but they can't actooally hurt nothin'!" he continued as he poked his fingers into the big mouth which I was holding open for a better view.

I always claimed the fish slipped in my hands, but he swore - quite a lot too - that I clapped the jaws shut. 


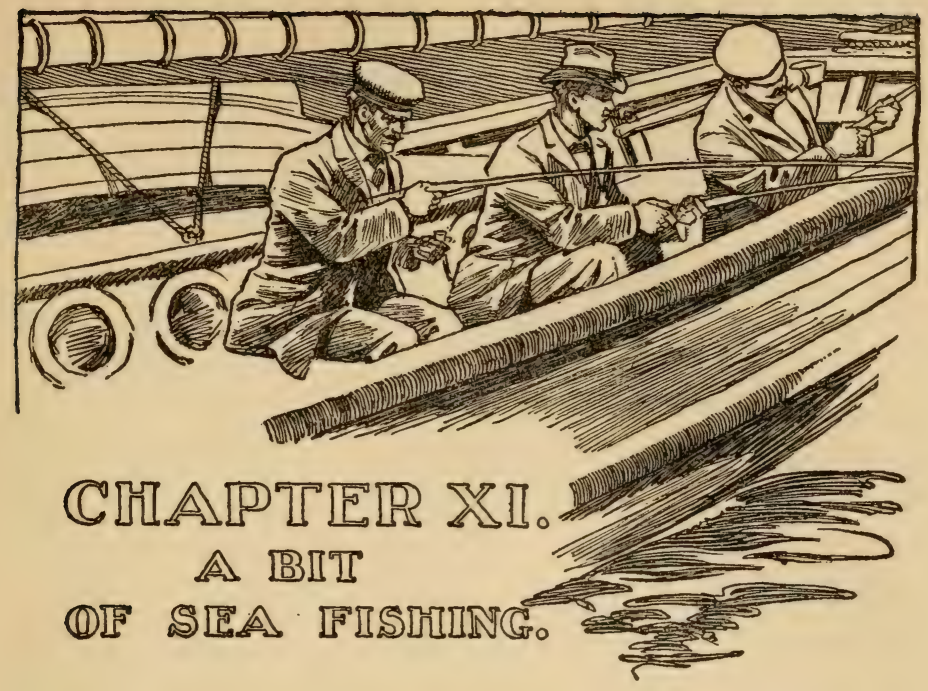

Hill planned the whole business. When he does a thing it is well done. He is a liberal, round, and merry soul, who revels in providing fun for others and a small share for himself. Incidentally, he is a very skilful angler, a man who has fished for many years, and who knows the ways of salmon, trout, 'lunge, and black-bass as well as he knows how to circumvent big sea-bass, "blues," weakfish, or anything else worth bothering about in the waters contiguous to Gotham.

None of his guests was let into the secret till the last moment, so I was rather astonished when he began to warble over the 'phone. The burden of his song was that a party should go down to the sea in a ship of his providing - in fact, be his guests throughout the venture.

When he had explained that Harry and "Cap" were to be of the party, I at once agreed to go, for right well I knew the ways of those choice spirits and the 
possibilities of a jolly day on the heaving breast of Old Atlantic. He further explained that he would start early in the afternoon to make sure that everything was all right, while we could take an evening train at our leisure. He would meet us at Hammil's Station, on the big trestle, and there was no need to bother about tackle, as everything would be ready.

It had been an extraordinary season, and the second day of October appeared like an estray from August. When we reached our destination, we presently found a very fair hotel of its kind and an excellent dinner of any kind. After that came a chat over the cigars, which Harry endeavored to cut short.

"Wasting valuable time-be invaluable first thing you know!"

"Read him the riot act," chuckled Hill, and I did, part of the argument being the magnificent night, good cigars, and pleasant company. Moreover, each man's money was still in his pocket, while sleep was a grand thing for men who had to arise before the sun.

"My money ain't still in my pocket," growled the incorrigible, nor was it, for we could distinctly hear the jingle as he turned it over. The sound suggested quarters, dimes, and nickels galore - the rascal had prepared for any emergency!

Now, I'm no immortal George, so the reader may grub up the root of the cherry tree, or not, as he prefers. Within an hour each man was in his room. Mine had two big windows, through which the lazy breath of the ocean passed at will. As I lay enjoy- 
ing air which well might have come straight down from the blue purity above, I could not help contrasting it with the smoke-laden stuff we might have been inhaling had we played poker.

"Bad for health to play cards," I drowsily muttered, for the air was doing its work. At that moment a footfall sounded in the hall, and soon a fist smote my door with no uncertain touch. I knew it was Harry still trying to get up a game, so I yelled at him - "Get away out of that-ye evil 'gam' - I won't play!"

"Yez wun't what?" asked a strange voice. "Git yez up, sorr, un yez'll not fish nayther. The hull av thim's up!"

"Why! What time is it?" I asked in amazement. "Faith, an' it's just wint foor! Lord love yez, d'ye tink I'm foolin' wid yez? Shure Mr. Hill towld me to haul yez out uv dat!"

I realized the situation and bestirred myself.

It truly was a marvellous morning. Not a breath of air was stirring as we went down the long wharf with its double row of club-houses. The whole world of waters was sleeping like a healthy child, and in the solemn dome of blue which roofed our field of action was not one vestige of cloud. The tide was busy, but even the great pulse of Atlantic seemed to beat weakly. The whole scene was drowsy.

It was beautiful, too. Across the channel spread broad marshes, swart from sun-baking, wholesome with salt. Above them hung a few bannerets of pearly mist casting peculiar, sharply defined shadows. Upon one side the barnacled, weed-tufted piles rose 
like long columns of jet studded with pearls and precious things, while their broken reflections in the creeping tide displayed a wealth of velvet shadow and silver sheen which only the brush of a master of black-and-white could portray. The wharf and club-houses of many colors seemed like the narrow street of some quaint old city, and when a picturesque sailorman approached, I half expected to hear him speak in some unknown language. But he did not. Instead, he fluently cursed the prospect of no sport and the weather which prevented the hiring of his sailboat to some fishing party.

Hill cared not for the weather. His roomy craft was quite a curio in her own way. Her owner, with an eye to calm, or an unfavorable breeze, had equipped her with a gas engine which, when white wings had to be furled, could drive her at fair speed.

"Can't fool me," he remarked, as he pointed out the engine, wheel, and tanks - "I fish for fun, and I want to be able to go and come when I please." He certainly had solved the problem.

Soon lines were cast off, the engine chug-chugged merrily, and the craft slid seaward in spite of the tide. We lounged at ease in sweaters and knickers, and prepared to enjoy our unusual experience. The engine, unfortunately, could not drive so large a hull fast enough for trolling for "blues," which demands lively progress. But there were other fish in the sea, and while a bout with the blues would have been preferable, the lack of it was not to mar our pleasure.

Once outside, the sea presented an extraordinary appearance, the like of which I never had beheld. 


\section{A Bit of Sea Fisbing}

The water looked like oil. Far as eye could rove there was not a semblance of a wave. Had it not been for the long, slow swing like the wraith of wave action common to that coast, we might as well have been upon the oft-quoted mill-pond.

For some time we steadily forged ahead under the pilotage of one hairy sea-dog who constituted the crew. Our chosen spot was over an ancient wreck, all that is left of an Italian brig which found her grave one awful night when walls of crashing white sent her straining hull to swift destruction. The old salts tell of grewsome things of that night - of piercing calls in foreign tongue, of bubbling prayers, and of battered forms wallowing in fierce undertow and flung high upon heartless sands as the breakers wearied of their sport. No doubt those tales are true; certain it is that the wreck now affords fine fishing.

Our craft anchored in proper position, and we prepared for business. Hill shipped up a fine bamboo rod, while the rest of us were given handlines which carried heavy sinkers, and two hooks each. The bait consisted of clams.

Of course the capture of the first fish was an interesting matter. I felt a gentle nibble, made a snatch, and felt I had something. Presently to the surface came a couple of dark, prettily mottled fish. As I hauled them aboard, Peaceman also landed one of the same sort, and so the honor of first catch was shared.

Harry looked at my captives and remarked: "And you wouldn't play draw! You bet if I could catch pairs like that I wouldn't miss a game." 
The fish were blackfish. They weighed about half a pound each, and I subsequently found that they were excellent for the table. They had small, sheeplike mouths with prominent teeth, which they presumably use for crushing small shellfish. An abundance of such food no doubt attracted the blackfish to the wreck. There must have been hundreds of them below us, for we had lively sport for a couple of hours.

An occasional tidy sea-bass afforded variety to the proceedings, and other things, neither so tidy nor so acceptable, took the hooks. Small crabs hung to the baits until they reached the surface, then usually let go their holds and sidled to the glooms. Now and then a piece of sharp work secured one of them.

The first big spider-crab, a hideous-looking varmint, was captured by Harry. At first it looked like a bundle of roots or a mess of the drowned Italians' spaghetti. Harry landed it between his feet, took one glance, then climbed the deck-house. When the spider got upon its feet and began to move about, Harry muttered, "Jerusalem! what hands he could hold and how he could manipulate pasteboards." Harry, however, would fish no more, vowing "that he didn't want to catch any more things like that in his draw."

Skates, too, came up at intervals. The first one captured was taken charge of by the crew, who promptly demanded a pocket-flask. He freed the skate from, the hook, turned it upon its back, then calmly poured a few drops of whiskey into the convulsively working mouth. In a few moments he 
tossed the skate overboard, whereupon the gyrations it described were simply amazing. "He's drunk as a fool," laughed the sailor, as he watched his unfortunate victim. The skate certainly acted as though it had taken a nip or two too much, but if its actions are what are referred to by the slang term "skate," as applied to the inebriated human, I desire no such experience in mine. It was good whiskey, too!

As time slipped away the fish ceased biting, but we were told the fun would be good again later on. Our kind host had provided a lunch, which came in most acceptably. After a long rest and a chat, "Cap" decided that the day was just right for swimming. He removed his sweater, and, clad only in his knickers, went to the side, presumably to test the water with his foot before plunging in. The crew eyed him curiously, then asked:

"Are you thinking of flopping over?"

Cap replied, "Sure I am - it looks fine."

"Maybe 'tain't quite so good as it looks," replied the man. "No fish has bit for an hour, and there's liable to be a shark 'bout as big as you are skirmishing around under there."

The expression which flashed over Cap's face was very, very funny, and the way he slid away was still funnier. The man told me that he intended no joke, and at the same time he jerked his thumb significantly in the direction of a couple of lily-irons which lay upon the deck-house. He further declared that he fancied he had seen a large, vague form drifting about below.

"Look there!" he exclaimed.

It may have been fancy, but it did seem to me 
that a big, shadowy thing for an instant was visible. At all events, the man meant what he said. It was a quiet joke on me, too, for I had been feeling fit for a swim, which, needless to say, I did not attempt.

All through the dreamy afternoon the heat held its own, and no breath of wind came. We fished until we wearied of apparently inexhaustible sport. We got as tanned as redskins, and at last some one looked westward and saw a tremendous crimson sphere sinking toward the water-line.

Simple as this form of sport may appear to those who know the best there is of river, lake, and brook fishing, the day had supplied a most enjoyable experience. The substitution of stiff rods might introduce more pleasing features, yet a congenial party, with a host like Hill, may find there is fun, even in the use of handlines. Not one moment of the time dragged, and, after all, it does men good now and then to forget their cares and just be boys together. 


\section{CIIATITIR XII. \\ RAII ANID \\ IRIEIDIDIDID。}

IN the sportsman's golden days, when every tidewater, marsh, and wet-land of our Atlantic coast attracted its host of the larger waterfowl, little if any attention was paid to the birds now under discussion. It is true that the rail was recognized as a delicacy, but more valuable game was so easily procured, and the sport it afforded was so much more attractive, that comparatively few of the old school of sportsmen were disposed to take the rail at all seriously. But it is different to-day. Three-fourths of the ducks and other highly prized species having been either destroyed, or driven to more remote resorts, the humbler quarry has its innings - possibly to its sincere regret. While neither rail nor reed bird can rival the waterfowl, grouse, cock, bobwhite, or snipe as objects of the sportsman's pursuit, yet they play no unimportant parts among our latter-day recreations. Ears accustomed to the clatter of the city's busiest quarter are open to the word from the marshes which tells of the movements of the small birds and of the tides which bring the cream of the shooting.

The sport, humble though it be, has certain attributes which entitle it to respect. It comes at a very pleasant season, when the demands of business are 
least exacting and when overtaxed toilers of the cities are best out of doors. There is no strenuous labor attached to it, so that too well-fed mortals, who have lost something of the energy and enthusiasm of youth, may participate without fear of consequences; and it is sufficiently reliable to insure its followers at least a fair measure of success. These are important features, which unfortunately cannot always be depended upon when one seeks other game.

The rail and the reed bird, though occupying the same haunts during a portion of the year, cannot claim even a remote kinship. The reed bird, Dolichonyx oryzivorus, is an icteroid singing bird, our well-known bobolink, also known as rice bird, skunk blackbird, and butter bird, in different parts of the country. During the spring the male of this species is a most conspicuous and charming figure in every pastoral landscape. His body-color of velvet black, boldly relieved by rich cream and white, would not fail to attract attention, even if his marvellous throat did not contain a witchery of song-producing power equalled by few American birds and surpassed by none. From the plumage is derived the name "skunk blackbird," the general black-and-white effect suggesting the coat of the handsome but unreliable quadruped.

The rollicking song of the bobolink is the cheeriest of bird music. The ripple of a merry maiden's laugh, the foamy mirth of a woodland cascade, blended with the tinkle of wee golden bells, might imitate it; the pen cannot. When heard at its best, the bird is drifting on lazy, ebon wings above soft 
waves of sunlit grasses. Then, while moving his pinions only fast enough to keep him in air, he gurgles out his liquid notes in an apparent ecstasy of happiness which it does one good to observe.

When in the humor, the bobolink is a swift flier, and this is best exemplified when two or more amorous males dash away in pursuit of the modestlooking, brownish yellow female. She may or may not put forth her best speed, but certain it is that she leads her gay-clad gallants through the maddest of mazy frolics. A foot above the grass she darts like a feathered bullet, now shooting upward for a few yards, now stooping low till her soft breast brushes the tender growth; again, twisting and dodging with amazing facility, to perhaps end a two-hundred-yard chase by a crafty swerve into the grass. Side by side, singing with all their might till their blended voices ring like a peal of merriest laughter, fly the pursuing males. Rising as she rises, stooping when she stoops, following every lightning twist and turn as though it had all been carefully rehearsed, they chase her like a small tornado of song till she gains her shelter. Then they curve away on trembling wings, jingling defiance at each other, - a defiance which surely contains more of mirth than anger, for its fiercest tone is soft and soothing as the gurgle of long-stored wine.

Few people would recognize this handsome minstrel of the meadow in the brownish yellow reed bird of midsummer and early autumn, whose sole note is a dull, monotonous "Pink-pink!" as the flocks veer and tack from point to point of the rice marshes. 
The truth is the male bobolink, like the mallard drake and several other species, doffs his gay lover's garb soon after the completion of the courtship. A respectable head of a family has no business to be knocking about in swell attire, and serenading and chasing females, no matter how modestly dressed they may be. So the bobolink bottles up his song, puts on his working clothes, and hustles in the commissariat department to satisfy the half-dozen gaping mouths in the grass-screened nest. When the young have grown strong upon the wing, the birds of several meadows assemble in flocks and attack the ripening oats. Thence they betake themselves to the marshes, to pose as reed birds after they have fattened upon the nutritious seeds of the wild rice.

The sport of shooting reed birds, or "reedies," as they frequently are termed, is too tame for the amusement of any one but a novice. As an adjunct to rail shooting it may serve to fill up time, but as the birds flock closely when moving and require no particular craft on the part of the shooter, neither skill nor excitement is ever prominent. Not seldom the flocks, owing to the nature of the ground, will follow one general line of flight; then all the shooter has to do is to place his boat, or take his stand behind some convenient growth and blaze away at the passing birds. A double shot may score as many as twenty "reedies." When well fattened upon rice the birds are delicious morsels, but no better than sparrows and several other small birds would be after a course of the same diet.

So far as this shooting is concerned, I do not for 


\section{Rail and Reed Bird}

one moment believe that the amount of profit or pleasure which a limited number of persons derives from the annual slaughter of thousands of birds is anything like a fair compensation for the resultant loss of the bobolink's spring music. Furthermore, the good accomplished by these birds in destroying insects during the nesting period will more than balance the debit item of oats as charged in the agriculturist's ledger. The inexorable demands of fashion have already played havoc among our most beautiful and useful song-birds, and we might well suffer the bobolink to safely pass through the reed-bird stage of his existence. If this were done, our fields might again ring with the melody of the olden days, and the Eastern states be much more pleasant fields for man's toil. So desirable a condition is not to be expected so long as guns roar the doom of the "reedies" nor while the riven lutes find ready sale. The man who can listen to the bobolink and still enjoy a course of "reedies," is about on a par with the consumer of English skylarks. And as for the pot-hunter who butchers the beauties for the pennies their wretched little bodies bring! - would he not glory over a pot-shot at an angel, the sale of the game, and the shrewd dicker with "Mine Uncle" for the golden harp?

The rail, or sora, Porzana carolina, is an entirely different type. It knows not music, its quaint, metallic chatter somewhat resembling the low, hurried cry of a startled guinea-fowl. It is a wader, a frequenter of the wet marsh and meadow and the border of the stream. Here it finds shelter, food, and a nesting-place. The rail's northward and 
southward migrations depend somewhat upon the weather, as it is rather delicate. It reaches our marshes in May, and the first sharp frost starts it southward. An intelligent examination of the rail will detect one of Nature's beautiful adaptations to certain conditions. The general yellowish brown, striped color-effect curiously blends with the stems of reeds, rice, and other water-loving growths. The deep, narrow body appears to have been specially designed to secure an easy passage through thickstanding cover, while the strong legs and long, widespreading toes combine swiftness with the ability to lightly trip over floating foliage which would not support a bird having feet of the average size. The flight of the rail apparently is such a feeble, fluttering, shortly sustained effort, that one is apt to puzzle over the question of how the bird possibly can traverse the great distances over which its migrations extend. It may be that the toilsome journey is judiciously divided into easy stages, but it is more probable that the birds select favorable weather, rise high, and are borne in their chosen direction by moderate winds. Well-authenticated instances of rails alighting upon ships far out at sea tend to substantiate this theory.

The color, form, and foot render the rail an extremely difficult bird to obtain a fair view of, or to cause to take wing in many of its haunts. Through thick growth it can glide like a field-mouse, while over the surface of a pond it can rapidly trot, though apparently treading upon nothing more stable than the surface of the water. It can swim and dive fairly well, and if driven to extremity, it 
may work its way under floating or stranded stuff and lie hidden with only its slender bill above water. The adult rail measures about eight and one-half inches in length, and from tip to tip of extended wings about fourteen inches. The upper parts are golden brown, with blackish markings in the centres of most of the feathers. A black stripe extends to the back of the head, the same color also encircling the base of the bill and broadening upon the throat. The sides of the head and neck and the breast are a pretty bluish slate, which pales to an almost pure white upon the lower under parts. The bill is greenish, shading into yellow on the lower maudible; lower tail coverts brownish white; flanks and inside of wings barred with white and sepia; legs yellowish green. Young birds lack the conspicuous black markings, their general coloration being browner, with a lighter mark on the throat.

The rail is locally known by various names, among which are sora, water-hen, chicken-bill, and that Jersey product, " rail bird." In addition to its running powers and apparent aversion to taking wing, it has one marked peculiarity which some of our best naturalists have observed and commented upon, yet have failed to satisfactorily explain. I refer to a sort of fit into which a bird appears to fall now and then. This fit, if it may be so termed, may be a paroxysm of terror; but be that as it may, it certainly is peculiar. It does not appear to have any connection with the report of the gun, but rather to result from some situation in which an uninjured rail imagines itself to be hopelessly cornered in the grass, or other cover. A bird attacked by the fit 
stiffens, topples over, and apparently expires. It may be taken up and examined for a considerable time without its betraying any signs of life. Place it among its dead fellows in the shooting-boat, and after a longer or shorter interval it may astonish its captor by either starting to run about, or by taking wing and fluttering away in the characteristic flight. Many sportsmen have noted this curious action and have naturally supposed that the stricken bird had been hit by a pellet of shot, and later had revived enough to take care of itself. This, however, is incorrect, as the bird really undergoes some peculiar attack, from which it will entirely recover if granted the opportunity. I have seen a rail crouched in meadow grass suddenly stiffen, when the only apparent cause was the sound of my boot rustling the herbage. Others have spoken of having attempted to pick up a skulking bird, which to their astonishment stretched out and seemingly expired as the hand was extended toward it.

I do not pretend to understand the matter, but it possibly may be explained in this way. In many of the rail's haunts are snakes quite large enough to swallow a full-grown bird. The rail's mouse-like habit of running through the grass may subject it to attack by these snakes. A rustling in the grass may suggest the presence of a big snake, as anything pointed at the rail may resemble, to timid eyes, the reptile about to strike. Those who dispute the snake's power to paralyze or "charm" its victim may scoff at this theory, but then those who dispute the snake's power are wrong in their own contention. The snake has the power and has exercised 
it before many pairs of excellent eyes, my own among them.

Owing to the rail's habit of skulking in dense cover, it can be depended upon for sport only in tide-waters. At high tide the marsh growths are so much submerged that a suitable boat may readily be pushed through their tops, while their protection as cover is for the time lost to the birds. At low tide a man might flounder about for hours without getting a shot, although rails were all around him. Because the birds are slow fliers, which usually rise at close range and cannot carry off shot, the lightest of guns and charges are best. The other requisites for the sport include the proper boat, a man who knows the marsh to act as "pusher," and a high tide. The pusher's business is to push or pole the boat through the best cover, to direct attention to rising birds, to mark down and secure what may happen to fall, to flatter and cajole a duffer, to gloat over a reliable performer, to swear audibly or under his breath as circumstances may appear to warrant, to assist at any spiritual séance at which spirits promise to freely respond, to get more birds than any other boat out for the tide, and to endeavor to get a line on the plumpness of his patron's pocket-book and to charge accordingly. A good man does all these things, not seldom including the patron.

The amount of shooting to be obtained largely depends upon the height of the tide and the skill of the pusher. But whether the gun be kept busy, or rests upon one's arm, the experience is bound to be a pleasant one. Properly propelled, the light- 
draught boat steadily glides through or over the yielding cover; a rail flutters up within a few yards and goes wobbling away, its feet hanging as though reluctant to leave the saving growths. The flush is indicated by the pusher's automatic cry of "Mark!" and the squib of the light charge punctuates a kill or a miss, usually the former if the sportsman is possessed of an ordinary amount of skill. The shooting may be continued till from twenty to one hundred shells have been exploded and the outgoing waters have uncovered so much lush growth that the rails can no longer be induced to rise. It is an easy, restful form of sport, with just enough of sunshine, of the salt strength of the marshes, and of mild excitement to do a business-worn man a deal of good. 


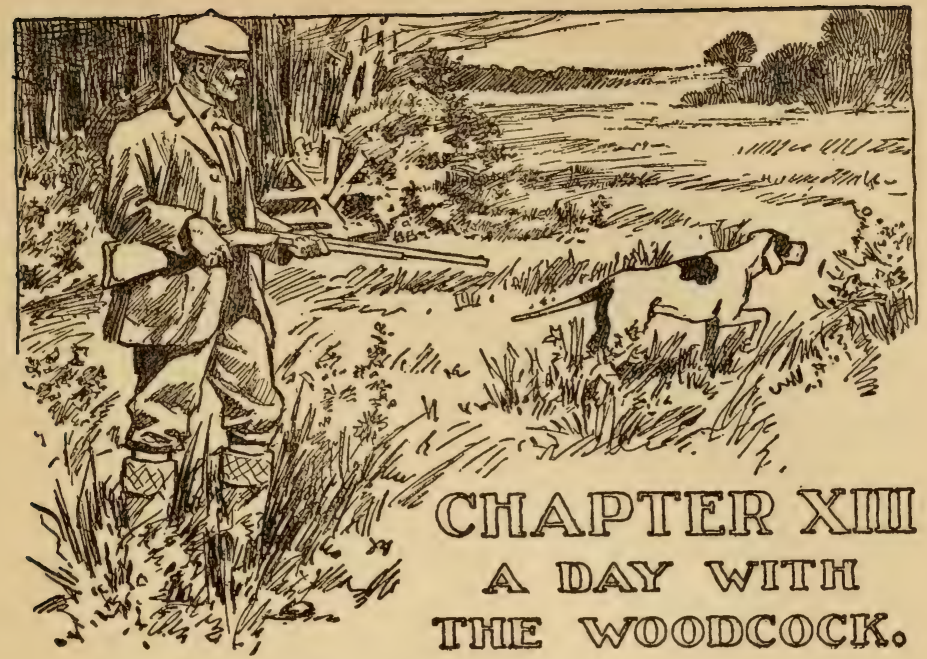

IN an extensive sporting experience one is certain to run across many very queer mortals, and perhaps eventually make friendships with one or more of those human oddities who come under the head of "characters." I have met many of them, and do not regret it, for, while they were very peculiar men, more than one proved well worth cultivating. The love of sport may lurk beneath a most unpromising garb, and we find some men, à la fabled toad, possess a brilliant redeeming feature beneath a most discouraging exterior, the true value of which must be learned through intimacy.

I have shot in many places and in varied company, and perhaps the strangest comrade I ever shared luck with was a big, bandy-legged negro, who bore the name of Duckett, or, as he was generally styled, "Ole Paw Duckett." Beyond saying that he was well versed in woodcraft, black as a barrel of tar, and the soul of good nature, I need not describe 
him further, but will give a day's sport with the cock in his company, and let the reader guess what manner of man Duckett was.

One fine Saturday in August the sable lady who presided over the culinary department of my house informed me that a "genlum " wished to see me at the door, and on going out I found my black friend and another negro awaiting me.

“Mawnin', Marse Ned; I 'lowed yo'd be hum dis mawnin'; kin I see yo' er minnit privut?"

We moved aside a few yards, and Duckett's errand was soon explained.

"Say, Marse Ned, I done diskivered a lot ob cocks in de creek, an' we'd best gather 'em in a-Monday. Dat Jones yondah spishuns sumpfin, but I'se done gwinter fool um. Kin yo' cum up in de canoe Sunday night an' bring de ole dawg? Der's a hull lot of 'em an' we best do de pawlizin' to 'em fust t'ing Monday mawnin'."

"But it's infernally hot."

“ Nebber yo' mind 'bout dat. It's jest gwinter up an' rain ter-morrow, an' it ull be cool nuff fo' a few hours a-Monday and mebbe fo' all day. Yo' cum 'long anyhow or I nebber tell yo' 'bout no mo'. We kin hab a nap on de hay in the barn same as we did dat time las' year. Now, yo' am comin' shuah nuff?"

"All right, you black seducer, I'll be there some time Sunday night."

Right well did Duckett know that the promise would be kept; and he departed with his friend Jones, the old rascal stuffing the latter with craftily worded explanations of his business with "Marse 


\section{A Day with the Woodcock}

Ned," for Jones was a market hunter in a small way and of course had to be treated cautiously.

Eight o'clock on Sunday night, after sundry manœuvres to escape scrutiny, saw man and pointer settling themselves in a Peterboro canoe for their five-mile paddle upon the currentless, waveless river. The dog deposited himself in the bow, with his keen nose resting on the 'wale and ever searching the air for trace of game as they moved noiselessly along. In the centre of the craft was a beautiful hammerless, the shells and a canvas shooting coat, while near the stern knelt the proprietor of the outfit, slowly plying his paddle.

It was a close, sultry night, with as yet no sign of rain, in spite of Duckett's prophecy of the previous day. But it felt like a shower, and as the paddler paused to relight his pipe, when half the journey was done, he took a glance at his watch and thought, " Nine o'clock - I'll be an hour late; but the old boy was correct about the rain, for unless my judgment is astray, it will arrive in the shape of a thunder storm ere this jaunt is done."

But the storm was distant yet, and he was in no hurry and moved but lazily until the moon climbed above the dark phalanx of silent trees and flooded the stream with silvery light. It was a familiar scene. Right well did he know every foot of that motionless water gleaming between vague, shadowy banks, and where the velvety shadows ended and the dim, uncertain shores began. Had it been darkest night he could have sent the canoe speeding along and never touched one of the many snags and sunken trees that marked the way. Ere long many fish 
rose, and now and then a heavy one leaped clear of the water and fell with a sounding splash.

From somewhere among the black walls of giant sycamores and walnuts a big-horned owl hailed the voyageurs in gruff, commanding tones - the allnight bass which more than owls acquire - "Whoo, who-you two?" with startling distinctness. The dog uttered a low growl and Marse Ned chuckled to himself, "You two" is good. Hailed by one chicken thief, while trying to keep an engagement with another. Then he sent back a masterly imitation.

"Whoo, hoo-hoo-hoo, whoo!" an imitation that fooled the midnight despoiler of hen roosts so completely that he challenged again and again. For a few moments the paddle poised in air while Marse Ned hesitated whether or not to run ashore and attempt to shoot the deep-voiced ruffian by moonlight.

"' 'Twould be a right charitable job," he muttered, " to fill you full of lead, you platter-faced scoundrel!" But he thought of the light charges in his shells and swung the paddle again. Every farmer and farmer's wife along the river were friends of his, and for a certainty the owl would have never lifted another fowl had there been any reasonable chance of bagging him.

Rounding a bend farther up, the dog shifted uneasily, and Marse Ned could feel the vibration from his nervous twitching through the light frame of the canoe.

"What is it, old fellow?" he whispered. The answer came like a flash. A sudden, tumultuous 


\section{A Day with the Woodcock}

splashing in the water, a rapid splattering of wings, then a succession of low, sweet, whistling cries, "O-eek-o-eek!" explained the dog's excitement. The canoe had glided across a small expanse of lilypads and had almost run down a flock of slumbering wood-duck.

It grew lighter and lighter, until he could discern small fry swimming close to the canoe. Presently he detected a slow-moving ripple gradually nearing, and exclaiming, "Lie down, Don!" he raised the paddle and struck a deadly blow at a dark, halfdefined shape passing. The victim proved to be a ten-pound catfish that had tempted fate while floundering along on business of its own. "That'll suit the old man," he muttered as he cast it into the canoe. Then the paddle was plied faster and the craft darted along in and out of the shadows like a winged thing. Soon the objective point was gained, and a voice from shore asked :

"Dat yo', Marse Ned? I know it is, fur I see de dawg."

"All right, old partner, we're both here," and in a moment the canoe was lifted out and overturned for the night. "Whar de debbil yo get dat big cat? My, he's a fat un - de old woman ull jist smile when she sees um."

"Killed him with the paddle back a bit. Now get your stuff ready and let them go to sleep inside. Here, take a nip, and give the old lady the catfish."

"Don't know 'bout dat; mebbe I best give her de cat fust an' den take de drink. Dat ar ole cullud lady cotch on to whiskey pow'ful smart - she jest liable ter want ter kiss me good-nite if she spishuned me!" 
And the old rascal bore away the fish, chuckling immensely at the bare idea.

When he returned they sat and smoked beside the river for an hour or more, while Duckett explained how he came to find the woodcock. Finally they sought the little log barn, and dog and all ere long were sleeping on the hay.

At daylight they bestirred themselves, and after stowing away some excellent bread and unlimited sweet milk were ready for the field. A walk of a mile and a half brought them to the creek, and a plan of action was speedily decided on. Where they were the creek, or practically dry watercourse, was perhaps thirty yards across, but farther up it broadened in places to five or six times that width, the enlargements being overgrown with tall willows, while upon either bank was a dense strip of thicket. In the spring this creek was a good-sized stream and a favorite resort for wood-duck, but during the dry season it dwindled to a succession of water-holes in a winding stretch of rich, black mud - in fact becoming what any sportsman would suspect to be prime cock ground.

Old Duckett carried a cheap "No. I 2 " breechloader, and as he shot in his shirt sleeves and wore an enormously broad straw hat, his tout ensemble was not calculated to encourage the idea that he was much of a sportsman. His cartridges were stuffed into his pockets and he carried no game bag, but the old boy had a knack of putting a couple of woodcock into the crown of his hat on a pinch, and could stow away a few more inside his capacious shirt front if needs be. After admiring the handsome little "six- 
teen" of his comrade, and making divers pointed queries in regard to its shooting qualities, he announced that he was ready for business. Only one side of the creek offered likely shelter for the birds, and the keen old man at once volunteered to take it, saying :-

"Yo' g'lang in de open and work de dawg between us far as dat ole tree [about three hundred yards], and I'll beat de brush. Den yo' take de brush an' me de open for de same distance, see?" The other saw, and also noticed that the arrangement would certainly give the other the privilege of being in "de open" at a very promising stretch, and he gravely suspected that the dusky worthy made the proposition with malicious intent; but he said nothing and they then started.

The dog worked close in advance, worming his way hither and thither through the rank grasses and ferns of the creek's bed and in and out of the cover upon the bank, until he suddenly halted where a few spear-like leaves of rushes marked a damper spot. He made a very pretty picture as he stood curved almost to a semicircle, his white back and lemon head sharply defined against the tangle of green, and his eyes staring intently at a clump of ferns almost touching him, while his jaws opened and closed with slow convulsive gasps, as though he would measure his panting breath lest it should disturb the hidden game.

As his owner approached there rose a shrill, quavering whistle thrice repeated, and three birds fluttered away with an uncertain bat-like flight, the trio springing close together, and, as frequently hap- 
pens, some few yards from the spot indicated by the dog. One vanished over the wall of saplings, but the others sped away side by side up the creek. The little "sixteen" spoke twice in rapid succession, one cock coming down in the open and the other just as the leaves were closing behind him in the brush. Any one hearing the reports might have fancied that the gun was not properly charged, for they sounded strangely weak and there was but a suggestion of smoke. Duckett evidently fancied that something was wrong, for his voice sounded from the brush.

"What de debbil's wrong wid dat baby gun? Am it sufferin' from a cold, or did yo' load yo' own shells?"

"Wood powder, you old duffer!" and the owner of the gun laughed aloud, for he guessed that the mysterious but valuable explosive was an unknown quantity to his sable friend.

"Did yo' kill um?" was the next query, and after being answered in the affirmative the darky could be heard crashing his way through the thicket. His over-keenness made him careless, and he flushed the third bird and drove it out directly in front of the weak-voiced gun, and it, too, was secured.

"Golly! dat's the funniest-soundin' stuff I ebber did hear. Whar yo' get dat, Marse Ned?"

"Now, see here, mister, you get right back into that brush! A bargain's a bargain and you're not near the tree yet."

"But I'se jest - "

"Never mind now! You just misfigured a trifle, that's all, and I stay in the open till the tree is reached." 
The old man's face was a study and there was a deal of craftiness in it as he suggested "dat dere didn't 'pear to be no sine in de brush, an' he 'lowed de birds must all be in de creek; " but the other was inexorable, declaring that the original scheme must be carried out to the letter.

"But de dawg's a-p'intin' agin."

"No, he's not; he's got a dead bird there."

"But yo' done got two in yo' han'!"

"Never you mind; I killed three."

"Yo' killed what? Now luka hyar, Marse Ned, I'se done comin' out ob de brush right now. Yo' can't fool de ole man no moah, gettin' him to tell yo' 'bout cocks an' den sendin' him to hunt whar he can't find none ob dem. I'se comin' right down dar, and de next one dat jumps I'se gwinter cut loose. Yo' heah me!" and down he came forthwith.

Moving on again, the dog soon located another and Duckett claimed the shot, and when the bird flushed he covered it and doubled it up dead as a stone just before it reached over. To say he was triumphant but faintly expressed his feelings; he rose to the sublime, and only returned to his normal condition when his proposal that he "orter hab de next two chances to even up" was firmly vetoed.

"What, you old reprobate! Do you think you can come that on me? Perhaps we'd better hunt every man for himself and the quickest get there!"

But Duckett knew better than that; he had tried it once before and had a wholesome dread of the snap shooting that would follow, for Marse Ned was "pow'ful sudden" when he chose to hurry. 
"No, we'se jist gwine to shoot right along, an' yo' ain't gwine to be hard on de ole man, seein' dat he tole yo' de birds was hyar?"

So they proceeded, and by the time they had reached the first enlargement of the creek they had seven between them, the darky bagging a couple and missing as many more. Before beating what looked a very likely bit, they turned aside to visit a little log-cabin at the door of which sat an ancient colored crone.

"Got any fresh water, Aunty?"

"Howdy, sah? Yas, I'll fotch sum. Good-day, Paw Duckett; yo'se a-huntin' again, eh? 'Spec's mebbe yo'se arter squrls?"

"No'm, me an' Marse Ned is a-huntin' woodcocks ; hab yo' seen any roun' dis mawnin'?"

"Woodcocks? Why, dey am num'rous; dey am a-rappin' on de tellygraff poles an' de fences all day long; didn't know dey was wuff a-huntin'," and the old lady picked herself up and went for the desired water, while Duckett surmised "dat de ole gal was pow'ful iggerant an' didn't know woodcocks from woodpeckers."

Returning again to the swale they found the cover very dense in places and agreed to separate in order to lessen the work for the dog, he being tired with his exertions in the tangled grass.

“Now mind, Marse Ned, no climbin' up on stumps an' overreachin' de ole man like I'se knowed yo' to do. Just work right froo all as it comes an' I'll do de same, an' we'll meet at de far end."

Birds were fairly numerous, and though quite a number were missed or got away without giving 


\section{A Day with the Woodcock}

a chance, still the "sixteen" was kept pretty busy, and every now and then the louder report of Duckett's piece told that he was getting sport. "Marse Ned," however, noticed that several reports came from about the same spot, and working over in that direction he found, as he had suspected, that the old rascal was in an opening and waiting for birds to be driven to him.

"Ho, ho! Duckett, no climbing up on stumps and fooling the old man, eh? You sinner, why don't you hunt through it?"

"Gimme time, Marse Ned, gimme time; yo'se bin a-drivin' 'em over hyar so fast dat I done had no chance to move 'long. De ole man ain't so spry as yo' be, shuah nuff."

"Spry be hanged! You're spry enough to know how to play tricks. Get into that brush and to work, or I'll fill you full of shot. Hustle now, or look out for yourself if I beat you to the other end."

Duckett, sorely against his will, moved ahead through the cover, and no sooner was he well started than Marse Ned mounted a huge stump and stood ready. Several birds flushed within easy range and from his commanding elevation he had no trouble in bowling them over, leaving the task of securing them to the dog, who performed his duties in a faultless manner. After a few shots an anxious voice exclaimed: "Say, Marse Ned, am yo' a-comin'? 'Pears to me like yo' am sorter hangin' back dar."

Just then there was a musical twitter of wings, and a big bird showed above the thicket and darted for the woods, passing some forty yards from the 
stump. The first shot missed, but the second doubled the woodcock up like a rag and sent it rolling down amid a cloud of feathers. Some distance off in a little gap in the foliage appeared a broad, black, and very anxious face, and the owner of it at once spotted the man on the stump.

"Hyar, Marse Ned! Too bad ob yo' to be playin' roots on me like dat. I knowed yo' was up to some debiltry. Yo' cum down offen dar; I ain't a-playin' dawg fo' yo'. But did yo' get um?"

"All right, I got him," and he descended from his perch and aided the dog to find the bird; and after it was secured the two worked on until the end was reached, getting a couple of cock on the way. At the extreme end of the swale was a small clump of willows, and they decided to finish with it, as it was now growing excessively warm and the pointer was dead beat; besides, Duckett's prophesied storm was apparently not far distant. The dog drew cautiously through the grass, but no sooner had he neared the willows than a cock flushed, then another, and another, evidently birds that had been driven there within a short time. One made back for the swale and Marse Ned stopped it, the others flew out in the open and now was Duckett's chance. Ere he could pull upon either Marse Ned's second barrel was fired, but the cock flew bravely on for a few yards, then came down in response to the darky's shot.

"Good on your head; you've wiped my eye!" But Duckett was squinting along the rib after cock number three, now a good sixty yards off. "Shoot, man, sh — " The trigger was at last pulled, and to 
Marse Ned's intense amazement the cock came down with a broken wing.

"Yah! yah! de ole man done got yo'. Fotch um, good dawg! How 'bout dat sneak powder an' snap shootin' now? He! he! doant yo' nebber talk 'bout shootin' no mo'. I'se done gwinter tell all ob dem 'bout dese doin's, heah me! Oh! Lordy, Lordy, it am better'n catchin' five coons to go an' do up Marse Ned like dis yar. My! I wouldn't hab miss' dat cock fur a hull farm. Marse Ned, yo' am flustercated, yo' ain't no good nohow. Yo' shute an' miss an' I bring dem down. Yo'se in de hole - pull de hole in arter yo' an' die!" and the delighted fellow laughed till he could hardly stand, in which he was heartily joined by his friend. Then they sat down in the shade to examine the bag.

Seventeen cock were arranged side by side, Duckett contributing seven birds, including a brace from his hat and a trio from inside his shirt. Marse Ned held a big hen in his hand, and pondered on what a grand one it might have been two months later. Right well he knew the difference between murdering cock in the warm season and stopping them when they are strong and swift and wild after the first frosts. He had shot many of them early and late, and experience had taught him that such sport as they had enjoyed that day was not cock shooting as it should be. There was a certain amount of fun in it, 'tis true, but it called for only moderate skill; and besides, there was the stouthearted pointer utterly used up in a few hours' time, and fit only to lie in the shade and gasp for air. Later on that same dog would see the sun rise and 
set and still be working merrily, and the cock would dart swift and free among the leafless maples, to be stopped but by a master hand. He had enjoyed himself fairly well, but he had seen something that saddened him. Through the very centre of the cover was a row of stakes driven into the soil that had fed cock for years.

"Is that the railway line, Duckett?"

"Yaas, de surveyors were froo hyar 'bout free mumfs back."

"Umph! Old boy, we got 'em to-day; but next season fellows will be jumping off the trains and hunting our grounds to death. There'll be a guidebook saying quail, cock, and grouse are plentiful in this vicinity, and twenty guns will be roaring in our choicest covers. But let's dig out, for yonder comes your storm."

A short distance away they met a negro with a gun. Quoth Duckett:-

"Dar you be, hey? But yo' done cum too late. Dat ar Jones is allus a-sneakin' on me. I tole yo' dat he spishuned sumpfin." 


\section{CIIAPTEIR ISIV. BILUIEISIII ANID BLUIE WATEIRS:}

There are those who take their pleasure climbing hills they never scale,

Or in snubbing short some bucking, sweating colt;

There are others who think Heaven's but a rope's length from the tail

Of a long-horned brindled steer in mad revolt.

Others clinch with mountain lions as sure antidote for care,

While others trail the moose and caribou,

And now and then one tackles half a ton of grizzly bear

And enjoys the maddest dance he ever knew.

Let them have their little pleasures with such hairy, scary toys For mine the whitecaps and the snorting breeze,

A heeling cat-boat handled by two husky sailor boys

And the troll-line straining through the choppy seas!

IN bluefishing, one of the hardest things to catch is the boat - that is, the proper boat. I have caught most every sort of boat, or rather quite a lot of them have caught me; but we must live and learn. The wrong boat is undesirable in many ways, chiefly because it is apt to contain the wrong skipper, and, if crew there be, the wrong crew. On the principle, I suppose, that two or more wrongs never made a right, the man who unfortunately engages the wrong outfit is mighty apt to find his pleasure seriously hampered by limits. It is therefore well to inspect the craft and size up her owner in advance if possible, for of those who go down to 
the sea in ships, especially cheesy-planked, painttinkered ships, quite a few are foggy in their conceptions of what constitutes a square deal - land measure. For, be it known, there are a few, mercifully only a few, skippers of crafts for hire, who appear to labor under the delusion that a man from New York is a sort of little brother to a distillery and naturally a man of proper spirit. While undoubtedly a good deal of the true spirit of sport has been transferred to paper and canvas, it has never been put up in glass, hence the wise man will keep that section of the stores solely for emergency.

But there are A. B. skippers and stanch craft, though but few of the rating of Captain H. and his beloved Osprey. Long, lean, and weather-checked as a stick from some old pirate, Cap might pose for a study of the Ancient Mariner himself. The Osprey, too, is an ancient. Only the boys of the Old Brigade can recall when she was the crack of her class - in fact, a racing single-sticker of more than ordinary merit. She has one modern improvement which must almost break her heart, but which is exceedingly useful during windless, midsummer days. It is a gasoline engine which Cap introduced for the purpose, as he invariably explains, of "kickin' her along home so's the city fellers kin be sure of ketchin' their train."

The Osprey has a crew, too, - a taciturn, weatherbeaten, bow-legged crew, - with a breast huge and hairy as a cow's paunch - and arms, ye gods! such arms! Silent, no-necked, barrel-like, when he wanted to go anywhere he never attempted to use his amazingly short, parenthetical legs. Instead, he 
merely reached with either hand, then the whole of him followed the hand with an easy swing startlingly suggestive of tropical tree-tops. Cap noticed my close watch upon the movements of that crew, and presently said: "He's a wonder. Never nothin' to say - jest slides round as easy as grease. But he comes by it honest. His dad was skipper of a merchantman in the African trade, an' his ma'am was as good a sailor as the old man. I've heard her tell of mighty queer places where she's been, full of niggers an' gorrills an' the like o' that."

"A-a-ah!" was my sole comment, for at the moment that crew was swinging for'ard, using his arms as a cripple uses crutches.

At this season, the bluefish (Pomatomus saltatrix) is given to prowling along the coast, probably as far north as the Canadian boundary. The range of the fish appears to mainly depend upon the temperature of the water as well as upon the movements of the great schools of lesser fish upon which the bluefish preys. According to scientists, it is found in the Mediterranean, near Australia, the Cape of Good Hope, and other remote points. It is known, by several names, such as "horse-mackerel," "blue snapper," and "skip-jack." In New York waters, the young bluefish are commonly termed "snappers"; and right well do they deserve the name. From mere babyhood to a, perhaps, twenty-pound "tide-runner," the bluefish is a remorseless destroyer of the menhaden, mullet, squid, and presumably of other fish of suitable size, which term, in bluefish estimation, is apt to mean anything which can be snapped in half, or bolted whole. 
Powerful, carnivorous, seemingly insatiable, a school of mature bluefish is worse than a pack of wolves so far as wanton destructiveness is concerned. The wolf will slaughter, gorge, and sleep till again hungry, but the fish seems to slay for the mere lust of slaughter. Close observers have claimed that a blue bravo will cram himself to the jaws with food, then eject it all and resume the slaughtering and stuffing and repeat again and again. While not disputing it, there may be an explanation of such outrageous voracity in the fact that the fierce grip of blue jaws is apt to cut a soft victim in two and the floating section to be mistaken for a part first swallowed, then ejected, by the destroyer.

Murderous and senseless as such an attack seems at first glance, it may be, most likely it is, one of Nature's wise provisions for the welfare of her feebler folk. The wasteful, snapping blues may leave their long trail littered with unsavory mess, may drive the terrified mossbunkers in crowds upon the deadly sand, but who follow? The keen-eyed gull and wheeling tern can read "sign" from afar. They know the veering ripple which marks the flight of the jammed mossbunkers and why silvery forms shoot above the surface, or strand upon the beach. They know the blue terror merely as a lovable, philanthropic gentleman, who, in the great goodness of his heart, fares forth for sport where they may see and kindly leaves them fair share of his quarry. In such cases, a lot may depend upon the point of view - possibly even upon the point of view of the miserable mossbunker. Yet who is a greasy moss- 
bunker, anyhow, that he should dare to question the right of my lords of the sea and the shore? And then there are the slow, stiff-jointed things forever crawling the sea-bottom. A heap of mossbunker must eventually fall their way, and it saddens the heart to think how they might never even get a smell of mossbunker - and the smell of some stages of mossbunker is something like a smell! - were it not for the charitable bluefish and his somewhat reckless method of distributing things.

The secret of Dame Nature's perfect success as landlady of the Hotel Earth lies in the fact that she never wastes anything. If there were the slightest of wasteful methods, eventually there would be a shortage, which there is not. There may be an apparent shortage, an actual scarcity of one or many forms of life, but that does not necessarily mean a real decrease in the amount of life in the world. A dead bluefish certainly means a gap in the ranks of the blue host, but by no means a similar gap in the marvellous plan of Nature. The bent-wing tern, the crab sidling drunkenwise, or one or more of a host of small creatures, may be that defunct bluefish done up in another style of package. Our Puritan progenitors were promiscuously planted upon certain headlands of our older East. That those same headlands are none too fertile to-day is, perhaps, but natural, for the sainted forebears, according to reports, were kind of lean and lacking in warmth and richness. Anyhow, be it meat, or meal, no truly scientific mind ever would tolerate the idea that Standish \& Co. ever really ceased to do business at the old stand. Unseen, unsuspected, they are to-day, as it 
were, in our midst, but - well, at all events there is no waste, which was the original contention.

The most common methods of taking the bluefish are trolling, or squidding, with long lines from a sailboat, and, from the beach, with a stout handline. Not a few keen anglers use a heavy rod with fair success, but this is not the typical method. The tackle needs must be strong, and, owing to the cutting power of the blues' jaws, hooks are attached to wire, or the stoutest of gimp. Even then it is not uncommon for the tackle to be cut, either by a hooked fish happening to get the cord between its jaws, or by the bait being forced up the line and inducing a second fish to snap at it. The usual baits for trolling are an eelskin, or a bit of rag, but a bluefish will strike almost anything of proper size that keeps briskly moving. For work with the rod, the most reliable baits are lobster-tail, shedder-crab, chopped mossbunker, or other bait-fish.

The fishing from the beach is the genuine heaveand-haul - the old-fashioned handline of boyhood days glorified. The heavy squid plays the part of sinker, and the way it will carry out a, perhaps, hundred-yard line from a skilled hand is a wonder to behold. And by that same token, the gay and reckless manner in which it can act up when manipulated by a novice is still more wonderful. Three important things govern the use of this tackle - i.e. the squid must go far enough to straighten, maybe, one hundred yards of cord; the line must run out freely and smoothly, and the hand-over-hand recovery must start so soon as the squid has touched the water, and be maintained at an even, rapid rate 
until there is a strike, or the squid has passed within the limit of good water. The prowling blues feed outside the surf, hence the squid should strike the water well beyond that point.

The amateur squidder frequently makes fast the home end of the line about his waist, or to some bit of wreckage, or other convenient hold, and neatly coils the line upon the sand. Experts term this "lubberly," and hold the coils in one hand, a thing which no novice should attempt. For the heave, a right-handed expert holds the line in that hand at a point his preferred distance above the squid, which is started slowly swinging around his head. When nicely going, the speed is increased till the whirling tackle fairly whistles; then, at precisely the right instant, the final heave is given. The squid hums seaward like an arrow, the line hisses after, and when everything is as it should be, the squid plunges into the water ahead of an almost straight line. Expert heaving is a beautiful thing to watch, but the ambitious novice will do well to practise a bit before posing in front of a seashore crowd. I once saw a blooming, blond Briton in a blatant bathing-suit hook himself about the only place where a big hook could enjoy a fair chance, whereupon the plaudits of a mixed audience rendered a swift retreat, a surgeon, a file, and a few other things - stern necessities.

A squidder should wear stout gloves, but many enthusiasts gamely tackle the job bare-handed and learn about the scarifying power of sharp sand and a straining cord. To pull a fighting blue through the surf is no easy task. Quite frequently the 
squidder, upon feeling a strike, swiftly turns about, slips the line over a shoulder, and runs up the beach till the fish is dragged ashore. For this vigorous sport, the best costume is an old bathing-suit, and, because my feet have suffered from bits of shell and other odds and ends, I believe in old yachting, tennis, or lacrosse shoes. This hint is given solely for the benefit of those who may desire to don fashionable foot-gear when the fishing is over.

And now the trolling, which is by far the most popular form of bluefishing and which each summer gladdens or disappoints thousands who turn for holiday pleasure to the Big Salt-Bath. Once aboard your cat-boat and well off-shore, the all-important thing is to locate fish. Let it be understood that the strong, moderately long trolling tackle is supplied with the boat, and we will return to the Osprey, which is lying in the channel awaiting her patrons.

Over the heaving blue a cloud of snowy terns was wheeling and dropping, and it was easy to guess what massacre of innocents had baited the graceful air-rovers.

"Look lively!" roared Cap, pointing at the water where flecks of white suspiciously like fragments of fish were speeding past. My line seemed to be quivering with anticipation, yet we slid on and on with nothing more startling than the continuous drag of the tackle.

"We've overrun 'em. Yonder they be-an 'bout we go!" warmed Cap, and the Osprey wheeled and went driving toward the guiding terns.

"You sea-jackals - you fiends upon angel-wings" 
- I muttered at the fowl - "would you betray - " but the thought snapped like an o'erstrained wire, for lo! what felt like the behemoth of old was jerking at my tackle. The Anthropoid fell forward upon his hands, his shoulders level with his ears, his eyebrows twitching up and down in joyous anticipation, while I snatched at the apparently hot cord and kept a big blue coming so fast that he only touched water at intervals. Over the side he came bleeding like a pig, and in a moment the hook was freed and overboard. The fish was not nearly so large as his pulling power had suggested, but there were more to follow. Leaving the captive to the tender paws of the Anthropoid, I braced for the second round, which was not long delayed. Another fish, and another and another, speedily followed. So far as I could see they were exactly alike in size, gameness, and strength. Within a couple of hours we had killed about a dozen fish; then the terns disappeared, and for some time the troll dragged vainly. Cap was idly humming to himself, when the Anthropoid grunted and pointed shoreward. I could see no terns nor anything except water, but the Osprey came about and Cap explained - " $\mathrm{He}$ seen somethin' jump - we'll jest try it."

How the Anthropoid had conveyed his knowledge concerning whatever had jumped, was a mystery to me. Certainly he had not spoken, but for all that it was his privilege to convey facts according to his lights. That he had seen something was presently proved by a tremendous jerk at the tackle. In an instant I had all I could attend to, for that fish fought like a salmon. Watchful Cap threw the 
Osprey into the wind, otherwise the tackle might have suffered. As it was, there followed quite a fight, which ended with the coming aboard of a grand blue, which felt like a ten-pounder and which, upon unprejudiced scales, actually did weigh a trifle over eight pounds. He gave me quite a start, too, by viciously snapping at my fingers. There was no mistake about it - the beggar tried to bite so I gave him a course in marline-spike seamanship by swatting him over the head with that useful and singularly effective implement.

Then the breeze failed, and while the little engine was slowly "kickin" the Osprey homeward, I fell asleep forward and dreamed of brutal blues that bit and of a crew that swung itself hither and yon with surpassing ease. When finally that crew sat before me, and - after twitching its eyebrows up and down, scratching with swift upward strokes at its ribs, and showing some amazing teeth - it calmly produced a cocoanut from one armpit and a banana from the other, I- woke up. And there, right beside me, was that crew, monkeying with the jibsheet, or some old thing, for the Osprey was very near her nest. 


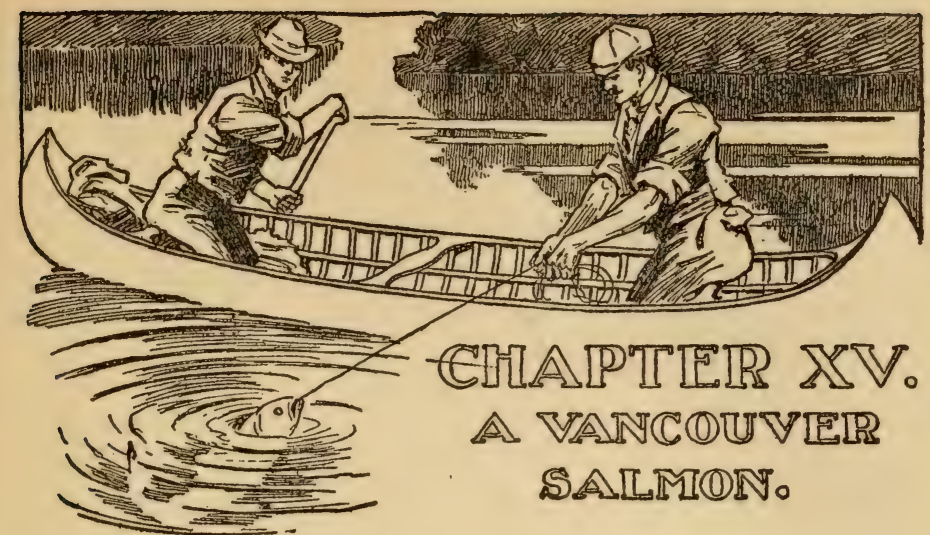

For months we had slowly staged westward. From the trout waters of Superior's grand north shore, through the moose ranges of eastern Manitoba, across the vast expanses of game-haunted plains to the Rockies, and thence westward ever through Nature's picture-gallery, where peak, cliff, and cañon combine in so many hundred miles of magnificence.

And at last, at the turning-point, we two stood beside the sheeny flood of Burrard Inlet, awaiting the sun's appearance above distant sea-mists. Slowly, like white-canvased ships, the snowy shapes of fog slipped their intangible cables and drifted seaward, until the last had vanished and we saw all the dreamy beauty of the coast.

Behind us spread the sudden straggling growth of lusty young Vancouver, yet showing traces of that conflagration which virtually wiped out the original town. Below our feet were the spidery webs of timbers supporting long irregular piers, among which flitted solemn crows, strangely tame to one familiar with the wary eastern species, and ever poking and prying among the ooze for what the 
tide had left. In front, a big, black coal hulk sullenly tugged at her cables, and beyond spread a noble expanse of shining water, a magnificent, almost landlocked harbor.

Away across on the farther shore, a white mass flashed - the Indian Mission and rude cottages of that strange, west-shore remnant of a people who claim not kindred with the dethroned bronze rulers of the great plains. Above the Mission, and as far as eye could range, towered a stately cordon of softly rounded, densely forested mountains, mighty masses of softening greens, grays, browns, and misting purples, their crests supporting the flawless blue, their velvet shadows stretching far down into the flood. These steeps are the seaward battlements of those Titanic rockworks piled in such magnificent disorder within the confines of British Columbia.

To the south the panorama of peaks dwindled and softened in grand distances to where that snowhelmed giant, Baker, gleams above the good state of Washington. To the north were "The Lions," couched in everlasting stone above forests of stately conifers; and beyond them purple peak after peak - stern interrogation-points, solemnly questioning the sky. Below, and much nearer, lay the rippling Narrows, the harbor entrance, above which towered the grimly hewn face of precipitous Brockton Point.

This point is one of the features of one of the loveliest reservations imaginable, - Stanley Park, Vancouver's special pride. Under a tangle of foliage strangely suggestive of the tropics extend nine miles of smooth shell road, the very thing for long tramps. The enormous growth of the conifers, 
ferns, and mosses is proof abundant of a kindly clime. Huge cedars suggest the famed big trees of California; gigantic firs, straight as lances, taper to green points near one hundred yards overhead, while every where in the deep shade rise fern fronds higher than a tall man's head to meet the ever present pendent beards of gray moss. Across the white roads ruffed grouse mince out of the pedestrian's way, clucking softly as they go with many halts and innocent glances. Firearms are not allowed within the park, and the birds know that safe cover is but one short leap away. And such cover! Crowding, graceful ferns, so tall that a ruffed grouse flushing near one's foot can buzz away unseen.

From the crest of the cliff of Brockton Point, the rough-hewn descent is so nearly vertical as to present an apparent overhang, and it measures more feet than a man could fall and live, even though he struck nothing firmer than deep salt water. Upon the green, moist boulders at the base at that time rested a most interesting wreck, the little Beaver. To that humble craft belonged the honor of being the first steam vessel to plough Pacific billows. She sailed round the Horn in 1836 , carrying her boiler and engine as ballast, the intention being to fit her up at Vancouver Island. Her commander was a sturdy Scot, and for reasons best known to himself he put in at the Sandwich Islands. The then prevailing monarch was a gentleman endowed with an unlimited cargo capacity, a late tropical evening complexion, and a curiosity like a well-auger. He heard of the peculiarities of the Beaver's works, and straightway craved to see the wheels go round. He 
ordered the captain to make those wheels go, or explain why. The hardy salt parleyed long enough to rig up a brass bow-gun and fill it full of small bolts and other odds and ends. Then he explained that he would blow the ham out of the Sandwiches if any trouble was desired.

So the Beaver safely swam away to her northern lodge to toil for the Hudson Bay Company, and her snorting and blowing struck terror to the soul of many an Indian from Astoria to Chilkat. Lieutenant Pender used her while making surveys and soundings of coast and waters. In I 889 the little craft was cast upon the rocks under Brockton Point, and there the poor bones lay gathering mosses and seaweeds for funeral shroud till I892. It was queer to watch great modern steam craft sweep past the Pacific's first power boat. Since the day I swam alongside in an attempt to get a peep at her interior, I've always had a tender regard for the Beaver, and it was something like a shock to read in ' 92 that the drowned one was to be haled to that all-grasping World's Columbian Exposition. But the Beaver had not forgotten the craft of her furry folk, so, presumably after she had heard of the intended moving, she waited for a great big roller and - just dived!

Before we had completed our observations a small boy ranged alongside, and remarked, "Note for you, sir." A new-made friend had read me aright, for the note ran: "Gla-hi-you-tillicum! I've got a brannew canoe that's never been used. If you care to christen her for me, she's at your service. Orders at boat-house."

"A Peterboro away out here!" was my first 
thought. I had not knelt in one for a long year. I said to my comrade:-

"W-, old boy, we ought to have a paddle together; it'll be prime poking about under those cliffs. What say you?"

W-, good, kind, big-hearted W-, was game for anything and at once agreed. As we were turning toward the boat-house, a tan-colored Siwash sped past in one of their queer canoes. W- said the man was going fishing.

"Going - what?"

"Going trolling; they catch any quantity of salmon in the Narrows when the tide is right."

"The mischief they do! Why didn't you say so before?"

"Thought you were a fly-fisher and wouldn't be interested. These salmon won't take a fly; they catch 'em with big spoon-hooks."

"W-, I'm going to catch a salmon. Why, I haven't caught a fish for a whole week - not since the mountain trout at Harrison Springs."

He was willing, so we hurried to the hotel and borrowed a heavy line, to which was bent a plain spoon, like a table-spoon, with a big hook soldered to it. Armed with this doubtful-looking outfit, we launched the canoe. She was a beauty, the paddles were just right, and it was a treat to kneel upon a handsome cushion in a spotless, richly carpeted craft, and send her flying over that sleepy water. As we neared the Narrows, other Siwashes in other queerlooking canoes began trolling, meanwhile grinning like wolves at our craft and evidently seeing something very funny about us. Presently one of them 
unceremoniously hauled in a fine fish, and Wremarked :-

"Best put out the troll; I'll paddle, but we'll never catch one. I never catch anything except colds and things like that; nobody ever catches things when I'm around. I'm a regular Jonah."

"All right, old boy; we'll presently catch a whale," and out went the troll.

Now W - was an old hand at the paddle, and he sent us along at just the proper speed. Within easy distance were half-a-dozen Siwash craft, and still their dusky owners grinned. Every now and then one of them would lift a kicking salmon, while with us it seemed as though my comrade's Jonah influence was no myth.

After an hour of back-and-forth work and continuous grinning by our dusky associates, we almost lost hope and edged over toward the Park. A point of rocky beach offered a safe place for the canoe, and I had begun to haul in line when there came an unusual drag. It was not a strike, but just a slow dragging weight as though the hook had fouled a mass of weed. I had struck from force of habit, and kept hauling in, little thinking of a possible fish. A slow, heavy pull warned me that whatever was on the hook possessed some life. Nearer and nearer it drew, and we became interested, wondering what strange, lazy victim was ours.

Next we saw a goodly fish of a bluish silver cast. It looked like a five-pounder, and, seemingly, it possessed the life and vigor of a five-pound can of white lead. Docile as a dog, it suffered itself to be drawn within a foot of the canoe, then poised a 
couple of inches below the surface to allow us to examine it at our leisure. Its jaws were quite arched and pointed, not unlike the beak of an eagle. Quoth W-, "That's a salmon and a good one; pull him in!"

I looked a moment longer and noticed that the fish was hooked foul, for the barb had pierced the side of its head, and it could not break away unless spoon or cord gave out. It had come in so easily and lay there so placidly that I despised it, and carelessly raised the head above water, and said: -

"Well, if this is a sample of your salmon-trolling, I don't wonder you hesitated to talk about it. Why, that big duffer is the worst cur ever I saw; he hasn't got enough sand in him to make a splash, let alone - "

Something had happened! For an instant I could not realize what it was. I knew I had raised the fish's head above water, and that the jaws had snapped once or twice. It must have understood and taken affront at my remark about its inability to splash. A quart of salt water struck me in the face, and still the fish splashed, and splashed, and splashed, sending showers all over us, flirting water with sudden sweeps of its powerful tail, as a bathing boy splashes with a hand.

W-, daintily garbed $\mathrm{W}-$, got mad. He roared and waxed abusive and tried to secure a paddle with which to slay the thing. I offered it slack, but it would have none, but merely wallowed about, splashing unceasingly. I strove to twist it aboard, but got deluged, and so did the cushions and the carpet, also W-'s natty suit. Then I got mad, hauled 
it close, got another pint of water, seized the head and strove to hold it still. Never had I tackled so strong a fish. It felt like a form of wet leather crammed with powerful springs all working independently, and I guessed how salmon are able to leap high falls and stem raving currents. It seemed the grip surely would squeeze the head from the body, but still the tail threshed and the spray flew.

At last I raised the fish, whereupon it gave a sudden unholdable wriggle, rapped my nose with its tail, then fell upon our carpet and began throwing handsprings in all directions. It flopped under W - and beat upon his lower attire, every blow leaving a welt of reddish slime. Then it rapped three hard knocks with the wonderful caudal, delivered all the blood it had left upon our carpet, and — died!

We stared in amazement for a moment, then Wopened and his speech was carelessly chosen.

"Steady, old boy, these canoes are cranky. Let's get on good solid rock and then air our views."

Such a washing, and scraping, and fussing as there was, before our late dainty craft and ourselves again were presentable. Only the scenery and a smoke smoothed our ruffled feelings. It was not until we had shoved off for the pleasant homeward way, and had cast burning glances at the dead thing, that $W$ - ventured to ask:

"Well, how do you like our salmon?"

"Canned! And the next time a bombshell full of beef blood fouls my troll, I'll cut the tackle! See?" 


\section{CIIAPTIEIR XVVI. WOQDD-DUUCIN ANID WOOD-DUCIK SIIOOIIING.}

OF the great order Anseres the family Anatide contains a couple of hundred species which have been grouped in five sub-families, viz.: the swans (Cygnina); the geese (Anserina); the sea-ducks (Fuligulina); the river-ducks (Anatina); and the fish-eating ducks (Mergince). Among the riverducks are found valuable and beautiful species, yet none more daintily arrayed than the wood or summer duck (Aix sponsa).

From Asiatic waters has come a small web-footed fop whose garb suggests a blending of Chinese and Japanese sartorial art. He is no mean rival of the wood-duck, and the same might be said of the rare and lovely Harlequin; yet if perfect specimens of the males of all three species lay side by side, in most eyes the wood-duck surely would find the most favor.

As is the case with so many other species, the male wood-duck sports all the finery in his family. By this is not meant that his trim small spouse is a bit of a dowdy, for that would be far from the truth. She is as dainty and tidy a wee madam as one could desire to see, but she is wise withal, and the Quakerish simplicity of her dress might well be 
imitated by some other ducks - but - um - I digress.

The notable peculiarities of the wood-duck include the rare beauty of the plumage of the male; the habit of alighting in trees; the nesting in hollow and not seldom lofty trunks, sometimes at a considerable distance from water, and the not infrequent carrying of the young from the nest to the nearest water. The adult plumage is as follows:-

Male. - Top of head and sweeping crest, golden green; sides of head, rich with purple iridescence; bill, short, reddish; irides, orange-red; from bill to end of crest extends a narrow, pure white line which passes above the eye, and from behind the eye to the end of the crest is a second white line, the two in sharp contrast with the lustrous surroundings and producing a striking effect; cheeks and sides of the upper neck, violet; chin, throat, and collar around the neck, pure white, curving up in crescent form nearly to the posterior part of the eye. The white collar is bounded below with black; breast, dark violet-brown, marked on the forepart with minute triangles of white, the spots increasing in size until they spread into the white of the belly; each side of the breast is bounded by a large crescent of white, and that again by a broader one of rich black; sides, under the wings, thickly and beautifully marked with fine, undulating parallel lines of black, on a ground of yellowish drab; flanks, ornamented with broad, alternate semicircular bands of black and white; sides of vent, rich light violet; tail coverts, long, hair-like at the sides, black glossed with green; back, dusky bronze, reflecting green; scapulars, 


\section{Wood-Duck and Wood-Duck Sbooting 207}

black; tail, dark glossy green above; below, dusky; primaries, dusky, silvery without, tipped with violet blue; secondaries, greenish blue, tipped with white; wing coverts, violet-blue, tipped with black; legs and feet, yellowish. Total length, I8-20 inches.

Female. - Head, slightly crested; crown, dark purple; behind eye, a bar of white; chin and throat, white; head and neck, dark drab; breast, dusky brown, marked with large triangular spots of white; back, dark glossy bronze brown, with some gold and greenish reflection; speculum, greenish, like the male; the fine pencillings of the sides and the hairlike tail coverts are wanting; the tail also is shorter.

While it is extremely difficult to give anything like an accurate pen picture of a fowl which glitters with metallic lustre that changes from bronze to purple and golden green with every play of light, enough has been said to bear out the statement that the wood-duck is exceedingly beautiful. As it may easily be tamed, it is not at all unlikely that within a few years it will be an attractive pet upon many private waters, where certainly it is well worthy of a place. It is a summer resident, its range being North America, and it winters in the Southern states. It usually comes North early in April and at once seeks ponds, creeks, and small rivers bordered with more or less standing timber which offers in hollow trunks, or large limbs, the favorite sites for the nests. The note of this duck is a softly sweet, rather long-drawn "Peet-peet," the alarm note a musical "Oe-eek-oe-eek!"

When a pair of wood-ducks find water and a hollow tree to suit, little time is lost in preparing the 
nest. This task and the covering of the eggs are performed by the female, for to the best of my knowledge the male does little more than sit around on handy limbs and look pretty. During the period of nest building, and while the duck is laying, he is the beau ideal of a handsome and loving cavalier, ever attentive and seemingly most anxious as to her whereabouts should she happen to get out of his sight. But with the waning of the honeymoon he seems to feel rather bored with the whole business, and gradually he gets clubby - i.e. wanders from his own fireside and hunts up another drake or two to help him loaf away the summer. The busy little duck keeps her own counsel and "sits tight" on the dozen or more highly polished ivory-like eggs crowded together in a bed of soft decayed wood and down from her breast.

Quite frequently the nest is at the bottom of a hollow several feet deep, and no doubt the strong, hooked claws of the wood-duck are a special provision for the oft repeated climbing out of the hollow. The newly hatched young are extraordinarily active, and so soon as they are dry and ready for their first peep at the outside world, either the mother carries them in her bill to the ground, or they scramble to the front door and reach the earth as best they may. I have kept close watch on a number of nests, and by the aid of an excellent glass have observed many details of the interesting ceremonies of Evacuation Day in Woodduckville. One nest in particular was in a huge hollow willow which had a decided cant to nor'ard and which stood perhaps twenty yards from the stream and leaned from, not 


\section{Wood-Duck and Wood-Duck Sbooting 209}

toward, the water, thus reversing the usual habit of such trees. In this tree were hatched eleven young; and their first flitting was as follows, as notes then taken show:-

The drake was conspicuous by his absence, for he was neither in the tree, in any near-by tree, nor on the visible half-mile of stream. An observation late the previous afternoon had proved the existence of one newly hatched duckling, which lay with the eggs about a foot below the entrance. Owing to the peculiar cant of the tree, it was possible to see the eggs and learn what was going on without any feeling for information, which is a dangerous experiment with the eggs of most birds.

Bright and early, therefore, the following morning I took position against a stump on my side of the stream. From this point the hole in the willow was plainly exposed, and with the glass I could see even the small scratches made by the duck's claws on the barkless wood below the doorway of her home. It was nearly ten o'clock before the sun shone fairly into the hole, and a few minutes later the duck came forth and stepped nimbly along the sloping trunk for perhaps a couple of yards. She seemed anxiously alert, and for some time stood erect, twisting her neck about as though examining every yard of the surroundings. Presently she scratched her head with an action so comically suggestive of a certain class of human thinkers, that I was forced to smile. Evidently, she was a bit worried, but whatever may have been the troublesome problem, she presently solved it to her satisfaction, for she began to preen herfeathers in a rapid and unusually 
energetic manner. Her toilet completed to her liking, she gave her tail a couple of quick flirts from side to side, then ran rapidly to the hole.

At the edge of it she paused as though staring within. It is possible she uttered some low call to her babies - her appearance suggested it, but I was too far away to hear. Finally, she thrust her head and neck into the hole and bent farther in until only her tail was visible. Clearly she was reaching down as far as she could. A moment later she straightened up and trotted down the trunk. Held by her bill was a duckling, which she released when still a couple of yards from the ground. It remained clinging to the bark exactly where she placed it. As she turned about, a second duckling, and then a third came out of the hole and began the descent. By a series of sliding scrambles they reached the spot where she stood and for the time made no effort to go farther. She remained motionless, seemingly intently watching the hole. Three more youngsters soon followed the leaders. Sliding, creeping, clinging, they covered three-fourths of the trip - then one missed its hold and fell to the ground - perhaps ten feet.

In an instant she was after it, and for several seconds she hovered pigeon-like above it. I feared it had been injured, but presently it trotted after her as she moved to the foot of the tree. Meanwhile two more had left the hole, one reaching its mates on the trunk, the other stopping halfway and apparently hanging by a foot as though a claw had got fouled in the bark. Presumably it made some outcry which she could understand, for she ran up 


\section{Wood-Duck and Wood-Duck Shooting 2 II}

the trunk, released it, and carried it to the foot of the tree, fluttering directly down instead of walking past the others. No sooner had she deposited it than the lot on the trunk made a move to follow. From their position lay the steepest part of the trip, and it was made in one quick slide.

The mother now showed signs of extreme anxiety. For some distance about the tree the sandy soil was practically bare, and clearly she did not relish the idea of having her youngsters too long in such a place; yet there were three in the nest. One of these settled the question by coming out and making the descent in one grand leap. It never hesitated, but simply sprang into the air, and with rudimentary wings and small paddles stiffly spread, it shot down to the sand and immediately ran to the others. The mother then leaped upon the trunk, ran up to the hole and went in.

For perhaps five minutes she remained inside, and when she reappeared she held a young one, seemingly by the skin of its back. With this one she fluttered straight down, and at once released it. This left one in the nest.

Most interesting performances present something strong as the closing act, and the last baby duck surely was the star of the troupe. While his mother was attending to his small relative, this chap (I'll bet it was a drake!) came out of the hole. For perhaps ten seconds he stood at the entrance as if waiting for all hands to give their earnest attention; then he started! No clawing at the bark, no fearsome flinching, nor any trace of hesitancy - he was not that sort. Whether or no he lost his balance, I am 
not prepared to state - anyway down the trunk he came, running like a young grouse and gathering speed every skip. The pace, however, was a bit too good to last. Halfway down he tripped, or something, and in an instant he was spinning end over end. Rumpity-bump-biff-bang! Down he came, his last parabolic flight landing him squarely on top of the small group of brothers and sisters. He fell more different ways at one trial than anything ever I saw, yet the bouncing did not appear to hurt him in the least. I suspect he was the one last hatched, for he seemed much less strong and nimble than the others.

Shortly after his spectacular arrival, the mother led the brood straight across the exposed strip at a smart pace. All were running their best before the cover was reached, mother and young appearing to have an equal dread of the bare sand. In a few seconds they were in the cover next the water, and shortly after in the water itself. I could not see them enter, but in a short time the mother sculled slyly along the edge of a mat of weeds. She swam deeply, as though striving to make herself as inconspicuous as possible, and at her tail were the young all crowded together like a small woollen mat and occupying no more room than might have been covered by an ordinary dinner plate. Under a tentlike mass of wild grape-vines she halted and I went down to my canoe, for I was anxious to see a bit more of them.

Had I not marked their hiding-place, the ducklings never would have been discovered. As it was, there was need for the sharpest scrutiny to locate 


\section{Wood-Duck and Wood-Duck Sbooting}

them after the mother had flown. She did not go more than forty yards before pitching to the water, and she was in a perfect torment of anxiety. The young were packed together under the vine roots, but I managed to drive them all out. I was curious to learn if they could dive, and so soon as they had been forced clear of the cover, all but one answered the question by promptly going under. The one fellow - for I knew he was the "fat boy" who had flip-flapped down the tree, strove mightily to go under, too, but he couldn't. He could put his head under and up-end all right, but to save his life he couldn't induce his fluffy posterior to follow the head. The wee paddles worked, bravely kicking drops of water at a great rate; but either the coat was too dry or the machinery too new, for the best he could do was to circle about in an irresistibly comical manner. Finally I laid hold of the fleecy tuft that served for his tail and lifted him to my knee. His beady eyes had a peculiarly wild gleam, and his tiny paddles pressed with astonishing firmness against my leg. Happening to touch his funny little bill with the tip of a finger, his mouth at once opened to its fullest extent. His expression then was quite savage, and an instant later, to my amazement, he actually made an attempt to bite.

"You're a brave wee drakie, all right enough," I said to him as I attempted to lift him preparatory to turning him loose. The twin paddles, however, had a curiously firm grip, and the sharp nails clung to the cloth. Then I remembered he was a treeduck, and better understood how his elders could perch, or run along a limb at will. 
"Guess I'll wet you, son, so's you can get under next trial," I remarked as I shoved him under. At once the small paddles were busy, and when a few seconds later the hold was relaxed, he sped deeper down. For fully a minute there was no sign of him, and my heart sank, for there was a nasty possibility that his terror might have driven him too deeply among the bottom growths. Then I remembered something. A hasty stroke of the paddle shot the canoe ahead, when a glance astern detected the small rascal tossing in the swirl and kicking his prettiest to submerge himself. He had first come up under the canoe, and probably had remained with only his head above water for some seconds. He swam to the bank in short order, and unless he happened to be among those that tried to fly through some of my lead the next autumn, I never saw him again.

A peculiar capture of a half-grown drake may be worthy of reference. My comrade upon the day in question was then a strapping young man-peace be to his ashes! and we were fishing for black bass on the Thames River, a stream beloved of woodduck. Where we were the water was perhaps eighty yards broad and twenty feet deep. The time was early August, and the day very sultry. We two were, perhaps, the greatest water-dogs in the county.

"I can beat you across for a dollar!" poor Kit suddenly exclaimed. He knew he couldn't, and all he really meant was to have a swim. In mighty few seconds we were peeled to the buff (umber would have been nearer the truth!) but before we could plunge he yelled, "See the wood-ducks!" 
Wood-Duck and Wood-Duck Shooting 215

Thirty yards away half-a-dozen flappers were pattering across the stream, and the way we hit the water was a caution. We returned to the surface, going at full speed and halfway across - as it proved just far enough to head off the last duck. The others no sooner reached the bank than they sprinted to cover like so many Bob Whites. Because wise men garbed only in freckles and sunburn never chase through rough cover, those ducks were safe; but not so the lone one.

"Give it to him!" I yelled, and we foamed in pursuit.

The unfortunate duck didn't know enough to go back to the bank it had left, or its sole desire was to follow its kin, for it refused to turn. Kit dashed straight for it, while I edged nearer the desired bank. The duck scuttled ahead a few yards, then dived. Instantly I went under a few feet, then paused and stared toward the light. After half a minute's wait, I rose hunting air, and within a yard of the duck. A wild grab missed by a narrow margin, and again I went under and waited. The duck as it vanished was headed from me, but I knew their tricks. Within thirty seconds or so, as I stared toward the light, a long black thing hove in sight, headed so as to pass directly over my face. I could distinctly see the head, neck, half-spread flapper wings, and the kicking feet. It was not travelling very fast, and - this meant seriously, mind you ! I thrust up my hand and grabbed the neck. Before I got to the surface I learned something about woodducks' claws - they can scratch like fury; but I had the drake, for such it proved to be. Kit's first 
remark was, "Bet you got him!" and when I held up the duck, his whoop of delight might have been heard a mile away. The bird wasn't injured a particle, but it was "scared stiff." I got it safely home and kept it until the first of the winter. It soon became as tame as a pet chicken. To my great sorrow a mink killed it one night in its pen.

The shooting of the wood-duck is a sport I greatly fancy. There are three methods, which may be termed "jumping," "poling," and "flight." About the time of the first light frosts, the ducks are much in the vine-hung trees that overhang slow streams and ponds. The small wild grape is then the attraction. When not in the trees, the ducks have a habit of skulking under the brush of the banks and quiet coves. They also like to stand upon almost submerged snags. When alarmed in such places, they may at once spring, or go trotting like grouse to the brush.

The man intent upon jumping wood-duck should have a good canoe and a light, handy gun - a good quail gun is the very thing. I kneel and have the gun resting in a crutch, so the heel-plate just comes between my knees. So placed, one can get it with the least waste of time, and it is wiser to waste no time when a wood-duck springs. The paddle should be made fast by a yard of stout cord; it may then be dropped and recovered at will. The quickest way to get rid of it is to drop it clear. So equipped, one may steal up mile after mile of stream, keeping a sharp eye upon trees and low cover ahead, and hands ever ready to drop the paddle and seize the gun whenever the tremulous "Oe-eek-oe-eek!" tells the glad tidings. 


\section{Wood-Duck and Wood-Duck Sbooting 217}

It is indeed pretty sport, and none too easy, for only a smart and accurate shot can hope to excel at it. The surroundings, too, almost invariably are very pretty, for the winding water every few minutes reveals a new vista of noble trees and drooping vines. Occasionally, a small flock of ducks, humming downstream, dart around a bend without the slightest warning. Then is the moment for the swift man who can let go with one hand and take hold with the other, and shoot without bothering about getting the gun to his shoulder.

The first flight of wood-ducks from the streams usually extends no farther than to the nearest rice marshes. There they frequent the lily-choked ponds, especially those which have a few old rat houses. The wood-duck seems to love the top of an old rat house, presumably because it is apt to be the most convenient place for a sun bath. The marsh ponds can best be reached by pushing, i.e. propelling the canoe by means of a long punting paddle which may be set against submerged roots and other tolerably firm stuff.

Next to jumping, I prefer flight, as follows. So soon as the young ducks are able to fly strongly, they are apt to start about sunrise and go far up the stream to some special feeding-ground, or it may be their night resort in some small pond in field, or wood, or some particular cove of a stream. To these they return about sunset, straggling in singly, by pairs, and now and then a whole brood together. A man properly placed beside the night resort may enjoy perhaps half an hour's shooting of the liveliest description. Again there may be half-a-dozen 
ponds, etc., near together, while the stream extends for miles above. Then it is no bad scheme to take post on the bank of the stream and, say, a mile above the night resorts. The ducks usually follow the stream until they are close to their chosen spot; hence a man in the right place may have chances at all the fowl of a group of night resorts. I well remember one old "hide" of mine. It was on the very crest of a cliff-like bank of a narrow river. About a mile below were two big ponds in the open fields and beyond them nearly one hundred acres of wet woodland. These places were in high favor, and toward sunset the ducks would come streaming down from feeding-grounds higher up.

Then the sport depended upon how the fowl arrived. If, as sometimes happened, they came in large groups, or too closely following smaller lots, the shots at the first were apt to alarm others and so spoil the fun. But frequently they came straggling along in well-separated fives, sixes, and sevens, with an odd one, or a pair, every now and then. Then was there exceeding great joy in the hide, swift action, and the keenest of watches upstream, for it might happen that twenty or more shells would be used before the light failed, and the fellow who uses that many shells upon wood-ducks and doesn't have fun and incidentally knock down a fair percentage of fowl, should be deprived of his yellow jacket.

The last bird I killed will not soon be forgotten. It was in October, yet the weather was like midsummer.

"Too late, man - what ye thinkin' about?" ex- 
claimed my host, when I had suggested a joint expedition up river.

"I'll go anyway, this afternoon, just for a paddle," I replied, and I went.

The stream was deserted, yet the five-mile trip was wondrous pleasant. At the turning-point I lingered long, merely lounging in the canoe, for farmers along the way had all told the same story "Ducks had been fairly plentiful, but all had gone to the marsh."

I suppose old memories had a deal to do with it, for somehow I fairly longed to see even one of the dainty beauties that formerly traded up and down that water. It was a perfect Indian summer day, the water like glass, the sky steel-blue, and over all the magic haze which screens the death of the bleeding leaf. Great walls of painted foliage were mirrored in the sleeping water, and as I looked up the old stream from the old point of view, I thought, "'Tis indeed wondrous fair - why couldn't just one of the old wood-ducks have held over for my benefit if but to complete the picture."

He must have known - have purposely delayed rather than have me disappointed. I saw him first, and as there was no time for getting to cover, I knelt in the canoe right in midstream. He saw me, but all he did was rise a bit and "Oe-eek" for more steam. When he was almost overhead, for an instant I caught the gleam of his sunlit garb, then, allowing at least ten feet, I pulled. He got it so fairly that all he did was set his wings and hang for one instant with the sun glorifying him, the misty blue above, and the billows of glowing foliage upon either hand. 
For some minutes I almost wished I had missed. Then I paddled after him, lifted him from the water and laid him gently upon my coat. He was the prettiest drake ever I killed in the fall, and all I need do is to raise my eyes to his glass ones and see them full of the same old question - "How the devil did you manage to fluke my undoing?" 


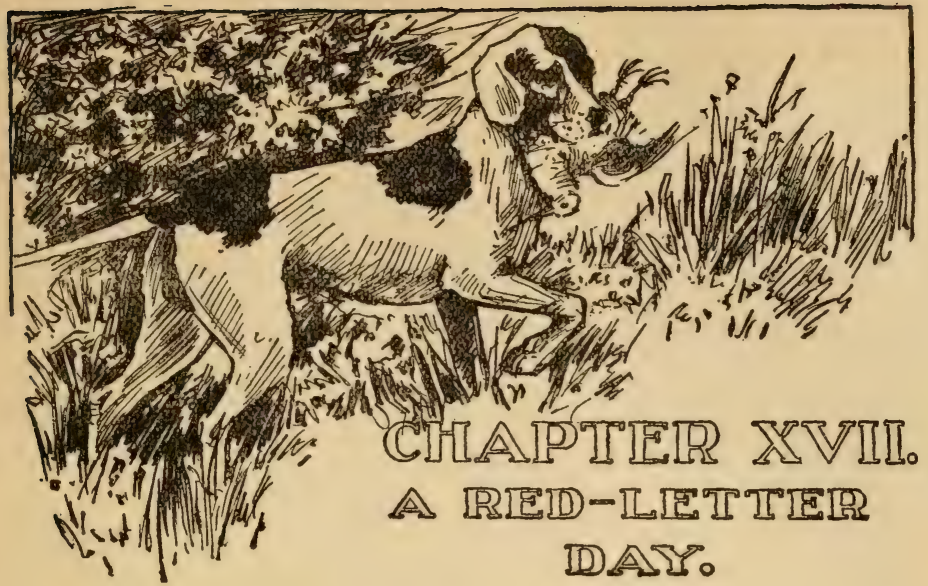

THE sun looms large above a sea of gauzy haze which piles like airy surf against the forest's rim. It is a windless, dreamy morning, rich with the magic of the Indian summer, the glory of painted leaves, the incense of ripe fruit. In the full fatness of autumn's latter days the world is songless, silent, fat. Those things which sleep - that drowse the long, white silence soon to be - are round well-nigh to bursting. Those things that durst not face the nip of steel-skied nights have fled to kindlier climes, while those other things which neither sleep nor flee are revelling in a rich abundance. They know what must come when Kee-way-din whines about their brushy eaves and the strange, cold white feathers fall. They know that the brushy and still leafy cover will be flattened and that the white wolf of the North will plunge and ramp and howl across far leagues of whiteness. They know the present business of their kind is to eat - eat till craws and skins are tight as drumheads, to wax fat because fat things do not freeze, while they can, if need be, doze 
for days when times are bad. All this eating and fat content is lazy business and sleep lasts long.

$\mathrm{Up}$ in the pleasant room, too, Sleep herself sits by a narrow cot upon which lies a silent figure. The kindly goddess knows that under her spell men do no wrong, and so, with light hand laid across his eyes, she sits and watches. Through open windows streams a scented air, fruity from near-by orchards and spiced with the breath of drying foliage.

Thump! A big apple parts its failing stem and strikes a hollow roof. The figure stirs and Sleep flies on soundless feet. Gradually the man gets himself dressed, and then he looks the workman. The loose cord breeches closely match the broadsoled, flat-heeled knee-boots; the sweater has the shade of the dried grass, and the old canvas coat admirably matches it. 'Tis a marvel, that coat - a thing of beauty and a joy forever to its owner a horror unspeakable to his female kin. One had described it as "A snarl of pockets held together by some remnants of filthy canvas," and the owner had merely smiled. To him every stain upon it was a precious thing, a sign-board pointing to a dearprized memory, and he wouldn't trade it for the mantle of Elijah. Once, a fair young thing, a frequent guest, who was clever at giving the last touch to ties and an invaluable adviser in regard to manicure sets, had declared she'd "wash that horrid jacket!" and thus a dimmering possibility of a a - oh! bother - it didn't come off, anyhow!

But the little woman who met him this morning was not of that sort. Once, long before, he had explained to her the difference between shooting for 


\section{A Red-Letter Day}

count and shooting as a sportsman should, and why there was no advantage in getting upon Bob White ground too early. She knew that fifteen birds was his limit so far as that particular game was concerned, and she also knew that the fifteen and perhaps some other game would load that coat at night, if all went well. So when he had nearly finished breakfast, she slipped away, to presently return amid a tumult of scratching claws and gusty breathing.

"Here - he - is - and - I - gave - him - just — three - bits!" she panted, as the strong brute strained at the chain in his eagerness.

"Down - you!" muttered the man, and as the quivering form sank promptly, he continued "Mater mine, thou fibbest - he don't lick his chops that way after straight bread."

"Merely an atom of gravy, dear - just a drop was kept, and the bread is so dry and he chews at it so."

"Grease-faugh! will you never learn?" he growls, but his eyes are twinkling and he has to avert his face to keep from laughing outright, for this question of dog-fare is a rock upon which they regularly split. Right well he knows that Don has had his bread, a trifle of meat, and perhaps about a pint of soupy stuff to boot; but he wisely makes no further comment, for the mistake was lovingly made.

And so they fare forth, a varmint-looking team, both lean and hard, the long, easy stride of the man hinting of many days afoot, the corky action of the dog proving him sound and keen. 'Tis true his ribs show as though his hide covered a spiral spring, but his white coat has a satiny lustre, and he 
puts his feet down as though such things as thorns and burrs had never been. Behind them stands the little figure watching with moist eyes, for one is hers and the other belongs to one of hers. Though they went and returned one thousand times in safety, — still — still — it might - be. Wonderful are thy ways, $\mathrm{O}$ woman!

At the corner the tall figure halts and right-aboutfaces with military precision, the gun is whipped through the salute, and at the instant the white dog rises erect upon his hind feet. Both man and dog know that all these things must be done before rounding the turn, else the day would not be all it should. A kerchief flutters in the distance, then they pass in a few strides from town to country.

Before them spreads a huge pasture, beyond that a grove of mighty trees, and beyond that the shooting grounds - farm after farm, with here a bit of woods and there a thicket. For miles the country is the same, and through it all, in a bee-line, extends the double track of an important railway. Along either side of this runs a broad ditch, now bone-dry and bordered with low cat-briers. These and the ripe weeds standing thickly in the angles of the railfences form rare good cover for scattered birds.

"Well, Mister," says the man to the dog, "guess you'd best have a pipe-opener right here." $\mathrm{He}$ waves his hand and clucks softly, and the dog sails away over the short fall grass. A judge of dogs would watch this pointer with solid satisfaction. So smooth is his action and so systematic is his method of covering ground, that his tremendous speed is not at first apparent. But for all that he is 
a flier which few dogs can stay with, and best of all he can keep going for a week if need be.

Of course, he naturally was a fine animal, blessed with courage and brains a plenty, but his owner's method - "keep sending 'em," as he termed it - has done much to develop the speed. Needless to say, at the forward end of that dog is a nose - for woe unto the animal that would attempt such a clip without the very finest thing in the way of a smeller.

Half an hour later the man halts on top of a fence while the dog takes a roll. They are now on the edge of the good ground, and both feel just right after their preliminary canter. The man fills his pipe, gets it nicely going, then looks at the gun across his knees. It appears almost like a toy; but its small tubes are of the best and can throw lead with amazing power. Almost plain, but perfect of its pattern, that gun cost about three times what an unsophisticated person might guess as its price, and, as its owner declared, it was well worth the money.

"Now, Mister," says the man, after a bit, "there's rag-weed, standing corn, and thicket - which would you advise?" The dog sits up and stares with loving intentness, and the man continues - "When a lemon-headed fool-dog looks at me after that manner he certainly means standing corn, so here goes." At the words he lets himself down, while the dog darts away. Soon he is into his regular stride and beating the ground with beautiful precision. The man watches and nods his head as he mutters, "That rat-tailed rascal's going great guns to-day, he'll have 'em befo - " In the middle of a stride the dog has halted as though smitten by lightning. Some 
message of the air has reached that marvellous nose, and the grand brute stands as though carved in marble. There was no roading, no feeling for it, just an instantaneous propping and a breathless halt. "That's funny," mutters the man; "I'd have sworn - ha!" There is an abrupt rising of a brown, hasty-winged thing which goes darting for a distant cover. At the sight the lazy man suddenly changes. The little gun leaps to the level, and before the butt has fairly touched the shoulder, the quick smokeless has hurled its leaden greeting. The bird goes down, unmistakably clean killed, while the dog slowly sinks to his haunches. As the man reloads, his face fairly shines with joy. "Fifty yards if an inch," he says to himself, "and a bruising old hen at that. Who'd have expected a woodcock this time of year and away out here?" Then he goes to the dog and clucks him on.

As the dog has seen the bird fall, he merely makes a few bounds forward and again stiffens within two yards of an unusually large female woodcock - one of those choice birds only occasionally picked up at the tail-end of the season. "Don't like that, eh?" laughs the man as he holds the bird near the dog's nose. The grand eyes are bulging with controlled excitement, but the shapely muzzle is wrinkled into an expression highly suggestive of disgust. "Wish I understood that. It's funny, but you don't like a dead cock though you'll stop on 'em fast enough when alive - eh, old boy?" chuckles the man. "Here, take it," he says, and the dog obeys. "Give it to me," continues the man, and the dog promptly drops 
the bird into the hand, then wrinkles his chops as though an unpleasant flavor remained. It's a grand bird, old and fat, and the druggist's scales later prove it to weigh full eight ounces, an extreme weight for even a female, which is larger than the male.

When again started, the dog sweeps away to a low-lying bit where the withered corn is taller and thicker. Here he circles rapidly, stops for a moment, then stands looking at his master. The man moves over to him, and closely examining the ground presently detects half-a-dozen small hollows and a tiny brown feather. "Flushed, eh?" he says to the dog, and evidently the latter agrees. Now the man's own tracks show plainly, there are no other bootmarks, nor has he seen an empty shell anywhere; so he knows the flush has been owing to natural cause. "Mebbe hawk," he says to himself. "If so, where?" His eyes rove over all the surrounding cover and settle upon a clump of thicket in a corner. It is about far enough and certainly looks promising. Away goes the dog as though he could read the other's thoughts. As he nears the edge of the cover his style changes. The smooth gallop slows to a steady trot which presently alters to a majestic march. Higher and higher rises the square muzzle and up and up goes the tapering stern, while he steps ahead as though treading on tacks. Two yards from the cover he halts with lifted foot in the perfection of the old-fashioned stylish point. "You beauty!" says the man, his eyes flashing with delight. Then he goes to the wonderful white form which, hard 
from set muscles, yet quivers with the tenseness of sudden excitement. The man, too, feels the magic of the situation. His eyes gleam and his teeth grip the pipe-stem as if they would shear it off. His heart thrills with rapturous anticipation and his strong hands grip the gun ready for instant action. Right well he knows that the pointer never draws like that or raises head and stern so high except for serious business. A dead leaf falls ticking through the tangling twigs, and at the first move of it the dog gives a convulsive twitch, while the gun flashes to the level and down again. A smile flickers in the keen eyes as the man moves a step nearer. No matter which way the game may go, he is bound to have a fair chance and he knows it. The cover is none too thick for even a straightaway drive, while all other directions mean the broad open. He clucks softly to the dog, but there is no responsive move-clearly this is a serious case. Could it possibly be a-? Ah! the roar of him, as he tore like a feathered shell through the densest growth! Oh! the beauty of him, as he curved into the mellow sunshine, his dainty crest and plumes flattened with speed. And, ho! the smashing thump of him as he hit the ground some thirty yards away. 'Twas a brave dash, Sir Ruffs, but risky withal, to dare that sunny open in defiance of trained eyes and nervously quick hands. Was it yonder mat of new clover-tips, or the red fruit of the brier-rose, which coaxed you here a fourth of a mile from your woodland stronghold?

But the dog is eager to be off. The languid air, scarce drifting in its lazy mood, is tattling something. 
There is some unfinished business, which the strong scent of the expected grouse had interrupted. Now, as the dog slants away, the square muzzle rises higher, and the eager stern whips frantically. Shorter and shorter grow the tacks, until the advance steadies to a straight line. Soon the gallop slows to a canter, a trot, a stately walk. With head and stern held high, on he marches until fifty yards have been covered. Then he suddenly stiffens, while the quivering nostrils search the air for positive proof. His erstwhile gusty breathing is muffled now, his jaws slowly open and close, while the marvellous nose seems to be feeling - feeling for a something rarely pleasant. Then on again, slower and slower, till he seems to fairly drift to his anchorage. Then his hind-quarters sink till he is almost on his hams.

Has he got them? Man, if you'd ever followed that dog, you'd know he had 'em. When you see that long draw and the squatting finish, bet your gun, or your wife, or whatever you prize most, that it's a bevy and a big one. Scattered birds he will pin in all sorts of fancy attitudes as he happens upon them, but when he gets right down to it, that signifies a wholesale order. The man moves up within a foot of the stiffened stern. For a moment the tenseness is dramatic - then - whur-r-r! Something like a mighty shell loaded with feathered baseballs appears to explode in a patch of dried grasses, and the air is filled with humming missiles. Even in the roar and electric rush the trained eyes mark slight differences in coloration, and the trim tubes swing from one bird to a second with a smooth rapidity which betokens years of practice. Two 
birds fall a few yards apart, and as they turn over in the air, the man notes the flash of white and knows his lightning choice has been correct. As he moves toward them, there is a sudden hollow roar, and a lone bird rises from his very foot and goes whizzing toward cover. The gun leaps to shoulder before he can check it, but it is promptly lowered. "Go on, you old seed-hen and do your best next year," he chuckles, as the brown matron strives to set herself afire by atmospheric friction. Her course is wide of that taken by the brood, but he knows she'll call the stragglers to her ere the shadows fall.

And they will be stragglers. Of the twenty strong beauties that roared up ahead of that first point, her sweet, insistent "Ca-loi-ee! ca-loi-ee!" will muster but four when fence and thicket blur together in the scented dusk. Instead of doing as she had told them time and time again - instead of plunging headlong into the convenient woods, her headstrong family has whirred across the open and dropped here and there in the well-known resort, the railroad ditch. Hither they have come day after day until the awful, clattering trains have lost all terrors. In the broad ditch are pleasant runways and much useful gravel of assorted sizes, also cosey, sunny spots, the perfection of dust baths. Here, too, are many unaccountable stores of grain, choicest of corn and wheat, which seem in some miraculous manner to appear there all ready for eating. What better place could there be?

The man looks at the dog and grins with unholy joy. The dog looks at the man and seems to un- 
derstand. Oh! they are a precious pair of rascals, are these two.

"You old Judas," says the man, "we'll do things to 'em now. It looks like fifteen straight - eh?"

And the dog cuts a couple of fool-capers, which is his method of evincing a devilish approval. Then the pair of 'em move on after the misguided birds.

Whur! Bing! Whur! Bing! It is almost too easy. Shooting in that ditch where cover is barely knee-high with a high embankment on one side and a stiff fence on the other, is something like shooting into an enormous funnel - the shot has to go right. The dog does little more than trot from point to point. Bird after bird rises and is cut down with painless exactitude. Presently two start together, only to be dropped by a quick double-hail. Then one curves over the fence, but a rising mist of downy feathers tells that he got it just in time. Then another pair, and as the second barrel sounds, a third rises. The cases leap from the gun, a hand flashes to and from a pocket - Burr!

"Here's where we quit - that makes fifteen," says the man, as the last bird is gathered. He sits down on a convenient knoll, pushes his hat back, and grins at the dog. That worthy, after a hesitating forward movement, which would indicate his belief that "There's more," also sits down and stares expectantly at the grimy coat. "Yes, I'll give you half. You've done mighty well, and for once it's fifteen straight," chuckles the man as he produces the sandwiches. The dog gets a bit more than half, for this is a red-letter day. Then the pipe comes out, and for half an hour the pair of 'em lounge in 
perfect peace. Little do they know or care about trouble. Twin tramps are they, heedless of the burdens of life, careless of its future. Sufficient for them that the afternoon sun is warm, the grass thick and dry. Naught care they for the five-mile homeward trudge, for neither is more than comfortably tired, and when they rise refreshed they will stride away as though they had just begun.

And the little woman will have two glorious meals all ready, for she knows what each can do in that line when thoroughly in earnest. And she will be almost sinfully happy, for the first glance will tell that things have gone well for at least one November day. 


\section{CILAPTER ISVIIII.}

\section{IPICKRIED FEROM TIUIE}

\section{IPRAIIIIE PPROVINCIE.}

To the hotel in Winnipeg came Thompson and Monroe, and within half an hour they had me stuffed so full of sporting possibilities that I scarce could get on my sweater. To avoid useless details, I'll merely say that within twelve hours we had reached an insignificant station from which we were to drive to the rough shooting-lodge which stands alone beside the big bay which marks the southern end of Lake Manitoba.

"Here we are! Change cars for Clandeboy, Tealtown, Bluehillburg, Redheadhurst, and all webfooted points! Passengers going east will walk, I reckon!" shouted Thompson. So far as I could see, the alleged station consisted mainly of primeval peace, poplar, and future possibilities; but there were small railway buildings, also a modest combination of general store and hotel, which presently proved no bad place.

"Looks a bit rough, but it's all right, eh?" chuckled Thompson. "Can't imagine what's gone wrong with Batteese - never knew him to be late. I'll have to - no, I won't either, for yonder he comes!" he concluded, and we saw far away a team emerging from the brush. Then a second team 
appeared, and the two jogged forward at the tireless all-day gait of the northern ponies.

"Now we'll get a square meal, give the nags a rest and feed, then hit the trail. It's a longish drive, but we have a glorious day, and there'll be a bit of fun along the trail, and a chance to try out our tenderfoot, or my name isn't Thompson. All hands to the grub-trough!" he ordered, as he led the way to what proved a first-rate meal. After that we smoked, and I took a look at the surroundings. These presented a picture of wildness. In all directions spread the same patchwork of brown grass and slim, close-crowded poplars, their dwarfed trunks showing silver-white like the beautiful birches of farther south. To the four points of the compass ran trails as black as ink. They looked not unlike cracks in a brown crust, and their well-worn condition hinted of the Breed villages, white settlements, and large farms which lay in three directions behind the shadowy walls of poplar. In the fourth, our route, was big Lake Manitoba and its famous bay.

These form a paradise for the wild fowler. Amid long leagues of silence, where the brown grass spreads like fur over billowy undulations, sleeps the great lake. Now and then a summer squall hisses across the broad open, and sends the white suds growling up easy slopes of sand, the chosen promenade of countless shore-birds; but, as a rule, the shining water sleeps as though awaiting the advent of some magician who might command something like sustained activity. Where the lake's southerly rim is broken to loop the noble bay, all semblance of sandy beach is lost. Instead, the characteristic 
short, bronzy plains-grass creeps to the edge of moist, boggy soil, and there the growth changes. A few yards beyond the firm ground begins a region of reeds which spreads for many miles. In most places the line between grass and reeds is sharply defined by a margin of the blackest of yielding ooze, beloved of the Wilson snipe and his nearest kin. The reeds are a marvel of rank luxuriance. A tall man standing in a canoe occasionally can peer across leagues of lonesomeness, the brown monotony only broken by the winding streaks of channels and the flash of half-revealed ponds. A tenderfoot probably would exclaim, "Get me out of this grass cemetery, for surely here nature has died."

During a ten minutes' scrutiny he might see no sign of life, yet his idea of that damp desolation would be farther from the truth than if he had purposely striven to guess wrong, and not only wrong, but as far wrong as his most strenuous effort at imagination possibly could carry him. Silent as is the scene, lifeless as leagues of it appear, the quivering reeds screen thousands upon thousands of wild, free things, as yet almost ignorant of human methods and which spend lazy, dreamy weeks in fat content. The only magicians who can rouse these few folk are two: the one, a lath-lean, umber-visaged, shock-haired Breed; the other, one of those canvas-covered whites who seem to be everlastingly driven into the drowsy corners of creation.

The "silent, smoky savage" of a Breed seldom incites to riot. He hunts of necessity, and until he has had much to do with the white brother, seldom sees the sporting side. To him, cartridges 
are costly, and punting through reeds laborious; so when he does face the marsh, his chief idea is to get all the fowl he needs with the fewest shots and the least possible labor. Ignorant of town and town ways, he has mastered every mystery of the marsh for miles around; so when he silently launches his canoe and as silently steals along a channel to the reeds walling some pond, it is safe to wager that the pond is of easy access and more or less covered with drowsy ducks. In the art of the paddle, the Breed is only rivalled by those few white men who have devoted years to the study of the silent craft, while none has learned to excel him in that hazardous enterprise - the slow, soundless forcing of a canoe through dense cover within a few yards of the sensitive ears of a host of waterfowl.

There is, perhaps, no more difficult task in all gun-craft, yet the Breed can do it - remarkably well when punting a white man, perfectly when alone in his canoe. He never is in a hurry, and he drifts inch by inch like the shadow of a lazy cloud, till through the thinning reeds his wild eyes can distinguish the rafts of unconscious fowl. Those wonderful aboriginal eyes are swift as a modern camera. One flash of them takes in everything, especially the closest packed mass of the biggest and best ducks, for there frequently are several species floating in close proximity. Noiselessly as a lynx he discards the paddle and raises the cheap breech-loader. The muzzle steadies upon a bristle of unsuspecting heads, and the lead tears a long furrow halfway through the raft, as the gun is 
swiftly shifted for the second barrel. Then the canoe suddenly springs forward, for there are stunned and crippled ducks which may presently revive, and a clout from a paddle is much cheaper while quite as effective as another shot. If a goodly bunch of fowl be secured, the Breed may or may not repeat his deadly work a bit farther on after things have quieted down. He may paddle lazily homeward, but it is very pleasant in the canoe, and to hurry is a sin. The sun will not sink to the sky-rim for long hours yet, there is a rough lunch aboard, also pipe and tobacco, and the man who goes home too soon may find trouble in wading a trifle of poplar chopping, which is not for one moment to be compared with sun-basking in a grass-padded canoe as comfortable as a hammock. Besides, the swart-skinned wife really is putting on a shocking amount of flesh of late, and there is nothing better than some soulful swinging of an axe to reduce the female form divine. If the breeze be right, he may hear a whisper of remote chopping, and smile and snuggle down; for next to the roar of a gun and the wail of a fiddle, he most loves to hear the sound of sufficiently far-away honest labor. And this is the daily story of the Indian summer while the hosts of fowl, bred yet farther north, rest and fatten in the bounteous bay, while awaiting nature's final order for that marvellous flight to the lazy locked lagoons of a clime that knows not frost.

But occasionally there is another story. Near the rim of the bay stands the tiny log-shanty, its one wee window peering across desolation. On its outer wall are long rows of stout nails which no Breed 
would so sinfully waste, while within are upper and lower berths for four, and a low cot excellent for a man of all work. Heavy paper is tacked over the inside walls, there are nails to support all sorts of gear, and there are also a table, some benches, and a fine cook-stove and outfit. All this clearly is White Man's medicine, and burly indeed have been the patients of that prairie pharmacy. Upon the wall-paper are the pencilled scores of many a glorious day, and the tenderfoot surely would be puzzled by the names affixed thereto. The names, however, are no jokes; for Royalty, Statecraft, Bar, Pulpit, Art, and Science have all snored in those humble bunks, and pricked pleased ears at the hiss of the shaved bacon when the pink forefinger of Dawn plucked at the mist-curtain eastward.

Three old campaigners made short work of stowing the outfit in the wagons. Thompson, having been purchasing agent, attended to the checking off of various bags and boxes, leaving only handbags, guns, and raincoats for our attention. The Breed wagons were a three-seated spring rig and one of the ordinary farm type, and into the first went guns, shells, and a box of lunch. Then the other was carefully loaded and Thompson sung out: "All aboard, Batteese! But first shake hands with Mr. S- This is your punter, Ed, and a rare good un he is. The other chap's only a driver." Batteese solemnly shook my hand, but there was a twinkle in the wild eye which hinted that the observant rascal already had seen enough to reconcile him to the task of looking after the green one. As a rule, the punters are a bit jealous, each keen to 
ally himself with the best shot in a party, but a private hint from Thompson had not been lost upon the wily Batteese, who was well aware that his brother Alfred was Thompson's favorite, as an older man, an uncle, was Monroe's.

It was a great drive. Once fairly upon the trail, we rolled along almost as smoothly and silently as a billiard-ball. The entire region was one vast, level plain, seemingly an endless reach of alternate wild meadow and scrub, the only proof of progress being the approaching and passing of exactly alike areas of poplar. Thompson and Monroe literally burdened the seat behind the driver, while I had the rear seat to myself. This arrangement was, as Monroe claimed, "To let the wee chap have plenty of room for getting down and up before and after such chances as offered by the way." This also was very sarcastic, because I, the lightest and shortest of the trio, was sawed off at six feet one, and weigh about two hundred and 'steen pounds. The first ten miles were enlivened by an unbroken succession of yarns of the fur-trade, encounters with various animals, and not seldom of lively experiences along that very trail. But with all the nonsense and yarns, all hands kept a sharp lookout either side the way. Because Batteese knew his ponies as they knew the trail, there was nothing of actual driving, which left the swarthy one free to observe things on his own account. The superiority of the wild eye was demonstrated when brown hands suddenly hauled upon the reins and a voice like a low growl said, "Chicken dur," - the shock head at the same time nodding toward a clump of low brush 
some fifty yards away. "By George! he's right; out you go, little un. Walk straight for him and be ready, for he'll flush before you're halfway there," directed Monroe, and away I went. "Bet you a dozen cigars he misses," muttered Thompson, and "Done!" said Monroe.

A slight movement in the brush had told me exactly where to look, and I worried not at all. Three pairs of eyes were watching every movement, and above all I desired to favorably impress those microscopic black ones. A big sharp-tail rose at about twenty yards and went buzzing to the right, and I cut the head off it. "Ah!" said Monroe, as he saw it, and a few moments later Thompson muttered: "I think he meant it, but wait awhile. That's my gun he's got and mebbe she don't just fit." Another "solitary" was presently spied, flushed, and knocked down, but a something in its abrupt fall hinted of a "butted" wing. As feared, only a few mottled feathers marked the spot, but aid came from an unexpected quarter. "Me gettum - stan' dur - no move!" rumbled a deep voice, and Batteese slipped past and seemed fairly to glide over the grass toward some larger growth fully sixty yards off. At its edge he halted for many seconds, then suddenly flung himself with arms outstretched upon a tangle of dwarf stuff. When he got upon his feet a whirl of brown and white told the story. "Good eye, Batteese!" grunted Thompson, and we moved on. "If that had been a Bob White or a ruffed grouse," he continued, "even Batteese's searchlights might not have located it. He never saw a Bob White, but" (turning to the Breed) "s'posen' dat one birch par- 
tridge, you find um, hey?" "No-him los'," retorted the dusky one. "Him run - no find 'cept snow. Track den."

We had not travelled a mile before three pinnated grouse, coming from a distance, glanced on set wings across the trail, and pitched in some cover not more than waist high. This meant a royal chance, for in such shelter, especially just after a longish flight, the "chicken" is apt to lie very close. Unluckily they flushed together, so all I could do was tumble a brace. The quick flash of Batteese's snowy teeth told that the comparatively easy double had won him, and this was no unimportant matter, because it meant an enthusiastic instead of an indifferent punter when once we had got among the ducks. A brace of ruffed grouse, killed in the snappy, heavy-cover style learned in the forested East, completed the winning of Batteese; then we passed the last of the cover and rolled out upon the open plain.

"Dook - dur!" growled Batteese, after a while, and he pulled up. "All hands out and prepare for war," whispered Monroe; "there's a little slough beyond the rise just ahead. I'll go right, Thompson left, and you slip along the trail." I watched the big bent backs, and, when finally Monroe waved his hand, moved warily ahead. As I topped the rising ground, I saw some fifty yards below a small pond ringed with lush growths, at the edge of which the trail passed. Monroe and Thompson were skirmishing toward the common centre, and at the moment a big ripple showed on one side of the slough and a dark mass went into the cover. Nearer and nearer 
we all stole, then Monroe called out: "Ready! Don't drop any in the slough. Let 'em fly clear!" There was a breathless pause, then, with a bursting roar of wings, fifty or more big gray ducks sprang into the air and headed straight between my stand and Thompson's. A whole bunch passed so near that their every marking was visible and of these I tumbled four, three to the first barrel. Two quick reports, and it seemed to rain ducks over in Thompson's territory; then that worthy's voice rang out: "Quick! Watch Monroe!" A lone pair of fowl had turned and was rushing high over the third gun. Up straightened the tall figure, two barrels sounded in swift succession, and duck after duck folded up like a brown parcel and came hissing down to strike the grass with an earnest whop! whop! such as only extremely dead fowl make. And from Thompsonville-in-the-grass arose a sounding a-ah! of admiration, for 'twas a noble double and the temporary mayor of Thompsonville, etc., was above any petty jealousy. He had the most ducks, but none knew better than he the difference between flocking a near-by bunch and pulling down such a brace of climbers.

"Thought you had me out in the cold, eh, you rascals? but I did get a crack, after all. Oh! I'll learn yet. My, they're a fine lot!" The hearty ring in Monroe's voice was good to hear, and I expressed unqualified admiration of the prettiest lot of gun-work seen in many a day. But the real worshipper was standing like a bronze statue in the wagon. Black eyes had noted every move of that brief skirmish, and they flashed with joy as Monroe 


\section{Picked from the Prairie Province}

sung out: "Batteese! You see dem try rob me of my chance? Mean trick dat dey do, hey?" But all Batteese said was, "Good-my-brudder!"

That ended the sport for the time, and at last we caught the flash of distant open water, near which was what looked like a doll's house, or some crumb of civilization dropped from a balloon. Breed bands had cut the rough materials miles away, then put them together under Thompson's directions, while the door, window, and dressed boards for inside work had been shipped from Winnipeg and hauled the final stage. As I soon learned, it was a mighty snug shack. The long rows of nails upon the north wall suggested that somebody had prepared for great numbers of duck, but the south side was more interesting because it supported a rough lean-to under which lay a big skiff and two fine cedar canoes. Inside each craft were stowed two light paddles, a long punting-paddle, and a dozen hollow decoys. There is no danger in leaving things that way. The natives never meddle. If one happened along, he possibly might borrow a few decoys, a paddle, or even a canoe, but everything used would be carefully replaced, while word of such using would be sent the owner at the first opportunity.

When the stuff had been unloaded and properly stored, Batteese made a fire and prepared bacon, eggs, bread, and tea for all hands. The ponies were watered, hobbled, and allowed to graze, and the boats were lifted from their shelter and carefully examined. They proved to be in perfect condition. The huge punt was a queer craft. "She's my tradingschooner," said Thompson, laughingly. "When I 
shoot ducks, I like to feel both safe and comfortable - so there you are!" Monroe winked, for, like myself, he is a stanch lover of the cedar canoe, of which he is undeniably a master. The trading-schooner was Thompson's (not the punter's, you understand!) idea of what a ducking-craft should be. Not so very long and low, but of tremendous beam, it floated with a raft-like steadiness. About midships was a great revolving chair, in which the mighty captain was wont to sit in plethoric ease and administer to the ills of such fowl as evinced any need of a tonic with lead in it. Meanwhile, the unfortunate punter just punted for all he was worth; and when he got back with a choice lot of ducks, as he invariably did, he mostly slumbered till the next starting-time.

When the craft has been carried to the water and equipped with grass and decoys, the punters departed for their near-by but hidden village, with the understanding they would return at gray dawn. As the wagons started Thompson bawled after them: "If you meet that frog-eating artist, tell him to hustle out here! We're not going to do our own cooking!" He explained that a young Frenchman, an expert at camp cookery, would arrive sometime before sundown, and that the probable reason for his tardiness had been a dance somewhere the previous night, an attraction which no Breed nor French Canadian could resist. "He's a nice fellow, is Jean; I've had him with me many times and have yet to see a better hand at a cook stove. Now, we'll get plenty of ducks to-morrow in the marsh yonder; suppose you and I do a trifle of skirmishing afoot. There's a few miles of wet ground below there, and 


\section{Picked from the Prairie Province}

we'll surely see plover and perhaps a few snipe. Let's get on the waders and fill up time, anyway."

Monroe was hanging shooting togs upon the nails which each was to consider as his own, but he had changed from tweed to sweater, cords, and waders. "You fellows go ahead, and I'll try later; the ground's not broad enough for three abreast," he said, and Thompson bowed in mock gravity and replied, "Thanks, $\mathrm{O}$ most gracious monarch of the marsh ; thy insignificant subjects be most truly grateful." I felt there was something behind this peculiar speech, and as we tramped toward the good ground, I asked what was the joke. "Joke!" exclaimed Thompson; "there's no joke about it! But I forgot you'd never seen that long-legged old pirate talking to small game. Gad! if he's a joke, I'd hate to be a snipe when a fellow in dead earnest happened along. He's as fast as a bullet when he wants to be, and those big lamps of his can see behind like a rabbit. You just wait awhile and you'll see something worth watching." The veteran, in spite of his firm belief in Monroe's superiority, was himself a rare good shot, as I presently discovered when we reached a few acres of the blackest of mud. From a tussock of grass sprang a swift, brown thing, its bent wings making a "Whip-ip-ip!" of hollow sound, its alarm cry, a rasping "Sca-ip! — scape!" as it darted off in the typical series of twists and short zigzags. Instantly Thompson's gun cracked, and the wavering flicker of brown changed to a point of white as the bird turned over and struck the mud. "Whip-ip! Sca-ip!" twice repeated, and I folded up one and sent the other to the mud, to bounce again 
and again as the cut wing refused to perform. The last bounce carried the snipe into a pool, across which it swam smartly, then ran into the grass, where I presently found it. Then we proceeded to enjoy one of those bits of flawless snipe-shooting which reward Northern Nimrods who chance upon good ground at the proper times. Thompson kept cutting down his birds in a fashion which suggested an entire ignorance of the art of missing, while I hammered away, the keener and quicker because I knew what the end would be, but was bound to make an even race of it as long as possible.

Not seldom three and four birds flushed in rapid succession, those unshot at sweeping back to the ground first covered, which guaranteed plenty of sport for the return. At a point some half a mile away from the start, Thompson halted and pushed back his cord cap. "Guess we're far enough for the first trial ; this mud's no joke to a heavyweight," he panted. "How many have you? I've got twentyfour." In my coat lay nineteen, and I feel free to say that the united straight string meant rare good work by two men. Needless to say it was not to be expected upon many days, for no man has a license to average more than three-fourths of even his favorite birds the season through. I always count my shells, because I want to know exactly how I am shooting, and it's simply wonderful the way a fellow will forget a miss here and there unless he has some sort of check on his work. Old sportsmen are too wise to worry over misses; in fact they don't care anything about them, but they do like to know their true form each day. It's astonishing 
how many careful men will get astray when describing their shooting, but they only deceive themselves when they tell of too long strings without a reasonable number of misses.

"Hullo!" said Thompson, "yonder comes old snuff-'em-out over our ground. Now watch him and you'll see what crack snipe form looks like." At the home end of the ground a tall, erect figure was steadily moving toward us. It suddenly halted, and almost instantly we heard a quick crack-crack! as though both barrels had been fired at a single bird. The distance was too great for details, but Thompson said, "Watch him gather." The figure resumed its march, only to halt, stoop, move on a few yards, and again stoop. "Good!" grunted Thompson. Five times the advancing gun stopped single birds, and presently its bearer was near enough for the watchers to distinguish every movement. "Now, look out. I think there's two birds right in front of him, and if he happens to get between 'em, you'll see why I just dote on his style. Ha!" The cause of the sudden exclamation was the flushing of a brace, - one bird darting due east and the other as truly west, and both going like all possessed. Crack! and the right-hand bird spun end over end. Crack! and the second spread its wings stiffly and slanted down, a glint of white showing where it turned over on the mud. "That's the way! Good old eye!" roared the delighted Thompson; then quickly added, "Now, watch him retrieve." Monroe, loading as he went, walked straight to the last bird and picked it up. Then he back-tracked to the firing-point, faced to the right, and walked as 
directly to the second snipe. "It's a good way, too," continued Thompson; "he knew that last bird might be lying back upward, and be hard to see, so he never took his eyes off it. Had either seemed to be not clean killed, he would have gathered that one first, because a wounded bird is apt to run a little and hide. So soon as he got back to his empty shells, it was easy to stand a moment and get a true line upon the whereabouts of the first bird."

"Well, you didn't kill 'em all, I found," chuckled Monroe, as he joined us. As we neared the house, a figure in shirt-sleeves showed, and the smoke rising straight above the roof told that Jean had arrived and got busy. Two hours later we pushed back our chairs and I remarked: "This is great! Jean's the greatest killer, unless we get muzzles."

"Now for a pipe, and then to bed," said Thompson. "The boys will be here before daylight, and we must be into that marsh early. You'll have everything ready for us, Jean?" The cook grinned and nodded assent. He could cook a heap better than he could talk, and he well knew what one of Thompson's early starts meant. He would silently prepare breakfast, put up three big parcels of lunch, see his people started, set the house in order, then put on somebody's boots, fill his pockets with shells, take his old, cheap gun, and away to the wet ground. Not for snipe - "Heem too small, an' heem fly too fass, dat small beccasine-yes! But zee plovaire-yes! Heem go slow - beeg flockbrum-brum! Oh! yes."

As we pulled at the pipes, there was a most interesting chat about snipe. According to Monroe, the 
dodging flight was merely a peculiarity, and not what many writers have claimed, i.e. a crafty scheme on the bird's part to baffle the gun. In the brave days of old when such small birds were deemed not worth pursuit by our meat-hunting ancestors, the snipe dodged as he does to-day. Then such a thing as a firearm had not been dreamed of, yet the bent-winged dodger scaped and twisted, which proves that whatever the cause of the peculiar flight, it was not to baffle the aim of a gunner, or even a man using any form of sporting appliance. Before the invention of gunpowder, game was trapped, and the larger kinds slain with the bow and arrow, some form of crossbow, or by spear, or other contrivance, held or hurled by the hand. A wee fellow like the snipe had naught to fear, except, possibly, some form of trap or net, so there was nothing to foster the development of the dodging flight. Nor does it seem reasonable to suppose the quick spring and twisting movements were intended to confuse some furred or feathered foe, because several other birds, more or less closely related to the snipe, haunted the same ground and were exposed to the same perils, yet their descendants of to-day show no trace of the alleged artifice. We all are keen observers and ardent admirers of our beautiful game creatures, but we place no faith in those too common writings in which some dreamy but only half-informed pen-jugglers cause the lower creatures to reason and converse like human beings and equal the brain-efforts of highly intelligent men.

The snipe dodges because he is built that way, 
and cannot help it. Something, perhaps, in the relative proportions of the very long bill, the wing, and body, or in the shape of the wing, or, what is more probable, in a peculiarity of the wing-stroke, causes the light body to shift irregularly in the act of attaining high speed. To credit the snipe with an intelligence capable of wing-manœuvres intended to puzzle a man is absurd. Probably one-half, or more, of the snipe killed were crossing, or at such an angle to the line of fire that the twisting helped not at all. Birds that knew enough to play tricks might reasonably be expected to also know enough to play them in the only direction in which they were worth playing. Many a snipe has dodged out of the line and back just in time to catch the full charge. The fact is, a snipe, upon a calm day, is apt to fly in any direction, but in a breeze the favorite route appears to be up-wind. A properly educated snipe-shooter knows this, and unless he be one of those who prefer the more or less straightaway shot, he works down-wind, which means that birds rising before him and trying to fly up-wind must pass at either side, and offer a chance in which the dodging ceases to be a factor. And there is more than the outwitting of the dodging in the down-wind work. The cross-section of a snipe going straight-away is not bigger than a silver dollar; the rather long wings, too, are then edge-on to the gun, while the vulnerable head and neck are more or less protected by the body. These conditions are apt to mean wounded instead of instantly killed or winged birds. On the other hand, a crossing snipe needs must expose one entire side and 
something of the second wing, which would mean, roughly speaking, a mark as large as one's hand instead of the size of a dollar. It is less cruel, too, for the simple reason that the easier the chances, the greater the probability of exact shooting, which means instantaneous and painless death.

The session was closed by a mighty snort and the clatter of Thompson's pipe upon the floor. He had dozed but ten seconds, but, as he said, he knew the sign. "Last man dowses the glim," he yawned; " upper four for yours." And in very few minutes a sound not unlike distant surf told that two big fellows had got away to a remarkably even start. I climbed up and stretched in luxurious ease in the folds of a huge gray blanket which covered a sureenough hair mattress. Not in the least sleepy, I lay with closed eyes studying mental pictures of broad wetlands, above which springy, bent-winged sprites wove mazy problems for up-wind shooters to unravel. I had just about made up my mind to doze off when something hauled at the blanket and a voice roared, "Tumble down, you snoring lubber!" Very much astonished, but gloriously rested, I followed directions, which led out into a dim gray world and finally to a tin washdish. Half an hour later we moved to the waterside, where the punters were waiting. "Off you go, and good luck to you. Be careful; there's no bottom anywhere in the marsh," said Thompson, and in a moment my canoe slid into open water and headed north. As it rounded the first bend of the channel-like open, the battleship steamed straight into the reeds, while the second canoe started south. 
"Load - duck - soon," rumbled Batteese, and I glanced through the barrels, loaded, and knelt comfortably, awaiting developments. Soon a quick double-shot sounded from one side, and a long string of fowl came speeding across the course. "Red-head - shoot!" muttered Batteese, and one dropped at longish range and was boated. As we rounded a bend some hundred yards farther on, Batteese whispered, "Can-vas-back-dur," and I saw about twenty big fellows floating near the wall of reeds. No mistaking the peculiar wooden appearance of the long heads and proportionally long necks, the latter stiffly erect and the heads looking as though they had been stuck on at right angles to their supports. With a quick roar of wings the fowl sprang straight up several feet above the water. It was a fair chance, and a bird fell to each barrel; but alas! the second duck at once went under, the other shifting about in erratic circles. This one Batteese at once secured, and forever ended its kicking by nipping its neck between his teeth - the most persuasive argument to reduce a duck to inactivity. No effort was made to find the other. "Canvas - back - dive - no - good - look," was all the satisfaction I got. The Breed's shrewd eyes had noted the tipped wing, and he well knew how useless would have been a search in such a place for the master-diver of all our choice duck.

"Teal-dur," he presently warned, and I saw a dainty wee green-wing standing close by on some drifted reeds. That bantam surely had electric flying-gear. It sprang like a ruffed grouse, and through a double puff of haze "vainly the fowler's 
eye" did mark a receding speck rather suggestive of an extremely busy bee. I could not resist a peep astern, and lo! Batteese's noble grinders were displayed from end to end. "Teal-fass - look bluebill-quick!" And straight ahead streamed a grand flock of fully one hundred of the squarebuilt, lively fowl which so greatly add to the sport of the larger marshes. Three or four hit the open water, others crashed into the reeds. "Quick! shoot - crippul — " warned Batteese, and I knocked over a duck which showed signs of a partial recovery. To pick up the floaters was a simple matter, then I got a touch of the Breed's real quality. Straight at the wall-like mass of reeds went the canoe, and when she had been forced by main strength twenty feet into the cover, he said, "Dook -dur!" and under my hand was the chunky, floating form of a nice drake. Then out crawled the canoe, only to butt into the growth again and again at various points till five more fowl were boated. And not once did I see a feather, until the laconic "Dook - dur!" caused me to look straight down and see the floater within easy reach. The last time he worked far in, peering from side to side and parting the reeds with his paddle. "Woun - dud," he grunted, but the next moment his paddle sung through the air and almost decapitated the duck, which was trying to slip abaft of the canoe and some few inches below the surface. The craft was now firmly wedged, but he had an easier method than poling. Moving midships, he seized a handful of reeds and pulled, and we slid several feet, after which a few more pulls nearly cleared the cover; 
then he went to his place and backed out with the paddle.

"Put — decoy — dur," he remarked as we neared a long point of reeds, and soon the dozen lures were riding to their weighted cords. Then the canoe was forced her length into the reeds, a bunch of the tough stems was tightly twisted round the middle thwart at either side, and the late sensitive craft was as steady as a floor. "Bess - stan up - no - fall - deep - dur," he instructed; then we changed places, and I could stand at ease with eyes just above the cover. The picture was most interesting. Immediately in front was the open channel with the decoys shifting and nodding to the breeze in a most lifelike manner. Forty yards away, another wall of reeds, and beyond that a brown, quivering level of foliage which seemed to extend to the horizon, and above the brown, in half-a-dozen directions, streamed swift fowl in long flocks, small groups, and pairs, while every few minutes sounded a dull rump! - rump! which told that Thompson and Monroe were having a lively time somewhere in the sunlit waste.

"Blue - bill!" grunted Batteese, and there was a hollow humming, and a single duck "cut down" in the beautiful method of a bluebill stooping from a great height to decoys. It struck the water with a spat and bounced with cork-like buoyancy. Batteese gave it one glance and grunted, "Dead." In a moment he added, "Crow - dook," and I saw a line of very large foul heading straight for the point. Cormorants being fishier than a political deal, the sable array was allowed to sweep past upon their fry-destroying mission. 
Bluebills in flocks of all sizes, and, at irregular intervals, redheads, came whizzing along to hover above the decoys and receive a double salute, and as I realized that there were unlimited numbers of fowl, I began a selection process in which only rather difficult shots counted. Even then, I had about all I could attend to. "More — shell," remarked Batteese, as he passed a second box of twenty-five. "Plaintee - more," he explained as he proceeded to tear open a third box of the half-dozen beside him. He knew that the main flight was yet to come, and that three hundred shells were none too many for a typical day. His wild blood craved slaughter, and if ten thousand fowl could be killed, so much the better. But I have notions of my own on that question.

Certainly there was plenty of variety. Now it was bluebill, then redhead, then, with a hollow roar, a dozen swift canvasbacks; then the measured winnowing of a pair of mallard, the steamy hiss of the teal's bullet flight; the sounding hum of shovellers; and through it all the silent black-and-white flickering action of pretty little huffle-heads and mergansers. And there was so much of it that before noon I was both ready to eat and to stop shooting for the day. So the gun was laid aside and we dawdled over the food, heedless of the rushing wings audible every few minutes.

"You go home?" he blurted out, in his astonishment for once speaking rapidly, and I nodded. He said never a word, but his face appeared to take on a darker shade. The canoe was freed from her reedy tethers, the decoys were lifted, and he began his quest 
for the fallen. "How many you make it?" I ventured. "Fifty-fo'," he growled, and something in the way he said it hinted that about five hundred and four would have better suited his taste. Then followed the finest exhibition of gathering that I have seen. "Fifty-fo'," he had said, and "fifty-fo" " it had to be, or there would be a raking of that marsh by the fine-tooth-comb process. About half the ducks had fallen into the reeds, and I had but a vague idea of where any of them lay. Strung along for one hundred yards of the open channel were white and dark forms slowly drifting with the breeze, but to these he paid no immediate attention. Instead, he paddled up-wind to a certain point, drove the canoe into the cover, and said, "Bluebill — dur," and touching the side was the duck. Out went the canoe, then in again some dozen yards below, straight to another fowl. Then I grasped the fact that he had gone to the most distant victim, and proposed to drift back and gather the others in turn. It was a puzzle how he could remember the exact location of each one, especially on the back trip, which meant an entirely different point of view. Yet not once was he astray, although one duck was not secured. "Tink — woun - dud," he muttered as he drove the canoe far in and parted the reeds just ahead. "Gray - dook - los' - dive - dur," and he pointed at a slight movement in the water, and then the canoe was hauled out. The boating of the floaters was easy, and lo! the last made the count fifty-three.

"Batteese, you're a wonder!" I exclaimed; "I haven't the slightest idea how you do it, but I've 
just seen it done, and that's enough for me." The beady eyes twinkled, and the white teeth showed as their owner slowly rumbled, "We - go - home nudder - way - find - dook — in - pond." Only intense satisfaction could have released this torrent of eloquence, which actually startled me. And what followed seemed even more wonderful than all previous performances, for he laid a straight course for the invisible shanty, heedless of what lay in the way. Compared with tracing even erratic channels, it was something like riding across country instead of following well-defined lanes, and more than once I felt a trifle dubious concerning the issue. But there was a method in his seeming madness. Right well that wily rascal knew that between where we were and the shanty lay several hidden ponds, his own favorite potting places. Not for a lot would he have revealed them to either Monroe or Thompson, to whom he would have declared the route impracticable on account of weight, which, while false, would have sounded all right in the ears of experts who understood what extra weight means in a marsh. The simple fact was Batteese wanted more ducks, and while apparently humoring my desire to avoid too much killing, he really was leading me into temptation.

"Beeg - dook - dur - keep - still," he whispered, and I thought I might as well be ready. Straight into the breeze to which the reeds were whispering crept the canoe, and a something in its wary movements warned that it was no ordinary quest, yet we stole on and on for full fifty yards. Then on the breeze came a murmur of peculiar 
sound, a droning of many duck voices, blent with the fluttering of many wings and the squattering of feeding fowl. My heart thrilled, for I knew that a mighty host of web-footed merry-makers was concealed just ahead. A moment later the cover in front suddenly thinned, and I came near yelling with astonishment. About an acre of open space seemed to be covered with a live and exceedingly downy quilt of a most amazing pattern, and its nearest edge was not ten yards away. Perhaps nowhere else in the world could such a picture of wild life be seen, but the view was brief. "Me-ak!" shouted one horrified fowl, and erstwhile careless heads bristled up in every direction like so much stubble. Then with a roar worthy of a lightning express, the feathered host sprang into the air in such close order that the sharp biff-baff of clashing wings was distinctly audible. For a moment it looked as if the entire pond had gone up, but Batteese's gasping "Shoot - shoot!" caused me to remember the excuse for the intrusion. "Shoot!" almost prayed Batteese, and as the feathered canopy ripped apart and left one great drake exactly in the centre of the tear, the first barrel did its work on the single. And of all that storm of life the second shot stopped but three, and one of those happened to fly into it fifty yards away. And poor Batteese, to say the least, "Heem - ver - sad," as the way he drove that canoe through the reeds rather suggested. No more clever work for him that day. What he wanted was to get home and smoke and ponder upon the bitterness of his lot which condemned him to daily association with a duffer who 
didn't know enough to wreck a raft of ducks when it floated within easy range.

At the shanty he sulked till evening brought the others home. Then again his wonderful eyes sparkled and his white teeth flashed, for, after all, his foolish if not actually crazy white man was not "low boat." And to brother Alfred did Batteese confide: "Heem - one-funny - man, — dat - beeg - fel-low. He - shoot - all - right, - but - heem - too - scare - to - kill - dem - much."

"They seem a great lot," said Thompson, as the last pair was tied and added to the rows upon the wall, "but you see it's this way. We have many friends who seldom taste game unless we give it to them, so when we come here, we shoot for the crowd at home as well. If we killed a thousand fowl, not one would be wasted. Now that we've made so good a start, we'll hold our hands a bit." And this was done, and day by day the bag decreased, until finally only canvasbacks, redheads, and gray ducks were shot. At last came a peculiar, gray morning, which meant "Break Camp." All through the previous afternoon long strings of fowl had risen high and streamed away due south; so word was sent in for the wagons. The southbound ducks proved true prophets; for as the last of the outfit was taken aboard the train, a sudden squall and a horizontal rush of blinding sleet told that the white wolf of the north was afoot for a southerly raid and would be howling at top speed ere the dawning. 


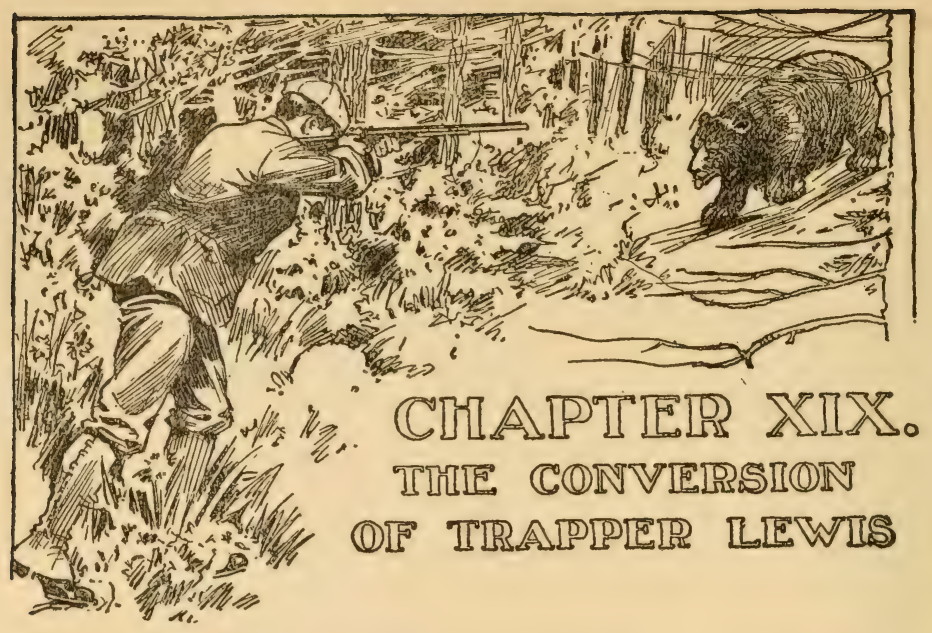

HE was mighty hard to convert. As he put it himself, he was "sorter sot in his ways," and above all, he "didn't keer fur no durn boys to be foolin' round him." I doubt if evangelist ever softened a tougher subject.

I was then a big, raw-boned lad, a fairly good shot for my years, and crazy to get hold of all possible information about shooting and trapping. I had to stay with an elder brother in the woods till his lumbering operations could be concluded in the following spring, which meant that I had at least ten months during which I could fish, shoot, and trap, according to season. It was a fine opportunity, for there was plenty of game, large and small, within rifle-shot of the wretched village which consisted of a foot-path, with a saloon and a couple of dozen other buildings strung along it. At least half of the male residents hunted or trapped at odd times, but they didn't amount to much. Several of them used to find pleasure in stuffing me full of yarns of 
their experiences, but they were merely picturesque old liars. The real trapper and hunter, the man who had trailed across the continent, and who knew the secrets of woodcraft, was Lewis. He had mined, prospected, trapped, and hunted in the far west and north for at least forty years, and I pined to know him and gain his confidence. Many attempts had failed, many drinks had been uselessly paid for. I had tackled him every way I could think of, yet all I had received in return had been an occasional "Hello, Canady," when he chanced to be feeling particularly genial, and perhaps a few muttered remarks when he agreed to swallow drinks at my expense.

Lewis was not much to look at. He was short, thin, and did not weigh more than one hundred and thirty pounds. His face was brown as a mink pelt, much wrinkled, and marked with a ghastly white scar obtained years before in a set-to with a wounded grizzly. Hair, stubby beard, and eyebrows of yellowish white contrasted curiously with his dark skin and beady eyes. Taken all in all he reminded me of an ancient monkey. Despite his habitual lounging walk and battered exterior he was full of vigor, and quick as a cat if occasion demanded. His gait in the woods, or on a trail, was not so very fast, but he could apparently stay forever, and, as I found out later, he had a peculiar knack of wriggling through rough places which would baffle many larger and more powerful men. His favorite weapon was a double, muzzle-loading rifle of the old-fashioned "over-and-under" pattern, and with this rifle, or with any large revolver, he could do some cracking good 
shooting. With the shotgun he could do littlehe wouldn't try it, for he hated that weapon with all the unreasonable pertinacity of the old school of still-hunters.

"Them durn noisy things won't kill nuthin'!" was his contemptuous remark the first time he saw my expensive fourteen-gauge muzzle-loader.

This was the kind of man I had undertaken to thaw out, and my scheming for two months had affected his bearing about as much as a New York bonfire would affect the Polar ice-cap. He once had so far relented as to say to a friend of mine: "Canady's a slick-spoken feller 'bout huntin', an' a mannersome feller, too; but I reckon it's all book larnin' an' don't amount to much ennyhow. I'd like to see Canady run foul of a bear - his durn slick talk wouldn't help him enny, an' I reckon his shootin' 'd be about level with his talk."

Beyond this unsatisfactory state of mind he had showed no symptoms of ever advancing, when the first of three events, which marked three stages of what finally became a warm friendship, occurred.

The lounging-place of the village was, of course, the saloon. It had a long room with a bar across one end, a pool table in the centre, and a dozen rough chairs strung along the walls. The pool table happened to be a new one, and at that time I was supposed to be a good player.

One evening I strolled down to the saloon and found Lewis and half-a-dozen of the regular hangers-on sitting swapping yarns and possibly (?) waiting for somebody to stand treat. I filled the long-felt want, then I picked up a cue, and began knocking 
the balls about. I had no intention of playing, so paid no heed to where object or cue-ball rolled. The crowd watched me lazily for perhaps ten minutes; then, to my astonishment, Lewis remarked: "Say, Canady, I reckon I know a feller can down you at that game - fur a dollar!"

A thought occurred to me that perhaps I could get solid with Lewis at last, so I quietly weighed the chances for a time and decided to take them.

"So you think your man can beat me, Mr. Lewis?"

"That's what I said, Canady."

"And you're sure he can do it?"

"Shure! I know he kin! If he don't, he ain't no son of mine."

"Oh, he's your son, eh?"

"That's what I said."

"Well, when do you want to try?"

"Will you go him, Canady? By gosh! we'll just play you right now. I'll fetch him, - he ain't far off, you bet! But hold on thar, Canady! Just pile up the dust 'fore I go after him. Don't want to fetch no feller fur nothing, understand!"

We put up our dollars for a match, best three in five games, and the old chap started after his hopeful progeny. I don't think he had far to go, as I suspect the son was just outside the door, and the whole affair was a put-up job. Anyway, they soon appeared, accompanied by all available citizens. The old man evidently considered the contest an international affair, the stakes immense, and the coming triumph of his son too important to be missed by any one. 
The crowd took up easy positions around the table, and the game began. I presently wished myself well out of it, for I soon discovered that my opponent was a very ordinary player and was also badly rattled. Luckily he had never seen me play, and it would have been a simple matter to have let him win. This I had figured out to be the shortest cut to Lewis' friendship, and I intended trying it. But an unexpected complication arose. One of the few friends I had in the place sung out, "One dollar that Canady wins the match!" This was a muddle! I could not fool my friend out of his money, yet if I beat young Lewis, - farewell to all hope of further association with his redoubtable dad. Finally I begged off on the score that the betting made me nervous, while my friend took alarm from a timely wink and agreed to shut up. After some intentionally poor play, Lewis, Jr., won the first and second games. As we began the third frame my would-be backer edged near me and whispered"What in thunder are you tryin' to do? They won't play no higher!" I could have roared with laughter at the idea of that game, for the entire outfit couldn't have scared up ten dollars. Lewis, Jr., won the decisive game, much to his delight. But 'twas his dad who derived the real satisfaction. from the winning.

"Gimme them thar stakes! Gimme Canady's dollar," he shouted, and in the fulness of his joy he actually treated all hands. For once he became talkative, and made divers sneering references to Canada and all things Canadian.

I felt a trifle savage, for I saw that I had made a 
mistake. Had I won the old man might have been mad, but I should not have earned his contempt. Therefore, I was not at all sorry when some sharp talk arose between my friend and a man who had wanted to back my opponent.

Old Lewis was keen for another match, but I called him aside and asked him as a favor to sit still and watch the game if we played another.

$\mathrm{He}$ at once became suspicious, but agreed to do as I asked. Meanwhile, the disputants had arranged another match, for a dollar a side, young Lewis to play and stand to win, or lose, nothing. This arrangement gave him confidence, and he rashly broke the balls. I found an easy set-up and pocketed fifteen straight. After a moment's silence the crowd voiced a hearty "Good boy, Canady!" and before the man who had lost the dollar had time to get real mad, I had made the bettors draw their money.

Things turned out better than I had expected. The crowd agreed that "Canady was a square feller," and old Lewis held out a paw and said: "Put her thar, Canady; yer a cuss to play pool; but what'n thunder did yer throw off in the first game fur?"

"Just for a bit of fun," I replied, for the last thing I wanted him to know was the true reason. From that day on Lewis and I became almost friendly, but, while he would speak of his old-time experiences in the West, I was unable to edge him in the direction of his more recent doings. In fact, I believe he thought I was a well-meaning youngster and a confounded nuisance to boot. Anyway, 
he showed no disposition to ask me to join him for a hunt until the season was well advanced. I could laugh now as I think of the times when I accidentally met him on the road near the village; how I'd pretend not to see him, and would toss up a small stone and rattle a load of shot against it before it fell, and how at last I killed a flying pigeon at long range - longer range than Lewis had credited to the despised shot-gun. That time he stopped and said: "Canady, I reckon yer pretty handy with that scatter-gun, if that pigeon wasn't killed by accident. Wish I could run you up agin' a drove of pa'tridge - they'd fool you, fur yer can't hit them fellers when they're goin' in arnist."

This was said in such a decided tone that I almost laughed. I told him that "pa'tridges" were easy enough sometimes, and to my delight he exclaimed: "Is that so! Well, I'll show you they ain't; I just passed a drove of 'em a piece back, an' if yer game to go, I'll take you to 'em, and see how you shoot."

Lewis's "pa'tridge" were ruffed grouse, and we soon found the brood in some briers. When they rose in the open, I managed to kill with each barrel. The first bird was the old hen, and the fact of the second being a slow young one made the right-andleft easy. Lewis was thunderstruck, and his surprise was heightened when he saw the old bird. But in a moment his prejudice reasserted itself, and he remarked:

"Slick work, Canady - yer a hummer; but did you hear how she roared through the timber? That durn gun's too noisy - she'd scare every- 
thing out of the woods! An' she ain't no good fur anything bigger'n pa'tridge."

However, old Lewis had been somewhat impressed. He spoke of the grouse in the village, and I heard that his comments upon the first wing-shooting he had seen were quite favorable. Still the longed-for comradeship did not arrive, although the thin end of the needful wedge had been inserted in the old fellow's cross-grained notions. His final capitulation came about in this wise :-

One day I felt lonesome, and decided that a tramp along the railroad would be good medicine. I did not expect to do much shooting, but pipe and gun are always good company, so I took both with me. As I was in a wild country, a couple of balls to fit the gun and a charge of buckshot were in the pocket of the shooting-coat. I knew that the railroad ran through a burnt district famous for pigeons and berries, and decided to go that far and bag a bird or two, if nothing more. Before I reached the "burn," I saw old Lewis, with rifle on shoulder, emerge from some cover and cross the track ahead of me. He was evidently trailing something, and in a moment he saw me and beckoned.

When I reached him, he said - "Look thar, Canady; what you think of that fur a track?" I saw an impression in the dust, and asked if it was not bear sign.

"Just so, Canady; 'tain't nuthin' else-look a-yonder where he crossed the creek."

Sure enough, the moist sand bore unmistakable imprints. 
"Now, Canady," the old man went on, "if yer good fur a whirl with him, I don't care if you come along. He's workin' to the berry patches." I at once drew the charges of shot, and put an ounce ball in one barrel and nine buckshot in the other. Lewis looked on with interest, and upon my telling him that the fourteen-gauge would shoot ball first-rate, he exclaimed - "Well, I hope she do; fur, by gum, she may have to 'fore you get through."

We agreed to take opposite sides of the creek, which was full of floating logs that had missed the freshet, and were waiting higher water. Lewis's parting advice was - "Go slow; yer not apt to see him till you reach the berry patch. Don't try no fool shootin', and don't let that fool-gun get you into trouble."

I fancy that Lewis knew too much about black bear to really anticipate any serious trouble, but I also knew that his advice was good, and determined to act upon it. We parted, Lewis following the tracks across the creek, while I moved ahead, keeping what I judged to be about abreast of my comrade. The cover was dense, and the course of the creek very erratic, which fact made it as likely as not that the bear would finally be found upon my side of the water.

After a lot of slow, cautious work I drew near to the berry patches. No sign of the game as yet, but I presently discovered a footprint in a muddy spot. It had been made by the bear, and so recently that the muddy water was still slowly trickling into it. So the brute had crossed to my side! My first thought as I viewed the sign was, Won't old Lewis 
be hot! and for a moment a feeling of triumph overcame every other sensation. He'll sneer at Canady, will he? Guess I'll show him - show him - what?

The triumphant feeling fizzled out, and in its stead arose a sensation of utter loneliness. A second glance at the track detected a number of little holes in the mud. Claws had left those traces, and a series of sickly tremors crept up my spine as I peered nervously into the surrounding cover. At last I moved forward, but halted before I had covered thirty yards. What was the outrageous thumping in my chest, as though some imprisoned thing were trying to beat its way out? I knew what it was, but I could not stop it. Did I really want to kill the bear-had it ever, by word or deed, injured me? I felt that it had not. Why then was I so keen to slay the poor creature - why was I there at all?

I began to wish myself well out of it. Why hadn't the fool bear stuck to the other side of the creek? Lewis was a bear hunter, and the proper man for the animal to interview. Were there two bears? If there were, this one wasn't the bear I was after. Old Lewis was after my bear. I had nothing against this one; in fact, it wasn't the bear at all! Besides, mebbe the old man was right when he said that a shot-gun was no good for bear. I came precious near going over to see old Lewis about it!

I figured out that mebbe if I broke a stick or two, or made a little noise, this bear would sneak away and I could go on and slay the right one. Finally, 
the uncertainty became unbearable, and I crept doubtfully forward for half-a-dozen steps, then shrivelled into as near nothingness behind a tree as a man can, for straight ahead, about fifty yards away, was the bear! It had not seen me, and, luckily, it was moving from me, else I'm afraid I'd have stampeded.

Its black body disappeared behind some cover, and as it vanished my feeling underwent an extraordinary change. A fever of excitement, a wild impulse to follow, seized me, and I stole forward as rapidly as possible. My loss of nervousness, and the new, keen desire to kill, astonished me. The sight of the game had braced me up. The previous long, uncertain stalk had rattled me, but things were now all right. "Shot-guns no good" be hanged, and old Lewis, too! The fourteen-gauge should prove its merit right now.

Crack! crack! the double report of Lewis's rifle ripped the silence of the woods. I leaped upon a $\log$ and saw the old man skip behind a tree. I saw his arm flourishing as he strove to reload; then something black rolled into view about halfway between us. The black thing finally got upon its feet and came blundering directly toward me. I glared at it for a few seconds, then tossed up the gun, and fired both barrels when it was hardly twenty yards away. It collapsed, for the ounce ball happened to find the head.

Up came old Lewis on the jump. He took one look at the bear's head, then excitedly exclaimed, "Great gosh!"

"What's wrong?" 


\section{The Conversion of Trapper Lewis}

"Why, Canady, I'll be eternally chawed up! Why didn't you blow the hull head off the durned fool, while you was at it? By gosh, that scatter-gun shoots some! See whar the buckshot ketched 'im; the big ball knocked the brains clar out. But, Canady, I drawed true on him; I bust his shoulder, t'other ball cut his leg. I knowed it would, fur it grazed a sapling."

So I had managed to knock down a dying bear, and to fill it so full of missiles that its hide might have served as a title-deed to a lead mine. I didn't care if I had - we'd killed the bear!

The animal was not nearly so large as I had expected. I waived all share of the quarry and the bounty, if there was one. Lewis got out his knife and gave me an object-lesson in the matter of how to flay and carve a dead bear. This part of the fun was rather tedious and unpleasant. He hung up the skin and hams, then we went down to the creek and washed our hands.

The old man was jubilant. He thawed out wonderfully, and I saw readily enough that I and the shot-gun had climbed considerably in his estimation. But I could not guess that within the next ten minutes Lewis was to become my sworn friend for life.

He wanted to hurry home to get his horse for the purpose of packing-in the bear, and he told me that one big pool formed by the creek was jammed so full of logs that we could cross dry-footed and make a bee-line for his house.

When we reached the jam, I didn't like its look, but Lewis said, "It's easy; I'll learn you how to 
skip 'em." He did, with variations not on his programme.

The logs appeared to be firm enough until he was halfway across. Then he stopped and laughingly told me to follow. As he spoke, either his foot slipped, or the log he was on turned - anyway, he disappeared. I had just begun to laugh, when I saw the disturbed logs draw close together over the one open space which Lewis had found in his descent. Down went the gun, the coat fell on a log three jumps from there, and the last bound of a mad rush landed me on the log Lewis had just vacated. The shock separated the log a few inches from its neighbor, and with a foot upon each I strained to broaden the gap. In an instant they were a couple of feet apart, and I dropped between them into water up to my armpits. With an arm over each $\log I$ hung and worked my long legs scissors-fashion through the water. Old Lewis was there all right, tumbling about in the liveliest kind of way, and I hadn't kicked three times before he seized me by the thigh and climbed up my body like a cat scaling a fence post. The first thing he did was to spout about a pint of water into my face, then he yelled like an Indian.

There wasn't anything much the matter with him, but he was about as badly scared a man as I have ever seen. He recovered in a moment, and we both went ashore to strip for the work of securing the rifle. This was accomplished by forcing the logs well apart and prodding for the rifle with a stout branch. As the water was barely six feet deep we soon located the weapon, then Lewis held 
the branch firmly while I climbed down it and returned. Then we went ashore and had the delayed laugh out. Lewis told me how it felt to be under water and vainly butting one's head against a roof of logs. Later when we parted, he wrung my hand and told me this: "Put her thar, Canady. I ain't the feller to forget bein' snaked outen a scrape like that. Ef it's a go, we'll hunt pardners this fall an' trap her out till spring." And we did. 


\section{CIIAIPTIEIR XXS.}

\section{IFOUIR OIF A}

\section{MRINID。}

I HAD just left the horse show and was glad of it, for it was much nicer to dawdle along the east side of the Square. It was a glorious night, moony and sweetly calm - the finest imaginable correction for the overdose inside the Garden. Suddenly, "Hello!" said somebody close by. I looked $u p$ - I stood a fraction over six feet high - yet I looked up.

What I saw was worth several long looks. One doesn't often see a middle-aged man who stands six-feet-three, on legs as straight as ramrods; above them, a waist like a healthy girl's, chest and shoulders worthy of old Hercules himself, and topped off with a big handsome face. The carelessly swinging covert-coat revealed an expanse of white which looked like a tombstone erected to the memory of clean, sagacious living.

"This is curious," he said in a hearty voice. "Not half an hour ago we were speaking about you. I was wondering if you were game for a day's Bob White shooting on Long Island, Staten Island, or anywhere else within easy reach. I've a friend from England, a parson and a good sort, who is eager to try what he calls 'quail,' as we did until last year."

"The whole thing's curious, Doctor," I replied, "for it happens I've a pressing invitation, good for a 
couple of friends, too, to try a bit of sport in Pennsylvania. I know the ground, and my friend has a good dog."

In very few minutes all details were settled, and we parted with the understanding that he and his clerical friend were to meet me at the Jersey side in time for a convenient train. When we met, I was rather startled, for the friend stood fully six-feet-four, and the pair of 'em, in tweed, suggested a couple of stately brown-stone fronts. The new parson was precisely the sort of friend the other might be expected to have.

Now, until we had left the train at our destination, I clean forgot what manner of man would meet us; but presently, as a truly gigantic figure bore down upon us, it came over me. It looked like a case of six-feet-one, six-feet-three, six-feet-four, and one for His Nobbs, for he stood six-feet-six. The fact that our guide had taken his turn at the reading-desk, an occasional whack at the pulpit, and actually was a church warden at that blessed moment, didn't lessen the fun any.

"What are you giggling at?" curtly demanded my parson, and the twinkle in his blue eye was irresistible.

"I - I hardly know," I stuttered. "What is this outfit, anyhow, a high-church deputation, or just an accident? You know I'm the son of an archdeacon."

"True, I'd forgotten that," he retorted. "It does look a bit shoppy, and as you're an unregenerate ruffian, we'll have to call you the Lay Delegate."

The Pennsylvanian, at a reasonable hour in the 
morning, had a smart team hooked to a democrat wagon, and the first ground was only about five miles away. He had a businesslike-looking pointer, and we were to pick up another dog. Even so late in the season that portion of the state forms an exceedingly attractive picture. It is true we had missed the full glory of the turning leaf, but there still lingered much warmth in the browning foliage, while blue hills, dimly seen through silvery haze, formed a superb background.

The ground looked almost too clean for quail, but presently our guide pulled up his team and exclaimed - "See 'em crossin' - thar they be!" As we looked a cock quail sprinted across and was closely followed by half-a-dozen birds, seemingly a bit larger than the ordinary type.

"Out with you, Lay Delegate - we'll hold the dogs!" commanded the parsons, and as they positively refused the chance, I speedily unlimbered.

"Birr!-birr-birr-birr!" Not the expected half dozen, but fully twenty birds sprang yards into the air. Two cocks and a hen streamed fair across the road, and the stopping of the white throats was a crisply easy task. As I looked toward the wagon, two stately figures rose and stood respectfully uncovered. Mentally, I could see stained-glass windows close behind 'em.

"Them's willow legs!" declared the guide, positively, as I handed up the birds. Needless to say the quail were the common type, although unusually fine and large.

Very pretty but rather peculiar shooting followed. The ground was so clean that birds flushed at from 
ten to fifteen yards. The dogs, however, proved to be of the useful, pottering sort, working with almost exasperating carefulness and propping the instant they made game.

But the parsons were the real joy of the day. I had rashly concluded that the friend never could equal the other's acknowledged skill, but I acquired much wisdom within half an hour. After four straight, clean kills, I put away the pipe and began to get square-jawed. It was beautiful to watch their clean, snappy action and the smoke-like puffs of feathers which never come save from a bird fairly centred. When my fifth was clean muffed, there sounded a soft "Ah!" which was immediately followed by the spiteful squinge of smokeless, and the bird went down like a rag.

From that on the Lay Delegate had a very hard time trying to curb the impetuosity of the rectors. I got one of 'em about the ninth bird, but the other proved absolutely ungettable, for he hung to his saving lead till the shadows lengthened and the blue hills blurred. The other, the friend, struggled nobly, but I managed to keep him one notch behind. In justice to him, only his lack of practice at the game saved me.

When we reached the wagon, I felt like a man who had enjoyed an almost perfect day. They were so enthusiastic - so clever - so crisply clean of speech and thought - that they added a peculiar zest to the thing. For once there had been a threecornered shooting party without flask, shady yarn, or any of those really not serious lapses, which yet occur and jar the sweet wholesomeness of a sport which 
should be as clean as the soul of a child. There were, however, jokes and anecdotes a-plenty, prime good fellowship and pipes - in fine, all a decent man could ask for. "And," thinks I to myself, "these are the men I was a wee bit shy about and was secretly dubious of in the matter of their ability both as field-workers and good fellows. Never again for me the hesitancy. Henceforth parsons for mine! They elevate every phase of the fun."

As we were all pretty tired, it was voted to sleep at the small hostelry, and roll comfortably home next day. Our guide went to his house, and we loafed all we could over an excellent supper, and at last stepped upon the piazza for a few breaths of sweet air before turning in. All three rooms commanded the street. As we stood upon the piazza the air seemed filled with a peculiar, silvery mist, to which the faint moonlight imparted an almost uncanny effect. On the line of the fence opposite a single, tall, white thing showed in an undecided sort of way.

In a spirit of sheer idleness, and because we couldn't make it out from where we were, we strolled toward it. It proved to be a long, bottle-shaped board upon which was an "ad" of somebody's whiskey!

"Strange, how deceiving this light is - that board looked to be fully sixty yards away, yet it's but forty-five," remarked my parson, as we regained the piazza.

"Not six inches over forty-two, I should say," said the friend, positively. "What do you think?" he added, speaking to me. 
"About forty - no more - light's baffling," I replied.

Like men who have nothing to worry about we chaffed each other unmercifully concerning our several abilities at judging distance. On a sudden it flashed into my mind that both the others had returned with most stately strides! Stepping it off ! And in an instant I became worldly and - and wary.

"Tell you what we'll do," exclaimed my parson, as we turned into the house - "I say forty-five yards - you say forty-two, and the Lay Delegate says forty. We'll measure it in the morning and learn who has the truer eye - and - the poorest guesser shall pay the bill for all. How's that?" We agreed, and the host grinned cheerfully. Presently he produced a huge tape-line and remarked - "There's the settler - what's the matter with a-measuring of her right now?"

My parson took the tape, pulled out a few feet, wound them back, seemed to study a moment, then said: "No use bothering now, I'm for bed: we can settle the thing in the morning," and upstairs he marched, after placing the tape upon a small bracket in the hall.

For some reason I was extremely wakeful. For a long time I lay thinking of many things and incidentally listening like a deer. At last there came a sound - the slow creaking of a bed, followed by an uncertain rustling. Then a door creaked, stopped, and again creaked, and presently came the muffled pat-pat of cautious feet. My window was wide open, so I noiselessly moved until I could command the 
street and the white sign in dispute. After what felt like fifteen minutes, a board outside groaned, and a moment later a very tall form moved dimly in the street. There came a steady purring sound as the figure advanced, and I chuckled, for only a tapeline makes that sound. Presently the figure reached the sign, there was a trifling crash. The white thing moved a few feet in my direction, then lo! it stood stiffly in position, and I heard the winding-in of the tape. It was now exactly forty-five yards away.

After a bit he stole back, and I waited. Shortly there was again a form in the road, again the measuring, shifting of the mark, and winding up.

"She's in the forty-two hole now, all right, but she'll stand even forty when I get through with her." I chuckled as I waited for the other fellow to get asleep, or at least settle down. I can cat-foot like the real thing, and the way I finally drifted down to that tape and out to the post was a triumph. The distance from the scraper to the sign was as near forty-two yards as it could be made. In a moment the mark was shifted to the even forty. I restored the tape to its place and regained my room without creaking a board, and soon I was sound asleep.

"How about that sign-board - hadn't you best take a look at it in daylight?" queried the host, after breakfast the next morning.

"I'm game to stick to my figure; we'll measure presently," I replied.

"The same here," and "Here," said the parsons, gravely.

"Let me see," said the host to my parson - "you 
said forty-five yards, and you," turning to the other, "said forty-two, and Dellygait here, he took even forty for his'n. You men are mighty poor guessers. Why, you ain't none of you within five yards of the actool distance - that is, not if I know anything."

Each of us told him he surely was wrong, to which he retorted that he'd bet our total bills against a "ten spot" that he was nearer right than we were. The parsons being out of the question, I took him up.

Before we could start for the measuring, we heard a cheery voice and a heavy step, and into the room strode our gigantic guide.

" Mornin'. Thought I'd just step in to see how you'd rested up."

We assured him that we never felt better; then laughingly explained about the wager and that we were just going to measure the distance and learn who was the victim. He gave a quick, peculiar gasp, then his broad face set in an expression of stolid indifference, but for some reason his eye seemed to fairly blaze with delight.

"Lemme see," he said, "you say forty-five, and you forty-two, you forty, and the Boss here bets none of you is within five yards of the correct figure. Well, one thing's certain - the Boss ain't in it!"

"That so? Bet you five I win," chuckled the Boss.

"I'll just have to go you!" retorted our guide, and they put up the money.

The Boss and the guide did the measuring while the rest of us looked closely on. They had to do it over three times before both had to own that the 
truthful tape made the distance - exactly forty-six yards four inches!

Never had I beheld three such faces of mystified wonder, but the Boss was the worst. He finally gasped out — "Wuh - wuh - wull — it's - one on -me! But I'll be chucked if I see how it came about!"

Some time later he shook hands with us and said he hoped we'd come again soon, but his eyes had a far-away look and his voice lacked its customary ring. The guide, however, kept grunting to himself, and at the station he finally said:-

"I don't just savvy that there betting proposition yet. There's something awful funny about it. He feels mighty sick back there 'bout something. Mebbe he knowed that there board had been moved and mebbe he didn't." We were guiltily looking various ways. "You see them whiskey-signs is also half-mile posts. They're placed by the firm along the main roads, and the pesky boys here'bouts thinks its mighty smart to keep a-shiftin' of 'em. Dunno why, but they do it. Fact is I'm paid a little by the agent to set up them signs and sorter look after 'em and keep 'em somewhere near their proper places. I've put yonder one back a dozen times. I found she was away out this mornin' as I came in, so I set her back."

For a long time we smoked and chatted in comfort, but at last my parson glanced quizzically from one to the other, and said what I knew he would say before we parted. He told of the little joke he had planned, and how, of course, he had intended to reimburse the loser after the joke had gone far 
enough. This we knew was true. To his great astonishment his friend presently told how he had heard the other, had watched, twigged the joke, and later had slipped out and shifted the board; also, of course, intending to tell later.

They had a lot of fun over it, and hearty were their guffaws. Finally, after those grand fellows had laughed and slapped each other's backs like big care-free boys, I - well, I told my story. It was a pity our host was not there to join us. For such high church folk we certainly played it low down. 


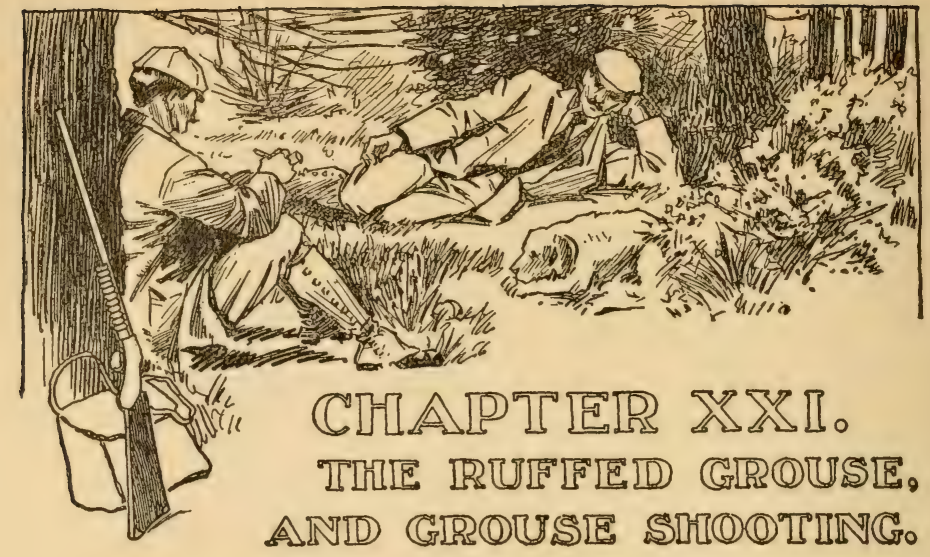

If the red grouse of Britain is, as I believe him to be, the king of the entire grouse family, then, of a surety, the next best one, our own ruffed bird, should be president of feathered Americans and governorgeneral of wilder Canada. Nor is the premier position among the grouse of this continent a trifling honor, for we have many species and good gamebirds withal. Largest of these is the big sage grouse, which, unfortunately, owing to its diet, is not a delicacy upon the board. Much better known, and as much better in every other way, are the pinnated grouse - the prairie chicken - and its varieties, haunters of the great grassy seas of the prairie states and northwestern Canada. One variety, the heath hen, used to be common in the Eastern States, but it is now confined to Martha's Vineyard. That rare good bird, the sharp-tail grouse of the prairies, is by many preferred to its blunt-tailed cousin, the " chicken." The large dusky grouse, second in size only to the sage grouse, or cock of the plains, inhabits the forested ranges of the West from New Mexico to Alaska, while, in 
The Ruffed Grouse and Grouse Shooting 285

addition, we have the Canada grouse, or spruce partridge, and the beautiful willow ptarmigan and its near relatives. Of course the discriminating eye of science divides and subdivides these groups into yet more races and varieties, but these finer distinctions need not be dwelt upon, as the present point of view is from the sporting rather than the scientific side.

That so many men prefer the "chicken" and sharp-tail shooting of the prairies to any other form of sport with the grouse does not of necessity prove the superiority of the work in the open. I have no fault to find with the prairie birds, - too many golden memories of flawless days in state and province yet linger for that, - but I prefer to shoot ruffed grouse. The prairie shooting is, as a rule, a bit too easy all round, and there is just a trifle too much of sameness about it. You drive in solid comfort for miles after fast, wide-ranging dogs; you get down to shoot, climb up again to ride, and so it goes for as long as you please. Of course, it is fun no end, and certainly no other shooting affords better opportunity for fine work by the dogs, and this, to me, is its most attractive feature. Its real weaknesses are first, that it is too lazy work to long satisfy an energetic, red-blooded man; second, it lacks the picturesque, for wild, breezy, and free as the great plains are, there is a monotony in apparently limitless leagues of grass, only broken by scattered bluffs, in themselves only pleasing because of the slight variety they impart to the scene. Again, if I may put it so, you can see too much - i.e. you know too far in advance precisely what 
is going to happen. There are too few surprises and hurry calls for the exercise of one's resourceful craft. When birds are plentiful, it is just the thing for a man who has travelled far for his sport, and who wants all the actual shooting possible during a limited holiday, but it never can present that charm of charms - the infinite variety of ruffed grouse shooting.

Let not the reader for one moment imagine that I do not love the plains and the sport they afford; but in a sportsman's heart, as in a mother's, there is room for many loves, and I fear that if mine were searched, there would be found, close-cuddled near the centre and almost crowding small Boh from his place, a bigger bird, wearing ruffs upon his neck, and capable of spreading a most noble fan-tail. Then again, the prairie shooting, as a test of skill, which ever is a delight to keen men, lacks some valuable accessories. The machine-like precision of your crack performer of the grass lands is all very well, and is interesting so far as it goes; but it cannot possibly rival the rapid work in heavy cover, where conditions vary with every shot. I have heard men boast of fine shooting at chickens in tall corn. That is all right, and it may have been rather difficult; but how would it have been with shotstopping trees instead of yielding corn - or, in other words, ruffed grouse shooting instead of chicken shooting?

To my mind one of those rarely enjoyed really good days with ruffed grouse is the very finest test of a man's skill and resourcefulness, for both surely will be taxed to the uttermost. And each clean 
The Ruffed Grouse and Grouse Shooting 287

kill will be long remembered. I suppose I have killed as many grouse of all varieties as the average man who shoots purely for pleasure, yet the incidents of not a few days on the prairie are almost forgotten, while those of ruffed grouse covers absolutely refuse to down. The remains of shells of mine might be found in the woods of Nova Scotia, New Brunswick, Ontario, Quebec, Maine, Michigan, Wisconsin, Manitoba, Assiniboia, Alberta, British Columbia, Vancouver Island, Minnesota, the Dakotas, Pennsylvania, and, of course, New York, and along the eastern coast. All these combined would form a very tidy little shooting-ground, with ruffed grouse in most of it. Yet I feel free to say that, could the fired shells be placed in one pile, and the skulls of the slain grouse in a second, the scenic effect would be mighty apt to suggest a brassmounted mountain and a none too stately mole-hill. Those who have had much to do with ruffed grouse could tell which would be the mole-hill without bothering about going to look.

The very difficulty of the shooting is one of its greatest charms. Beautiful, strong, and swift, the grouse also is no mean tactician. He not only chooses the most difficult ground, but he is artful to a degree in baffling the efforts of his pursuer. When flushed, he rises with a sudden hollow boom of whirring pinions and makes off with a headlong, reckless dash suggestive of anything rather than cool calculation. Yet those who have closely studied his methods know that no other bird is so quick to take advantage of every natural shelter which can stop the flight of shot. A grouse compelled to rise 
in a comparatively open spot will dart like a feathered cannon-ball for the nearest cover, or if near a big tree, he will whisk behind the trunk, and, keeping it between himself and the gun, buzz away to safety. Flushed halfway up some hillside - a favorite haunt - he will slant downward at an electric clip, offering an exceedingly difficult mark. At certain seasons he is found in outlying thickets, frequently at a considerable distance from the woods proper. Under such conditions he trusts to his speed as he hums away to the saving trees, but at the same time he seldom forgets to take every advantage of the lay of the cover, scant though it may be. His golden rule seems to be: "Start precisely when the man is sure you won't, go as fast as you can without actually setting yourself afire, and get everything that will stop shot between yourself and the gun."

The one serious weakness in the grouse's system of defensive tactics is his habit of treeing when flushed by a dog. This is an interesting point, as it strikingly illustrates the folly of sticking to oldfashioned methods after improvements have been introduced, and also that folly of all follies - underestimating the ability of your opponent. \#ons on æons ago the grouse developed that trick of going to a tree to avoid peril terrestrial, and no doubt it considered itself a very smart bird. At that time, strangely enough, its two winning cards in the game of life and death were taking to a tree and leaving a tree. Being a bud-eater, at certain seasons the grouse naturally sought the trees for food. Among the branches it was comparatively safe from quadrupeds, although some of its foes were clever climbers. 
But there were others - the birds of prey - and to avoid these the grouse went back to earth. So it played its game of going to the trees to avoid fourfooted foes, and dropping to the rocks and brush to baffle winged ones, and this must have answered very well for a long time, for the grouse flourished and waxed fat. The one human foe was then an Indian, clever with bow and arrow and snares; but still the treeing trick was useful, for good arrows were easily lost if shot upward among trees, the grouse was comparatively small game, while the Indian hated to make arrows as he hated work in general. But the old-fashioned firearm eventually became common, and at once the grouse's erstwhile strong point became a weakness.

I have no doubt that birds once wounded in trees may have learned to trust to their wings when next man appeared, for to-day the grouse, except in remote corners, seldom trees unless the man be accompanied by a dog. To the birds the dog is merely the old, four-footed peril - a fox-like creature unable to climb - from which a tree is an absolutely safe sanctuary. Hence, we see birds tree above the dog and remain calmly looking down upon the intruder, and even moving upon the limbs as though only slightly interested in the whole business. But let the man follow the dog, and a change takes place. One of two things happens - either the grouse leave the tree, or they stretch to their full height and remain motionless. When so posed, only an experienced eye is apt to detect them, for they would easily pass for so many decayed and broken stubs. Even the skilled sportsman, who knows this habit of the 
grouse, and who is warned by the actions of the dog that the game is somewhere in the tree immediately above, frequently has difficulty in locating the quarry. His safest plan is first to let his eye follow the trunk to the top, as the probability is that the game will be perched near the trunk. If this fails, the next thing is to begin with the lowest limb and examine it from the trunk to tip, and repeat the process limb after limb. This, of course, must eventually locate the game, but the sportsman will do well to keep his gun ready for instant action. Strange as it may appear, the bird seems to know the instant it is observed; then it is apt to at once take wing.

Most people who have enjoyed the pleasures of the woodland path have heard the peculiar ventriloquial sound, known as the drumming of the ruffed grouse. This drumming, while most frequently heard during the breeding season, is continued at intervals during the summer and autumn months. It is a low, muffled beating, yet it may be heard at a considerable distance. It is caused by a peculiar beating of the wings, beginning with measured strokes which rapidly run into each other - buff buff - buff - buff - bur-r-r. It is a popular belief that the grouse always drums upon a fallen log and produces the sound by beating the log with stiffened wings. This is erroneous, for the bird will drum upon a stone, a grassy or mossy mound, or upon the ground, as suits its fancy. It may be a call to the female, but it certainly is continued long after the breeding season. I have a notion that the motive for the drumming is the same which prompts the barnyard cock to clap his wings and 
crow whenever the humor strikes him. He just feels that way. In any event the sound is a baffling one, which may appear to come in turn from right, left, front, and rear, although the bird has not changed position. It is no easy task to stalk the concealed drummer; yet any one who has the patience to advance only when the drum is sounding, and to remain motionless but alert during the intervals, may obtain a view of the queer performance. I have seen grouse drum many times and at varying distances. Most of these birds were upon logs, and between the acts they moved to and fro with mincing steps, while they appeared to glance sharply in every direction as though on the lookout for an approaching female, or a possible foe. When ready to drum, they stood erect with head thrown back and the beautiful tail raised high and full-spread like a fan. The wings were spread to their full extent, and then brought sharply against the sides in successive strokes, which increased in rapidity till the separate strokes were blurred together in a rolling sound somewhat like low, distant thunder, or the rumble of a carriage rapidly driven over a short wooden bridge. A clever boxer with soft gloves might drum an imitation of it upon a punching-bag. The sound of a boot against a foot-ball is not unlike the peculiar noise of the opening beat.

Now, this bears upon the oft-disputed question of whether the bird's wings strike the log or the bird's body. I say the body and the body only, although of course they may now and then accidentally strike whatever the bird may be standing upon. Years ago we had a huge gobbler of half-wild blood, and 
this turkey, as is common to his kind, used to strut and show off during the breeding season. I used to stalk the old fool when he was in an ecstasy of strutting, get astride him and hold him with my arms about his broad breast. He seemed to be full of air, like a huge bladder, and I'd slap him on crop and sides as fast as I could till he'd let the air out of his mouth with a rush. Then I'd get off him and leg it for all I was worth to the nearest cover, for he was a haughty old fowl and had impressive spurs. The sound of my hands batting him was very like the drumming of the grouse, and I suspect that the grouse, a distant relative of the gobbler, fills certain air-sacs with ozone, and beats himself with his wings to produce his muffled drumming. The well-known clapping of the wings by domestic cocks and pigeons, and the whirring of pheasants, merely are other forms of the noisy wing-action. Those who have used turkey-wing brushes about stove, or hearth, know how soon the very strong feathers wear away, and a grouse's much weaker wing never could stand the harsher work of violent thumping against log, or stone. Furthermore, a grouse can and does often drum upon the ground, an ant-hill, and a mossy knoll, not one of which would give forth sound in response to a wing-stroke. The very flight of the bird when alarmed proves what a row the wings can produce working against air alone, and this noise is under the bird's control, for both ruffed grouse and Bob Whites have what may be termed the silent flush and flight for ordinary occasions. Either can rise when so inclined with no more noise than would be made by any other round-winged bird of equal size. 


\section{The Ruffed Grouse and Grouse Shooting 293}

The ruffed grouse builds a leaf-lined nest upon the ground, usually at the base of some tree, or beside a log. The eggs number from eight to fourteen, and are buff-colored, which greatly aids their concealment where old leaves are apt to be lying about. The young are active and very clever at hiding, which is aided by the general brownish effect of the downy covering. The mother is a devoted parent, never hesitating to throw herself in the path of an intruder and, by simulating lameness, endeavoring to draw the danger toward herself. This pretty deceit is one of the most touching sights which reward the observant bird-lover. The young usually remain together until the late fall, and, if undisturbed, perhaps throughout the winter.

The turning of the leaf brings the sportsman's merry season. In the mellow beauty of brave old autumn's ruddy prime comes the cream of the grouse shooting, although the sport continues until the white, sharp days of the sterner season. Let one day serve as a picture of it at its best.

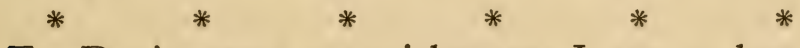

To Doc's great astonishment, I am at last half ready when the trap pulls up at the gate. Old Mark, the great roan king of the native setters, rests his broad muzzle upon the dash-board and with a thump of his tail bids me welcome. At my heels is Don, cold-nosed, wire-thewed, keen as a spring. In fact his plainly prominent ribs suggest that a spiral spring might have constituted his last meal, but his eyes are clear as morning drops on grass, and his lemon head and snowwhite body shine like satin. 
"The 'bull' looks fit this morning," placidly remarks Doc, who hates a pointer worse than a blank day.

"Yep, he's good to-day; and the old Newfoundland's able to ride a mile or so, apparently," I sweetly retort, for we love each other, we two, and each has a cracking good dog and knows it.

"Shall the bow-legged bull ride - it's five miles, you know?" continues Doc, insinuatingly.

"There's no ambulance call in my kennel!" I snap back.

"Might be handy before night," sighs Doc, and we both laugh as I climb up.

As we bowl along for mile after mile, Don's nose is within an inch of the horse's heels. There is no dust; he loves to travel so, and seldom indeed has he to break from his own peculiarly rapid trot. Under the trap he is safe from attacks by farm dogs, which, if they try to dash in from the side, merely take a tour with a wheel or get run over. Woe be unto the brute determined enough to attempt a rear raid! Don, when put to it, would sooner fight than eat, and he is always in fine condition. Five miles from home we reach the first of the chosen cover. Five minutes later the nag is comfortable in an old log shed, and we are ready for business.

It is a good ruffed grouse country. Leaving the well-cultivated fields behind, we enter an irregular belt of clearing where old brush piles and stumps are overhung with a snarl of briers and slim second growths. Back of this the unbroken forest spreads for miles, while near its edge winds the broad bed 
The Ruffed Grouse and Grouse Shooting 295

of an almost dried-up creek. This is a confusion of comparatively low cover. The larger trees are not too close together, but quick, snappy work must be the order in most of the brush. We decide to work along the face of the woods until the comparative open has been thoroughly beaten. Any grouse found in outlying clumps will surely dash for the woods, and our method means that most chances will be side shots, when the trick of dodging behind trees will avail but little. The dogs are given the word and we move forward about forty yards apart. Now comes a beautiful exhibition of dog work. The big setter, the best dog on ruffed grouse in the county, knows exactly what is required of him; the pointer, the best quail dog on a grouse day that ever I saw, knows his mighty rival too well to attempt any liberties. So instead of sailing away at top speed and splitting two-hundred-yard tacks, they merely canter, and while scorning to follow each other, each keeps close watch of the other's movements. Suddenly the pointer stops in the middle of a stride, and like his shadow, the great roan loses motion. My whistle, held pipe-fashion, purrs a low warning (the voice alarms grouse), and the dogs are as steady as trees. In a moment a white and gray ball goes bouncing toward a brush heap, and the pointer's tense muscles slacken. It is too early in the day for fur, and Don knows that a something which stingeth like an adder lurks in my pocket. So he gives a yearning look at the vanishing cottontail, and the quest continues.

A sudden bursting roar of wings, a clash of twigs, 
a swirl of painted leaves, and a brown shell is boring a hole through sunlit space. $\mathrm{He}$ is a beautiful picture as he crosses with outstretched neck leading an electric fan of wings. Not caring to stand idly while a grand grouse plucked itself, or cut down a tree through having lost control of its brake, I snapped the twelve into position and whirled the tapered tubes until they swung two feet ahead of the flattened ruffs. It was a glorious picture, yet a kaleidoscopic effect, for as my finger pressed the trigger, the feathered fan stopped buzzing, the beautiful head went up, and I heard the spiteful "squinge" of modern powder a second before my shoulder felt the jar of my own weapon. Both dogs went down, and through the brush came Doc. His blue eye sparkled, and it asked a question as plainly as words could have done. I felt like lying, for it was a very close thing, but sportsmanship is mighty.

"Aprez vous!" I sadly muttered in about all the language of the courts I am aware of, and then I hustled in a second barrel of - "You-red-headed-foolif-you-crossfire-me-again-I'll-fill-you-full-of-shot!"

"Gad! he's a beaut!" lisped Doc, as he smoothed the lovely plumage. "And he's fat, too!" he continued, as he slid what had been within one inch of being mine into his pocket. Then we looked at each other and grinned, for each knew how slim had been his chance.

The dogs soon got to work again, and a memorable bit of sport followed. Dame Fortune was in a generous mood. Within five minutes the white dog had evened matters by pinning a big cock 
The Ruffed Grouse and Grouse Shooting 297

grouse in the centre of an almost open space. Doc thought it was a rabbit, and sent me over. There was a clump of dog-roses, and while I was hoping a big grouse might chance to be there, the very bird roared up and was clean killed. Some way, Doc's mirth this time was not what might be termed noisy.

The next notable event was the pitching of a missed bird into an outlying thicket on my side of the beat. I followed the bird and killed it. At the report a second rose, which also was killed; then another and another whizzed away before I could reload. As Doc rushed into the open, still another bird roared up and collapsed. Then the dogs drew cautiously on; something went out one side, while something else fluttered near me. We fired almost together, and as I took a fat woodcock from Mark, Doc shouted - "I've got your rabbit - do you want him?"

When he saw the cock, we ceased to be friends and both tramped into the cover without a word. Soon both barrels told that Doc was busy, and the next moment a bullet-headed beauty came twittering past me, but concluded to bide a wee. For a while, it looked like that rare, highly prized sport, mixed cock and grouse shooting, but only one more longbill was found.

The next move was to the bed of the creek, and we advanced one on either side, the dogs working between. Prettier ground could not have been chosen. The course of the creek's bed was like a winding corridor walled by sturdy trees, and no matter which direction birds took, one gun was 
certain to have a clear chance. The dogs toiled slowly through the tangled stuff, while we followed abreast. Every now and then would come the impressive pause of one or other dog, almost immediately followed by the hollow thunder of strong wings and the rush of a swift brown body. Usually one barrel, sometimes two, did the trick. Once a bird boomed away with four charges of shot in vain pursuit. The incident caused a hearty laugh and a lively exchange of that sort of talk which might be dangerous among dry leaves. But little things of that sort seldom are hotter than tabasco. In time the end of the cover was reached and we pulled up for a rest and a bite. Our four-footed friends, too, are quite willing to roll and stretch on the soft fall grass. The big roan showed no trace of the rather heavy campaign, but the white fellow's rat-tail was crimson for fully four inches and his flanks were streaked with plenty of that same red badge of courage.

To my mind, one of the happiest periods of a good day's sport is when the pipes are drawing well after the midday snack. The dogs have had their crusts and stretch at ease in the cool grass. The coats with bulging pockets hang near by. There is more choice ground to be beaten and plenty of daylight for the work, and even a blank afternoon cannot spoil the day. And then the handling and smoothing of the beautiful prizes so fairly earned by skill and manly, sportsmanlike methods. Every bird has had a fair chance and has been cut down as mercifully as possible. To lie upon sweet grass at the fringe of a noble wood with a sun-kissed sea of 
The Ruffed Grouse and Grouse Sbooting 299

stubble spreading far before is no great hardship. The view is ringed with fire where maples and nut trees mass their glowing; the fence lines, where the creepers, briers, and sumachs are, show like rivulets of flame flowing down easy slopes, and over all the season's lovely haze, the smoke of the earth's burntoffering for a bounteous field.

Doc knocks the ashes from his pipe, and at the sound the rested dogs spring up ready for more work.

Quick echoes wake within the woods, the cut leaves drift, the dogs toil on while shadows creep. From huge halted billows of forest we wade through the soundless surf of lesser growths and reach the open. Far away the sun's failing red dims like a coal amid misty ashes.

The horse is glad to see us. Food and water a-plenty he has had, but his own stable is home, and he wants to get there. This time both dogs ride. Both have worked nobly and honors are easy. Few words are spoken. The quick hoofs drum the white road in regular cadence. Fence, field, and orchard glide past in dimming procession, and twin puffs of fragrant smoke drift rearward to mingle with the mist, the fruity odors, and the sweetness of it all. 


\section{CIIADTIER XXXII.}

\section{RQBEERTS WUIITIE JIR。}

When one of those ordinary little wretches, a human baby, is born, it may be interesting to two, four, six, or even a few more people; but, fairly considered, it doesn't amount to very much. A choice specimen might weigh eight or nine pounds, but the material is rather mushy, and of questionable value. It isn't quite so wrinkled as a decent puppy, nor so pink as a new-born rabbit, nor so agile as a young mud-turtle when turned upon its back. In fact, only strongly prejudiced folk can see anything in it. While the ordinary babe may ripen into a President, or some old thing like that, it requires a heap of time and teaching before it can learn its own name, let alone its politics and their possibilities.

Young Robert White, however, was a marked exception. An American, the first act of his little life was a blow for freedom, for when he came to himself, he was in prison. He never knew it, but he had been shut up for nearly thirty days, and that for no crime. For all we know to the contrary, he may have chafed under the yolk, but in any event he gradually overcame that difficulty, and decided to break jail. As the cell in which he was confined was so small as to effectually prevent free movement, and one part of the wall was as easy as another, he attacked that section which lay directly 


\section{Robert White, Jr.}

before his nose. The said nose was equipped with a hard little point, and he pushed it against the wall, and presently first cracked and then shattered a tiny section, through which at once poured his first direct supply of air. It was gratefully warm and wondrously invigorating.

A few moments after Robert had made his first breach in his prison wall, his instinct prompted him to twist a little to one side and repeat his bill-pushing. He did this again and again, sometimes hurriedly, but with occasional long pauses, until a regular line of small fractures extended almost around the wall. Then he struggled desperately, and lo! the dome above his head quivered, yielded, and fell away, and the first kicks of his untried little legs caused him to tumble sprawling into warm darkness. He was moist, almost naked, and tremblingly weak, but he was old Robert White's son now, with no further use for a shell. That there were other shells - long and round and brass-ended, he did not know, and not knowing, did not care.

It was pitch dark, yet amazingly comfortable, where he lay thrilling with new life. Pressing upon him was a something deliciously soft and soothing. The touch of it seemed to lend strength as the minutes passed; so he gratefully rubbed his head against it, and resolved to maintain his present position at all hazards. He did not know why he should do so, yet something told him to remain for the time exactly where he was and to resist anything which tried to move him. And he did resist, and presently he had need to, for damp, warm things began to press against him from all directions. He 
did not object to them in the least so long as they did not force him to shift his position. When they crowded too closely, he merely braced and pushed with all his little might, yet ever good-naturedly, for the whole thing was snugly warm and drowsily pleasant.

He did not know it, but close around him lay no less than eight small brothers and an even halfdozen of equally small sisters, and all so exactly alike that only their proudly happy mother could tell one from the other. But she knew every one of them, and in some mysterious way her wonderful mother-love was divided into fifteen exactly even shares. The other fourteen youngsters felt precisely as did Robert, so when his damp coat presently dried and fuzzed out all over him to form a beautiful furlike wrap of rich chestnut and cream, their small covers had done the same.

This state of affairs continued for some hours, in fact till the burning sun had thoroughly dried even the tangled lower growths. Mother White's beady eyes knew how to read the signs that told when the last drop of dew had evaporated, and at the proper moment the feathery tent was struck, and she daintily stepped forward, leaving the silky mat of crowding youngsters for the first time in their lives entirely uncovered. It is quite safe to say that not one of the lot was either astonished or dismayed by the sudden exposure. It is all very fine for a few peculiarly gifted, or otherwise, folk to minutely describe the joys, sorrows, hopes, fears, and aspirations of young wild things, but the important fact remains that at least one-half of such statements is either 


\section{Robert White, Jr.}

sheer tommy-rot or mere guesswork. While it is quite true that much has been learned, as more remains to be learned, from close observation, it also is true that even the most generously endowed of our writers have not yet quite mastered the art of turning themselves into winged or four-footed creatures at will. Until they have fully mastered that art, which may mean some slight delay, the average, not especially gifted reader may be wise in liberally salting his brain-foods.

Our young Robert, possibly because he was an exception to the general rule, did not at once enter upon an arduous course of study like the brainy birdlings that bloom in books. Instead, he just toddled along with the crowd, dogging his mother's steps until she paused and began to kick the dust about with her feet. Naturally enough, there had been no previous rehearsals of this interesting performance, nor had it been at all discussed; yet the moment he saw her, as it were, "at the bat," he elected himself "short stop," and prepared to play an errorless game. When a few moments later a spotless white object came trundling his way, he gathered it in with a speed and accuracy worthy of a pennant. It was an ant's egg. There were other foods later on, and when he spied something new, he didn't have to run to his mother and ask if the thing was good to eat. His keen eyes merely flashed upon it, decided its value, and he promptly pounced upon or passed by as his curious instinct directed.

For days the youngsters all had a royal time, for life was one grand, sweet feed, sleep, and sun bath. Like the others, Robert grew rapidly, and fairy fans 
of wings replaced the hairy stumps he had first worn. He could run with astonishing speed, and did not hesitate to follow an insect - skip - skip skip, though the chase led him yards from his mother. As yet no startling adventure had befallen him, for his brief experience had been one of peace and plenty; but mischief was brewing. It came without warning, and just how it happened he never knew. He had spied an ant crossing a long, narrow strip of dusty, worn ground, and he dashed with electric speed after the prize. The ant trotted into a wee hole, around which lay a ring of sand grains, and Robert at once got busy. Three kicks of his nimble feet scattered the sand in as many directions, and instantly his stout little bill was pickaxing at the hole. He knew that red ants and white eggs lay just below, and so eager in his work was he that he never looked up till he felt the earth tremble under a mighty measured thud-thudding, the like of which he never had heard.

Out of the corner of an eye he caught a glimpse of an awful shape which towered high in air, and instantly his bent legs straightened and he shot head-first for the grass, which he failed to reach by a few inches. He fell like a frog all stretched out on the bare dust, but once there he remained as motionless as a dead leaf. As he lay, he heard his mother utter what was to him a new cry and it said "hide," but he already had done his best in that direction, and without her telling he knew the slightest motion would be perilous. His little heart was beating over-fast, and his eyes were wild with fear, but he never attempted to straighten a toe that was uncom- 


\section{Robert Wbite, Jr.}

fortably bent. The monster thudded almost upon him, then halted and emitted a thunderous rumbling, the sound of which almost scared Robert to death.

To our ears that sound merely would have meant - "I seen ye skip, ye little cuss, and I see ye a-lyin' there. I must be mighty keerful where I step, for there's a sight o' ye round here an' I wouldn't hurt one o' ye fur a price,"- - for the towering monster, or what to Robert appeared that way, was good Farmer Brown, owner of two hundred acres thereabouts. $\mathrm{He}$ passed along smiling at outstretched Robert, who never even quivered as minute after minute passed away. Robert was anything but comfortable, yet in spite of his accidentally awkward position he never stirred till his mother's voice uttered a peculiar low twitter. At the sound he sprang to his feet and raced to her in time to see the others trooping in from various directions. Not one was missing as she promptly discovered, and after she had led them a few yards from the path all resumed their tireless quest for insect food. The dread of the monster vanished with his disappearance, for young wild things are blessed with exceedingly short memories and never bother about a peril that has passed. Once assured, - and the mother's voice is an assurance beyond question, - they are as unconcerned as though the thing had never happened. Were it not for this their little lives would be an agony of terror, a thing unknown in Nature's beautiful plan.

Long, lazy days passed in pleasant succession, and Robert grew fat and rather long-legged. His erstwhile pretty, downy coat was thin and pale and 
bristling with stubby feathers, and his wings had become goodly mottled fans ample for the covering of his almost bare sides. He could run with astonishing speed, but beyond an occasional fluttering to ease his descent from some log or rail upon which he had climbed, he had not yet used his wings. But there had to be a first time, and when it came, it was a genuine surprise. In a fence corner of the favorite field grew a lot of briers, and close beside them, yet fully exposed to the sun, was a small patch of bare, sandy soil. Mother White knew all about this spot, and when one day she felt the need of a regular dusting, she led the way to it. Squatting on the sand, she raised her plumage almost on end, pecked a few times, scratched a little with her feet, then performed a peculiar scraping with her wings, which presently raised a small cloud of dust and sent grains of sand showering through her loosened plumage.

Robert and the rest scarcely looked at her, but each squatted in a handy place and set to work precisely as she had done. Soon a small cloud of dust almost obscured them. Their dust bath was as cleansing and enjoyable as a plunge into a swimmin'-hole, and for an hour they lazied, dust to the eyes. So dreamily content were they that none noticed an approaching thud-thud, the very same that had previously scared them. Suddenly there was a tremendous crash and a horrible swaying of briers. Without stopping to think Robert sprang into the air and made his wings fairly hum, at the same time and for the first time uttering a shrill "chick-er-ick-tick" of terror. He had no time to 
think of direction, but buzzed away for twenty yards as he happened to be pointed, then sank panting into some green stuff, where he at once crouched.

For the first time in his life he was entirely alone. The novel exertion and the scare combined made his heart thump, and in dread of he knew not what he pressed his scanty plumage close and waited as motionless as a clod. Where his mother had gone he could not even guess. He had heard the roar of her wings, and dimly seen the others leap like big grasshoppers all about him, and that ended his knowledge of the disaster. He knew he had made his first flight, and he wished he hadn't, for he was lost and scared; yet something told him to sit tight and wait. Meanwhile among the briers arose Farmer Brown, and he said: "Durn that rotten rail anyhow! Here I've gone an' skinned my arm fur six inches an' fell atop of my little quails an' most skeered 'em to death, I reckon! The young cusses were takin' a dustin', fur here's their little wallows an' shed feathers, which proves they're gettin' quite sizable."

To Robert that wait seemed dreadfully long; in reality it did not exceed fifteen minutes; but at last came his release. A plaintive whistle, vibrant with tender anxiety, sounded from a near-by thicket. "Kaloi-hee! Ka-loi-hee! Ka-loi-hee!" it said, and as it ended Robert rose to his feet and shook himself. Because he never had been "scattered" before, he never had heard a similar sound; yet he knew his mother's voice and that it meant he should join her. He wasn't quite sure of the direction, so for a moment he waited irresolutely. Again rose the rallying call, louder and clearer, and his keen ears told 
him the exact line to follow. Instantly he straightened up, and for the first time attempted the answering cry. It wasn't much of a cry - rather feeble and a bit broken-reedy, and suggestive of a whining "Thankee-than-kee!" but it was the best he was capable of. Then he ran like a mouse going through grass.

Every now and then he stopped to call and receive instructions, and from various places he could hear the others like himself steering by signal. When finally "Ka-loi-hee!" again sounded, Robert squeaked hasty acknowledgments and sped straight as a bullet to where his mother stood. Half-a-dozen of the others were with her, and presently the rest came sprinting from various directions. In her own way she counted them, and the moment the tally was complete all trace of anxiety left her, and she cautiously led the way to some secluded foragingground.

Weeks passed and the young Whites, with one exception, throve amazingly. Robert himself was nearly as large as his mother. His washy-looking, mottled suit had fallen from him scrap by scrap among briers, grass, and at the dusting-place; the leaden gray of his throat had changed to almost pure white; in fact, in his mother's eyes, he was painfully like his father - that mysterious father whom he never had seen, that is, so far as he knew.

In time the conditions changed. A great storm arose; there was a tremendous clatter in the air and Farmer Brown and other monsters raged and shouted in the fields from morn till dusk. Then the awful disturbance passed, but it had wrought ruin far as 


\section{Robert Wbite, Jr.}

eye could see, except in two directions. The bit of woodland, to which the terrified Whites had fled for shelter, yet remained, but the big field lay bare and bristly with the short, broken stems over which the storm had raged. Of all the glorious cover there was not a vestige with the exception of some thin strips along the fences. Mother White gazed across the waste in amazement. Verily the late Happy Hunting Grounds had been transformed into the other place, and she scarce knew what to do. For that day the lot cowered in the fence corner, picking a few seeds in a half-hearted sort of way, but not daring to leave the shelter, although plenty of scattered grain was plainly visible. As often happens in other families, the one weakling was the hungriest and most reckless. He finally ventured into the stubble and snatched grain after grain, the quest leading him farther and farther from the fence. The others watched enviously, yet heedful of their mother's continued warnings. At last the forager straightened up to force down one more grain into his jammed gullet. His crop stood out hard and round; he was wheat to his mandibles, and the sight of him made the others prepare for a united raid.

Then an awful thing happened. Some yards from his position, the top of a big gray clod showed just above the stubble. Such clods are common in grain fields - the plough turns up a moist chunk which sometimes hardens like a brick and so remains till the grain is cut. But there are few clods exactly like the one in question. Before the eyes of the amazed Whites it presently rolled forward a little - just a little, but it really rolled. Mother White 
saw it, but before she could shrill her warning call, the clod flashed through the air, for an instant seeming like a brindled rabbit, then landed squarely on top of the forager. The horrified watchers stole in haste toward the wood. At its edge Mother White hopped upon a $\log$ and gazed back at the stubble. A gray thing with a dead shape hanging from its mouth was trotting far away. Mother White stood on her tip-toes to watch that dreaded thing, and as she gazed she noticed something else. In the distance beyond the stubble rose a wall of green which she knew to be excellent cover. It was corn, acres upon acres of cool, tangled foliage, beneath which the family could run and dust in safety, and from which they could forage outward for seeds and other foods. The sole difficulty lay in the crossing of the stubble. That was dangerous, she knew; but something had to be done, so she resolved to attempt the trip.

With the lot close at her heels she started along the fence till she marked a long, narrow depression which seemed to cross the stubble. Into this she turned, at first stealthily creeping, then running at half speed. It was a long route, and when she finally halted and stood erect to see if they were not almost there, she was startled to discover that one-third of the distance had yet to be traversed. Her eyes had misjudged the task, for the dwellers in the cover are not accustomed to taking very long looks and seldom bother about anything more than fifty yards away, which accounts for the egregious blunders they frequently make when they happen to get lost and straggle into a town. Far away she saw a dark 
thing drifting in the air, and realizing that there was no secure cover nearer than the corn, she fairly sprinted for that shelter. As she sped her terror increased till she could wait no longer, and with a warning cry she took wing. The others at once sprang into the air and darted after her. Their rising was almost noiseless in marked contrast with the sounding whir of a flush before a man or dog. But this time they had a running start and were not suddenly bounced from a crouching attitude.

Straight before them lay the corn, and they whizzed toward it in straggling order. Fast as she was going, Mother White saw the wheeling thing she had previously marked suddenly flash forward at marvellous speed. Sorely frightened though she was, her mother-love prompted a sharp cry of warning. Those nearest heard and understood, and instead of sailing for the last few yards, they buzzed madly until they struck the dense growth and plunged through it like so many hurled stones. All but one. A drift of floating feathers, a broad-winged, gray form that flapped away in burdened flight, proved that Accipiter velox was well named, and had taken the toll which folk of the cover must pay when they cross their Bridge of Sighs - the broad open.

Because there is none of that which we call lasting grief among the Whites, they speedily forgot their troubles. In the corn they were safe, and for weeks things were delightfully pleasant. Robert and his brothers waxed stout and strong, as did their sisters. The distinguishing marks, the white throats of the one and the soft buff of the other, were alike perfect, and the lot thought nothing of long tramps through 
the now weedy stubble, or whizzing flights back to cover. The corn had lost much of its green, the trees were turning to gold and crimson, but food was almost too easy to find. The night air had grown a trifle chilly, but the Whites were stronger and wiser now; so at dusk they sought the same old sleeping-spot - a little patch of snug grass and catbriers the plough had avoided because of some big roots which lingered there. Robert and all now slept in a little round bunch, from which heads projected like the spokes of a wheel; for in case of a night alarm, when so placed, every one could take wing without interference. Nothing could be finer than the life they led, yet again trouble was brewing.

One fateful day there came another storm. As had happened before, the sky was clear, there was no warning. Even Mother White's weather-wisdom, which could tell well in advance when rain or snow was coming, was at fault. Yet the storm came, and it was something frightful, yet peculiar. All day long it raged, the stout corn swaying and crashing down, till of all that noble growth but a beggarly third at one end of the field remained standing. When the terrified Whites reached the edge of the standing stuff, they scarce could believe their eyes. The ground was almost bare, yet marked with apparently endless rows of stubs, from which the storm had torn the mighty stalks, and these, strange to say, had been whirled together into even, conical piles which dotted the entire space. The blow was one of those cutting things which White brains cannot understand; yet some shelter remained, and into it they timidly crept. 
They had sufficiently recovered to think about breakfast, and Robert himself was leading toward the best spot in the stubble, when there sounded a strange whistle. Never had he heard the like, so he paused to hear more. None of his family ever attempted anything of the kind, for this sound was shrill, trembly, and long-sustained. He was full of curiosity to learn the cause of it, but before he could decide what to do a quick rustling ahead warned him, and he crouched ready to spring. The rustling slowly approached, then abruptly ceased. Uncertain as to its cause, Robert raised a trifle and peered nervously ahead. What he saw almost caused his heart to stand still. Some new kind of monster, black and white, and rather small for a monster, was standing perfectly still a few yards away. He knew the thing was alive, for he could see two staring eyes, which, however, were not looking at him. For many seconds the strange thing remained motionless and he was sorely puzzled. That the thing meant mischief he felt, but he could not understand its method, for what sort of way was it for any dangerous thing to stand still in plain view? His bewilderment was abruptly ended.

The other monster surely was coming! He could hear the thud-thudding, and presently the dreaded noise, something like what he had heard before. To our ears this noise would have meant — "Steady, you beauty! Take the birds to the right, Jim. It's a bevy, sure!"

From just behind Robert heard Mother White's low purring twitter of warning, which he knew meant back to the corn at full speed. For an instant he 
hesitated; then as a tall monster appeared right before him, he sprang as he never had done and whirred his wings like mad. He was at top speed and pointed straight for the corn, when a new noise broke out, and, to his horror, the tip of his right wing refused to work, and despite his desperate efforts he slanted down to the ground. Luckily he did not strike very hard, yet he was jarred and confused and greatly frightened. In an instant he recovered sufficiently to remember what was necessary, and with a quick run he again sprang into the air and desperately beat his wings, only to whirl through a swift semicircle and crash down upon his back. For a few seconds he was too stunned to act, then he recovered and sprang to his feet. If the wing refused to serve, there was an unrivalled pair of legs, and away he raced straight for the old roostingplace, where the roots were in the ground. One of these was hollow, and into the dark hole he dived and crept along a couple of feet till he could go no farther.

For hours he lay there, frightened, very hungry, but determined to stick until he heard his mother's call. It was a terrible day. Strange noises sounded on every side, and twice the black-and-white monster came and snuffed fiercely into the root. The last time it scraped madly with great claws, but suddenly it uttered an awful yell and went away. (Robert didn't know it, but the dog-whip had touched that monster, because the bigger and wiser monster had, as occasionally happens, mistaken a bit of brilliant trailing for chipmunk hunting.)

All disturbance had long ceased when Robert 


\section{Robert White, Jr.}

decided to venture forth. His wing did not greatly pain him, but he was ravenously hungry, which, to the Whites, is much worse than any except serious injuries. He had rammed himself so far into the root that it was difficult to back out against the lay of his feathers, but at last he managed it and emerged much ruffled. A vigorous shake smoothed him and at the same time reminded him of the tipped wing. His instinct told him not to attempt to use it until it felt different, but the thing of pressing importance was food. In less than half an hour he had swallowed all he could hold, and then came anxiety about the others. From our point of view, it would have been much prettier in him to have forgotten food and gone trotting and piping in quest of his beloved kin, especially the small brown mother; but wild things, if hungry, will not pass food for all the sentiment ever miswritten. Hence he fed first, and when full, stood and listened.

There was not a sound. The air was still, and the low sun looked like a crystal globe full of red wine foundering in a sea of silver mist. For once in his life Robert had fed alone and was to sleep alone, and he did not understand why. Mother and the rest were near by and he would call them. "Ka-loi-hee? Ka-loi-hee? Ka-loi-hee?" he piped as loudly as he could, then listened expectantly. But there was no response. Again and again and again the sweet question rang louder and louder till whispered echoes drifted from the darkening wood, but the old answers came not - in fact, they were lying snug in a new cover - what men term "brown duck." 
Two figures, plodding along the dusking road, heard Robert's last call and halted.

"By Jove!" exclaimed one, "I believe there was a bird in that old root after all, and I licked Don for digging for a chipmunk! If I was sure, I'd get down on my knees and apologize to that dog right here."

And Robert? - He slept alone for several nights, but never again did he attempt to call his lost ones. His wing quickly healed, and soon after that he fell in with fair cousins who also had known bereavement. He remained with them, sharing their joys and sorrows, delights and dangers of winter time, till April came. There was one cousin, a bright-eyed, brown-cheeked, plump-breasted Miss, who, when the flowers bloomed again, got Robert into serious trouble - but of that romance, more anon. 


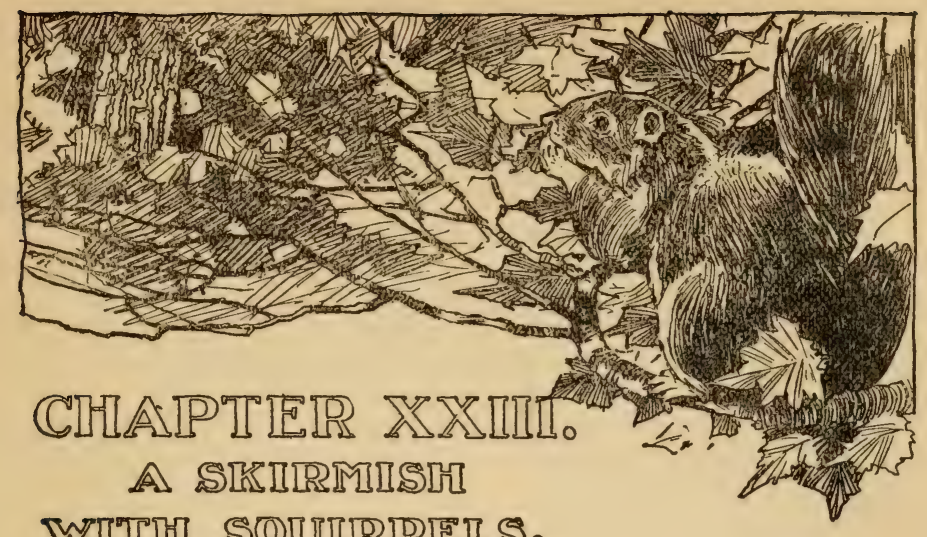

WITIT SQUIRIIELS。

OF all our four-footed game, great and small, the squirrel probably has furnished the most fun. He is the boy's first important quarry, as he is the last resource of those still fond of their bit of sport, but too old or too enfeebled for the rougher work of big game hunting. And there are many, too, in the prime of life, who do not hesitate to say that they prefer a lively day's squirrel shooting to the trailing of any member of the deer tribe. Certain it is that more men hunt squirrels than ever seek the ranges of the cervidæ.

The varieties of the squirrel family deemed worthy of pursuit in this country number four, viz. the gray squirrel, Sciurus carolinensis, the black squirrel, S. niger, the fox squirrel, which I believe scientists regard as a variety of the preceding, and the red squirrel, $S$. hudsonicus. The last-named is a nuisance, and, in order to abate a nuisance, he shall be first considered. He is a very common and remarkably officious little beast, a dangerous gossip, and an intolerable scold. Still-hunters hate him as 
they do the jay, for both quite frequently balk the hunter's effort by kicking up a row at a critical moment and thus warning every creature within earshot that man, the dreaded, is about.

The red squirrel is apt to be troublesome in other ways. He is here, there, and everywhere, about the barns and cribs, stealing grain to hide in various places, storing nuts in the attic, where he persists in running races and clattering about when you most desire to sleep, and he it is who litters your velvet lawn with countless fragments of pine and fir cones, until what was a sward of beauty looks like a swirl of scraps. All of these might be forgiven, as in doing them the creature merely follows its instincts; but there are graver charges against him.

Quick, alert, beautiful, and interesting he may be, yet he has a more than sufficiently strong dash of evil in his nature. To see him cosily hunched upon a $\operatorname{limb}$, his red banderole of a tail draped over his back while he enjoys a siesta; or when sitting upon his haunches, while his nimble fore paws handle cone, nut, or other food with astonishing dexterity, one never would suspect him of being guilty of any graver crime than petty larceny. Again, as he bounds over the lawn, or rushes along the, to all but him, precarious footing of a narrow and perhaps crooked fence top, or darts up one tree and flings himself to the next in reckless abandon, he appears the personification of the wild, the free, and the innocent. And, lastly, when he hangs head downward on a tree-bole, and coughs, scolds, and swears at you in sputtering wrath, as though the torrent of his rage ran freer in the inverted position, it is hard 
to recognize in him anything worse than a funny and quite desirable small chap.

But let us step into the orchard. The air is vibrant with the woe of robins, the wailing of catbirds, and the sympathetic outcry of a host of feathered neighbors. Some great sorrow has fallen somewhere amid the blooms and perfumes of that lovely scene. Yonder sits the sorrow-yonder upon a stub, the red rascal, turning a something in his clever paws, a something which he calmly devours, to the accompaniment of screams and futile protestations from the frantic birds. A fragment falls, and the squirrel moves away. The fragment surely is part of a blood-stained egg-shell, and its condition tells that within a few days a young bird might have been born. Above the lawn towers a sturdy pine, the top of which has been cut off to make the tree thicken. For years the flat top of that trunk has been the chosen resting-place of a pair of beautiful mourning doves. Standing near the tree, we can hear a low coughing and sputtering, not so unlike muttered profanity. Mingled with it we hear the rasp of gnashing teeth and a soft patbat-bat! after which the profanity increases. Peering upward we see, amid the dense green, one of Nature's small tragedies being played in deadly earnest.

The male dove is firmly braced above the two snowy eggs, from which the young will shortly appear if all goes well. The dove has one wing raised as a fencer holds his free hand, while the other wing is softly patting the bird's side. Sticking to the trunk a few inches below the nest is a squirrel intent upon 
a raid. He has long watched those eggs, and now his instinct tells they are as he would prefer them. He makes a sudden bounce to intimidate the dove, but the bird is brave. Quick as a flash the ready wing meets the robber's nose and with a biff-baff which suggests no trifling force. The blows almost knock the squirrel from the trunk, and he is compelled to temporarily retreat. But although his attacks have been repulsed half-a-dozen times, he is by no means done. He sidles around the trunk and attempts to carry the fortress from another point, but the wary dove has turned and is ready for him, and again the wing beats him off. "This will never do," say we, so while one runs for the gun the other keeps watch upon the robber's movements. Finally, after being driven to a proper distance from the tree, the squirrel's evil-doing is forever ended by a storm of small shot, and the valiant doves may rest in peace.

Beyond all question the red squirrel destroys a great number of the eggs of small birds, always preferring those about ready for the hatching. He also devours young birds if he can find them within a day or two after their leaving the shell. I have not known him to attack young birds after they had begun to sprout feathers, but have seen quite enough of his work during the earlier stages to warrant his destruction. I never shoot him for any other reason, as he is altogether too easy quarry to afford any sport, while his wretched little body is not worth bothering about for the table. But in the case of the gray, black, and fox squirrels things are different. A fat young one of any of these varieties is 


\section{A Skirmish with Squirrels}

indeed dainty fare - so good that it must be tasted to be properly appreciated. Nor are the old ones, when in prime condition, to be despised, as they only suffer when compared with the young, there naturally being a slight lack of tenderness and juiciness. Properly shot, dressed, and cooked, a fat squirrel is about as appetizing a thing as a man could desire.

The gray squirrel is of plump form and comparatively short bodied; he carries a fine tail which looks not unlike a beautiful gray plume. $\mathrm{He}$ is not so active as the red one, but he is perfectly at home in the trees, where as a leaper and climber he worthily represents his agile family. But, to my mind, the longer and more slender black fellow is the handsomest of all. His coat shines like satin, and his long, glossy tail adds to his apparent slenderness and truly is an adornment gracefully worn. The black squirrel is a fearless climber and a daring leaper. Strange to say, in spite of his color, an intense black all over, he is not so easily seen after he has reached the upper branches of an ordinarysized tree. He and his gray cousins are very clever at hiding. They will stick so close to a trunk, or lie so flat along a limb, that frequently they escape observation, or are only located by the tip of a tail waving in the breeze, or by the erect ears showing above their hiding-place.

The chief food of these species consists of nuts, mast, and other vegetable growths, and they are very fond of corn, especially when the grain is just passing beyond the milky stage. At this time, when at all numerous, they work no slight damage 
among the corn. I have seen half-a-dozen blacks following each other at speed along a snake fence, every squirrel carrying an ear of corn in his mouth. The plunder was borne to the shelter of near-by woods and there devoured at leisure. The squirrels would make many trips during the day, and a stroll through the corn-field would reveal ample evidence of their destructiveness. More than once I have heard farmers declare that the black raiders had destroyed fully three-fourths of what had promised to be a fair crop. This, of course, where the field lay close to a large wood.

I have used both gun and rifle in the pursuit of this game, and have enjoyed fine sport with both. But the shot-gun never should be aimed at a crouching squirrel. Sportsmanship demands that the game should be in motion when the trigger is pulled. The squirrel may be dashing over the ground, speeding along a fence top, a limb, or ascending a tree-bole, - it is all right so long as he is moving. The greatest feat of all is to stop him in the middle of a leap from one tree to another. This requires quick, accurate work, and the best of shots often fail to score a clean kill. A miss in the air and a kill with the second barrel as the squirrel races along a limb is no uncommon occurrence.

Your true squirrel hunter is full of guile. We of the old brigade played many a trick upon an unsophisticated comrade. If a squirrel was lost to sight in a thick-foliaged tree, then the wisest course was to get the other fellow to pound the trunk with a club. When a squirrel was seen upon the ground and making good time for his favorite tree, then it 
was good form to pursue, yelling to excite your friend, and, as the tree was neared, to slow up that he might out-foot you a trifle. Of course the squirrel went up the far side of the tree, and your comrade, proud of having outrun you, promptly chased around the tree to get a shot, whereupon the squirrel, being unable to count, at once shifted around to your side and offered an easy enough mark. When certain that a squirrel was hidden in the upper foliage, or upon some limb, and all pounding and shouting had failed to move him, the last resort was to fire one barrel into the densest part of the tree, and then stop the frightened game with the second. Unless the squirrel had holed, this seldom failed to start him.

For some unknown reason the supply of black squirrels varied curiously. One season they would be found in great numbers - I once drove seven up an isolated tree in a corn-field - and a year later none could be found in a day's search. The country folk had a saying that squirrels were plentiful every seven years. I will not vouch for the correctness of this, but I know that after the army of squirrels had disappeared, they were not again numerous until some years had elapsed. It was not a case of thinning out and breeding up, but a more or less regular movement across the country. I never rightly understood their migrations, but I have seen large numbers of them moving through the woods as though bound upon some well-understood mission. I have killed plenty in one bit of woods and a few days later found not one upon that ground, while the next bit of woods in the 
direction of the general movement furnished the best of sport.

The successful squirrel hunter was the envy of his youthful associates. I ranked high, probably because I had a much better gun than any of my comrades. I used to sally forth with a narrow strap buckled about my waist. When a squirrel was killed, the hind leg was slit under the tendon, the strap passed through and rebuckled. Twenty squirrels thus hung, with long tails fluttering free, made a noble fur-kilt, quite worthy of a Zulu chieftain, or Robinson Crusoe himself. When the bag was large, needless to say the proper route home was through the busiest streets. Per contra, when the bag was otherwise - just naturally too light a bag waited for darkness.

In our country were many negroes who loved "squrl" and were always hunting when that game was to be had. I once so far fell from grace as to sell seven squirrels to a negro for a nickel apiece. In town, they were worth a dime each, but one should not expect top prices in the outposts. So I sold them, and he paid me a bad quarter dollar and promised the balance later. He has never yet made good. Because of that transaction war was declared, and assuredly the brunettes had a merry time. A large percentage of them were good hunters who understood the habits of their quarry, but they were poor shots and inclined to laziness. They carried, as a rule, long-barrelled, single guns, of about fourteen or sixteen gauge, while the ammunition was in the old-fashioned horn and pouch, or, more frequently, in bottles of suitable 
size. Every one of the quaint old guns was surely the best ever made, and their owners had all sorts of names for them, such as "Wild Frank," "Long Maria," "Sweet Honey," "Reachin' Sue," and so on. A few of them, when properly loaded, would shoot fairly well, but most of them were regular old gas-pipes which flung the big shot far and wide. The negroes never attempted a running shot, but followed a squirrel until it had halted in an easy position, and then, like as not, the old gun was fired from a rest. The fact that every squirrel shot meant a dime in the hunter's pocket will explain the extreme caution exercised.

The negroes, dyed-in-the-wool pot-hunters as they were, never would give a squirrel a fair chance, and they absolutely would not hustle, so we did things to them cheerfully and without price. To roll a wad of leaves and tie it firmly with a bit of twine is a very simple matter; to cut the tail from a dead squirrel and affix it to the roll is not too laborious, considering the joys it may bring. To climb an easy tree and lash the dummy in a lofty fork possibly is hardish work, but then, where the tail swings free, the thing does look so like a squirrel. Thus we made and set the coon-trap. And if the coon did not find it, we attended to everything with a guileless simplicity which was extremely beautiful. We would meet our victim and make fair speech unto him, show him our squirrels, and gradually drift him into the danger zone. Ten to one he'd be the first to see the squirrel! And then, was it not rare sweet joy to notice how he would manœuvre us away from the prize, till in spite of our exasperating 
dawdling, we were far enough! Then it surely would be- "Wa'al, good mawnin', gemmen reckon I'se dun gwine dishyer ways fur a peeceyou'se 'tirely too spry fur de ole man dis mawnin'."

And then how we'd leg it till we could melt in behind handy trees from which to watch the old rascal hustling back for that "squrl"! He'd find it, too, all right, and before long the roar of the old gas-pipe would come to our straining ears. Sweet was that sound - sweet as the purl of running water in the desert, or a drift of music from the nearest there may be to an earthly Eden. Only the truly good can understand! And the victim would load and fire again and again while we kept careful tabs. We could picture him fumbling and sweating while trying to keep his pop eyes on the wary quarry. At every fresh roar there would be gasping snorts of bliss, while we lay on the ground and clung to roots and things, lest we be bodily transported to where such pleasure knoweth no end. And when at last the final silence fell - when we knew that shot, or powder, or caps, had run out, - wow! how good it was! - how fair the earth!- how sweet just to lie there and picture the outraged one storming away home and maybe half knocking the head off the first pickaninny that dared to ask - "Did yo" git menny squrl?"

But the cream of the squirrel shooting is enjoyed by the man who uses a light rifle of small caliber and medium power. Good shots always aimed for the head, both to add to the difficulty of the sport and to avoid spoiling meat. And be it known that a squirrel's head at forty or fifty yards is no easy 


\section{A Skirmish with Squirrels}

mark. Quite frequently an animal would be discovered lying flat upon a large limb, or sticking close to a tree-bole. In such cases it was a favorite trick to try the "barking" shot - i.e. to cause the ball to strike immediately under the squirrel. If the ball be large and correctly placed, the shock will bounce the game from its hold and send it down as dead as though the lead had pierced it. This feat of "barking" squirrels has been questioned by many doubters, but I have both seen it done and performed it so many times that I wonder that every squirrel hunter does not know all about it. I never attempted it with an arm of extremely small caliber. Vastly more difficult feats are performed daily in shooting galleries.

The best time for the rifle is during those brave brown days when nuts are ripe, and the most profitable hours are immediately after sunrise and toward sunset. Then the squirrels are busy feeding, and the true still-hunter will find much to interest him, even should he fail to bag one head of game. That all things come to him who waits is peculiarly applicable to this form of sport. There is no use in tramping noisily about. Sharp eyes and ears see and hear you long before you can locate their owners - the one reliable way is to keep still and listen.

Let us go into this wood where broad-leaved hickories, sturdy oaks, scattering chestnuts, towering elms, and fine beeches, and maples are mingled in fair proportion. Tread lightly here, 'tis squirrel-haunted ground, and yonder is an excellent seat, a mossy log well within the shadow 
of the trees. The one large pool, all that is left of the creek, gleams in the light which tells that a fine day for sport has just begun. The woods are strangely quiet. A mysterious hush prevails over all things, and silent-footed shadows creep from tree to tree. Now and then a whisper of bird-voices tinkles far away, only to quickly die and render the solemn stillness the more impressive. We wait and wait. Shafts of golden light flash through loopholes in the dome of foliage and kindle mimic fires amid the fallen leaves. We breathe the sweet woody airs, and feel within us something of the holy calm which seems to have brought the entire scene under its soothing spell.

Spat! We involuntarily start, for the sound seems to rip the stillness like a pistol-shot. Was it a large drop of water falling upon a broad leaf, or was it -?

Spat - spat! This time followed by a soft rustling of leaves in that hickory fifty feet away. The spell is broken; the witchery of woodlands loses its subtle charm, for the small sounds tell that the game is afoot. A distant barking elicits a louder, nearer reply, and soon sounds of busy life are heard from every side. A fragment of nutshell falls pattering through the leaves and strikes the ground in plain view, and small branches almost overhead rustle and sway. Presently the little rifle is pointed upward, then a sharp report, a momentary agitation among the branches, a succession of crashes, a heavy thump upon the ground - and there he lies. He is a fat fellow, but a red streak in his glossy fur shows where the ball passed through his 


\section{A Skirmisb with Squirrels}

neck, an inch from the spot aimed at. But the view was none too clear and no meat is spoiled. Rustling of leaves and branches are heard in several directions, for the rifle, though small, has a spiteful tongue, and the game has moved a bit. In the distance a swift shape is traversing a fallen tree, but we had better remain quietly where we are, as another squirrel may be hiding above. Moments pass and at last a leaf rustles. There! See-upon that long limb stretching toward the maples. With high-arched back and head in bold relief, he pauses to measure the leap. The other rifle comes into position, dwells a moment, then again the fatal crack. The squirrel makes a convulsive spring in the direction it had intended taking, but it appears to halt in mid air; then it comes whizzing down, turning over and over as it falls. The shock was instant death.

And so it goes on through three pleasant hours. We change position now and then, but at last the word has been passed around to all the furry people, and chances become few and far between. Our last squirrel is espied running along the border-fence, and we watch him closely. He halts, hesitates, then drops upon the ground, where for a time he sits erect to take observations. Satisfied that the coast is clear, he moves toward the pool in a series of hesitating leaps, interrupted by many cautious pauses for examination of the surroundings. He at last leaps to a small snag projecting a few inches above the water. He forms a pretty picture as he sits with ebon plume curving above his back, and his inverted image as sharply defined below. 
It is indeed a fair chance at forty yards; yet at the sound of the rifle a cascade of white water leaps into the air, and the thoroughly frightened squirrel darts to the nearest tree. In his haste he has chosen an isolated shelter, far beyond leaping distance from its nearest neighbor. And now for the wind-up. The tree is healthy, tall, free from holes, and the game's sole chance is to climb to the loftiest twig that will bear his weight. There he is, at the very top, swaying to and fro upon a slender switch. His fluttering tail adds to the difficulty of the mark. Five times the small rifles hail him, the buzzing lead almost ruffling his fur. Yet he gives no sign. He has done his best in such a tree; this his instinct tells him, and all he can do is hang on and wait. It is not for long. The sixth shot is better timed. A small black ball starts earthward, gaining velocity and bulk as it comes, and strikes the ground with a sounding thump, then rebounds a yard into the air. Now let us be off for breakfast, for the cup of coffee at starting has long since lost its influence. We may try again toward evening, for there are plenty of squirrels left. 


\section{CILAIPTEIR ISISIV. TUIRIRIEY-WITIT TILANIKSGIVING}

THE turkey is wondrous toothsome, whether it be a choice bird from the fattening pen or one of those kings of the feathered race, a grand wild fellow, slain perhaps after a deal of toil and trouble in his native haunt - some Southern river bottom, Western scrub, or lonely Canadian forest. The price paid by the epicure for his wild bird would doubtless purchase provisions enough to feast a family of the breadwinning class on excellent fare for an entire week, so the toilers must needs be content with a less aristocratic fowl than Meleagris gallopavo.

Year by year the wild birds are decreasing in number, and the day is not far distant when the turkey will no longer exist in the wild state save in a few favored portions of the South and Southwest. Easily trapped and always valuable, either for the market or for home consumption, it is hardly surprising that the birds have been eagerly sought and remorselessly slain wherever found, and were it not for their keen sight and swift and enduring running powers they would long ago have been exterminated in certain accessible forests where a few yet find a home.

But while the turkey is one of the easiest birds to trap, he is no fool to follow with rifle or gun 
in his forest ranges. Wild and shy to a degree, keen sighted, quick eared, swift of foot, and strong of wing when needs be, he is also sharply suspicious of a man on foot, and quite as difficult to "still-hunt" as a deer. Generally ranging in heavy forest, and within easy reach of tangled scrub or other baffling cover, no sooner does he suspect danger than his long legs bear him swiftly to the densest growth he can find, through which a man may track him for hours without either obtaining a shot or forcing him to take wing, and frequently the bird will not even be seen.

The principles of good sportsmanship admit of the wild turkey being taken by several methods. One of these is shooting the birds when roosting in tall timber at night. All that is necessary is first to locate the "roost," then to steal upon the unsuspecting game and shoot as many as possible before the turkeys realize what is going on and leave the unhealthy neighborhood. A second method is "calling," or "yelping." The sportsman uses a bone from a turkey's wing as a "caller," and by sucking air through this bone in the proper fashion an exact imitation of the "yelp" of the bird is produced. An ordinary clay pipe also makes an excellent caller. This method may be followed with deadly effect either after a flock has been scattered or, as is done in the South, while the gobblers are "strutting," in which case a good imitation of the cry of a lovelorn hen will lure the male to his destruction.

Still another method, the most dashing and exciting sport of all, is coursing the birds with greyhounds. 
This demands an open country, and is, I believe, only attempted on the plains of the far South and Southwest. For this sport a man must be a good horseman and be well mounted, as the going is fast and free and the ground covered frequently dangerous. The turkeys are found feeding in the open; the dogs are slipped, and when the birds take wing, horse and hounds follow the selected victim as fast as they can lay foot to the ground. The turkey flies straight, and though its first flight may be half a mile or more, it has not time to recover from the unusual exertion ere the fleet dogs again compel it to take wing. It may rise two or three times, but its strength is soon spent, and unless it can reach heavy cover the dogs pull it down, the horseman meanwhile following the chase in the best way that he can.

Yet another method, and a thoroughly sportsmanlike one, is tracking or "still-hunting." The best time for this is immediately after a light fall of snow, when all sign is fresh, and the contest becomes a fair test of hunter's craft against cunning and endurance. The still-hunter will earn his bird, no matter whether he carry a rifle and kill his game at long range, or a shot-gun and kill it flying, after he has fairly tramped it to a standstill, forced it from sheer weariness to squat and hide, and then flushed it from cover by his close approach. Tracking turkeys in the kind of ground they usually favor is emphatically hard work, and the tracker will be led, perhaps, for mile after mile through just the sort of cover that tempts one to halt and "talk the bark off a tree" now and then. I have many times followed 
turkeys - sometimes on the tracks, sometimes by guesswork - for an entire day and never had a chance at a bird.

One fall, that now has many leaves upon its grave, I decided to take a run into Essex Woods and try for a good gobbler, though a plump hen would not have been beneath attention. It had rained hard for several days, then the cold came, and with it a slight fall of snow, though hardly sufficient for good tracking. It was an extremely sharp, clear morning when I left a comfortable farm-house some miles west of Essex Centre, and with Winchester on shoulder started for the great silent stretch of woods which extended for miles in every direction. I knew that the fowl were in those woods, and was fully resolved to have one before night, but soon learned that it wasn't a good day for turkey.

Every hollow between the thick-standing oaks, maples, and elms had been filled to o'erflowing by the rains, and now every pool was covered with an inchthick coat of ice - just thick enough not to bear one hundred and eighty pounds. Every twig and frozen leaf under foot crushed like glass, and under such conditions I was about as likely to get within shot of a turkey as I was to tree a Bengal tiger up one of the big elms. There was nothing for it but to acknowledge a balk, and I retreated to the railroad, the track being about the only place where dry walking was possible. After infinite difficulty, aided by a couple of rails from the snake-fence, I managed to safely cross the deep ditch between the woods and the track, and so reached safe footing.

It was an exasperating situation. Straight as a 


\section{Turkey - with Thanksgiving}

rule, east and west, stretched the narrow road-bed, with its two shining rails; on either side were broad ditches containing water perhaps five feet deep, coated with treacherous ice, and I thus had a promenade over one hundred miles long, but only about fifteen feet wide. A tempting shooting ground, truly! A fellow might get rail-birds on it or shoot off a few ties to fill in time, but it was not very exhilarating. There was nothing to do until the evening train came along to take me home again. Nothing but a heavy frost, followed by snow, would make still-hunting possible, and there were no indications of snow.

For want of something better to do I strolled a couple of miles along the track, and by so doing made a discovery which changed the aspect of affairs. A car laden with shelled corn must have passed some days before and had a hole in it, for a streak of yellow grain extended for some three hundred yards beside the rails. Near my end of the corn was a culvert through which, under ordinary conditions, cattle could pass. But it was now filled to within a couple of feet of the top with water, like the ditches coated with ice.

Everywhere within a short distance of this culvert were traces of wild turkeys, and it was an easy task to read the possibilities. The birds had discovered the trail of grain and had been feeding on it for two or three days. The rains had drowned out their feeding grounds in the woods, and they would be sure to return to the corn day after day until the last grain was eaten. It was simply a question of close hiding, more or less of the long agony of hope 
deferred, and then - and then a turkey would be mine! I fairly grinned over that layout.

But where to hide? Not an available point offered; the track was as bare as the rifle barrel, and the road-bed was elevated so much above the level of the woods that it could not be properly commanded, except I climbed a tree, which would be altogether unsuitable.

The culvert!

Yes, the culvert; but the ice would barely hold, thought I. However, a look at it would do no harm. I carefully tested it, and found that owing to its narrowness and the grip the timber walls afforded the ice it would just bear me. Happy thought; a board off yon gate broken in two and cushioned with a layer of dry grass and stuff would make a comfortable resting-place, and spread its pressure on the ice sufficiently to make all safe. The board was soon secured, placed in two halves on the ice, and padded with handfuls of withered herbage, and I was all ready for business. Sitting upon my boards, I could just comfortably raise my eyes above the track, and if I got upon my knees, the edge of the culvert afforded a dead rest for my elbow, and I felt I couldn't miss a turkey at one hundred yards if I tried. It was superb, and I grinned some more. This was just the luckiest, laziest turkey-shoot on record.

For some time I sat there, closely watching the track and the woods upon either side. It was tedious, cold work enough, and in due time I grew weary and cramped from the confined position and varied things by creeping out of my shelter and having a 
bit of a dance to stir sluggish blood. Just as I thought of again going to cover, a black object moved in the woods, perhaps two hundred yards away. No need for a second glance; it could only be a turkey; and as speedily as possible I crawled back into the culvert, and with my head close to the rail waited further developments. Moments dragged past, and at last one bird appeared on the track, a good three hundred yards off, and was presently followed by another, and another, and yet others, until nine stately fowl were in plain view. They soon turned in my direction, and moved forward.

It was now a "regular cinch," and I hugged my head closer to the rail and glared down the track at those turkeys with a burning intentness that melted what little snow there was near my face. They were coming - they were bound to feed right up to my stand if I chose to let 'em. I would kill the big gobbler, and then take chances for another, run or fly. No, I wouldn't either. I would be silent and wary as a lynx and let them feed good and close, and wait for the big fellow and another to get in line and straighten out a brace of them at the one shot.

They came steadily on. They were now only about two hundred yards away, and advancing in Indian file. Nearer and nearer they came, and I changed my purpose. Two in line were not enough for such an opportunity. I would draw a dead bead on the big fellow and hold on him till three were in range. Yes, that would be better. Still they advanced, and only one hundred and fifty yards separated them from their doom. Now they quick- 
ened their movements and advanced rapidly for some distance. They had reached the trail of corn, and they crowded close bunched over the first scattered grains. Once again my resolution wavered. Hang it all! it was just as easy to get four in line a ball at short range would stiffen four of them easy enough. I must have four.

Step by step, yard by yard, they came on, ever drawing nearer and nearer to the certain death that waited to claim its four. Every once in a while they would all bunch together, and as they did this at a range of about one hundred yards my modesty wavered again.

Could it be possible to drive a ball through five of them in line? Such a record - such a shot to describe to the boys! Five grand wild turkeys at one lick! I was just fairly entertaining the five notion, when an ominous click sounded along the rails - that mysterious click which announces the coming of a train.

"Click - tuck - click!" There was no mistake. It must be a freight, for no express was due at that hour.

"Click - tuck-lick - click!" The mysterious message had reached the turkeys' ears, too, and they lifted their heads on high and stood motionless. I breathed hard at the change of luck, and considered what I should do. My mind was almost made up to shoot at once, for the rails were now clicking merrily, when, like a saving clause, the thought occurred to me that they heard trains passing many times every day, and probably would merely retreat into the woods for a short distance 


\section{Turkey —with Thanksgiving}

and return when all became still. They had certainly been disturbed in this fashion more than once before.

These reflections were rather comforting, and I resolved to just lie low where I was and let the train thunder above my head. I was perfectly safe and could get my five birds just as well as not when they came back. I took a peep eastward, and there, sure enough, was my train coming along at a great rate. Looking again in the direction of the turkeys, I saw the last two or three trot into cover. They undoubtedly were not seriously alarmed and would resume feeding in half an hour.

There I lay, close as possible, and in a moment the train thundered overhead. Though I knew I was perfectly secure, I fairly shuddered as the first couple of pairs of wheels passed so close to my head. Heavens! what a jar and row it made! Would it never draw its frightful length across that culvert? At last, when I was almost deafened, a blessed pause in the uproar brought relief. A hollow "plunkplunk" of the last pair of wheels announced the complete passage of the conductor's red van, and I made a move to rise.

There was a faint, squeaking, grinding noise, a squirt of ice-cold water, then a frightful crash and splash, and I gave an involuntary imitation of a young man falling through a glass skylight and fetching up in a well. The vibration of the train had loosened the ice from the walls of the culvert, and the whole business broke into fragments, and I was in it!

I didn't wait to touch bottom, but pawed and 
sputtered and floundered round with the bits of boards and the roots and the grass and the ice, and clambered out just as quick as the Lord would allow. Then I swore at the train and the turkeys and the culvert and the ice and the water and the smart Aleck who planned the ambushment, and the rifle for being in that zeroed fool-trap yet; then, in spite of chattering teeth and trembling limbs, I laughed - I had to laugh.

But the worst of it was that I had to go in again, and also go clean under water for a horrible quarter minute to recover the rifle, after I had located it with my foot; for no consideration would have induced me to leave it there. Then I clambered out once more, and groaning and shivering and shedding water every jump, ran and walked and staggered the best way I could to the farm-house, where I had a hot drink and a sleep in thick blankets while my clothes were thoroughly dried. That was finally accomplished late in the afternoon, but whether or no it is possible to drive a ball through five turkeys in line - I just dinna ken! 


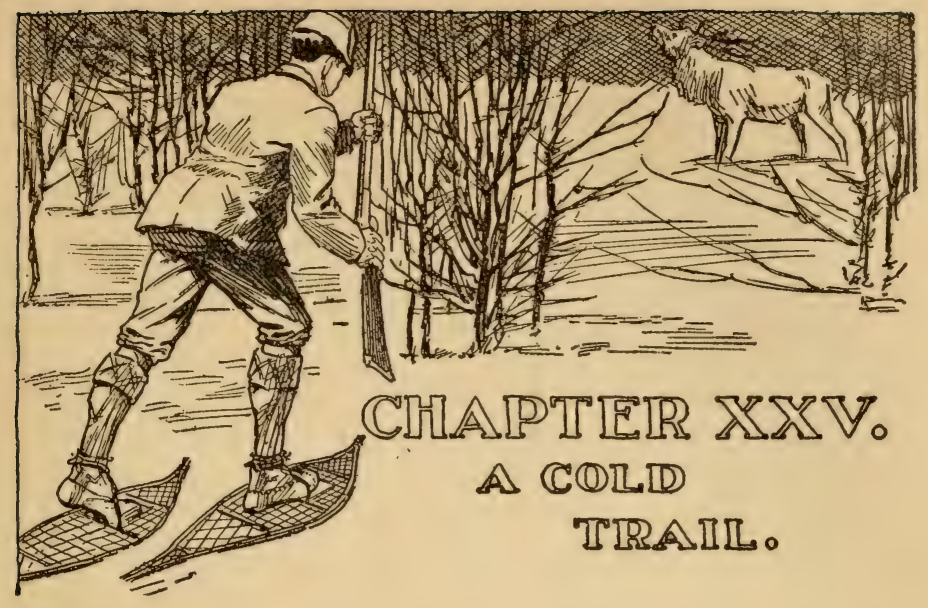

Although the "king of American game" unquestionably is that grim ruffian, the grizzly bear (Ursus horribilis), yet he is by no means the most desirable of our big game as an object of pursuit. To the average sportsman the chase of the grizzly would be about as enjoyable a proceeding as a severe day's toil at hod-carrying followed by a frightful nightmare. Ursus horribilis is bad medicine if tackled in his mountain domain, and only the keenest of Nimrods ever penetrate to the lonely wilds over which he rules supreme. True, quite a number of sportsmen are possessed of grizzly skins and proudly display them as trophies of their prowess afield; but, if the whole truth were known, in many cases we would find that some Western bravo, or professional or Indian hunter, actually slew the bears from whence the trophies came. United States currency bags more bearskins in Western wilds than do all the gentlemen sportsmen's rifles put together.

The same might truthfully be said concerning the obtaining of many heads of elk, moose, caribou, 
mountain sheep and goat; for many more men show one or other of these as trophy of their own winning than ever bore rifle through the lonely ranges of moose and caribou, or climbed to the elk's strongholds or the cloud-swept pasturage of sheep and goat.

That there is, however, a stanch fraternity of good men and true - iron-nerved, hardy fellows - who find the purest enjoyment of their lives in the pursuit of big game, goes without saying. Such men love the rifle and the difficulties and dangers ever attendant upon its use on legitimate game. They penetrate to the uttermost parts of the earth to gratify their thirst for adventure; they toil like galley-slaves, endure pain, pestilence, and famine, battle and possibly sudden death - in fine, willingly brave all those evils which stay-at-homes pray to be delivered from. This love of adventure and dangerous sport is beyond doubt a valuable trait in our national character. It encourages self-reliance, courage, judgment, and rugged health, helps to build up a race of manly men, and very frequently contributes invaluable information concerning the resources, etc., of littleknown regions; for the successful hunter of big game must be a close observer, and as often as not he is a man of influence when at home, whose statements are respected whenever he describes whither his quest of adventure led him and what he saw by the way. Something of the spirit of the Viking, of Columbus, Cartier, Standish, of the many iron men of sea and land whose names glitter like stars through the sombre clouds of early American history, lingers with us yet, and certainly will not die before the final 
disappearance of our big game. Yet, despite the fierce excitement and triumph of facing and slaying dangerous cat or plantigrade, it is questionable if there is not more genuine sport to be found in the chase of such animals as the greater cervide, which seldom inflict any serious injury upon their pursuer.

Possessing the strength of two horses and the malevolence of two devils, grizzly old Ephraim is a dangerous antagonist, ready to maul all intruders at the shortest notice; but his pursuit seldom or never calls forth the exercise of the finer principles of huntercraft. While an encounter with him may thoroughly test human courage and nerve, he does not fear man sufficiently to demand either practised trailing or perfected woodcraft in the man who desires a close view of his rusty hide. Though he generally avoids the encounter, and not infrequently actually flees from it, he does not possess that instinctive dread of man which characterizes the whole deer tribe; nor does he, as the latter do, use any art to conceal his trail or himself. Should he run, 'twill not be far; rather will he go shambling off to his stronghold in a defiant sort of style, as though his discretion and his valor were engaged in a doubtful struggle for supremacy.

A rash move on the part of his enemy, one touch of lead, or the ping of a harmless ball past him, may rouse the lightly shackled devil in him - and then for war!

But when a moose, elk, caribou, or even deer or turkey is the object of the sportsman's quest, how different are the conditions and how much more vague the possibilities! Keen eyes, and keener 
nostrils and ears, ever watch the backward trail, or sift the telltale air for the faintest evidence of danger; cunning brains, quickened by an irresistible dread of man, evolve schemes of doubling and dodging and crafty concealment; and strong, fleet limbs, that can laugh at miles of heavy going, are ever ready to bear their owner far from the dreaded pursuer creeping through the cover.

More often than not, the sportsman's toil is all in vain. After exercising the perfection of his craft and calling forth all his reserves of skill gained in years of experience, after enduring for hours the long agony of hope deferred, at last, when the hard-earned opportunity is almost grasped, some totally unexpected combination of " hard luck" — a stumble, a misstep, a sudden shifting of the breeze, the deflection of a bullet by an unseen twig, or one or other of the many things which can mar a still-hunter's success intervenes, and naught perhaps remains but a toilsome tramp of miles before camp is reached.

Nor is the chase of such quarry altogether devoid of personal danger. The cervide may be timid animals enough as a general rule, but they can fight like demons under certain conditions, and when fairly at bay, their strength and agility make them exceedingly dangerous. Even a male Virginia deer, if wounded and thoroughly angered, is no mean antagonist for a strong man to face. His sharp fore feet cut like daggers, and one of his lightninglike blows, fairly planted, would probably maim or mark a man for life. A bull moose or caribou, if wounded or too hard pressed in deep snow, will fight in short order, and woe betide the man who 


\section{A Cold Trail}

fails to promptly reach a friendly tree if he does not drop the charging bull in his tracks!

Grizzly Ephraim himself might not maul a man worse than would either bull moose or caribou, if the enraged beast ever got at close quarters with his foe. The first to take effect of the shower of whizzing blows sure to be delivered by the fore limbs would knock the sporting instinct so far out of a man that he wouldn't recognize it, should it ever happen to find its way back. And a bull elk - but any one who has followed an elk knows its strength and quickness, and one glance at the tremendous forest of dagger-pointed tines upon Milord's shapely head will suggest its possibilities.

Aside from the somewhat remote chance of being attacked by one of these animals, the still-hunter, being alone, is continually exposed to dangers of falls among rough rocks, broken limbs, sprained ankles, and also of getting thoroughly well lost in a wilderness, where he might not meet a man in six months. In fact, still-hunting moose, elk, or caribou is emphatically hard work. Its great charm lies in the fact that it is a fair test of accomplished woodcraft and human endurance versus animal powers of a very high order, aided by almost tireless strength and speed.

The caribou is a keen-nosed, shy, fast-trotting, sturdy fellow, and right worthy game for any man's rifle. Two varieties of this species - the woodland and the barren-ground caribou - are best known to sportsmen. The woodland variety is found in Maine and certain extreme northern portions of the United States, notably about the head waters of the Missis- 
sippi River and in the extreme north of Idaho. The barren-ground caribou does not generally range so far south as the international boundary. In Canada caribou are much more distributed. They are very plentiful in Newfoundland, scarce in Nova Scotia, more numerous in New Brunswick, abundant in Quebec and Labrador, and fair numbers of them haunt the wilds of northern Ontario (especially the north shore of Lake Superior) and portions of Manitoba. In British Columbia they abound among the mountains, and not infrequently great herds are seen defiling from some cañon or moving down some mountain side in Indian file, and looking at a distance like a pack-train.

The best caribou shooting may be had in Newfoundland and British Columbia, but Quebec and north Ontario yet offer good sport to those who like roughing it.

During one winter I was temporarily located at a point on the magnificent north shore of Lake Superior, my companion being a half-breed hunter who bore a resonant Indian title too long for insertion in these pages. When he wanted to travel light, he bore the name of "Jo," which will answer for the present. It was cold up there in the icy breath of the Great Inland Sea, but we were snug enough in an old railway construction log camp, and had fairly good sport with grouse, filling up time attending to Jo's lines of traps. Between Superior and the "height of land" is a perfect network of lakes and streams, large and small; the country is very rough and rocky, varied with great barrens, muskegs, and beaver-meadows. Vast portions are densely forested, 
and others carry only ghostly, scattered "rampikes," showing where fires have swept. Our headquarters was the log camp referred to, but we had a temporary camp at the end of a line of traps some ten miles inland, near the head of a chain of small lakes, famous in the annals of the fur trade. From it, westward, extended an immense barren for mile after mile, bounded by a gray-blue wall of forest.

One night, while we were at the little camp, a heavy fall of snow re-dressed the hard-featured landscape, and Jo and I fell to discussing the chance for caribou. About daylight we turned out, and Jo stood for a few moments reading the sky and sweeping the barren with those marvellous aboriginal eyes of his, which could count a band of animals farther than I could see them. Presently he grunted softly and exclaimed :-

"Dar um car'boo!" and pointed westward.

I looked long and earnestly, and at last made out a distant object moving slowly over the snowy barren. Getting the glass, I focussed on it and discovered that it was indeed a caribou - a lone bull evidently, as no more could be found.

After hurriedly feeding, we stuffed our pockets with bread and meat, felt that matches, pipes, and "baccy" were in their places, donned our snowshoes, and started in the direction of our vanished game.

"Car'boo all right; feed day on moss. Bymeby find um more car'boo," said Jo, and I guessed that he liked the prospect.

It was a cold, gray day; a sharp breeze blew directly across the barren, and now and then a few 
snowflakes sifted down, hinting of another downfall, though there was already more snow than we wanted. But there was little danger of anything serious, and we didn't trouble about the weather. After tramping for about three miles Jo discovered the tracks of the caribou, but the beast itself was not in sight.

Jo decided that he would work across the barren in case the game had doubled on its course, and leave me to follow the track. "Me go 'cross, look 'long um tree. You run track, bymeby mebbe you find um car'boo," and he waved his hand, indicating that he would cross and then scout along the woods on the farther side.

I moved rapidly, while Jo was in the open, being anxious to get far enough in advance of him to forestall all possibility of his wind reaching the game before I got within range. I had followed the track until it was nearly noon, keeping a sharp lookout ahead, before I caught a glimpse of the bull browsing near the edge of the woods. A long look through the glass told me that he was a magnificent specimen, bearing a particularly fine set of antlers, and that he was feeding near cover which promised a comparatively easy approach to within certain range.

To obtain this splendid trophy was my firm resolve, if patient, skilful "creeping" counted for anything. Working carefully well to leeward, the shelter of the dense timber was at last safely gained at a point some half mile from the game. I had already put in a lot of hard work, and was half wearied, but the golden prospect sustained me. 
Once safe in cover, the shoes were removed, and, gliding, stealing, flitting shadow-like from tree to tree, now crouching in the line of a boulder, now crawling and wriggling painfully over a snowy open patch of moss, I at last gained the edge of the timber within a hundred and seventy-five yards of my meat.'

He was standing with his rump to me, and his nose occasionally sought the moss, only to be raised in a moment and thrust into the wind while the gentleman chewed a mouthful. About halfway between us was a goodly clump of brush, overgrowing some scattered boulders, while the space between my shelter and the brush was filled with little hummocks and hollows, showing where the low growth, moss, etc., upheld the snow. If I once gained the brush, and nerves kept steady, he should drop in his tracks.

I hesitated for a moment between waiting for a broadside shot from where I was, or attempting to crawl to the brush, then got down on hands and knees and began the difficult journey. The hummocks were smaller and hollows shallower when reached than they had seemed, and when halfway across the dangerous space it became a question of wriggling along à-la-serpent. In this position the caribou was invisible, but I had faith in the wind, and was wriggling doggedly forward, when from a clump of moss not twenty feet from my nose a grouse walked forth, clucking softly to itself in regard to my probable business.

Here was a pretty position. Of course I didn't dare flush the grouse, for fear of alarming the caribou, 
and for long, agonizing moments I lay there in the snow staring at that infernal bird, while it eyed me dreamily, and chuckled in an exasperatingly commiserating fashion, until the cramp-knot in my leg grew hard as a base-ball, and I fumed and raged and groaned inwardly. At last the fool-bird satisfied its curiosity and trotted demurely away, and, when it had got to a safe distance, I straightened my cramp and wriggled on to the tuft whence the grouse had come.

Inch by inch I raised my head, until a clear view was possible of the bull's feeding ground - he had vanished as though the earth had swallowed him! Hastily glancing up the barren, I caught sight of him walking smartly along, a good four hundred yards away. He was not alarmed; he had neither heard, seen, nor winded me. He had merely decided to move along. It was one of those maddening brute whims that checkmate the still-hunter. I examined the rifle cover to make sure that all was right. Then, after a good stretch to ease my cramped muscles, I watched the bull and nursed my hard luck.

But chance favored me in the next move. The caribou, after going about half a mile, turned across the barren and headed for the timber on the farther side, at the same time edging slightly in my direction. This course kept him well to windward, and when he finally approached the distant cover, I again started for him.

It was a long, hard task to cross the barren in a crouching position, but finally I managed to get behind him safely and followed the track. I was 


\section{A Cold Trail}

now very tired, for the shoeing was heavy, but the chase was leading homeward. I was mad all through and game to fight it out on that line till darkness came. Presently it began to snow, and in half an hour the air was thick with soft-falling flakes. This was in my favor, save that I sometimes lost sight of the bull, only to rediscover him walking steadily along, headed direct for camp. My only hope was that he might halt to feed. $\mathrm{He}$ was going about as fast as I could, and so for two good hours we reeled off the miles at an exercising gait.

At last the snow almost ceased, but the air was darkening fast, and I guessed we must be within short distance of camp. While I was endeavoring to figure out my exact whereabouts, the bull halted in an open space, bordered on my side by clumps of good cover, and began to feed. My weariness was forgotten in a moment; luck had turned my way at last, for he was in perhaps the best position for me that he could have chosen on the whole barren.

Sneaking rapidly on as far as was safe, I once again doffed shoes and got down on hands and knees and crawled, and crawled, and crawled, until the cover was gained, and my victim stood broadside on, not eighty yards away. He was feeding, and had no more idea that I was near than I had of shouting. Carefully I rose to my knees and waited one moment to pull myself together for the shot that must needs decide the matter. A last glance at the distance, and at the sight to make certain that it was at the lowest notch, and I thought to myself :-

"Now, my son, I'll just settle for all this tramp. 
If I don't drop you - " "Whang!" The roar of a rifle sounded from a clump to my left, a stream of fiery smoke shot from the brush, the bull gave a tremendous lunge forward and went down in a heap.

For some seconds I was petrified with amazement; then leaped to my feet, prepared to do I hardly knew what. From the brush near by rose a lank figure, a coppery face peered forth, and an unmistakable voice muttered, "Gess I down um car'boo!"

"Jo! You smoke-tanned idiot, I've a good notion to put a ball through you!"

Jo started with as much surprise as his kind ever show; then his broad mouth spread in a diabolical grin, for he guessed every incident of the story.

"Me no see you. See um car'boo cum long. Me hide, tink mebbe kill um car'boo. You lynx, you creep-creep - me no tink you chase um car'boo." And that was all the comfort I got, outside of the head and feet, which were all I wanted of the bull.

Later in the evening, when I told Jo of the allday chase and where I had been, he grunted and said: "Chase um car'boo berry long time - twentoo mile dat way an back."

"Yes, and I crawled quarter of it, confound you!"

"Um, dat so? Me go two, three, four mile, look at trap, den run back to mend shoe. Me stop by fire, bymeby get um car'boo."

"Yes, after I chase him twenty-two miles for you, you old squaw!" 
A chuckling grunt proved that Jo realized the humor of the thing in full, and the way his eyes twinkled and the wrinkles curved round his silent mouth almost threw me into fits, for there was no use in kicking against fate. 


\section{CHLAPTIER KXVI. \\ TrLE WUITTE WOLIF \\ OIF ITIIE $\mathbb{N O R T R I ~}$}

WE were in the caribou country. Far north, wrapped in his white shroud, lay Mistassini sleeping through the long white silence until Wa-Wa called him. Nearer, to the left, lay the Big Flat Water drowsing under a pallid coverlid a fathom thick. Over all sprang an arch of mysterious gray, that seemed to draw in and narrow slowly, silently, steadily, while we looked. Far as we could see, stretching in one soundless cordon until they dwindled to mere mounds in the distance, stood what had been sturdy conifers. Now they were tents - drear domes of death they seemed, pitched there by the army of the Arctic for a bitter bivouac. We stood before the small cabin and looked eastward. No sign of the sun, although he had been up an hour. Somewhere behind the sad gray veil he was shining with the wonderful brilliancy of the North, but that day he would cast no velvet shadows for us.

"Well, wot ye tink?" inquired Jo.

I hardly knew what to say. Something in the feel of the air, in the pervading grayness, counselled caution, yet here was the last day of my leave, and as yet the twelve-gauge had not spoken to the game I particularly wanted, - the ptarmigan in its full winter plumage. 
Jo waited with all the patience of the Indian cross which browned his skin and blackened his long, straight hair. What he thought of the prospect did not matter, nor would he tell - his kind never do until after it is all over. All he wanted out of me was a decision one way or the other. If I said "Go," he would lead away north without a word of comment; if I said "No," he would merely go into the cabin and lie and smoke. Perhaps toward night he might say, "We'd best gone." He was a picturesque-looking tramp in the gay garb of the lumberman. How much he had on underneath I could only guess, but it was quite enough to spoil the outline of what was naturally a beautiful, lean, strong figure. On his head, six feet from his heels, was a shocking bad hat, a black felt he had picked up somewhere. Bad as it was, it stuck on and shaded his eyes. His long hair protected his ears and that was sufficient. Only his small, narrow feet were Indian. They were hidden in as pretty a pair of moccasins as I had seen. But a glance at his face told the story. Somewhere not far back in Jo's pedigree lay the cross, and in this case the blending of the blood of the indomitable voyageur with that of the redskin had produced a grand man, - game, untiring, wizard of woodland, a child till the hot blood was roused; an Indian when the devil was unchained.

For a few moments I hesitated. If I could only translate the flash of the wonderful aboriginal eyes or guess what lay behind the mystical bronze mask, - but that was impossible. Once more my eyes turned northward. The grayness seemed a trifle 
paler, and a puff of air, keen as if from the very Pole, met me. "Looks like snow - too cold to snow," I muttered; then added louder:-

"We'll try it."

The black eyes twinkled an instant with an indescribable flash, then he turned into the cabin. As I followed I heard him give utterance to a peculiar low grunt, which might have meant anything or nothing. I would have given something to have been able to translate it, for beyond question my decision had raised or lowered his estimation of my woodcraft and general qualifications. I acquired wisdom later.

Within five minutes we were ready. Jo had carefully watched the flask, sandwich, shells, and tobacco go into my pockets, and again had grunted softly when I examined my matchbox. Then, without a word, he led the way on the creaking, netted shoes which alone rendered walking a possibility. He was a mighty pace-maker. Snow-shoeing is the hardest of hard work, and Jo certainly showed me all there was in it. Before half a mile had been covered he had me fumbling with mittenless hand at the unruly button at my throat, and by the time a mile lay behind my forehead was damp in spite of an air that nipped like a mink-trap. At length we reached the edge of a tongue of fir-woods, where Jo paused. Before spread a mile-broad open, where some old fire had bitten to the bone. In summer this was an artistic expanse of lichened rocks, with low, lean scrub between; now it spread like a frozen sea, with stiffened billows half buried in purest snow. For minutes he stood, while his eyes scanned every 
yard of white from his feet to the irregular skyline.

"Mebbe car'boo," he muttered, as he rolled his eyes toward a slight depression which I should have passed by. Then he stooped and thrust his hand into the snow.

"Big bull — old," was all the comment he made as he straightened and again led the way.

Evidently the open had no attraction for him, for he swung off to the right, keeping along the edge of the cover. Here what breeze there was had full sweep, and it nipped keenly at the nose, cheeks, and chin. Already my heavy mustache was burdened with ice, and a certain caution about breathing had developed. But Jo did not appear to bother about trifles like that, although his bronzed face did show a warmer color. His steady, remorseless gait never changed, and the rear view of him suggested that he was apt to go on till spring. Nor was the shoeing easy. The old snow-shoer will understand what the conditions meant, and while I was in very fair form and no mean performer across country, I thoroughly realized that there was an iron man ahead. This, too, while merely following a pace-maker - a very different matter from leading.

It was perhaps an hour later when he halted and blew a great cloud of steam from his lips. I understood, and at once produced the flask and poured him a fair measure into the metal cup. The good stuff fairly fell into him - but an Indian's an Indian.

"You no take?" he queried, while a surprised expression flitted across the chasm which had entombed his share. 
"Bad for eyes - snow bad enough now," I retorted, as I put away the flask, for Jo's eyes seemed to say that if I didn't intend to take any, he might as well have my share. But that was not in order.

Instead of moving forward, he smiled and pointed at the snow. "Thur," was all he said.

I looked and saw one, two, three - a dozen tiny trails, as though elfin snow-shoers had passed that way. They were queer little tracks, roundish, indistinct, running in single lines, the rear rim of one almost overlapping the fore rim of another. Never had I beheld the like. By the size of them their makers should have been of considerable weight, yet they barely dented the snow. Their arrangement was grouse-like, and in a moment I had it. Nothing but the wonderful show-shoe foot of the ptarmigan could leave a trail like that.

"Snow-grouse - white - eh?" I asked.

He nodded.

"Fresh - where'bouts?" I continued.

"Look - look lot," he replied.

A twinkle in his eye warned me that I had better be mighty careful, and I felt certain he had already seen the birds. But where? Standing perfectly still, I first scanned the snowy trees. Nothing there. Then, remembering the ways of the quail and the many times I had detected birds upon the ground ahead of the dogs, I began a close scrutiny of the snow a few yards ahead. Presently a shiny ebon point caught my eye, then a dull point equally black - then, as if my eyes had suddenly become properly focussed, I made out the soft, white, pigeonlike form of a ptarmigan crouched upon the snow. 
Then another and another showed, until I could plainly see seven birds in all. They were from about eight to ten yards distant, and as motionless as so many snowballs, which they greatly resembled.

My right hand rose slowly to my frosted chops, teeth seized the point of the heavy mitten, and the bare hand slipped forth and closed upon the grip. In five seconds the steaming hand felt the nip of the air and the apparently red-hot touch of metal. Then I let the mitten fall from my mouth.

Purr-r-whir-r-bur-r! The white forms rose something like quail, but lacking the hollow thunder and impetuous dash of the brave brown bird. Even as the gun leaped to shoulder I realized that the white ghosts were not going so fast, but true to old quail training, the trigger finger worked as though dense cover was only two yards instead of a mile away. The first bird stopped - shattered - within twentyfive yards, and the second not more than five yards beyond its mate. Jo grunted like a bull moose, then dashed ahead, and I chuckled as I remembered that this was the first time he had seen a "squawgun " in action. But, instead of going direct to the birds, he chased on with long strides to a point sixty odd yards beyond, and stooping, picked up a third ptarmigan which had managed to get into line with the second. This he triumphantly retrieved. Beautiful, snowy things they were, with the cold, white sparks powdering their spotless covering and sticking to the hair-like texture of the poor little snow-shoes. Two were perfect for mounting, and even the shattered one might, with extra care, be saved. So far, so good. I had killed my own 
specimens and added a new bird to the score of the veteran twelve-gauge.

I pocketed the birds, broke the gun, put in fresh shells, and, on the strength of an easy but clean kill, produced the flask. As Jo took his dose, I noticed his face. Instead of the customary grin, it showed grave and solemn as an owl's. The sparkle of the eye, too, was missing, and when the sight of a drink didn't make Jo's optics gleam, something surely was amiss.

"You foller dem?" he tersely queried, as I made a significant motion. I was somewhat astonished.

"Bad luck kill dem - look dur!"

Something in his voice startled me, and my eyes flashed northward, whither his long arm pointed. Under great stress a man sometimes thinks of whimsical things. What I thought was - "I've killed three pups of the North Pole, and here's the whole frappéd Arctic Circle coming south to see about it!

Rolling steadily down, like snowy surf, mountains high, came a squall the like of which I had never seen. One glance was sufficient. The white mass seemed dense enough for good shoeing, and the way in which its deadly advance blotted out the landscape was absolutely terrifying. Under such a downfall a trail would not show for a minute.

"Come-quick!" said Jo, as he turned, and the gleam in his wild eyes was a solemn warning.

I have run in a snow-shoe steeplechase over rough country, have staggered home, beaten and cooked to a turn, after one of those desperate efforts which foolmen will make for a pewter mug, a cheer, and some 
woman's smile. I have been "butchered to make a Roman holiday" on sliding seat, steel blades, spiked shoon, and other modern refinements, while shrill voices rang and dainty thumbs turned down (they all despise a loser!); I have been guilty of that crime of errors, getting into the "gym" arena with the wrong man, but of all the bucketings ever I got, Jo gave me the worst! Peace to his ashes - he was a scared Indian and he had no better sense!

Only those who have chased a smoke-tanned firewater worshipper on snow-shoes, and about two jumps ahead of a blizzard, can understand. I knew that he knew the trail, and I vowed that if he lost me, it was my fault. All I could see was his dim back rising and falling in mighty effort - then we ran for it in dead earnest. No picking the way no anything but chase - chase - chase. He never hesitated nor slackened, and all the while the snow thickened and the wind shouted louder and louder at the death song. At last, with a roar and a wild horizontal rush of snow, the full strength of the storm struck us. Then we heard the true howl of the White Wolf of the North, as the men in igloos hear it when the sea solidifies. Mercifully it was at our backs, - any other point would have meant but there's cold comfort in that! I knew that if Jo once got out of sight, I might not be found till spring; and winters are long on the North Shore. Besides, I had things to attend to later, - my people to see, and my ptarmigan to mount, - so I chased on. And ever before me was the snowy back, ever in my ears the White Wolf's howl, and in my breast 
the tortured engine pumping to bursting strain. I cursed the hampering clothes and the buttons that seemed ever drawing tighter, the thongs that cut deep now, and the nets that had to be swung true while they felt like lead to the feet.

At last came the blessed "second wind," and none too soon, for it found me rocking. The snow-padded back was ten yards ahead now, rising and falling with the same old motion. Ever and anon a savage swirl would hide it in a blur of white, but I was going easier and felt I could close the gap at will. Presently it vanished, and on the instant of its disappearance I realized my danger and spurted vigorously. Before I had time to think, Jo was again in view, and I mentally vowed that not for my life would I let him out of my sight. Indian-like, he had no idea of halting or looking round to see how I fared. I was to follow - if I failed to do so, that was my affair. When an Indian gets scared, he's the worst scared thing imaginable; and Jo was going to the cabin by the shortest route. If I failed to make it, he'd hunt for me - after the weather cleared.

Through the roar and the whine and the icy fog of it all we pounded ahead. First, an uneasy dread took hold of me. Did Jo know whither he was drifting? Had his instinct for the once failed? We seemed to have covered an awfully long route. Then another and worse fear came, I was getting tired. No mistake about that. No one knew better than their owner why leg muscles were complaining so. One quarter of a mile farther, if we had to do so much, and I'd be done so brown that a bake-oven couldn't tan me more. 
What then? I'd follow the trail as far as I could, then curl up. I had the flask and the infernal ptarmigan, and I'd live on them for two days anyway. But the cold - oh! yes, the cold - well, it would freeze me stiffer than the North Pole in twenty minutes and then - ? The Gray Wolf would come and nuzzle for ears and nose and fingers and they'd snap like icicles and he'd thaw them in his steamy old paunch along with the confounded ptarmigan; but his teeth would click and slip on the flint-hard larger parts and I'd at least have the satisfaction of compelling him to wait for a thaw! The rasp of a twig across my cold nose startled and hurt me so that I roused from the first stage of the deadly, cold-begotten drowsiness, and dimly realized that I was running into cover. The edge of the wood! Yes, and there was Jo's track and Jo himself just ahead.

In ten minutes we were in the cabin. Fifteen minutes later we had got rid of snowy outer garb and had looked upon something hot and oh! so welcome. Presently Jo raised his drawn face from his hands and said:

"Bad to kill dem white snowbird. But you good - run like bull moose - else los'!"

I muttered something - I hate to try remember what, for my eyes were closing in utter weariness.

And even now, when the blizzard ramps among the crowded structures of the great city, the mad white wrath of it reaches a sleeper's ear and - well, the poor little wifey gets up and makes herself some sort of shake-down on the lounge! 


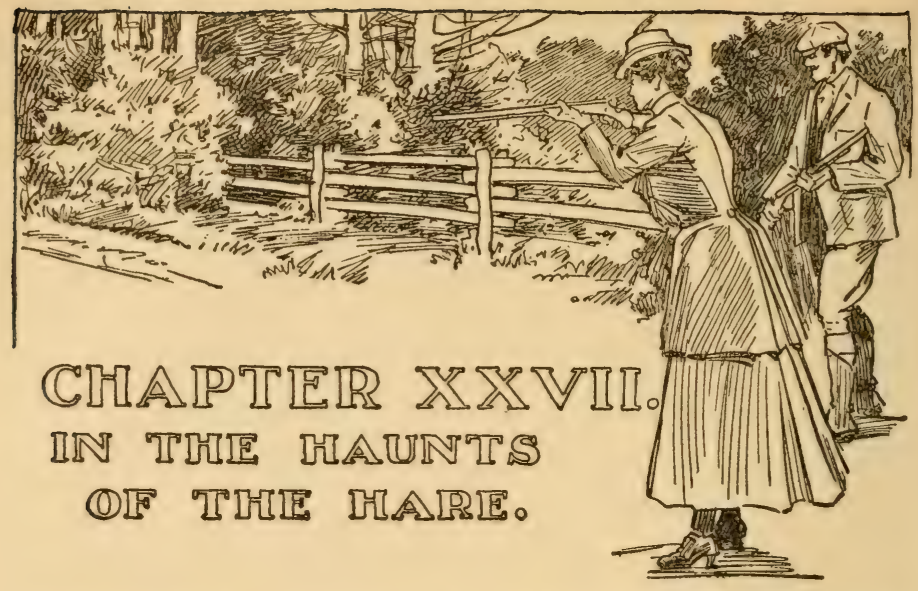

UNDER the general head of "hare hunting" may be grouped several forms of a sport very popular in widely separated parts of the world. To the Briton, the mere mention of a hare calls up memories of coursing and that blue ribbon of the sporting canine world, the Waterloo Cup, which along with other important fixtures has for so long aroused the enthusiasm of our brethren oversea. Several European nations, too, have their own favorite methods of circumventing poor puss, but they need not be dwelt upon.

Until a comparatively recent date, we had nothing to compare with the British sport, but the natural advantages of vast tracts of our Middle West and Far West country were too apparent to be long overlooked after the tide of permanent settlement had once fairly set westward. Among the most useful classes of settlers were sturdy men, and not a few moneyed men, from the sporting counties of Great Britain. These men had the characteristic nomadic and sporting instincts strongly developed - in fact 
the promise of a wholesome freedom and unlimited sport was the magnet which drew many of them to our West - and once there, it is not astonishing that they promptly took advantage of their unequalled opportunity.

The instinct to tackle things which can fight, to pursue things that can run or fly, is absorbed by the Briton with his mother's milk, and one of his dearly loved pastimes is coursing. Hence, he speedily noted the possibilities, so soon as he became acquainted with that weird brute Lepus callotis, commonly termed the "jack-rabbit." This creature can run like the wind; it inhabits the great plains, which afford a clear view and fine footing for horse and hound, so it was only natural that coursing under special rules to suit the new field should follow. How wonderfully this sport has flourished may be learned from a glance over the reports of the many important fixtures annually decided. In its own smaller way, coursing now receives the same close attention as racing. Representatives of the best greyhound blood of Britain are to be found at the head of many kennels, while the breeding, handling, and running of the dogs are in the hands of men as keen and clever as any that ever sent out a winner of the storied blue ribbon. That the sport will continue to flourish goes without saying - the nature of the Western country and the temperament of its people guarantee that. Hawking the "jack-rabbit," too, may yet become one of our most attractive pastimes. I have repeatedly seen both falcons and harriers chase the jacks, and every time the sight called up visions of trained hawks with all the at- 
tendant picturesque and pleasant possibilities. Today, the outdoor woman is queen, and of a surety hawking would give Diana a grand opportunity to spread her conquests further.

The best of our hares is the well-known fellow of the East and North, the northern hare (L. americanus), the so-called "white rabbit." $\mathrm{He}$ is good game in his proper season, and he possesses the great advantage over the "jack" (possibly not from his point of view !) of being also good eating. Child of the snow that he is, he makes his home in the wilds, fearing neither piling drift nor biting blast. He loves the unbroken forest, the snarls of tangled thicket, the twisted wreckage of the tornado's path, the dusk swamps, soundless beneath lonely hills. This hare, like the beautiful ptarmigan, furnishes an interesting example of Nature's loving provision for the welfare and safety of her feebler children of the North. In summer the ptarmigan wears a mottled coat which admirably blends with the prevailing tints of the lichened rocks of its home. Upon the approach of winter the bird's plumage gradually turns white, while a growth of hair-like feathers upon the legs and feet thickens until it forms the snowshoe foot - the best possible thing to support the bird upon snow and to protect the feet from frost. The hare, lacking wings, requires better protection, and Nature attends to it. During summer, the prevailing color of the coat is a grayish brown, the most inconspicuous of tints among roots, rocks, shrubs, and the various surroundings of the breeding season. The hare's special gifts, without which he would speedily succumb to various foes, including 
climate, are those four valuable F's - foot, form, fleetness, and fur.

Each and all of these are unquestionably most useful at times, but when snow lies deep and loose, the winning trump is the peculiar foot. In winter this becomes a veritable snow-shoe, a truly marvellous contrivance which enables the comparatively light animal to patter at will over drift and level which would otherwise hold him fast, a helpless prey to rapacious beast or bird that chose to attack. Nothing better for their purpose than his furry pads can be found among Nature's many marvels. His coat, too, plays an important part. Thin and cool during the heated term, as the cold weather approaches it thickens apace until it forms one of the lightest and warmest of coverings. The wild men of the North were quick to appreciate its valuable features, and wove strips of it into the cosiest of wraps. But the warmth and lightness of the coat are not all of its peculiarities. Grayish brown upon snow would be entirely too conspicuous, so Nature meets the difficulty with another beautiful provision. As the coat thickens as a guard against cold, it gradually turns white to match the increasing snow. The brown pales to a cream, and the cream whitens till only a darkish stripe down the springy back, and patches about the big eyes, remain to tell of the summer garb. Soon these too fade, until the hare is pure white, or so nearly so that he can squat amid the snow and so closely match his surroundings as to escape even practised eyes. If by chance discovered, he can speed away upon his snow-shoes and in a few bounds vanish in the snowy woods, where every log 
and stump is a perfect cover. This is well, for in addition to man he has natural foes which know not mercy. Chief among these are the lynx, fox, wolf, fisher, marten, the great horned and the snowy owls, and other rapacious birds. Other creatures, too, prey upon him more or less at their murderous wills, for if once cornered, he offers no defence whatever.

Most of the hares which not seldom glut our winter markets are victims of the snare. A few are trapped in other ways, while others are shot, but their numbers are insignificant in comparison to those which die by the craftily placed wire. To snare a hare is, of course, an unpardonable thing from a sportsman's point of view. The habits of the animal render it such an easy victim that only a thoughtless boy, or an out-and-out poacher, would bother himself over its capture. Like the Virginia deer, the hare has regular runways along which it travels through its favorite swamp or other cover. All the poacher has to do is to locate these runways by the tracks, set a few snares, and wait for the unfortunate hares to do the rest. The snares are fastened to "twitch-ups" - springy poles, sufficiently long and strong to lift a hare a few feet off the ground. The wretched victim sooner or later comes hopping along the runway, his head enters the noose, and in an instant he is jerked off his feet, then hanged by the neck until he is dead. The object of the spring-pole is twofold - first, to strangle the victim, and second, to lift the body beyond the reach of any prowling creature which might fancy cold hare. The whole business requires about as much 
skill and is about as keenly exciting as the purchase of a frozen hare from a city dealer.

The sport of sports with the hare is to shoot him ahead of smart hounds, but there is another way, and I have followed it of a winter's day with considerable pleasure. It is still-hunting, in other words tracking the hare to his "form" and shooting him as he bolts. The man who craves rapid action in his sport may smile at this, yet I have found fun, much opportunity for interesting observation, and a lot of healthful exercise in it. A still, bright day after a snowfall is the best. Then all tracks are fresh and all woodlife, housed during the storm, is active. To the experienced sportsman the work is comparatively easy, for the trained eye sees the country as one great white page with a series of short stories - some pathetic, many tragic, but all interesting.

A leisurely start is as good as any, for wild life sleeps late these white mornings. So somewhere about nine o'clock I strike across the broad level of a farm toward the gray ring of woodland. There is walking to be done, and the costume is well chosen. First, medium-weight, all-wool underwear and warm, home-knit socks. Over this a suit of gray corduroy, the trousers being roomy to the knee, thence fitting like drawers to the ankle, where they are tied with soft tape. Three smoked-pearl buttons at the knee give the appearance of knee-breeches. The gray sweater and coat give necessary warmth and pocketroom. The hat is corduroy. The boots are waterproof tan, lacing to the knee. This costume is neat, workmanlike, and very comfortable. It would look businesslike on top of a good horse, and it is first- 
rate for tramping in snow. The gun is a hard-shooting, featherweight, modern arm - a killer such as our fathers never dreamed of. The dozen or so little shells go into one pocket, sandwiches into a second, pipe and "baccy" into a third, while the smallest of flasks of ginger wine fits over the hip, the outfit being admirably adapted to what may later prove a long and cold tramp.

The man who still-hunts a hare must be a good walker and one of those favored few who do not measure their pleasure by the amount of game bagged. The time for the sport is after the regular shooting season, and while it has joys all its own, it does not appeal to men who want to be forever pulling trigger. From three to a half-dozen hares would mean a good day with a most liberal allowance of honest tramping.

A mile across country settles breakfast famously, and as I reach the edge of a low-lying patch of maple thicket, I feel in fine fettle. There are perhaps one hundred acres of good ground where hares are known to be, so I tramp along reading the snow-page's morning news as I go. There are many local paragraphs, all of more or less interest. "Mr. and Mrs. Fox Sparrow and family have taken that snug cottage, 'The Briers,' for the winter." "The Messrs. Chickadee, Woodpecker, and Nuthatch are in our midst. They are expert prospectors and confidently expect some rich finds. They are at present exploring the big swale." "There was an unseemly row at a dance last night, which might have ended seriously if our esteemed night-watchman, Mr. G. H. Owl, had not arrived in the nick of time. 
Mr. Owl, always prompt and efficient, at once arrested the notorious Molly Cottontail and haled her before the Beak. She was promptly put away." "Householders are warned that the well-known criminal, Brown Mink, is hanging about the neighborhood. Our readers will do well to closely examine all fastenings before retiring." And so they ran on in the usual backwoods style.

To take it seriously, though, this reading of the snow is a wonderfully interesting thing. Here the delicate tracery of tiny feet tells where the seedladen ragweed bent low. Yonder a regular stitching and a tiny furrow betray the feet and dragging tail of a wood-mouse; again, a series of small prints marks the course of a red squirrel to and from his hidden granary. Trim, close-crowded marks tell where a bevy of Bob Whites followed the zigzag shelter of a rail fence. At the edge of the swale, a single row of round, evenly spaced prints marks the route of a fox, and farther on the sign tells that he tried for a grouse and missed. All the doings of day and night are truly recorded, and he who loves the wild things and their affairs may be pardoned for lingering over this, his morning paper.

At last I find something which directly concerns present business. It is a rough triangle - the apex two small prints, the sides two long ones. It is the track of a hare, and the distance between the prints proves he was going at speed. A green hand almost certainly would follow the back track. When a succession of big V's indicate a route, the eye naturally follows the way the points direct. In this case, that would be an error. I have a vivid recollection of the 
first time I followed a hare's track. It led across an open to a big brush-pile, under which it ended. All about was virgin snow. That the hare was as good as mine I never doubted, so I kicked the pile. Nothing showing, I mounted the pile and jumped on it till it rocked to its base. Still nothing appeared. Somewhat mystified, I began to remove the brush, a branch at a time. This, with the gun in one hand, was slow work, and every time a lump of snow would shift I'd spring back and bring the gun to shoulder, for I knew that hare would go like all outdoors when it did go. When I got down to the bottom of that brush-pile, and found only the spot where a hare had lain up, I was mad and wise all through.

But to return to the trail. The track told its story. The maker of it had been going fast, but as there was no following track, the hare, presumably, had been bent upon urgent private affairs, and might or might not be anywhere within a circle of one hundred yards' diameter. The thing to do was to follow the trail and find out. Now, following the trail of a hare through heavy cover is no joke. He may have visited every outpost of the swamp during the previous night, and again he may not have travelled a quarter of a mile all told. In either event, one moves as though still-hunting deer, ever sticking to the track and keeping a sharp lookout in front. When the hare moves, it will be with an easy leap from some shelter, followed by a rush through the cover which carries the quarry from sight with an astounding celerity. So the gun must be ready for rapid action. As a rule the hare will be squatting under a brush-pile, log, or fallen top, 
but quite frequently a cleft between roots, or the interior of a hollow stump, forms the hiding-place. It is odds on that the hare sees its pursuer before being discovered, hence it is as apt to start from almost under one's foot, or behind one's heels, as anywhere else. All wild creatures, when hiding, appear to know the instant they are detected, whereupon they immediately make off. I have more than once walked almost over a crouching hare, only to start it when I turned to look for the lost track. Needless to say, it is very seldom the white fur is seen amid the snow before the creature moves. When it finally does start, one may be astride of a big log, or snarled up in some brush, or in any one of a dozen possible difficulties which may interfere with the necessary quick, sure shot. As a rule, however, one sees a hazily defined, speeding shape, and either bowls puss over there and then, or realizes the force of that ancient warning - "First catch your hare." This sort of still-hunting may lead into all imaginable forms of bad going - through brush, where dislodged snow is forever falling; through thorny stuff which never seems to weary of raking one's face and hands; and, worst of all, across ponds of unknown depth, the icy covering of which may or may not bear a man's weight. It is, therefore, well to be a bit shy of nice, open levels, which offer the easiest of walking. They are very apt to mean ice and more or less water. To a lone trailer a ducking in the woods is no joke, and it may prove quite a serious matter; for, as a general thing, getting in is a heap easier than getting out.

So much for the still-hunting. It may be that 
the track must be followed through half a hundred twists and doublings, which in all demand more than a mile of trailing. It may be that the hare, missed at the first chance, must be again trailed to wherever it chooses to stop. If so, there is a fresh track and a hare at the lost end of it; and patience will bag that hare. I am free to confess that I like the silent prowling, the keen watching, the side glimpses of other small life, and that smack of the long agony of hope deferred, which are sure to be the portion of the still-hunter.

Hounding hare is quite another matter. It has its share of action, its sweet bells jangled out of tune, of dog-voices, its tense situations, and, upon good days, its sufficiency of quick, accurate shooting. It has another advantage, too; our modern Diana may share it, an she be so graciously disposed. For instance:-

"Ed, you've just got to take me! I'm smothered - I want to get outdoors - I'm ready - I'll drive -I'll do anything! and "- here the voice buzzed like a yellow-jacket - " if you don't take me, you shan't have my dog — so there!"

"All right, my gentle guinea-hen. That tongue of yours would be a grand thing on a cold trail it's a cursed shame you didn't get four legs when they were passed round - I'd take you sure, then," I retorted.

"You're just the dearest old thing in all the-" she began, but I cut it short with -

"That'll do now! - get your hooks out of my gray hairs and let me be. I've got my opinion of young women who get dressed all ready before they 
ask if they're wanted. I don't want thee, sweet cousin, but I do need thy dog!"

Reader, especially female reader, don't raise your eyebrows and sniff. The young woman is a spoiled pet, that's all. Anyway, I'm old enough to be her father, and I taught her to shoot. During some paretic interval I gave her my one rabbit-dog, an overgrown beagle, by name "Boz," and a rare good one. Later I tried to beg him back and was sent to Coventry for a period of one week. So there you are.

Within half an hour nag and sleigh were ready, and away we went. There was just enough snow for good slipping, and cousin's small hands kept the nag at his best pace until she pulled him up at a farm-house some five miles from the starting-point.

As we tramped toward the chosen ground, - a big, almost impenetrable swamp surrounded by woods, she led the way. I looked her over and she was good to see. The gray "Fedora," with its grouse's plume, closely matched the sweater, easy-fitting cord coat, and short skirt. She was a symphony in gray, with which the stout, oil-tanned boots and scrap of dull crimson ribbon had no quarrel. Very feminine, also foxy, was that wholly unnecessary scrap of ribbon. Two autumns before we had chanced upon a beauteous thing - a great frond of crimson sumach draping a mole-gray, mossy rail. That combination I had worshipped there and then, and - well, she being a woman, etc. Easy in every movement, she swung along with a businesslike stride which would tire many a man, and as I watched I thought with pleasure of the thousands 
of other girls of the rational school - the mothers yet to be of a sturdy race, which, so long as it sticks to the grand outdoors, will never lose its AngloSaxon might. The gun upon her shoulder was as a featherweight to that lithe, graceful figure, a toy to the strong, small hands and firmly muscled arms.

Where an old road traversed the swamp were our vantage-points, and we took stands some fifty yards apart. Boz had needed no instructions - he was already somewhere in the cover searching for a fresh track. Lil brushed the snow from a log, rested her gun against a sapling, and sat down; I filled my pipe and stood peering into the heavy brush. For perhaps twenty minutes we waited, then a single sharp bark came to us. Lil's clear soprano answered with a cheery, far-reaching cry, then the dog barked again. This was his signal that he had located some trail worth following. Presently there rose a sudden storm of music - a confusion of doglanguage, as though a dozen canine tongues had been loosed together; then abrupt silence.

"Look out - he's started!" I called, and the gray figure straightened up, gun in hand. For a few seconds we listened in vain, then came the welcome message. Like the Switzer's call it clove the snowy aisles of silence until the forest rang with sweetest melody. Louder and clearer it swelled, till one might well marvel that one small dog's throat could cause it all. Then it muffled as he swept through some hollow, only to rise and ring like a bell that flings good news to a waiting host. It was evident that Boz had got well away with his game and was driving at top speed. A long cir- 
cling, a period of doubt, and then a rapid, insistent tonguing, steadily increasing in power, told that the quarry had decided to cross the road.

And now the thrilling moment of hare shooting. The animal might take the road for a distance, but in all probability it would burst, like a puff of winddriven snow, from the cover, take two long leaps in the open, then dive into the opposite cover with all the headlong abandon of a big frog going to water. Sharp work this, for there's no telling how close behind the dog may be.

We were both at the ready as need demanded. A roar from the dog told that for an instant he had sighted, then a long, white shape curved from the brush to the road and rose again with rubbery ease. Smooth, silent, swift as it was, the girl's trained muscles beat it. I whirled about and humped my back, for small shot stingeth like an adder, and even a glancing pellet is bad for one's eye. As I dodged, my ear caught the quick, vicious squingesquinge of the lightly charged shells, followed by a ringing note. No mistaking the triumph vibrant through that call - the small hands, the keen young eyes, had done the trick, and the old fool-teacher felt prouder than if he had done it.

Mutely eager, the dog flung himself across the trail to make sure, then his sickle tail waved slowly and proudly as he paused and snorted gruffly over something in the snow.

"Did I miss him ?" shrilled an anxious voice.

Up went the dog's nose, and he jangled out his version of - "We - killed - the - hare!"

"All right," I said as I picked up the fat fellow 
and drew the long body through my gripping left hand - a stripping process that is good for dead hares. His ears looked like the top of a peppercaster, and I gloried in the swift, clean work. Then I carried the prize to the radiant owner.

Rail against it if you must, $\mathrm{O}$ prudes, but I believe in any rational sport which can kindle the spark of triumph in a woman's eye and send the rich red of pure delight to her cheek. As I looked at her and heard her ecstatic " My, he's a fine fat fellow!" it did seem that any decent buck rabbit ought to welcome annihilation from such a source. Being a man, and just naturally more or less of a brute, all I said was -

"Awfully sorry, coz, but I couldn't help shooting ahead of you - weren't you a trifle slow?"

She looked me squarely in the eye for what felt like an hour, then the words came like the final hammer-raps on a rivet -

"Y-o-u b-r-u-t-e! And you standing there with your back humped and everything pulled in like an old mud-turtle, when I wasn't holding within ten yards of you!" 


\section{CILAPTIER XXXVIII.}

FISUING TIRIOUGI

TIUIE ICEE。

A shining February morning and a great white, shining world - white as the soul of a child! Over it all an infinity of flawless blue, with never a token to prove that from it fell, but a few hours before, the world's fair garb of snow. Eastward blazed that gold-faced god who makes a typical winter day the wondrous, indescribable thing it is.

It was cold outside, and I knew it. My argument with a devilled kidney had been interrupted more than once by sharp reports like pistol-shots, which told that the frost had touched a tree, or started a nail in the clapboards. When the kidney had acknowledged getting the worst of it, moccasins, heavy pea-jacket, fur cap, warm gloves, were donned, and forth I fared to find what such a peerless day had in store. The air was keen as Eastern lance and glittered with myriad diamond lights; it was as exhilarating as iced wine, and three chestfuls of it started me running down the snowy road in sheer exuberance of animal spirits. Presently a merry jingle of bells sounded and a merrier voice exclaimed, "Look out! or I'll run you down."

No need to look round, for I knew the voice; so I merely answered, "You couldn't run a lame dog down with that old skate!" Then I ran as if the 
fiend was on my track, for a four-minute bay roadster and a dainty Portland were behind, and Jim would as soon do what he said as not.

For a hundred yards we had it hot as we could lay foot to snow; then I heard the dull blows of flying feet and a sharp " Hi!" and dodged aside just in time to clear the rush of one of the tidiest gentleman's roadsters in the country.

Jim could hardly pull up inside of fifty yards, for the good bay's blood was hot; but finally the horse steadied, and Jim sung out: "Come, pile in here! I want to use you."

"What for?"

"I'm off for the bay. Spearing's prime, and we'll have a try at it. Everything's ready down there spears and all in the shanty - so in you get."

No better fun was wanted, and away we jingled through the town and thence westward over an excellent country road toward Mitchell's Bay, on Lake St. Clair, famous for black bass, 'lunge, and waterfowl since the days of "Frank Forester."

Mile after mile our game horse flung behind, now passing fat farms - great levels of white-now waking the echoes of dense, shadowy woods with the crisp jingle of the bells, until at last we reached the frozen marsh and the small hotel beside the bay.

Very brief time sufficed for final arrangements, and we were soon in our shanty, one of several similar in construction that were scattered over the ice. These shanties are built of rough boards and are large enough to accommodate two men and leave room for a small stove. The roofs are high enough to allow the use of a short-handled spear, and fre- 
quently the shanties are mounted upon runners of plank to facilitate moving from point to point. It is comfortable and dark inside a shanty when once the door is shut, for there is no window, the object being to exclude all light save what strays upward through the clear ice-floor.

When a shanty is ready for business, it is stationed on the ice above some known shoal or channel favored of fish; a little snow is banked up around the house and an opening of convenient size cut through the ice inside. This hole is carefully cleared of all fragments of ice, and when the shanty door is closed, one can peer down into the haunts of fish.

The grandest prize to fall to the spearman's skill is, of course, a "'lunge," as the mascalonge is termed, and to attract his lordship within striking distance, an artificial minnow is attached to a string and caused to play about a short distance below the surface of the exposed water. When a fish of goodly size shows within safe reach, a swift thrust with the three, four, or sometimes five tined spear secures or misses the game, as the case may be.

Jim and I sat side by side, gazing downward. I manipulated the minnow, while he held the spear ready for instant action. Below were soft, shadowy, green depths, half-illumined by a weird, ghostly light which seemed to come from nowhere and to reveal nothing. But soon our eyes seemed to focus properly, as it were, and the view broadened. We could distinguish faint forms of water-weeds, and once or twice a gilded perch sailed solemnly across the silence below, like a seared leaf wind driven.

It was very pretty and fascinating, and I swam 
the lure minnow in most artistic style for a considerable time. Then something came! It came, it saw, it vanished, leaving a phosphorescent gleam in the water to mark its lightning flight. I had barely time to note that it was a sturdy old bass, and Jim's hand hardly closed on the spear ere it had gained the dim whence. It evidently wanted naught of the minnow or spear.

More time passed, and then came a pickerel. Slow and shining, he floated upward, his wall-eyes glowing on the fancied prey, and Jim poked fun into him vigorously; and the pointed joke was too much for pickerel self-control, and he let his life slip away in his excitement. Three or four more were taken in the same fashion within the hour, and they were all fine fish of their kind. Then Jim insisted that. I should take the spear and let him play the lure.

For half an hour I sat and stared at the water. Then I yawned and filled my pipe anew, and then it may be that I fretted at the hard luck on general principles. Be that as it may, I presently spied something which roused all the fierce impulse of sport in me. Jim saw it, too, and he played his minnow a trifle farther away.

From under the lower edge of the ice crept something that looked for all the world like the toe of an old rubber boot, surrounded by a luminous halo. Farther and farther it crept, so slowly that it seemed scarce to move, until it showed a greener cast and bony ridges. Then the gleam in the water increased, and we saw two terrible eyes that glowed like wee incandescent lamps. Then Jim suddenly lowered 


\section{Fisbing through the Ice}

his minnow a few inches, the apparition glided forward, and I drove the spear downward with all the force and speed my arm could impart. Through the wooden handle I felt the crush and grind of steel through bones, and knew 'twas well. The shaft swept round in response to a failing, swirling rush, and we promptly lifted from the hole a dead fish, for the spear had cut the spine just at the junction with the head. The fish was by no means as heavy as many I have seen, but it was large enough for our ambition, and, best of all, we had it safe.

That was spearing as it is apt to average upon those lucky days when everything works just right, but not seldom there are trifling mishaps and once in a long while a truly perilous experience.

One sunny morning two of us snapped skates to boots and started for the bay, where fifty or more Frenchmen made a business of winter spearing. We anticipated great results. But we had a long distance to skate, and did not reach our shanty before noon.

The big frog-eater in charge greeted us warmly and said: "Oui, dis grate day; but you should bin here before. Mebbe vataire milky 'fore long."

We didn't care a continental whether the water might get "milky," and in brief time the Frenchman left us alone. When we first shut ourselves in our little cabin, everything appeared black as tar, but gradually our eyes grew accustomed to the strange half-light from ice and water. My comrade first took the spear, while I worked the decoy-minnow. A board formed a seat, and we sat side by side, he 
with the spear ready and I holding the decoy string, which I manipulated in such a way as to cause the "minnow" to waver about, so that fish far below could see the lure. We could see far down into what was apparently bottomless green space. A submarine jungle of streaming, brownish weeds spread afar in every direction; dim, shadowy caverns and corridors showed faintly, and now and then a glint of silvery light or a ghostly shadow seemed to drift through them. I worked the minnow zealously for nearly an hour, and at last something came rising solemnly toward us. Just as I made out a pair of glowing eyes, the spear shot viciously downward and we had what proved to be a pickerel. It was a goodsized fish and we felt encouraged. The next wait was very brief. A big form flashed into view, hesitated an instant, then vanished like lightning. The spear made an impotent thrust, seconds too late, and the spearman's voice exclaimed: "Gee! what was it?" "It was a big bass, you chump, and you let it get away!" was my polite reply. Presently another fine pickerel rose and was secured, and it was followed by two others. Still I waggled the decoy and the spearman remarked, "This is great!" Then he changed his position so that one of his boots projected half its length over the hole. Neither of us noticed it at the time, for we were intently watching something more interesting. Down below was a half-defined shape - a 'lunge, and a whacker in comparison to the victims we had speared. For seconds it rose so slowly that we could hardly see it move; then it gave an unexpected dart and came right into the hole. The suddenness of its rush 


\section{Fisbing through the Ice}

rattled the spearman and he made a fierce random jab. A yell, a splash, some sultry talk, and he pulled his soaked leg out of the hole and limped grunting about on the ice, while I secured the spear and remarked, "Well, you are a clever duck!"

"I druv the blank thing into me foot," he howled; and, sure enough, he had punched a hole through boot and skin. When I got the spear and tried to see below, I found matters had changed. The erstwhile transparent water seemed whitish, and soon I could see naught but the soapy-looking surface.

A thump at the door and a voice outside saying, "Vataire got milky; dere no more feesh to-day!" warned us that the fun was over. As we snapped on our skates, the unlucky one whispered: "You tell about my foot an' I'll make it hot for you!" This is the first I've said about it.

The fishing with hook and line is sportsmanlike enough to qualify as a legitimate amusement, and is by far the most popular with the good souls and true who love an outing for its own sake, and would take fish, or take cold, with pleasure, providing a certain amount of fun was attached to the business.

In this method of winter fishing, baited hooks, attached to lines of suitable length, are passed through small holes cut in the ice, the upper ends of the lines being either held in the hands of the fisherman, or affixed to what are termed "tip-ups." When these tip-ups are used, they allow one man to attend to as many lines as he pleases, and to skate or slide about, or watch the indicators from beside a bonfire or from a warm shanty, as may be preferred.

There are various styles of tip-ups. Some are so 
constructed as to actually tip over when a fish bites, hence the name; while others are simply uprights of lath or light stuff a couple of feet long, to the upper ends of which are attached arms of wood which pivot easily upon a nail or screw. The preparations for the fishing are few and readily completed. With tip-ups properly constructed, the fisherman seeks frozen lake or stream, and with small axe or chisel cuts the requisite number of holes through the ice and carefully removes all floating fragments to prevent the orifices coating over rapidly in a biting atmosphere. Close to each of these holes a deep niche is cut in the ice, and in this the armless end of a tip-up is set and firmly tamped with chopped ice or snow. A small quantity of water is then splashed or poured upon the tamping, which speedily solidifies and holds the tip-up firmly. When all the tip-ups are in position, the tackle is put in place.

A hook is baited, generally with a bit of pork fat or bacon rind, and dropped through one of the holes; a turn of the line is taken around the free end of the movable arm, and the end of the line brought down the upright and tied fast close to the ice. This reduces the leverage when a fish pulls, and prevents the tip-up from being dragged from its moorings. When the lines are set, the last operation is to see that all the movable arms are vertical and in true line with the uprights. When a fish pulls at the bait below, the arm of the tip-up yields, its free end pointing toward the hole in the ice and signalling that a quarry of some kind has tampered with the bait. Then the fisherman makes all speed 
to the spot and hauls up the struggling captive. Frequently, when a number of lines are set and the fish are biting freely, two or more tip-ups will signal at the same time. Then the fisherman rushes from one to another in mad haste and there is fun galore, especially if the ice happens to be smooth and the owner of the tip-ups does not have skates.

I have seen a long row of these lines set on a lake and a party of half-a-dozen dignified business men watching them from the shelter of a fish shanty. One or more wooden arms would dip, and lo! an avalanche of excited mortals would burst through the doorway like a parcel of boys from school, and speed across the treacherous surface - running, slipping, sliding, falling, and whooping and yelling in wild delight, till the tip-ups were reached and the prizes secured. Those stately old kings of commerce were more or less gray-headed, and maybe a bit austere when at home, but they were just frostywhiskered boys when the tip-ups signalled. Next day they were doubtless stiff as to muscles, and black and blue in spots where the ice hit them; but they had enjoyed uproarious, healthful fun, freed their minds for the time of all worry, filled their lungs with air that made them new men, and, best of all, they had laughed the laugh that does men good - the laugh of pure, clean mirth.

Exciting and hilarious as this sport generally is, it sometimes ends in trouble, or at least a thorough scare for its laughing votaries. The element of danger enters into it under certain conditions, and it is not alone the possibility of an unexpected ducking when some careless person finds an unsuspected 
weak spot in the ice. One such experience will illustrate the possibilities. Half a dozen of us formed a fishing party and skated down the Thames River to Lake St. Clair, intent upon trying the tip-ups.

It was a long skate, but a stiff breeze was at our backs and we spun along famously. In due time we reached the lake and found that a floe of shore-ice extended outward for perhaps something over a mile. Beyond its further limit gleamed an expanse of heaving, ice-cold billows. In brief time we had knocked the snow off a goodly supply of driftwood and built a roaring bonfire. Then we skated some distance out upon the ice over a well-known shallow and rigged the tip-ups. Fish were not in good biting humor, and victims were caught but slowly. After an hour or so of rather tame sport we got careless and skated hither and thither, frequently visiting the fire and occasionally dashing for the tip-ups at racing speed when a strike was indicated. It was fun of its kind, and we fooled away time, hoping the wind, which was against our homeward trip, would either moderate or change. At last, for some unknown reason, one of the crowd skated far out toward open water, and after yelling in vain for him to return, we all straggled along after him, letting the wind blow us as it pleased.

We had got within about fifty yards of him, when he suddenly swerved in his course and faced about, made a few hasty strokes, and halted. We guessed that he had reached dangerous ice; so we scattered to spread our weight over a broader surface and leisurely slowed up.

Suddenly he pointed for the shore, and with a 
yell darted ahead at his topmost speed. Every man guessed what he meant, and, like so many horses at score, we wheeled and broke away with him as he flashed past. It was well that we did. All eyes turned toward our fire, and we knew that our work was cut out for us. Halfway between our position and the shore a long line of white spray was splashing above the ice, and we knew that the floe had parted and was drifting.

It was a hard drive against the wind, and for half a minute or more the steel blades rang in furious cadence. The head man marked the narrowest place in the broadening fissure, and shouting, "Jump! Swim! Get there!" swerved a trifle and shot at it. He rose like a steeplechaser, cleared a seven-foot crack, and landed fair and true. Rip-zip - rip-zip! an instant's scared glance at the increasing space, and one after another we set our teeth and raced down to the take-off and leaped as we had never leaped before. Two fell on landing, but all got over dry and safe, though with quivering muscles and thumping hearts. It was an extremely close thing, and next morning that parted floe was piled in small fragments by a furious gale somewhere about the mouth of the grand Detroit River, miles to the westward.

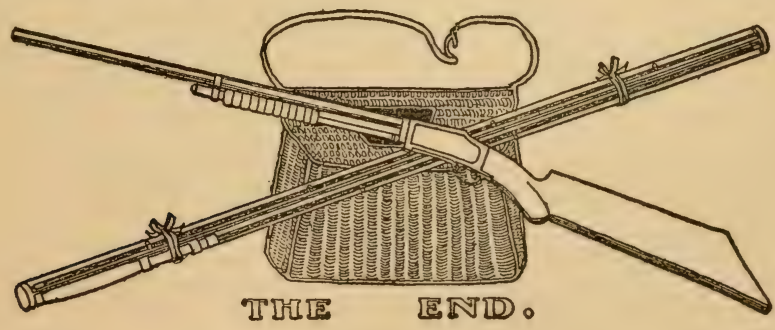





\section{SPORTSMAN “JOE"}

By EDWYN SANDYS

Author of "Upland Game Birds," "Trapper ' Jim," etc.

With Illustrations by J. M. GleEson and C. W. PANCOAST

Cloth $\quad 12 \mathrm{mo} \quad \$ 1.50$

"We feel a sincere sympathy for the sportsman, young or old, who has not known the pleasure of following Edwyn Sandys' 'Trapper Jim' and 'Sportsman Joe,' each in their separate and varied careers, through some $35^{\circ}$ pages of about the most fascinating literature imaginable. Besides being human interest stories, these two books are veritable storehouses of accurate sportsman lore, so skilfully inserted as to impress this knowledge indelibly on the retina of the mind without in even the smallest measure sacrificing the interest." - N. Y. American.

\section{TRAPPER “JIM"}

By EDWYN SANDYS

Author of "Upland Game Birds," etc.

With illustrations from photographs, drawings, and diagrams

Cloth $\quad 12 \mathrm{mo} \quad \$ 1.50$

"A book for every up-to-date boy, not only because he will thoroughly enjoy it, and learn much from it, but also because it will make him more manly." - Boston Transcript.

"Sufficient to gain for him the friendship of all live boys who read it; . . so interesting that the average boy will throw away a story of Indians or detectives to read it." - The Reader.

"A kind of holiday in itself. It feeds the hungry imagination. ... The boy who cannot feast upon this provision, deliciously presented, ought to ask the doctor to look at his tongue." - The Watchman.

\section{THE MACMILLAN COMPANY}

\section{4-66 FIFTH AVENUE, NEW YORK}




\section{UPLAND GAME BIRDS}

By EDWYN SANDYS and T. S. VAN DYKE

With numerous illustrations by L. A. FUertes, A. B. Frost, J. O. NUGent, and C. L. BulL

Cloth Crown 8vo \$2.00 net

"It is a creditable work, written with care and intelligence, and will be found very entertaining by those who pursue feathered game. There is a good deal of instruction to be found in the work, which is likely to add considerably to the success of the sportsman when hunting the birds described."

- Shooting and Fishing.

\section{THE STILL HUNTER}

\section{BY THEODORE S. VAN DYKE}

With numerous illustrations by CARL RUNGIUS and the Author
Cloth
Crown 8vo
$\$ 1.75$ net

"A vivid account of the most exciting sport in the world. It is the record of years of experience under the old circumstances, of years of hunting when the game was so shy that only craft almost or nearly equal to that of the quarry itself was necessary for a successful shot. It is crammed full of valuable advice for the deer hunter, and it has the advantage of having been written before hunting became more of a pastime than a serious business, requiring untiring energy, great patience, cool nerves, and perfect sight."

- Chicago Tribune.

\section{THE MACMILLAN COMPANY}

\section{4-66 FIFTH AVENUE, NEW YORK}




\section{The American Sportsman's Library}

Under the general editorship of CASPAR WHITNEY, editor of Outing

Cloth Grown 8vo \$2.00 net each

EACH VOLUME PROFUSELY ILLUSTRATED

THE DEER FAMILY

By Theodore Roosevelt, T. S. Van Dyke, D. G. ElliotT, and A. J. STONE

SALMON AND TROUT

By Dean Sage, W. C. HaRris, H. M. Smith, and C. H. Townsend UPLAND GAME BIRDS

By EDWYN SANDYS and T. S. VAN DYKE

THE WATER-FOWL FAMILY

By L. C. SANFORD, L. B. BISHOP, and T. S. VAN DYKE

BASS, PIKE, PERCH, AND OTHERS

By J. A. HENSHALL

THE BIG GAME FISHES OF THE UNITED STATES

By CHARLES F. HOLDER

MUSK-OX, BISON, SHEEP, AND GOAT

By CASPAR Whitney, George B. GrinNell, and OWen Wister GUNS, AMMUNITION, AND TACKLE

By Capt. A. W. Money, Horace Kephart, W. E. Carlin, A. L. A. HimMELWRIGHT, and J. HARRINGTON KEENE

THE SPORTING DOG

By JOSEPH A. GRAHAM

AMERICAN YACHTING

By W. B. STEPHENS

LAWN TENNIS AND LACROSSE

By J. PARMLY PARET and Dr. W. H. MADDREN

THE TROTTING AND THE PACING HORSE

By HaMilton BusbeY

THE AMERICAN THOROUGHBRED

By Charles E. TREvathaN

RIDING AND DRIVING

By Edward L. ANDERSON and Price Collier

PHOTOGRAPHY FOR THE SPORTSMAN NATURALIST

By L. W. BROWNELL

In Preparation for Early Issue:

THE BEAR FAMILY

COUGAR, WILD-CAT, WOLF, AND FOX

ROWING AND TRACK ATHLETICS

BASEBALL AND FOOTBALL

SKATING, HOCKEY, AND SKATE SAILING

THE MACMILLAN COMPANY

64-66 FIFTH AVENUE, NEW YORK 




SEP 5 ? 190: 



LIBRARY OF CONGRESS

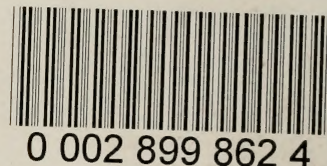

